\title{
ANDRÉA LUIZE
}

\section{O PROCESSO DE APROPRIAÇÃO DA ESCRITA NA INFÂNCIA: SITUAÇÕES INTERATIVAS NA PRODUÇÃO TEXTUAL}

Dissertação apresentada à Faculdade de Educação da Universidade de São Paulo para obtenção do grau de Mestre em Educação.

Área de Concentração: Linguagem e Educação

Orientadora: Prof ${ }^{\mathrm{a}}$ Dr $^{\mathrm{a}}$ Silvia de Mattos Gasparian Colello 
Ao meu marido è à minha filha, com amor. 


\section{AGRADECIMENTOS}

Agradeço de modo carinhoso a minha orientadora, Prof ${ }^{a}$ Dr $^{a}$ Silvia de Mattos Gasparian Colello, pela paciência e sabedoria com as quais me acompanhou nesses três anos. Muito mais do que orientadora, uma interlocutora. Muito mais do que interlocutora, uma mestra. Muito mais do que mestra, parceira e amiga eterna.

À Lucinha Magalhães, minha primeira e grande mestra no mundo da Educação, por me apresentar com magia o universo maravilhoso da linguagem e da alfabetização!

À Sonia Barreira, pelo convite inesperado e pelo susto em forma de desafio que me abriram as portas para o mundo da pesquisa. Não fossem esses estímulos iniciais, essa dissertação não ganharia vida.

À equipe de profissionais da Escola da Vila e, em especial, a Vânia Marincek e Zélia Cavalcanti, pelo incentivo de sempre e pela confiança que depositam em mim.

Às professoras Leila Monteiro e Teca Antunes pela ajuda, paciência e generosidade com as quais me confiaram seus pequenos alunos.

À Iara Bárbaro, pelo auxílio ilimitado com as questões tecnológicas.

À Gunga Castro, com imenso carinho, por tudo o que me ensinou como parceira de trabalho e de estudos (regados a “Ana Maria”!), pelo apoio irrestrito e, sobretudo, pela amizade absolutamente incondicional.

Às maravilhosas, únicas, especiais e queridas amigas, Érica de Faria, Priscila Sbizera Bolognesi e Susana Aguirre (em ordem alfabética, pois são todas igualmente parte essencial da minha vida!), pela paciência e pelo apoio principalmente em meus momentos de desânimo e de cansaço, pela rica parceria de trabalho ou de estudos e pela disponibilidade generosa em partilhar, tantas vezes, os seus e os meus escritos.

Às colegas, "mulheres maravilhosas” do GEAL - Grupo de Estudos e Pesquisa sobre Alfabetização e Letramento -, pelas imensas contribuições em forma de discussões (por vezes construtivamente acirradas!), de dicas de leitura e sugestões de estudos.

À minha “pequena grande” família, pelo carinho e apoio sem limites!

Aos "pequenos grandes estudantes” que, com paciência e disponibilidade, participaram das situações de investigação e enfrentaram os desafios da escrita com a maestria singular da sabedoria infantil. 


\section{SUMÁRIO}

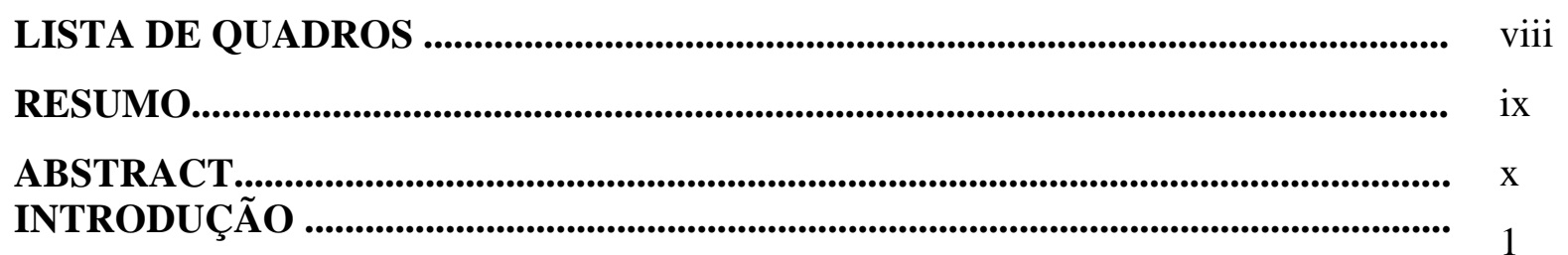

1 ESCRITA E INTERAÇÃO: HISTÓRICO, CONCEPÇÃO E IMPLICAÇÕES NO ÂMBITO ESCOLAR.

1.1. ENSINAR A LER E A ESCREVER: UMA QUESTÃO DE MÉTODOS .... 6

1.1.1. Métodos sintéticos, analíticos e mistos ....................................................... 11

1.2. A APRENDIZAGEM DA ESCRITA EM UMA ABORDAGEM

PSICOGENÉTICA: O PROCESSO DE CONSTRUÇÃO CONCEITUAL.......... 14

1.3. A TRANSPOSIÇÃO DIDÁTICA: A PSICOGÊNESE EM SALA DE AULA

1.4. A CONCEPÇÃO CONSTRUTIVISTA: UM CONJUNTO DE APORTES TEÓRICOS

1.4.1. Vygotsky: a interação social e a apropriação da escrita

1.4.2. Bakhtin: a interlocução na constituição da língua e do sujeito

1.5. LETRAMENTO, ALFABETIZAÇÃO E NOVOS PROCESSOS DE TRANPOSIÇÃO DIDÁTICA

1.6. O MÉTODO FÔNICO: RETOMADA E TENTATIVA PARA SOLUCIONAR OS PROBLEMAS DA ALFABETIZAÇÃO NO BRASIL..........

1.7. CULTURA LETRADA, CULTURA ESCRITA E A ESCRITA COMO UM SISTEMA DE REPRESENTAÇÃO

2 A PESQUISA

2.1. PRESSUPOSTOS TEÓRICO-METODOLÓGICOS 49

2.2. CARACTERIZAÇÃO DA PESQUISA 54 


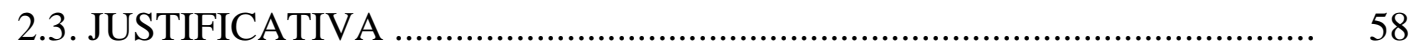

2.4. HIPOTESES E OBJETIVOS .................................................................... 60

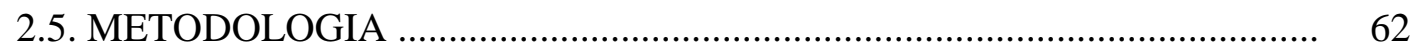

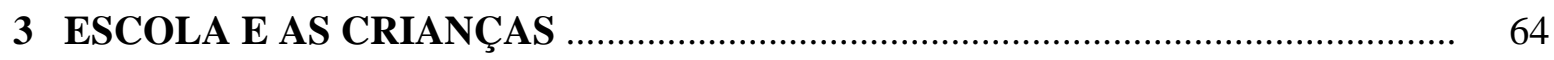

3.1. A ESCOLA E A CONSTRUÇÃO DE CONHECIMENTOS ....................... 64

3.2. BASES PARA O PROCESSO DE COMPREENSÃO DA ESCRITA ......... 66

3.3. CONHECENDO OS ALUNOS.............................................................. 69

3.4. O TRABALHO COM A LÍNGUA NA ESCOLA DA VILA......................... 70

4 O PROCESSO DE PRODUÇÃO TEXTUAL: TENDÊNCIAS NOS ASPECTOS DISCURSIVOS

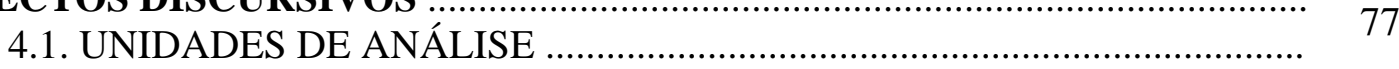

4.2. O PROCESSO REDACIONAL E OS ASPECTOS DISCURSIVOS: A 77 PRODUÇÃO DE LISTAS

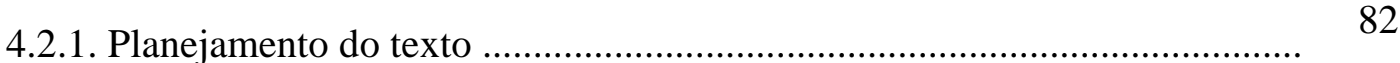

4.2.2. Textualização: refletindo e compondo o texto........................................... 83

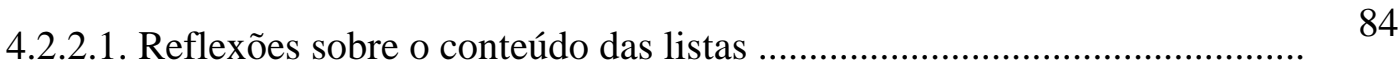

4.2.2.2. Breves considerações sobre o conteúdo das listas

4.2.2.3. Reflexões sobre a estrutura das listas 91

4.2.3. Revisão: avaliando e controlando a produção

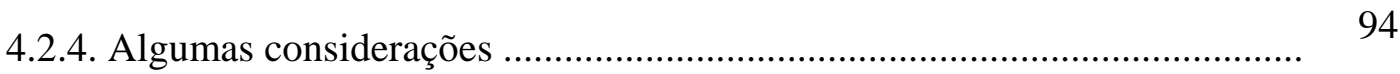

4.3. O PROCESSO REDACIONAL E OS ASPECTOS DISCURSIVOS: A 97 PRODUÇÃO DE PARLENDAS

4.3.1. Planejamento do texto ........................................................................... 97

4.3.2. Textualização: refletindo e compondo o texto ............................................. 98

4.3.2.1. Reflexões sobre a estrutura das parlendas .............................................. 99

4.3.3. Revisão: avaliando e controlando a produção ............................................... 101

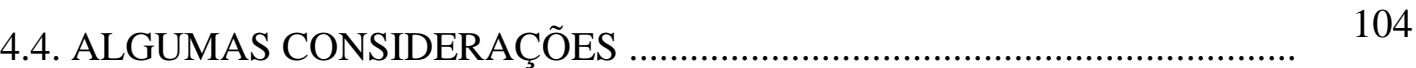


5 O PROCESSO DE PRODUÇÃO TEXTUAL: TENDÊNCIAS NOS ASPECTOS NOTACIONAIS

5.1. A PRODUÇAO ESCRITA E O PROCESSO DE COMPREENSÃO DO SISTEMA ALFABÉTICO ............................................................................. 108

5.1.1. As produções de Beatriz e Luiz ............................................................. 109

5.1.2. As produções de Clara e Pedro H. .......................................................... 112

5.1.3. Interações e momentos conceituais .......................................................... 117

5.2. PLANEJANDO E REVISANDO: ANTECIPAR E RETOMAR ESCRITAS

5.3. PROCEDIMENTOS DE BUSCA DE INFORMAÇÕES: AS PALAVRAS ESTÁVEIS, AS PALAVRAS DE REFERÊNCIA E AS RELAÇÕES SONORAS

5.4. O COMPUTADOR: TAREFAS E REFLEXÕES POSSÍVEIS

5.4.1. O teclado como fonte de informação

5.4.2. O computador ampliando as interações entre a dupla

5.4.3. Além do princípio alfabético: a segmentação e o uso de outras marcas gráficas

5.4.3.1. A segmentação

5.4.3.2. Outras marcas gráficas: os acentos

5.4.4. Números e letras: dois sistemas notacionais na produção de textos 146

5.5. ALGUMAS CONSIDERAÇÕES 147

6 OS PROCESSOS SINGULARES DE APROPRIAÇÃO DA ESCRITA: ESTUDOS DE CASO

6.1. O PERCURSO DE CAMILA 152

6.2. O PERCURSO DE BEATRIZ 161

6.3. SE ALGO SE PODE CONCLUIR. 166 


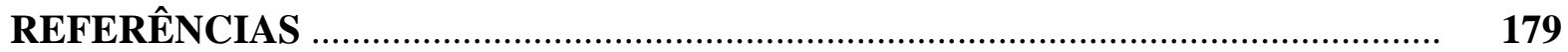

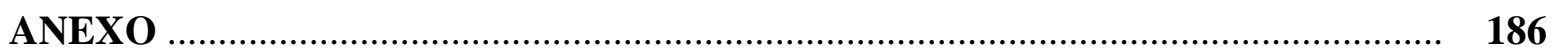




\section{LISTA DE QUADROS}

QUADRO 1 - APRESENTAÇÃO DAS DUPLAS DE CRIANÇAS.................................. 56

QUADRO 2 - INFORMAÇÕES SOBRE OS ALUNOS.................................................. 69

QUADRO 3 - ORGANIZAÇÃO DO CAPÍTULO 4.................................................. 81

QUADRO 4 - ESTRUTURA DAS PARLENDAS......................................................... 102

QUADRO 5 - ORGANIZAÇÃO DO CAPÍTULO 5 ................................................. 108

QUADRO 6 - LISTA DE PALAVRAS PARA CONSULTA......................................... 132

QUADRO 7 - EXEMPLOS DE PALAVRAS ACENTUADAS ..................................... 144 


\section{RESUMO}

LUIZE, Andréa. "O processo de apropriação da escrita na infância: situações interativas na produção textual”. São Paulo: FEUSP, 2007. (Dissertação de Mestrado)

A partir do pressuposto de que a escola é responsável pela inserção cada vez mais ampla dos sujeitos na cultura letrada - o que implica assumir a formação de leitores e escritores competentes como uma das principais metas educativas - e do fato de que as crianças precisam ser consideradas, desde as séries iniciais da educação infantil, como efetivas usuárias da língua escrita, o trabalho tem por objetivo investigar reflexões e ações dos pequenos aprendizes frente a tarefas desafiadoras de produção textual. Tomando a escrita como um sistema de representação configurado em diferentes gêneros textuais, entendendo que interações com esse objeto de conhecimento e com outros aprendizes são necessárias para a ampliação da competência escritora, pretende-se fazer uma análise dos processos de oito duplas de crianças, de 4 a 6 anos. Para tanto, foi proposta a produção de quatro textos (duas parlendas e duas listas) com base em diferentes variáveis: textos conhecidos de memória e textos cujo conteúdo precisava ser criado; textos com estruturas e propósitos comunicativos diversos; textos escritos no computador ou com lápis e papel; textos com a presença de dois sistemas de notação (letras e números). Interessam a esta análise as informações e conhecimentos (de natureza conceitual ou procedimental) intercambiados entre as crianças, que subsidiaram as decisões tomadas na composição dos textos. Os dados coletados permitem a constatação da amplitude das reflexões que as crianças são capazes de realizar, mesmo sem o domínio das convenções do sistema de escrita ou dos gêneros textuais. Além disso, o estudo objetiva situar a interação entre as crianças como fator relevante para as conquistas individuais em seus processos de aprendizagem. Assim, a análise dos dados tem como meta captar os processos cognitivos, mapeando suas tendências mais típicas e, ao mesmo tempo, apreendendo as suas singularidades a fim de enfocar a diversidade inerente à construção do conhecimento e que precisa ser um dos pilares do ensino da escrita. À luz dos postulados de teóricos construtivistas (sobretudo das referências de Piaget, Vygotsky, Coll, Ferreiro e Teberosky) e também de outros teóricos que destacam a importância da interação social na aprendizagem da escrita (entre os quais Bakhtin), a análise de aspectos discursivos e de aspectos notacionais, evidenciados nos processos de elaboração textual, visa contribuir para a revisão das atuais práticas escolares de ensino da escrita, defendendo princípios didáticos pautados na interação, na concepção de escrita como objeto social e histórico de conhecimento e na complexidade da aprendizagem desse objeto.

Unitermos: alfabetização, interação, produção textual, cultura letrada, didática da língua escrita 


\begin{abstract}
LUIZE, Andrea. "The acquisition of the writing process in childhood: interactive situations in text production”. São Paulo: FEUSP, 2007. (Master Essay)

Based on the assumption that the school is responsible for the wider insertion of the individual in the literate culture - which implies assuming the formation of both competent readers and writers as one of the main objectives of education - and on the fact that children must be regarded, from the very early stages of learning, as effective users of the written language, this study aims at investigating young learners' reflections and actions when faced with challenging text production tasks. Assuming writing as a representative system depicted in different types of texts and taking into account that interaction with this object of knowledge and other learners is necessary to amplify the writing competence, one aims at making an analysis of the processes carried out with eight pairs of children, aged 4 to 6 . With this in mind, the production of four texts (two nursery rhymes and two lists) based on different variables was proposed: texts known by heart and texts whose content had to be created; texts with different structures and communicative goals; computer written texts and handwritten texts; and texts which use two different graphic systems (letters and numbers). This case study is mainly concerned with the information and knowledge (of concept or procedure nature) shared by the children, and which subsidised the decisions taken in the actual writing of the texts. The data collected enables the realisation of the amplitude of the reflections which children are able to make, despite their lack of mastery of the writing system conventions or an awareness of the different existing text types. Beside this, the case study aims at placing the interaction among children as a relevant factor for individual achievement in the learning processes, surveying their most typical tendencies as well as distinguishing its singularities so as to focus the inherent diversity of building knowledge, which must be one of the pillars of teaching writing. In the light of the postulates of constructive theorists (Piaget; Vygotsky, Coll, Ferrero and Teberosky) as well as other theorists who emphasise the importance of social interchange in writing (among whom is Bakhtin), the analysis of discursive and notational aspects revealed in the elaboration of the writing process, proposes to help revise the present teaching practices of writing carried out at school, defending principles in which the conception of writing as a social and historical object of knowledge and the complexity of the learning process of this object are present.
\end{abstract}

Terms: literacy, interaction, text production, literate culture, didactic aspects of teaching written language

\title{
INTRODUÇÃO
}

Há que se alfabetizar para ler o que os outros produzem ou produziram, mas também para que a capacidade de “dizer por escrito” esteja 
mais democraticamente distribuída. Alguém que pode colocar no papel suas próprias palavras é alguém que não tem medo de falar em voz alta.

(FERREIRO, 2003, p. 54)

O ensino da língua escrita é uma questão que, há muito tempo, ocupa um lugar de destaque em pesquisas e teorias, não só originando dezenas de metodologias e milhares de materiais didáticos, como também centrando debates políticos e educacionais. A literatura sobre o tema é vasta e diversificada e os debates acerca da capacitação de professores das séries iniciais estão, inúmeras vezes, no cerne das propostas para a transformação ou recuperação do ensino. Publicados pelo MEC no final dos anos 90, os Parâmetros e Referenciais Curriculares fundamentam-se em princípios construtivistas e enfatizam o papel da escola na formação de leitores e escritores. Porém, a despeito das diretrizes nacionais, alfabetizar continua a ser uma das tarefas mais problemáticas das escolas brasileiras. Contrariando as expectativas, muitas crianças seguem a trajetória da vida escolar sem dominar a escrita alfabética, de tal forma que, mesmo depois de quatro anos ou mais, são ainda incapazes de ler e escrever convencionalmente palavras, frases ou pequenos textos. Em outros casos, adolescentes e jovens concluem sua escolaridade básica dominando as tarefas de "codificar" e "decodificar" - assim consideradas oficialmente como leitoras e escritoras -, mas sem estar efetivamente aptas a interpretar textos e se comunicar por escrito.

O que se observa é uma significativa distância entre a escrita que existe socialmente e aquela que a escola deseja ensinar. Na prática pedagógica, há ainda uma distância, por vezes intransponível, entre como se ensina e como as crianças aprendem. Nem o objeto "escrita" foi ainda compreendido pela prática docente tampouco os processos de aprendizagem são conhecidos e levados em conta nas propostas pedagógicas. A preocupação de "como ensinar", “por onde começar” ou "por meio de quais atividades ou métodos” parecem tão enraizadas que tendem a se fechar em si mesmas, não permitindo que se veja os percursos trilhados pelos aprendizes: como aprendem e que escrita é essa, foco de suas preocupações e reflexões.

No âmbito das discussões em que se insere a temática das práticas escolares de alfabetização, a pesquisa didática parece urgente. Planejar situações de escrita que tomem a língua em sua pluralidade, permitir que as crianças interajam com os textos escritos (como 
produtoras, interpretes, revisoras etc.), com situações reais de comunicação e com outros sujeitos envolvidos nesse processo, podendo promover intercâmbios favoráveis à aprendizagem, são desafios impostos aos professores. Nesse sentido, a pesquisa didática pode contribuir para que eles compreendam melhor esses desafios, além de construir práticas coerentes com as demandas de uso social da escrita e com as demandas da própria aprendizagem. Pesquisas dessa natureza não se prestam a dar receitas ou fórmulas mágicas para o fazer diário em sala de aula, mas para apoiar as decisões que o professor precisa tomar como mediador das interações que podem se estabelecer entre os aprendizes e a escrita e entre os próprios aprendizes.

A pesquisa que ora se apresenta nesta dissertação objetiva colaborar com a prática docente a partir da análise de processos de produção textual vividos por duplas de crianças pequenas, entre 4 e 6 anos aproximadamente. Observando seus processos e os produtos da sua elaboração, é possível questionar: o que pensam as crianças quando precisam escrever e se comunicar por meio de diferentes textos? Como solucionam problemas que a escrita lhes traz sem que dominem as convenções? Que tipo de intercâmbio podem estabelecer quando dividem tarefas com outro aprendiz? Como lidam com a escrita concretizada com uso de recursos diferentes: com o lápis e o papel ou com o computador? Essas são algumas das questões que norteiam a análise a ser feita e que se instauram como importantes eixos da própria intervenção didática.

As situações de escrita propostas às crianças, sujeitos da pesquisa, são exemplares típicos do que, nos parâmetros de ensino construtivista, deveria fazer parte do cotidiano escolar, entendendo que a escrita existente fora dos muros da escola é a mesma que deve estar dentro da sala de aula; entendendo que as crianças são seres ativos e pensantes, capazes de observar, refletir e formular hipóteses sobre o universo letrado que as rodeia e, finalmente, entendendo que a tarefa docente consiste em favorecer aprendizagens pela problematização do objeto de conhecimento a escrita -, de modo a possibilitar que os alunos atuem como verdadeiros usuários da língua, desde os primeiros anos da Educação Infantil.

No estudo realizado, a concepção construtivista de aprendizagem delimita tanto as referências teóricas como as opções metodológicas e a própria análise baseada nos processos de produção dos textos solicitados às duplas de crianças. Dentre os teóricos e investigadores de referência, Emilia Ferreiro ocupará um espaço significativo na fundamentação da proposta e da análise, pela vasta e rica contribuição que tem dado em seus diferentes estudos, sempre pautados 
nos postulados piagetianos, para a compreensão da aprendizagem da escrita. Seja pela concepção do próprio objeto que se quer ensinar ou ainda pelos debates que tem promovido a respeito das dimensões social e política que cercam o tema da alfabetização, pensar sobre a prática didática favorecendo a construção de conhecimentos, sobretudo sobre a escrita, só tem sido, de fato, possível em virtude da atuação dessa renomada pesquisadora.

Os estudos de Vygotsky serão tomados como outras importantes referências, em especial pela importância atribuída à interação social e sua influência na aprendizagem e pelas pesquisas que acompanhou no campo da escrita.

Na concepção de linguagem que fundamentou o trabalho, as idéias de Bakhtin foram também importantes para apoiar a relevância dos processos de interlocução na aprendizagem da escrita.

Conceitualizar "escrita" e "interação" se constitui como base para o entendimento da prática docente, para a compreensão tanto dos processos apresentados pelas crianças nas propostas desta pesquisa quanto para sua respectiva análise. Tais conceitos serão tematizados, enriquecidos e integrados pela idéia de inserção, cada vez mais ampla, dos aprendizes em sua “cultura letrada”, tomada como meta da escola no ensino da língua.

O capítulo 1 destina-se, justamente, à apresentação teórica de três importantes conceitos (escrita, interação e cultura letrada), também revisando brevemente parte do percurso histórico brasileiro no que se refere ao tema da alfabetização e dos usuais métodos utilizados com tal propósito. Situar a concepção construtivista e discorrer sobre processos de transposição didática de pesquisas básicas para a sala de aula também são temas que compõem este capítulo inicial.

No capítulo 2, discute-se os procedimentos metodológicos que estruturam a pesquisa. Pressupostos fundamentais são salientados, entre os quais as noções de erro e conflito cognitivo, porque justificam a opção de analisar os processos interlocutivos de produção textual e não só seu produto.

No capítulo 3, faz-se a apresentação dos pequenos escritores que participaram com imensa naturalidade, disponibilidade e desenvoltura das situações de pesquisa. Antes, porém, para que se possa compreender parte da análise, será situada a escola em que estudam essas crianças. Por se tratar de uma instituição renomada, um centro de referência no ensino pautado nos princípios construtivistas, torna-se importante conhecer, em linhas gerais, o trabalho feito 
pelos professores em relação à escrita e as concepções que fundamentam as decisões tomadas no âmbito da sala de aula.

No capítulo 4, inicia-se a análise dos processos de produção textual com ênfase nos aspectos discursivos que centraram reflexões e decisões das crianças. Tal análise será feita à luz das principais tendências reveladas pelas parcerias na composição dos textos. As diferenças na elaboração de dois gêneros textuais e propósitos comunicativos específicos são os aspectos destacados nesse capítulo.

No capítulo 5, faz-se a análise dos aspectos notacionais que marcaram as reflexões e discussões das parcerias. Novamente, a meta é salientar regularidades observadas, sobretudo considerando a apropriação do princípio alfabético. Algumas singularidades dos processos de aprendizagem são também discutidas e tidas como favoráveis para a compreensão das interações entre as crianças e entre essas e a própria escrita. O capítulo contempla ainda questões atreladas ao uso do computador, recurso utilizado para duas das quatro produções propostas.

No capítulo 6, a importância de observação e acompanhamento dos processos individuais ganha evidência. Em dois estudos de caso são analisados os percursos de crianças, que, estabelecendo uma interação diferente e peculiar com suas respectivas duplas, explicitam, ao longo das situações de pesquisa, avanços conceituais e procedimentais bastante significativos.

Por fim, as conclusões possíveis a partir dos dados obtidos e da análise feita, bem como suas implicações diretas para a prática didática em uma ótica construtivista, ótica que embasa, justifica e orienta o presente trabalho. 


\title{
1 ESCRITA E INTERAÇÃO: HISTÓRICO, CONCEPÇÕES E IMPLICAÇÕES NO ÂMBITO ESCOLAR
}

\author{
[...] a escrita é importante na escola \\ pelo fato de que é importante \\ fora da escola, não o contrário.
}

(FERREIRO, 2001a, p. 33)

Ensinar a ler e escrever representa, hoje em dia, uma das mais prioritárias metas da escola e igualmente um de seus maiores desafios. Formar um sujeito capaz de lidar de maneira competente com as situações sociais que envolvem a escrita e a leitura não é, porém, um objetivo inovador da instituição escolar do século XXI. Ao contrário, desde sempre, pode-se dizer que essa seja, de fato, uma das suas preocupações fundamentais. Como destaca Mortatti (2000, p. 21),

[...] a análise das fontes documentais sobre o ensino da leitura e escrita no Brasil permite observar que anúncios e necessidades desse tipo não são exclusivos deste presente histórico, podendo ser localizados desde o final do século XIX, pelo menos.

Tanto naquela como em nossa época, a alfabetização é apresentada como um dos instrumentos privilegiados de aquisição de saber e, portanto, de esclarecimento das 'massas'. Torna-se, assim, necessário implementar o processo de escolarização das práticas culturais da leitura e escrita, entendidas, do ponto de vista de um certo projeto neoliberal, como fundamentos de uma nova ordem política, econômica e social.

Ao longo dos anos, instauram-se discussões sobre o tema da alfabetização inicial que assumem focos e perspectivas diferenciadas, entre outras razões, pelos resultados e evidências trazidos por pesquisas de caráter acadêmico. Qual a melhor maneira de ensinar? O que é realmente a escrita como objeto de ensino? Como as crianças aprendem? Essas são algumas das questões cruciais que norteiam os debates sobre a tarefa de alfabetizar e que merecem um destaque no capítulo inicial da presente investigação.

Não se tem como pretensão abordar ampla e profundamente as discussões sobre alfabetização evidenciadas nas últimas décadas, tampouco chegar a respostas precisas para as questões citadas acima. O propósito deste capítulo é apresentar, em linhas gerais, a problemática atual do ensino da leitura e da escrita, não só para contextualizar os referenciais construtivistas como também para situar a presente pesquisa, justificando sua relevância. Nesse sentido, é 
preciso iniciar esta apresentação com o tema dos métodos de alfabetização que tanto centrou os debates educacionais e que, recentemente, vem ressurgindo em centros de estudos psicológicos, ganhando corpo na mídia (principalmente em jornais de grande circulação, programas de TV em redes abertas e fechadas e revistas especializadas) e mais evidência no interior da escola.

\subsection{ENSINAR A LER E A ESCREVER: UMA QUESTÃO DE MÉTODOS}

Já há muitas décadas, as discussões sobre a alfabetização no Brasil têm seu foco no método a ser utilizado: a busca por alternativas metodológicas impõe-se como um desafio aos educadores no enfrentamento ao analfabetismo. É por essa razão que se faz necessário compreender a questão dos métodos do ponto de vista histórico; é preciso entender "que as mudanças de rumo no pensamento sobre a alfabetização alteram os modos de alfabetizar”. (ZACHARIAS, 2005, p. 92)

Inseridos em um movimento de continuidade e descontinuidade, os debates acerca do melhor método parecem atuar sempre em um processo de crítica ao tradicional e apresentação de algo inovador. Segundo Mortatti (2000, p. 24), nesse processo “diferentes sentidos vão-se configurando para os pares de termos 'moderno'/'novo' e 'antigo'/'tradicional’”.

Embora não se possa tecer um quadro histórico absolutamente delimitado por datas, alguns momentos cruciais de tensões são identificados pela referida pesquisadora e serão aqui brevemente apresentados, com o intuito de situar a temática dos métodos relacionados à alfabetização.

Um primeiro momento de conflito entre o tradicional e o novo no campo da alfabetização iniciou-se no final do século XIX. Contestações ao mais usual método de alfabetização no Brasil, a soletração - pautado no ensino “do nome das letras que devem ser soletradas pelo aprendiz, ou seja, consiste em dizer todas as letras das sílabas para pronunciá-las e assim seguir até ler toda a palavra” (ZACHARIAS, 2005, p. 92) -, eram feitas especialmente por Antonio da Silva Jardim, um professor partidário da corrente positivista. Preocupado com a necessidade de avanços culturais, políticos e econômicos e tecendo críticas ao Império, o estudioso defendia a expansão do ensino da leitura e da escrita também por meio da elaboração e distribuição de livros para as escolas e tomava como base o método da palavração. A organização de um material didático - uma cartilha e livros de leitura - concretizou o projeto inovador 
defendido por Silva Jardim, o qual conferia maior importância à leitura do que à escrita. A leitura era entendida como um "processo de apreensão da idéia representada pela palavra, a partir da síntese - soma dos valores das letras - e que demanda ênfase na educação do ouvido”. Já a escrita funcionava como “auxiliar no aprendizado da leitura' e era concebida como uma “técnica caligráfica”. (MORTATTI, 2000, p. 71)

Embora a "Cartilha Maternal", de autoria do poeta português João de Deus, base de divulgação do método da palavração, não tenha tido uma longa permanência nas escolas brasileiras e tampouco a proposta de Silva Jardim tenha recebido notoriedade oficial, não se pode negar o caráter precursor desse primeiro movimento de crítica à forma mais rotineira de alfabetização no Brasil: o ensino pela soletração e silabação, centradas nas letras e sílabas, respectivamente. Mortatti também salienta a influência desse movimento na constituição do ensino da leitura como um objeto de estudos e pesquisas de natureza interdisciplinar, visto que Silvia Jardim defendia seus pressupostos com base em princípios pedagógicos, psicológicos, filosóficos e lingüísticos.

O segundo momento marcante de críticas, que começou na última década do século XIX, aproximadamente, e ganhou evidência no início do século seguinte, sob influência européia e norte-americana, trouxe as novas idéias do método analítico para a sala de aula. Dentre os defensores e divulgadores desse método estavam alguns alunos normalistas de São Paulo, que, depois da Proclamação da República, passaram a exigir a atuação de professores em cargos públicos, atrelados à política educacional, funções antes atribuídas a bacharéis de Direito.

O método analítico tinha como base o ensino da leitura por meio da análise inicial de unidades mais amplas do que a sílaba, partindo, portanto, de sentenças. O cerne dessa proposta estava em ensinar frases curtas das quais eram extraídas palavras, analisadas sílabas e, finalmente, letras. Tal método teve ampla divulgação no Brasil com a produção de cartilhas por professores, adaptadas às demandas da língua portuguesa e adotadas oficialmente, a fim de “uniformizar o ensino da leitura” (aspecto também responsável por consolidar “o mercado editorial de livros didático” e profissionalizar seus escritores). (MORTATTI, 2000, p. 87 e 85)

A despeito da notoriedade do método analítico, o período trouxe também tentativas de manutenção do que, nesse momento, passou a ser considerado "tradicional” e “antigo". Artigos publicados na "Revista de Ensino", criada aproximadamente na mesma época, contêm críticas acirradas à suposta falta de lógica do método analítico e às vertentes de sua aplicação nas salas de 
aula. A defesa da palavração centrava-se na necessidade do ensino da leitura a partir de suas partes menores: conhecer os aspectos fônicos do nosso sistema era efetivamente o que se julgava essencial para a compreensão leitora e, portanto, de onde deveria partir a alfabetização.

Várias cartilhas foram elaboradas a partir desse período, tanto adotando como referência a palavração quanto as novas propostas analíticas (e nesse caso, tendo como pontos de partida sentenças ou pequenas histórias). Importante ressaltar a ampliação dos grupos defensores de diferentes abordagens desse método, gerando conflitos e discordâncias internas e marcando a produção de diferentes livros didáticos. Além disso, cada subgrupo era considerado mais ou menos moderno a depender da vertente que defendia. O método analítico ganhou vertentes diversas, sobretudo considerando o ponto de partida da alfabetização: "palavras concretas e significativas” para as crianças; palavras associadas a desenhos (método “ideovisual”); sentenças e contos (a partir de "uma seqüência de contos, com sentidos complementares”) (ZACHARIAS, 2005).

Tais disputas perderam parte de sua relevância com a instauração da Reforma Sampaio Dória (1920), que delimitou a não obrigatoriedade do uso do método analítico, ainda que reconhecido como favorável para a aprendizagem da leitura.

Também é necessário apontar que algumas cartilhas analíticas elaboradas nessas datas (final do século XIX e início de 1900) evidenciavam preocupações atreladas à necessidade de um preparo prévio a alfabetização, à necessidade de um certo “despertar” para a leitura (MORTATTI, 2000).

A busca pela modernidade constante e por avanços no campo da instrução pública tornou esse segundo momento rico em debates e publicações sobre o ensino e, definitivamente, situou a questão da leitura como um objeto de estudos científicos.

É na década de 20 que surgem as primeiras críticas ao uso do método analítico e, mais especificamente, aos princípios e propósitos que regiam a instrução pública até aquele momento. Lourenço Filho e Anísio Teixeira, com base nas idéias da “escola nova”, defendiam uma extensa modernização da escola para adequação à nova sociedade, idealizada por esse movimento.

O movimento da "escola nova” teve seus fundamentos na psicologia, conforme afirma Coll (In LEITE, 1987, p. 166):

A psicologia funcional de W. James (1842-1920), J. Dewey (1859-1952), E. Claparède e outros autores servirá como guia e suporte para os movimentos de 
renovação pedagógica que, com a denominação de educação progressiva e de educação ativa ou escola nova, se desenvolveram nos Estados Unidos e na Europa, respectivamente, durante as primeiras décadas de nosso século.

No Brasil, o ensino da leitura e da escrita passou também a ser enfatizado sob o viés da psicologia aplicada e a concepção de alfabetização ganhou evidência pela amplitude a ela conferida, visto englobar o caráter "funcional e instrumental” da língua; leitura e escrita foram tomadas como capazes de favorecer avanços no desenvolvimento intelectual. Justamente pela importância atribuída ao ler e escrever, a busca pela “democratização da cultura” e a preocupação com a alfabetização popular marcaram a “escolada renovada” (MORTATTI, 2000).

Nas instâncias acadêmicas e políticas, Lourenço Filho conquistava maior notoriedade nacional e internacional, embora no interior das escolas a diversidade de métodos ainda se fizesse vigente; o uso das cartilhas analíticas era uma prioridade. Mesmo presente nas escolas, a defesa ao método analítico vai se diluindo com os ideais da "escola renovada" preocupada principalmente com a alfabetização em massa. Nasceram, com esse propósito, novas soluções de caráter técnico a fim de tornar mais eficiente e rápido o ensino inicial da leitura e da escrita, sem que se deixasse de considerar a necessidade de maturidade para tal aprendizagem. $\mathrm{O}$ método misto - incorporando os princípios de análise e de síntese - ganhou defensores e passou a ocupar um espaço significativo nos meios escolares.

A questão da excessiva repetência nas séries iniciais, já identificada nesse período, foi considerada por Lourenço Filho, com base em estudos da psicologia experimental, um fator problemático a ser sanado. Em seus textos e discursos, o autor privilegiou a maturidade e a prontidão para a alfabetização, propondo formas de medi-las. Idéia relevante desse momento, e que até hoje guarda seus resquícios, foi a atribuição do fracasso escolar ao aluno em virtude do seu nível de maturidade. A criação dos “Testes ABC” para diagnosticar a prontidão para a alfabetização deu ainda mais importância ao autor. Aplicados por mais de 50 anos, esses testes tinham por finalidade mensurar a maturidade do aluno para o início do processo de alfabetização. Para avaliação do perfil do aluno e também para a composição de grupos-classe, os testes eram tomados como simples e eficientes e tinham como meta verificar determinados aspectos, entre os quais:

coordenação visual-motora, resistência à inversão na cópia da figura, memorização visual, coordenação auditivo-motora, capacidade de prolação, 
resistência à ecolalia, memorização auditiva, índice de fatigabilidade, índice de atenção dirigida, vocabulário e compreensão geral (MORTATTI, 2000, p. 151).

Do ponto de vista prático, além da aplicação dos testes para avaliação da maturidade do aluno, também entraram nas salas de aula novas cartilhas, duas das quais criadas pelo próprio Lourenço Filho. Embora, segundo seu autor, pudessem ser aplicadas tanto no uso do método sintético como em métodos analíticos, a opção pelo método misto ganhou expressão nesses materiais. A cartilha “Upa, cavalinho!” incluía lições iniciais voltadas para as sentenças e palavras e outras cuja finalidade era a silabação. Ao final do manual, as sílabas apresentadas eram reorganizadas de modo a compor novas palavras.

É também nesse período que o mercado editorial passou a investir intensamente na produção de novas cartilhas. Duas delas exerceram ampla e forte influência na atuação didática: a “Cartilha Sodré” (de autoria de Benedicta Sodré) e a "Caminho Suave” (de Branca Alves de Lima). Destinadas diretamente ao ensino inicial da leitura e escrita, as cartilhas traziam um conjunto de lições, com apresentações do tema e exercícios de aplicação e fixação. Ambas as cartilhas pautavam-se em métodos já conhecidos, mas adaptados de acordo com as experiências de suas autoras. A “Cartilha Sodré” baseava-se na silabação, enquanto a "Caminho Suave”, no método analítico-sintético.

Em suas inúmeras edições, a cartilha "Caminho Suave” (cuja primeira publicação data de 1948) evidencia um trabalho com imagens e com a leitura de conjuntos de frases curtas, chamando a atenção para uma determinada família silábica ou para a letra a ser fixada naquela unidade. Em edições da década de 70, passou a incorporar um amplo manual de instruções para o professor, com o intuito de favorecer sua aplicação, e ainda defendia o uso dos testes para verificação da prontidão necessária à aprendizagem. A inserção dessa cartilha nas escolas foi realmente intensa durante mais de 40 anos e o material chegou a ser publicado até o início dos anos 2000. Gerações de alunos e professores se remetem a esse material como base, respectivamente, para a aprendizagem e o ensino da leitura e da escrita.

Segundo Mortatti (2000), ao contrário dos dois primeiros movimentos, não se tem como precisar os marcos iniciais e finais desse terceiro grande movimento caracterizado pela diluição das acirradas disputas anteriores, pela criação de indicadores de maturidade, pela difusão do método misto e pela intensa defesa da alfabetização popular. A tradição das cartilhas e a 
expansão do mercado editorial voltado à formação dos professores são outras marcas significativas desse período.

Apesar das diversas críticas que se possa tecer a esse terceiro momento, não se pode negar a importância da defesa ao aluno como um indivíduo em particular, focando o olhar da educação para a heterogeneidade. Do mesmo modo, tem-se, aqui, a expansão da leitura e da escrita como tema de estudo também por parte dos próprios professores, que passam a ter à disposição inúmeros livros de pesquisas, teorizações e relatos de experiências. A formação dos professores ganha assim mais evidência.

Mesmo sem ter como cerne a questão metodológica, o movimento marcado pelas idéias da "escola nova” não deixou, assim como os anteriores, de defender o uso de métodos para a alfabetização. Esse critério mantém-se ao longo das décadas e, nos anos 70, as escolas brasileiras podiam ser classificadas de acordo com a metodologia utilizada para ensinar as crianças a ler e escrever. A aplicação dos métodos sintéticos e analíticos era vigente, embora a maior parte das escolas utilizasse o método misto.

Para fins da presente pesquisa, vale discorrer um pouco mais sobre a questão dos métodos com o objetivo de identificar semelhanças e desvantagens dos mesmos e contextualizar as críticas feitas pela pesquisa psicogenética, detalhadas a partir do próximo item.

\subsubsection{Métodos sintéticos, métodos analíticos e método misto}

Antes de discutir os aspectos críticos dos métodos de alfabetização, importa caracterizálos e diferenciá-los. Para tanto, serão considerados três grandes agrupamentos: métodos sintéticos, métodos analíticos e método misto.

Os métodos sintéticos tomam como ponto de partida as menores unidades da língua, menores do que a palavra: as letras, as sílabas ou os fonemas. As propostas que integram esse conjunto também têm em comum a tentativa de ensinar a escrita pelas correspondências entre “oral e escrito, entre o som e a grafia”, sempre das partes para o todo. A silabação, a soletração e o método fônico são exemplos desse conjunto. (FERREIRO; TEBEROSKY, 1985, p. 19)

Criado a partir de forte influência da lingüística, o método fônico propõe que se inicie a alfabetização com base não nas letras, mas nos sons, ao contrário do que era feito no método de 
soletração. A proposta é ensinar, por meio da análise dos sons isolados, o reconhecimento dos fonemas da nossa língua.

Dentre os princípios desse método está a necessidade do sujeito “aperfeiçoar” sua pronúncia para não prejudicar a relação entre fonema e grafema (som e letra). Seguindo os preceitos da psicologia associacionista, estabelece-se como primordial que cada par de fonemagrafema seja apresentado separadamente e não se ensine um novo até que esse tenha sido realmente apropriado pela criança.

Os métodos analíticos, ao contrário dos de caráter sintético, têm por pressuposto o ensino de unidades maiores do que as sílabas (palavras, frases ou historietas), a fim de se partir do todo para a análise das partes, possibilitando à criança trabalhar com unidades mais significativas.

Os métodos de caráter misto (ou analítico-sintético), por sua vez, representam uma junção de propostas de análise e síntese, mesclando situações em que se foca a atenção do aluno na leitura de pequenos textos, frases e palavras e outras em que a silabação e o conhecimento de letras e/ou sons são instigados.

Mesmo com diferenças marcantes em seus pressupostos e na forma de ensinar, os métodos sintéticos, analíticos e misto têm em comum a concepção de que a alfabetização é uma aprendizagem mecânica, dada pelo domínio progressivo da decifração para a leitura e pela técnica de combinar as partes sonoras e gráficas. Toma-se a escrita e a leitura como meras técnicas. Tanto é desse modo que, apenas depois do domínio do código alfabético, as crianças serão convidadas a utilizá-lo em situações de produção e leitura de pequenos textos, com o propósito de automatizar a escrita e de obter maior fluência leitora.

Como destaca Zacharias (2005, p. 94): “a abordagem da alfabetização centrada nos métodos é grandemente redutiva, principalmente em relação a sua conceituação do objeto de conhecimento e a sua visão daquele que aprende”.

Os métodos exibem um conjunto fechado de passos a ser seguido igualmente por todos os alunos, sem levar em conta experiências, interesses e demandas de caráter individual, cruciais para o processo de aprendizagem. Embora nos anos 70 já se tivesse um olhar para a heterogeneidade, as preocupações ainda estavam atreladas às diferenças à prontidão para aprender e à necessidade de um preparo prévio dos alunos para a alfabetização, especialmente 
pelas atividades e exercícios focados na percepção, na coordenação viso-motora, na lateralidade etc. Como destacam Poppovic e Moraes (1966, p. 5),

\begin{abstract}
prontidão para a alfabetização significa ter um mínimo suficiente, sob determinados aspectos, para iniciar o processo da função simbólica que é a leitura e sua transposição gráfica, que é a escrita.

De maneira geral, os aspectos que fazem parte deste processo podem ser classificados em intelectuais, afetivos, sociais e funções específicas. [...]

Os problemas que podem advir de uma deficiência nestes campos devem ser sempre levados em consideração, devido á influência direta que podem ter sobre a alfabetização e sua preparação.
\end{abstract}

Em paralelo à idéia de preparação para o processo de alfabetização, estava a preocupação com as causas efetivas do analfabetismo, o que deu origem a várias teorias explicativas, sendo uma delas a da carência cultural defendida por Poppovic e outros pesquisadores, que julgava a escola inadequada para receber alunos oriundos de classes baixas por estar organizada de acordo com “padrões culturais” da classe média (POPPOVIC, 1972).

Sem deixar de considerar a relevância desses estudos, as preocupações no interior das escolas ainda recaíam sobre o método de ensino. O problema da alfabetização nessa época parecia se resolver sanando a carência das crianças (alimentar, afetiva, cultural, lingüística etc.), favorecendo a prontidão para a aprendizagem e elegendo-se o melhor método. $\mathrm{O}$ foco dessas discussões centrava-se no “como” ensinar. O processo de aprendizagem não era investigado por ser concebido como pura decorrência do ensino. Nessa perspectiva, as crianças eram tidas como seres passivos que "receberiam” o que lhes fosse transmitido desde que estivessem devidamente “preparadas”. Tal crença era tão marcante que as reprovações tendiam mesmo a ser legitimadas pelas variáveis inerentes ao aluno: problemas familiares, problemas atitudinais, carência cultural, afetiva, lingüística e até mesmo alimentar, conforme apontavam estudos sobre o tema (Cf. PATTO, 1999).

É justamente nesse contexto que a pesquisa psicogenética centrada na Língua é publicada no Brasil e passa a ser divulgada também em documentos oficiais, sobretudo no início dos anos 80. Marcada pelo referencial piagetiano e realizada por pesquisadoras argentinas, lideradas por Emilia Ferreiro, essa investigação tomou um rumo diferenciado: suas precursoras julgaram necessário pesquisar como as crianças aprendiam a escrever e o que compreendiam sobre a escrita e a leitura, antes mesmo de se tornar delas usuárias convencionais. Essa ampla 
investigação teve repercussões extremamente significativas no campo do ensino da Língua e da própria educação, por destacar que a aprendizagem da escrita não é apenas uma conquista procedimental, mas um processo que envolve um complexo jogo cognitivo de conceitualização e apropriação das práticas sociais de uso. Analisar a aprendizagem da escrita do ponto de vista conceitual significa, portanto, entendê-la como "um verdadeiro processo de elaboração $e$ construção pessoal”, idéia que gera um forte abalo nas crenças vigentes. (ZABALA, 1998, p. 43, grifos do autor)

Tal pesquisa, como se sabe, teve um impacto decisivo na compreensão do tema da alfabetização, dando início a um importante processo de revisão das posturas teóricas e práticas relativas a essa questão.

\subsection{A APRENDIZAGEM DA ESCRITA EM UMA ABORDAGEM PSICOGENÉTICA: O PROCESSO DE CONSTRUÇÃO CONCEITUAL}

Diferentes conceitos devem ser compreendidos pelas crianças para que aprendam a escrever alfabeticamente. A pesquisa psicogenética centrada na língua teve o mérito não só de trazê-los à luz, como também de explicitá-los enquanto processo de construção de conhecimentos. Emilia Ferreiro e Ana Teberosky, em conjunto com outros pesquisadores, permitiram que os educadores se colocassem do ponto do vista de quem aprende e, assim, analisassem a leitura e a escrita em suas formulações mais elementares, produzidas por crianças que não dominam convencionalmente tais procedimentos. Realizando uma aprofundada investigação, esses estudiosos conseguiram identificar uma série de conceitos que elas gradativamente constroem na tentativa de compreender os princípios geradores da escrita (FERREIRO; TEBEROSKY, 1999) ${ }^{1}$.

Colocando-se em oposição aos princípios que sustentavam os debates e a busca por “bons métodos de ensino”, os estudos psicogenéticos transferem o foco de preocupação do como ensinar para o como se aprende.

\footnotetext{
${ }^{1}$ Como a proposta de pesquisa foi dirigida a crianças que ainda não dominam o princípio alfabético do sistema de escrita, as considerações e análises desenvolvidas no presente trabalho deixam de lado as especificidades de outras faixas etárias e de outros momentos do processo de aquisição da língua escrita.
} 
Entre as propostas metodológicas e as concepções infantis há uma distância que pode medir-se em termos do que a escola ensina e a criança aprende. $\mathrm{O}$ que a escola pretende ensinar nem sempre coincide com o que a criança consegue aprender. Nas tentativas de desvendar os mistérios do código alfabético, o docente procede passo a passo, do 'simples ao complexo', segundo uma definição própria que sempre é imposta por ele. O que é próprio dessa proposição é atribuir simplicidade ao sistema alfabético. Parte-se do suposto de que todas as crianças estão preparadas para aprender o código, com a condição de que o professor possa ajudá-las no processo. A ajuda consiste, basicamente, em transmitir-lhes o equivalente sonoro das letras e exercitá-las na realização gráfica da cópia. O que a criança aprende - nossos dados assim o demonstram é função do modo em que vai se apropriando do objeto, através de uma lenta construção de critérios que lhe permitam compreendê-lo (FERREIRO; TEBEROSKY, 1999, p. 290-291).

A busca por um método, entendido como um conjunto de passos a ser seguido para ensinar a ler e escrever, está calcada na idéia da escrita como um objeto fechado, somente uma técnica codificada e não um sistema de representação, ou seja, uma aprendizagem que requer necessariamente um processo de reflexão e gradativa apropriação. Desconsidera-se que a base desse conhecimento

[...] é de natureza conceitual. Isto é, a mão que escreve e o olho que lê estão sob o comando de um cérebro que pensa sobre a escrita que existe em seu meio social e com a qual toma contato através de sua própria participação em atos que envolvem o ler ou o escrever, em práticas sociais mediadas pela escrita (WEISZ In FERREIRO; TEBEROSKY, 1999, p. ix).

Há também em foco a forma como as respostas infantis são vistas pelos defensores dos métodos para a alfabetização. Quando se toma a escrita apenas como um sistema codificado e fechado, as hipóteses que as crianças constroem para conceitualizar o objeto, e que fogem dos padrões convencionais desse sistema, são vistas como falta de conhecimento, razão pela qual devem ser corrigidas.

As contribuições da pesquisa psicogenética encerraram essa discussão sobre aos métodos. Quando se reflete sobre como a criança aprende e sobre as idéias que desenvolve nesse percurso, fica claro que diferentes processos cognitivos convivem em uma mesma sala de aula. Método algum é capaz de abarcar essa diversidade pela própria natureza que possui: iguais etapas a ser percorridas por todas as crianças, os mesmos aspectos sobre os quais concentrar sua atenção, a proposta de trabalhar a partir de critérios adultocêntricos, seguindo uma suposta lógica 
do mais simples para o mais complexo, impondo uma ordem externa e artificial ao aluno para a aprendizagem.

A amplitude, diversidade e complexidade do processo de construção da escrita podem ser percebidas na singularidade como os sujeitos lidam com o ler e escrever e como evoluem a partir de grandes movimentos cognitivos, verdadeiros saltos qualitativos, ao se aproximarem desse objeto conceitual. De modo geral, é possível distinguir dois momentos aparentemente contraditórios no processo de alfabetização inicial (COLELLO, 1990). Em primeiro lugar, importa compreender “o que” de fato a escrita representa. A descoberta da representação gráfica da fala coloca em jogo a necessidade de compreender o vínculo entre dois sistemas de comunicação: a fala e a escrita. Contudo, as relações entre ambos são complexas e estão longe de ser diretas. Cada sistema tem seu próprio funcionamento, seu papel e suas regras, o que exige, em um segundo momento, a compreensão dessas especificidades. Ao tentar entender “como” a escrita representa, é preciso desvincular fala e escrita para poder situá-las como sistemas autônomos de comunicação. Os processos cognitivos que marcam os dois momentos dessa trajetória, com seus focos de conflitos e contradições, explicitados desde as primeiras publicações da década de 80, continuam a ser minuciosamente estudados por inúmeros investigadores, entre os quais podemos citar as próprias Emilia Ferreiro e Ana Teberosky, além de Liliana Tolschinsky, Sofía Vernon, Telma Weisz, Lúcia Browne Rego, Beatriz Cardoso, Bernadete Abaurre, Terezinha Nunes entre outros.

A descoberta da escrita alfabética é o ponto culminante no início dessa trajetória, quando o aprendiz já é capaz de compreender os princípios geradores de nossa escrita e de realizar uma análise fonética. É certo que ainda há muito em jogo, pois ter entendido os princípios geradores do sistema não significa conhecer todas as suas regras de ordem ortográfica ou gramatical, nem ter o domínio sobre os modos de produção e de interpretação. Se o aprendiz tem conquistas a fazer em relação ao sistema notacional, mais conquistas precisa alcançar para se tornar experiente e competente nas tarefas de ler e de escrever. Isso quer dizer que não basta conceitualizar o sistema alfabético e conquistar certa autonomia nos atos de ler e escrever para atuar como usuário competente da língua escrita. Tendo em vista que o sistema é um meio de representação, uma via de interlocução que precisa igualmente ser apropriada nas suas múltiplas possibilidades comunicativas, é preciso que as crianças aprimorem seus conhecimentos sobre as diferentes situações em que a escrita é utilizada socialmente, que conheçam os gêneros textuais, suas 
características e funções, que experimentem procedimentos comuns a qualquer escritor (tais como planejar, textualizar e revisar) e ainda que lidem com os mais variados destinatários para seus textos, tendo problemas de naturezas diversas para resolver.

A pesquisa psicogenética focada na escrita trouxe diversas contribuições. Entretanto, a transposição didática para a sala de aula aconteceu de modo superficial e equivocado, muitas vezes dando margem a propostas que se distanciavam por completo dos postulados da investigação liderada por Ferreiro. Faz-se necessário compreender melhor essa problemática para entender os rumos tomados pelo ensino da escrita a partir daqui.

\subsection{A TRANSPOSIÇÃO DIDÁTICA: A PSICOGÊNESE EM SALA DE AULA}

Tão logo as contribuições da pesquisa psicogenética chegaram ao Brasil, ao final da década de 70, rapidamente houve, por parte de escolas e de órgãos governamentais, tentativas de incorporá-las às salas de aula. No entanto, tratava-se de um processo de mudança complexo; mais do que de difundir uma inovação pedagógica ou metodológica, o desafio era assimilar um novo olhar sobre a aprendizagem da escrita e sobre o sujeito aprendiz, capaz de trilhar processos singulares para se apropriar desse objeto. Era fundamental que os professores pudessem, de fato, compreender as bases da pesquisa, mas não foi o que efetivamente ocorreu.

Em algumas circunstâncias, porém, na ânsia de resolver o problema do desempenho historicamente ruim dos alunos em escrita/leitura, desafio que a escola não tem sabido enfrentar com competência, registraram-se tentativas apressadas e, por vezes, irresponsáveis de transformar em método os resultados de uma pesquisa academicamente séria. (ABAURRE; FIAD; MAYRINKSABINSON, 1997, p. 17)

Em linhas gerais, os momentos conceituais identificados pelas pesquisadoras foram tomados como parte mais relevante do trabalho e levados para a sala de aula: era preciso "fazer" com que as crianças passassem de um estágio a outro. Mas esse "fazer” não havia sido explicitado na pesquisa. Ferreiro e Teberosky ocuparam-se do processo psicogenético e não expuseram os "passos" como etapas necessárias a ser seguidas pelos professores. Acostumados a métodos fechados para ensinar as crianças a escrever, os professores não puderam compreender a parte que lhes cabia para na reformulação do ensino da escrita. Os momentos conceituais tornaram-se "camisas de força” para as crianças, que passaram a ser classificadas e inseridas em 
cada um deles. Para conhecer o aluno em seu processo bastava oferecer-lhe a possibilidade de uma produção livre, isenta de qualquer intervenção do adulto ou de colegas, e identificar nela traços típicos de um dos momentos. O processo de conceitualização da escrita transformava-se em uma sucessão de etapas estanques e pré-determinadas pela escola: o sujeito pré-silábico precisa escrever silabicamente, em seguida aprender a escrever de forma silábico-alfabética e, finalmente, apresentar uma escrita alfabética. Interpretar o processo desse modo fez com que, no âmbito escolar, os momentos conceituais se configurassem, muitas vezes, como estágios de progressão curricular, atividades pontuais no planejamento anual ou até critérios de mensuração da aprendizagem.

Em conseqüência dessa transposição da pesquisa psicogenética para a sala de aula e da ausência de construções didáticas (apoiadas de fato nesse novo olhar sobre a aprendizagem e o objeto de ensino), as contribuições da Psicogênese ganharam vertentes distintas nas salas de aula. Em algumas situações, o ensino da escrita tornou-se um fazer somente do aluno. Afinal, se o processo de construção de conhecimentos é individual e o aprendiz sujeito de seu próprio percurso, entendeu-se que qualquer intervenção poderia comprometer os avanços dos alunos. O contato com materiais escritos - livros, gibis, cartazes com poemas e parlendas ou tarjetas com palavras, por exemplo - era favorecido e a experiência da criança com os mesmos tida como suficiente para que avançasse conceitualmente.

Em outras situações, o trabalho com os métodos de ensino se manteve, pois esses davam realmente segurança ao professor: na ânsia de controlar precisamente o processo de aprendizagem, o docente sabia que passos trilhar para ensinar os alunos a escrever. Em tais casos, por vezes, propostas de escritas tidas como espontâneas eram feitas para que se elaborasse um mapeamento da classe: quantos alunos em cada "etapa” conceitual. Recorrer a esse tipo de classificação parecia garantir à sua prática uma dimensão supostamente renovadora, que servia para mascarar a resistência de um ensino empirista e da didática tipicamente “cartilhesca”.

Mortatti (2000, p. 286) menciona, inclusive, o surgimento de um novo método atribuído às idéias psicogenéticas:

[...] disseminou-se [...] um método eclético de novo tipo. Resultando da combinação de métodos tradicionais com as implicações pedagógicas das pesquisas de Ferreiro, esse "método" baseia-se no diagnóstico e posterior classificação "construtivista" dos alfabetizandos em "pré-silábicos”, "silábicos" e "alfabéticos", a partir dos quais o professor deve desenvolver um "trabalho" 
que respeita a realidade da criança e seu ritmo de construção do conhecimento, de preferência com textos e por meio deles. (grifos da autora)

Poucas efetivamente foram as instituições que decidiram se aprofundar na compreensão do que a Psicogênese trazia e nas conseqüências que tais descobertas deveriam ter em sala de aula. Ainda hoje, é possível encontrarmos intervenções pedagógicas equivocadas, como as tentativas de classificar os alunos, e até a ausência de intervenções planejadas e dirigidas, práticas supostamente apoiadas nas idéias da psicogênese.

Hoje em dia, persistem os problemas associados ao ensino da escrita. As mudanças conceituais e metodológicas necessárias no âmbito do ensinar ainda não ocorreram em massa e muito se faz ou se deixa de fazer em nome de uma Psicogênese que sequer chegou a ser compreendida por boa parte dos educadores. Analisar algumas das razões que impedem tais mudanças pode favorecer a entendimento do quadro atual no campo da alfabetização.

Uma dessas razões está na intenção, comum no campo da Educação, de transformar pesquisas básicas no campo da Psicologia em práticas de sala de aula. Reproduzir as perguntas feitas nas situações de entrevista e as situações de produção escrita propostas pelos entrevistadores torna-se prática comum nas “classes de alfabetização”. Entretanto, é preciso ressaltar que "não existem situações de aprendizagem que sejam produtivas em qualquer circunstância” (WEISZ, 1988, p. 42). Tampouco se pode afirmar que sejam favoráveis, igualmente, para todas as crianças e que, por conseqüência, promoverão avanços idênticos.

A esse respeito, vale lembrar as palavras da própria Emilia Ferreiro (1990, p. 35-36) para explicar o desajuste na transposição da pesquisa para a prática pedagógica:

Há uma diferença evidente entre as necessidades de uma pesquisa básica e as de uma prática educativa: as certezas na pesquisa básica são sempre poucas e o pesquisador sabe que se tratam de verdades provisórias; no âmbito educativo, em contrapartida - por razões que nem sempre têm a ver com os próprios educadores, mas sim com o contexto no qual se desenvolve a ação e com as expectativas sociais a ela vinculadas -, esperam-se certezas, e não verdades provisórias.

Ora, a pesquisa psicogenética mais ampla, desenvolvida por Piaget e seus colaboradores, ou a pesquisa psicogenética centrada na língua jamais tiveram por propósito abarcar toda e qualquer questão que envolva o processo de ensino-aprendizagem. 
Uma outra motivação para as dificuldades de transposição didática está no fato de que a escrita é um objeto de caráter sócio-cultural que transcende o conhecimento sobre o princípio alfabético. Saber escrever fora da escola não significa apenas saber escrever em consonância com as normas do sistema de escrita. Por esse motivo, cabe ao professor conhecer o objeto "escrita" em toda a sua complexidade, uma vez que a competência de ler e escrever abrange o

[...] conhecimento da língua mas também, e principalmente, um outro tipo de conhecimento, o conhecimento sobre a língua que cada vez mais se mostra fundamental para o alfabetizador. O que a psicogênese descreve é apenas uma das questões em jogo: a aquisição da base alfabética da escrita. Uma questão fundamental mas não a única. (WEISZ, 1998, p. 45, grifos da autora)

Há outros aspectos a ser considerados se a preocupação da escola está em formar competentes usuários da língua escrita. A escola e o professor não podem deixar de lado “[...] temas como as diferenças entre a língua que se fala e a que se escreve, as estratégias de leitura, [...], o papel da ortografia, os mecanismos de coesão textual etc.” (Ibidem, p. 45)

A escrita, como objeto de caráter sócio-cultural, não pode se reduzir a um modelo tipicamente escolar. No ensino, um processo de transposição didática deve de fato ser promovido para que esse objeto sofra certas transformações e adaptações e se torne um conteúdo a ser apropriado. Mas essa transposição implica assegurar que o objeto de ensino não se desconfigure; não se pode ter objetos de ensino na escola sem relação com o que são fora dela. Do contrário, formaremos usuários da escrita aptos a atuar na escola, mas pouco competentes para se comunicar por intermédio dos textos especialmente fora desse âmbito institucional.

Nas palavras de Lerner (2002, p. 35):

\begin{abstract}
A transposição didática é inevitável, mas deve ser rigorosamente controlada. É inevitável porque o propósito da escola é comunicar o saber, porque a intenção de ensino faz com que o objeto não possa aparecer exatamente da mesma forma, nem ser utilizado da mesma maneira que é utilizado quando essa intenção não existe [...]. Deve ser rigorosamente controlada, porque a transformação do objeto - da língua escrita e das atividades de leitura e escrita, em nosso caso - teria que se restringir àquelas modificações que, realmente, são inevitáveis.
\end{abstract}

Vale salientar novamente que, quando se toma a psicogênese da língua como único referencial ou quando se busca transformar ações de pesquisadores (sobretudo quando se está 
tratando de pesquisas básicas) em ações didáticas, aspectos cruciais, sejam relativos ao objeto de conhecimento, sejam relativos ao ensino, acabam por ser desconsiderados.

É todo um conjunto de referenciais explicativos que precisa ser conhecido pelo professor para fundamentar sua prática pedagógica e, mais especificamente, para ensinar a ler e a escrever. Pelo que se destacou até esse ponto, não se trata de "utilizar" a psicogênese em sala de aula, tampouco utilizar receitas e instruções apresentadas pelos métodos fechados, pois esses estão longe de abranger as peculiaridades do processo de ensino-aprendizagem.

Assim, parece que precisamos de teorias que forneçam instrumentos de análise e reflexão sobre a prática, sobre como se aprende e como se ensina; teorias que podem e devem enriquecer infinitamente com contribuições acerca do como influem, nessa aprendizagem e no ensino, as variáveis que interferem [...], mas que possam funcionar como catalisador geral de algumas perguntas básicas que todos nós professores nos colocamos. [...]

As teorias, nossos marcos referenciais, se mostrarão adequadas na medida em que possam dar alguma explicação sobre as interrogações [...], mas também na medida em que essa explicação permita articular as diversas propostas em um referencial coerente, tanto em nível intermo como externo (COLL; SOLÉ, 1998, p. 12).

A psicogênese oferece contribuições de grande relevância no campo do ensino da escrita e da leitura. Isso é inegável. Mas, como já se evidenciou, não se trata de uma explicação onipotente nem excludente. Outras contribuições teóricas, advindas da Psicologia, dos estudos sobre a Linguagem, da Lingüística ou da Sociologia, por exemplo, são igualmente necessárias para que o professor amplie seus conhecimentos e tenha um amplo referencial

para contextualizar e priorizar metas e finalidades; para planejar a atuação; para analisar seu desenvolvimento e modificá-lo paulatinamente, em função daquilo que ocorre e para tomar decisões sobre a adequação de tudo isso (Ibidem, p. 12).

Diante das especificidades da apropriação da escrita e das intervenções que precisam ser potencializadas no âmbito escolar para favorecer esse processo, cabe destacar outras contribuições teóricas que, ao lado dos estudos psicogenéticos, permitem uma visão mais ampla e aprofundada do papel da instituição e do professor.

No tópico a seguir, será feita uma explanação mais geral sobre a concepção construtivista para que se possa, mais adiante, resgatar sua relevância junto ao ensino da língua escrita. 


\subsection{A CONCEPÇÃO CONSTRUTIVISTA: UM CONJUNTO DE APORTES TEÓRICOS}

Para além do impacto conceitual e pedagógico que os estudos psicogenéticos tiveram sobre a alfabetização, é preciso considerar o seu efeito sobre a concepção de aprendizagem, o papel do professor e as diretrizes de ensino. Colocar como sujeito desse processo o aluno e não o professor ou o método representou realmente uma ruptura também na concepção de ensino.

Na década de 80, sobretudo em função da divulgação das pesquisas psicogenéticas e da necessidade de se repensar a prática de ensino, o referencial construtivista passou a ganhar proeminência nos meios escolares. Muitos dos postulados da "escola nova” foram retomados, porém evidenciando ainda mais os processos de aprendizagem e a importância de revisar a maneira de se conceber o sujeito que aprende e os próprios objetos de conhecimento.

Mas, posicionar-se como uma escola ou um professor construtivista nesse período reduzia-se, inúmeras vezes, à aplicação da psicogênese estritamente no ensino da língua escrita e, até, em outras áreas do conhecimento, à reprodução em sala de aula das mesmas situaçõesproblema elaboradas por Piaget ao longo de suas pesquisas. As tentativas diretas de aplicação dos estudos psicogenéticos na sala de aula foram intensas nesse início de apropriação das novas idéias; pareciam se instaurar como uma alternativa "salvacionista" e deixavam de ponderar a impossibilidade de "um casamento perfeito" entre os conhecimentos acadêmicos e "as demandas do ensino” (BELINTANTE, 2005, p. 66).

Por que a transposição direta das pesquisas básicas para a prática pedagógica, a reprodução das experiências de Piaget ou a aplicação estrita da psicogênese são insuficientes para a constituição de uma escola pautada nos princípios construtivistas?

É certamente imprescindível destacar a influência da teoria genética desenvolvida por Piaget e colaboradores na elaboração do referencial construtivista. A própria formulação de que “o ato de conhecimento consiste em uma apropriação progressiva do objeto pelo sujeito” (COLL, 1987, p. 186) se configura como fundamental contribuição e parece diretamente ligada à aprendizagem escolar. A denominação “construtivismo” advém, justamente, da importância que se atribui à atividade mental do sujeito em seu processo de construção de conhecimentos (SECRETARIA DA EDUCAÇÃO FUNDAMENTAL, 1997). Porém, não se pode adotar construtivismo e teoria piagetiana como sinônimos. 
Em vez de tomar esta ou aquela parte ou conceito da teoria - os estádios de desenvolvimento, a capacidade de estruturação operatória, as provas operatórias, o princípio da atividade auto-estruturante, etc - e aplicá-los a este ou aquele aspecto da aprendizagem escolar - objetivos, conteúdos, avaliação, metodologia de ensino, etc. - perguntar-se até que ponto a explicação global do processo de construção do conhecimento proporciona um quadro teórico para a análise deste processo de aquisição de conhecimentos com características próprias que é a aprendizagem escolar. (COLL, 1987, p. 191)

Embora sua pesquisa seja fundamental para a formulação dos princípios construtivistas, deve-se compreender que, enquanto investigador, Piaget, assim como seus discípulos, tinha como foco analisar a gênese do conhecimento, sem o propósito de esgotar as explicações sobre os processos de aprendizagem. Também importa situar que Piaget não teve interesse em abordar questões estritamente educacionais em suas pesquisas e publicações, e sua teoria, assim como qualquer outra, revela uma série de restrições se for reputada como único "instrumento de análise” para explicar e justificar tudo o que ocorre no âmbito escolar (Ibidem, p. 191).

Do ponto de vista histórico e conceitual, entender que a teoria psicogenética é só uma das importantes contribuições a compor o referencial construtivista realmente representa uma porta de entrada para outros marcos teóricos, de igual valor, que aumentam as possibilidades de compreensão das questões inerentes à tarefa de aprender e ensinar na escola.

O referencial construtivista, portanto, não se limita a uma única teoria científica ou sequer trata de uma área de conhecimento em especial. “A perspectiva construtivista na educação é configurada por uma série de princípios explicativos do desenvolvimento e da aprendizagem humana que se complementam [...]” (SECRETARIA DE EDUCAÇÃO FUNDAMENTAL, 1997, v. 1, p. 50).

A concepção construtivista oferece ao professor um referencial para analisar e fundamentar muitas das decisões que toma no planejamento e no decorrer do ensino [...]. Paralelamente, proporciona critérios para compreender o que acontece na sala de aula. [...]

A concepção construtivista é um referencial útil para a reflexão e tomada de decisões compartilhada, que pressupõe o trabalho em equipe de uma escola; como referencial, é ainda mais útil quando esse trabalho for articulado em torno das grandes decisões que afetam o ensino e que estão sistematizadas nos Projetos Curriculares das Escolas (COLL; SOLÉ, 1998, p. 25, grifos dos autores). 
Enquanto aporte para a prática e a reflexão inerente à tarefa do professor e da escola, a concepção construtivista não pode ser vista de um modo restrito, já que se situa como um amplo referencial para que se entenda as situações de ensino e aprendizagem, favorecendo também a compreensão das relações estabelecidas na instituição escolar, local onde se destaca com maior potencialidade.

A configuração do marco explicativo construtivista para os processos de educação escolar deu-se, entre outras influências, a partir da psicologia genética, da teoria sociointeracionista e das explicações da atividade significativa. [...]

A abordagem construtivista integra, num único esquema explicativo, questões relativas ao desenvolvimento individual e à pertinência cultural, à construção de conhecimentos e à interação social. Considera o desenvolvimento pessoal como o processo mediante o qual o ser humano assume a cultura do grupo social a que pertence. Processo no qual o desenvolvimento pessoal e a aprendizagem da experiência humana culturalmente organizada, ou seja socialmente produzida e historicamente acumulada, não se excluem nem se confundem, mas interagem. (SECRETARIA DA EDUCAÇÃO FUNDAMENTAL, 1997, P. 50 e 52)

Trata-se de um referencial complementado por diferentes ciências (como a própria Psicologia, a Lingüística e a Sociologia) e que permite integrar posições que não contraponham a apropriação dos objetos sócio-culturais ao desenvolvimento individual.

Dentre os marcos teóricos do construtivismo, a pesquisa realizada por Vygotsky vem ganhando maior evidência nos meios acadêmicos, trazendo implicações para o entendimento das práticas escolares, o que inclui, aqui, o ensino da língua escrita. Da mesma maneira, as contribuições de Bakhtin no campo da linguagem não podem ser deixadas de lado, sobretudo quando se trata de compreender a questão do ensino, razão pela qual merecem ser brevemente consideradas nesse capítulo.

1.4.1. Vygotsky: a interação social e a apropriação da escrita

Os estudos de Vygotsky e Bakhtin inserem-se em um contexto sócio-histórico bastante similar. Investigadores russos e partidários da corrente marxista, nascidos respectivamente em 1896 e 1895, viveram em um período revolucionário (Revolução Russa em 1917) e de transição naquele país, tendo sido, inclusive, perseguidos pelo regime vigente. Ambos desenvolveram pesquisas e textos influenciados pelo entusiasmo e interesse na criação de uma nova sociedade, uma motivação favorecida pelo clima de efervescência política na Rússia. 
Vygotsky dedicou-se, entre outros aspectos, às questões da Psicologia e também da Educação. Suas pesquisas trazem postulados intrinsecamente marcados por uma abordagem histórico-cultural, de extrema importância para que também se possa ampliar a compreensão sobre o papel da escola e sobre o próprio processo de aprendizagem. Vygotsky realizou suas análises e pautou suas argumentações valorizando características peculiares à espécie humana e à sua capacidade de transformar e de se transformar, nos mais diversos contextos históricos e culturais.

Realizar-se-á, nesse trecho, uma breve exposição de algumas de suas idéias, principalmente as que interessam para a presente pesquisa, a fim de favorecer o entendimento sobre o impacto que tiveram no âmbito escolar. Também aqui é preciso certa precaução, pois não se trata de extrair aspectos pontuais de sua vasta teoria e estabelecer uma transposição direta para os fenômenos da aprendizagem escolar. Do mesmo modo, não é o caso de confrontar os estudos de Vygotsky e com os de Piaget nem de eleger um ou outro teórico como referência, ainda que se reconheça entre eles pontos de divergências, por vezes também explicados pelos pontos de partida e pelos diferentes enfoques que imprimiram em suas investigações.

Em linhas gerais, Piaget concentrou-se no desenvolvimento individual dos sujeitos, enquanto Vygotsky atuou sob o viés da dimensão social na formação do sujeito. Infelizmente, o confronto direto entre eles não ocorreu, caso contrário, como destacou Piaget: “[...] se tivesse sido possível uma aproximação, poderíamos ter chegado a nos entender sobre diversos pontos” (PIAGET, apud OLIVEIRA, 1997, p. 53²).

Mais do que colocados em oposição, esses "precisam ser estudados buscando uma melhor compreensão de suas teorias e de seus possíveis desdobramentos no campo educacional” (FREITAS, 1994, p. 16).

Além disso, estudos mais recentes (entre os quais os de Michael Cole, 1981a e 1981b) ${ }^{3}$, superam essa controvérsia e propõem um esquema explicativo que integra "processos de

\footnotetext{
${ }^{2}$ Texto original: PIAGET, J. Comentários sobre las observaciones críticas de Vygotsky. In: VYGOTSKY, L.S. Pensamiento y lenguaje. Buenos Aires: La pleyade, 1981.

${ }^{3}$ COLE, M. Society, mind and development. CHIP Report 106, Laboratory of Comparative Human Cognition, University of California, San Diego, September-1981a.

COLE, M. The zone of proximal development: where culture and cognition creat each other. CHIP Report 106, Laboratory of Comparative Human Cognition, University of California, San Diego, September-1981b.
} 
desenvolvimento individual e o aprendizado da experiência humana culturalmente organizada” (COLL, 1996, p. 40).

Indiscutivelmente, a educação tem muito a se beneficiar com o legado teórico desses dois grandes mestres da Psicologia e, de modo mais específico, importa registrar contribuições de ambos para o ensino da língua materna.

A partir dessas considerações, o papel atribuído por Vygotsky às interações sociais, merece ser aprofundado aqui, sobretudo para que se entenda a relação entre aprendizes e entre aprendizes e o professor no ambiente escolar. Para ele, o desenvolvimento do sujeito tem início nas interações sociais; o sujeito é mesmo “um resultado das formas de relação” (Vygotsky, 1991) que estabelece com seu meio. Sem negar o caráter individual - relevado por Piaget - da gênese do pensamento humano e da construção das funções mentais superiores (entre as quais a formação de conceitos, a memória, a atenção etc.), Vygotsky atribui um caráter amplamente social a esses processos. Para ele:

Um processo interpessoal é transformado num processo intrapessoal. Toda as funções no desenvolvimento da criança aparecem duas vezes: primeiro, no nível social, e, depois, no nível individual; primeiro, entre pessoas (interpsicológica), e, depois, no interior da criança (intrapsicológica) [...] A transformação de um processo interpessoal num processo intrapessoal é o resultado de uma longa série de eventos ocorridos ao longo do desenvolvimento (Ibidem, p. 64, grifos do autor).

Vygotsky vai adiante nessa explicitação, reafirmando o viés interativo do processo de aprendizagem:

\footnotetext{
O aprendizado humano pressupõe uma natureza social específica e um processo através do qual as crianças penetram na vida intelectual daquelas que as cercam. As crianças podem imitar uma variedade de ações que vão muito além dos limites de suas próprias capacidades. Numa atividade coletiva ou sob orientação de adultos, as crianças são capazes de fazer muito mais coisas (VYGOTSKY, 1991, p. 99).
}

Não se pode afirmar que a importância conferida ao meio social por Vygotsky esteja em desacordo com as concepções piagetianas. Muito pelo contrário, embora não tome como tema principal de suas investigações, Piaget, como já se evidenciou, reconhece igualmente que o desenvolvimento humano subordina-se a determinados fatores, entre os quais 
os fatores de transmissão ou de interação sociais, que intervêm desde o berço e desempenham um papel de progressiva importância, durante todo o crescimento, na constituição dos comportamentos e da vida mental. Falar de um direito à educação é pois, em primeiro lugar, reconhecer o papel indispensável dos fatores sociais na própria formação do indivíduo. (PIAGET, 1978, p. 29)

Ao discorrer sobre as especificidades do papel da escola, Piaget (Ibidem, p. 33) reiterou também o papel das relações sociais:

Proclamar que toda pessoa tem o direito à educação [...] é [...] afirmar que o indivíduo não poderia adquirir suas estruturas mentais mais essenciais sem uma contribuição exterior, a exigir um certo meio social de formação, e que em todos os níveis (desde os mais elementares até os mais altos) o fator social ou educativo constitui uma condição do desenvolvimento.

Em síntese, pode-se dizer que, para ambos os teóricos, a questão da interação com o meio tem sua importância. Assim, ao considerar que a construção de conhecimentos e a apropriação de objetos sócio-culturais implicam um processo de internalização individual, mas que têm suas bases nas "relações reais entre indivíduos humanos", é preciso, a partir do referencial construtivista, ponderar que, embora os percursos de aprendizagem e desenvolvimento sejam singulares, só são realmente possíveis na interação entre os sujeitos no âmbito dos processos sócio-culturais.

Nos postulados de Vygotsky, a aprendizagem, enquanto processo de internalização, se dá pela zona de desenvolvimento proximal: partindo-se do que o sujeito já se apropriou e, oferecendo-lhe ajuda, propõe-se "o acesso não somente ao que já foi atingido através do desenvolvimento, como também àquilo que está em processo de maturação” (VYGOTSKY, 1991, p. 64, grifos do autor). É dessa maneira que, durante muito tempo, inclusive em situações escolares, a resolução de determinados problemas por um aluno só é viável com a mediação de outros, sejam esses colegas aprendizes, seja o professor ou, por vezes, a própria configuração da tarefa ou a presença de recursos que favoreçam sua realização.

Não se pode atestar que, em estágios mais elementares do percurso cognitivo, chegar à ou aproximar-se da solução do problema seja algo impossível para o sujeito aprendiz; ao contrário, é preciso levar-se em conta que, na especificidade de cada momento, é a interação com 
“outros significativos” que favorecerá a progressiva conquista. No processo desse aprendiz, resolver o problema, agora, é uma tarefa cada vez mais possível em âmbito intrapessoal. Gradualmente, vai se constituindo em um saber internalizado e apropriado pelo sujeito.

A interação, assim compreendida, é essencial às situações de aprendizagem, inclusive às que se instauram dentro da escola. Na interação entre aprendizes mais experientes e colegas menos experientes, apenas para citar uma possibilidade, os primeiros podem reorganizar os seus saberes e até generalizá-los, enquanto os demais podem conhecer novas formas de resolução de um problema - quaisquer que sejam elas, como a escrita de uma palavra, confrontadas com seu saber e experimentadas. Em ambos os casos, a interação favorece operações que propiciam aos alunos refletir sobre algo que ainda não fazem com total autonomia. O trabalho em parcerias, e em diferentes parcerias, com a missão de lidar com uma determinada tarefa escolar e organizada de modo a se chegar a consensos e decisões, permite uma circulação de informações de diferentes tipos, envolvendo fatos, conceitos e princípios, procedimentos e atitudes. ${ }^{4}$ É importante salientar que as crianças podem aprender entre si por vezes muito mais do que com seus professores. Apesar da interação com o professor ser crucial, o trabalho entre pares ou em pequenos grupos de crianças parece ser insubstituível na configuração de um ensino que considere a aprendizagem como construção individual de conhecimentos e, ao mesmo tempo, partilhada.

Até esse ponto, discutiu-se o significado da interação nas situações de aprendizagem, conforme os postulados de Vygotsky. Porém, a fim de avançar nas reflexões apresentadas aqui, é preciso se destacar também suas contribuições para a compreensão da aprendizagem da escrita.

Vygotsky conferiu um papel crucial à linguagem em sua relação dialética com o pensamento e dedicou-se inclusive, com a colaboração de seu discípulo Luria, a compreender o processo de apropriação da escrita.

Apesar de suas pesquisas antecederem, em aproximadamente 50 anos, as realizadas por Ferreiro e Teberosky, há certa similaridade entre elas, sobretudo na postulação da escrita como um sistema de representação, cuja apropriação tem início muito antes do ingresso da criança na

\footnotetext{
${ }^{4}$ Importa distinguir, em linhas gerais, esses tipos de informações ou conteúdos, como define Zabala (1998). Para ele, os fatos englobam acontecimentos, dados ou fenômenos de natureza concreta. Os conceitos são conjuntos de "fatos, objetos ou símbolos que têm características comuns, e os princípios se referem às mudanças que se produzem num fato, objeto ou situações em relação ao outros fatos, objetos ou situações” (p. 42). Já os procedimentos são conjuntos de ações seriadas e com um propósito específico, como as técnicas, por exemplo. E finalmente, o conjunto de conteúdos atitudinais abrange normas, valores e atitudes.
} 
escola. Em decorrência de tal concepção, Vygotsky (1991, p. 119) também teceu críticas às práticas escolares usuais no ensino da escrita:

Ao invés de se fundamentar nas necessidades naturalmente desenvolvidas das crianças, e na sua própria atividade, a escrita lhes é imposta de fora, vindo das mãos dos professores. Essa situação lembra muito o processo de desenvolvimento de uma habilidade técnica [...].

Luria, a partir de estudos experimentais, encontrou certos estágios categorizando desenhos e produções escritas de crianças que não dominavam o sistema de representação. Tratando sobre a diversidade das respostas infantis, Vygotsky (Ibidem, p. 120-121) comentou:

\begin{abstract}
A história do desenvolvimento da linguagem escrita nas crianças é plena dessas descontinuidades. Às vezes, a sua linha de desenvolvimento parece desaparecer completamente, quando, subitamente, como que do nada, surge uma nova linha; e a princípio parece não haver continuidade alguma entre a velha e a nova. Mas somente a visão ingênua de que o desenvolvimento é um processo puramente evolutivo, envolvendo nada mais do que acúmulos graduais de pequenas mudanças e uma conversão gradual de uma forma em outro, pode esconder-nos a verdadeira natureza desses processos.
\end{abstract}

Nessas pesquisas, Luria e Vygotsky procuraram, primordialmente, identificar as funções da escrita identificadas pelas crianças, diferenciando-se das investigações organizadas por Ferreiro, baseadas na natureza interna do processo de apropriação da escrita. É por essa razão que se pode

[...] dizer que Luria trabalha com a criança da fase pré-silábica de Ferreiro, isto é, com a criança que ainda não percebeu que a escrita representa o som da fala, que está operando na construção da compreensão da utilidade e das funções da escrita. Quando a criança ingressa na fase silábica de Ferreiro, ela já está além das considerações de Luria (OLIVEIRA, 1995, p. 67).

A despeito das diferenças entre os dados obtidos, justamente pelas pesquisas apresentarem focos diversos e serem promovidas em tempos e espaços culturais bastante diferentes, contribuições pedagógicas podem ser extraídas de ambos os estudos.

Primeiramente, tem-se a constatação de que a escrita, assim como outros objetos de conhecimento, não é alvo da análise infantil somente depois do ingresso na escola, mas é observada muito antes, conforme apontam esses investigadores (FERREIRO; TEBEROSKY, 
1985; VYGOTSKY, 1991; LURIA; VYGOTSKY, LEONTIEV, 1991). É por essa razão até que Vygotsky chegou a defender a transferência do "ensino da escrita para a pré-escola" (VYGOTSKY, 1991, p. 132).

Uma segunda consideração comum às referidas pesquisas consiste na necessidade da escrita ser ensinada não como uma técnica, mas de acordo com as funções sociais que possui. As crianças precisam aprender a ler e escrever atribuindo significados reais a essas tarefas:

[...] a escrita deve ser incorporada a uma tarefa necessária e relevante para a vida. Só então poderemos estar certos de que ela se desenvolverá não como hábito de mão e dedos, mas como uma forma nova e complexa de linguagem. (VYGOTSKY, 1991, p. 133)

Pode-se afirmar, portanto, que as contribuições de Vygotsky, e também de seus estudos com Luria, são cruciais para que se compreenda o ensino da linguagem em âmbito social, aspecto que ganha ainda mais importância se considerarmos o próprio ambiente escolar e os inúmeros intercâmbios que ali podem ser favorecidos.

Avançando nas considerações acerca da dimensão social da escrita, tão relevante para que se assimile o processo de alfabetização enquanto apropriação de um objeto cultural, importa enfocar a contribuição de Bakhtin, o que será feito no próximo item.

\subsubsection{Bakhtin: a interlocução na constituição da língua e do sujeito}

Contrariando a idéia de que existe uma língua instituída, pronta e acabada, que paira acima dos falantes, Bakhtin defende a concepção da linguagem como algo essencialmente dialógico, isto é, que se constitui na produção contextualizada e interlocutiva da fala e da escrita. Por essa razão, falar e escrever só se tornam importantes em face da necessidade de comunicação e de expressão, o que torna a interação social inerente à própria linguagem. Os enunciados emitidos nas interlocuções ganham sentidos particulares, atribuídos por seus emissores e pelos receptores ativos. Explicando essa posição bakhtiniana, Freitas (2003, p. 136) afirma:

O sentido exige uma compreensão ativa, mais complexa, em que o ouvinte, além de decodificar, relaciona o que está sendo dito com o que ele está presumindo e prepara uma resposta ao enunciado. Compreender não é, portanto, simplesmente decodificar, mas supõe toda uma relação recíproca entre falante e ouvinte, ou uma relação entre os ditos e os presumidos. 
Bakhtin (Ibidem, p. 189-290) assume ainda que:

A língua como sistema possui, evidentemente, um rico arsenal de recursos lingüísticos - lexicais, morfológicos e sintáticos - [...] mas todos esses recursos enquanto recursos da língua são absolutamente neutros em relação a qualquer avaliação real determinada. [...] As palavras não são de ninguém, em si mesmas nada valorizam, mas podem abastecer qualquer falante e os juízos de valor mais diversos $[\ldots]$.

De acordo com esse pesquisador, o discurso oral e escrito criado pelos sujeitos, “dependendo das diversas funções da linguagem e das diferentes condições e situações de comunicação, é de natureza diferente e assume formas várias” (BAKHTIN, 2003, p. 275).

Faz-se importante destacar que o mesmo papel que atribui à linguagem falada, Bakhtin designa às produções escritas, as quais, igualmente, devem ser entendidas como processos de interlocução entre sujeitos. Escrever supõe, desse modo, interação, seja com esse objeto de conhecimento que é a língua escrita - pela possibilidade de reconstruí-la nas diferentes interlocuções que estabelecemos -, seja com os outros envolvidos nesse processo: outros sujeitosautores e sujeitos-leitores.

Geraldi (1996, p. 19), comenta que, a partir das idéias de Bakhtin,

[...] entende-se que o sujeito se constitui como tal à medida que interage com os outros, sua consciência e seu conhecimento do mundo resultam como 'produto sempre inacabado' deste mesmo processo no qual o sujeito internaliza a linguagem e constitui-se como ser social [...]. Isto implica que não há um sujeito dado, pronto, que entre em interação, mas um sujeito se completando e se constituindo em suas falas e nas falas dos outros.

Avançando nessa reflexão e focando-se nos aspectos concernentes à aprendizagem, Geraldi (1997, p. 17) destaca que:

A aprendizagem da linguagem é já um ato de reflexão sobre a linguagem: as ações lingüísticas que praticamos nas interações em que nos envolvemos demanda esta reflexão, pois compreender a fala do outro e fazer-se compreender pelo outro tem a forma do diálogo: quando compreendemos o outro, fazemos corresponder à sua palavra uma série de palavras nossas; quando nos fazemos compreender pelos outros, sabemos que às nossas palavras eles fazem corresponder uma série de palavras suas. (grifos do autor) 
A produção de textos entendida como ação discursiva, de acordo com Geraldi (1997, p. 135) também precisa ganhar maior importância no âmbito escolar.

Considero a produção de textos (orais e escritos) como ponto de partida (e ponto de chegada) de todo o processo de ensino-aprendizagem da língua. [...] Sobretudo, é porque no texto que a língua - objeto de estudos - se revela em sua totalidade quer enquanto conjunto de formas e de seu reaparecimento, quer enquanto discurso que remete a uma relação intersubjetiva constituída no próprio processo de enunciação marcada pela temporalidade e suas dimensões.

No campo da aprendizagem e do ensino da linguagem (oral e escrita), inúmeras reflexões ainda podem ser feitas se levarmos em conta as idéias de Vygotsky, Bakhtin e do próprio Piaget, autores que se destacam como importantes referências tanto para pesquisas científicas e como também para a revisão das práticas escolares.

A partir dos estudos psicogenéticos sobre a escrita, novas investigações - já incorporando considerações de outros teóricos, entre os quais Vygotsky - sobre os conceitos e processos envolvidos na apropriação da escrita e da linguagem, de forma mais ampla, vêm sendo realizadas. A noção de "literacy", traduzida como letramento, foi se constituindo e ganhando espaço nos estudos brasileiros. Gradativamente, reflexões sobre a necessidade de formação efetiva de usuários competentes da escrita passou a ocupar os debates acadêmicos e, aos poucos, também a ocupar discussões no interior da própria instituição escolar.

O próximo tópico tem por finalidade explicitar mais detalhadamente as idéias subjacentes às noções de letrar e alfabetizar, assim como tratar da transposição didática ocorrida a partir daí para enfocar, mais uma vez, as interpretações reducionistas e equivocadas presentes nos discursos como ou nas práticas pedagógicas.

\subsection{LETRAMENTO, ALFABETIZAÇÃO E NOVOS PROCESSOS DE TRANSPOSIÇÃO DIDÁTICA}

A pesquisa psicogenética centrada na língua não tinha como propósito, assim como acontece com o necessário recorte de quaisquer investigações, envolver todas as especificidades do processo de construção do sujeito como um usuário competente e autônomo da escrita. Além de compreender os princípios geradores do nosso sistema de escrita, o sujeito aprendiz deve se apropriar de suas formas de uso: em que circunstâncias, por quais razões e por meio de que textos 
deve escrever para comunicar o que deseja? A mensagem escrita pode assumir diferentes formas dependendo das escolhas feitas para cada uma dessas questões e também em função dos destinatários aos quais se dirige.

A entrada da psicogênese da língua em sala de aula, mesmo equivocada e fragmentada em inúmeros casos, como já foi descrito, permitiu que os educadores pudessem, ao menos, colocar em xeque as práticas alfabetizadoras mais tradicionais. Entender a aprendizagem da escrita como um processo de construção conceitual trouxe à tona uma nova vertente sobre esse objeto, até então tido somente como uma habilidade a ser adquirida. A despeito desse avanço, a prática pedagógica da escrita, voltada para fins estritamente escolares e tantas vezes carente de reflexões críticas, permaneceu em formas de ensino limitadas ao domínio de um “código” e de regras do sistema: ainda que relevando as concepções próprias das crianças e os diferentes momentos conceituais no processo de apropriação da escrita, o trabalho com os textos continuava em segundo plano, aguardando esses pequenos aprendizes dominarem a escrita para então se aventurarem como escritores. Na maior parte das vezes, o efetivo uso da língua era proposto apenas pelo viés da leitura, tendo o professor como mediador, somente lendo para elas os textos de circulação social. Ver as crianças como produtoras de textos, como escritoras de fato não era algo possível para muitos dos educadores. Com a psicogênese, descobriu-se que as crianças pensam sobre a escrita, mas isso não foi tomado em uma amplitude maior no mundo escolar: para os professores, as crianças tinham idéias somente sobre como grafar as palavras, mas não sobre como se comunicar por meio da escrita.

No contexto brasileiro, especialmente ao final da década de 80, ficava cada vez mais notória a amplitude e complexidade do problema da alfabetização, já que não é suficiente a um sujeito saber ler e escrever, enquanto habilidade de decodificação e codificação. Dominando essas habilidades, o sujeito nem sempre é capaz de fazer uso da escrita e da leitura nas práticas sociais de um mundo letrado e cada vez mais exigente. Nesse sentido, pode-se afirmar que a escola, efetivamente, não forma usuários competentes da escrita, mas, inúmeras vezes, “analfabetos funcionais”, definidos como "aqueles que tiveram acesso limitado à escolarização ou que têm um domínio limitado das habilidades de leitura e escrita”. (RIBEIRO, 2003, p. 10)

É justamente com o objetivo de ampliar o que se entendia por alfabetização que, na década de 90, novas investigações tiveram início no Brasil. O cerne dessas pesquisas era discutir o que se considerava uma outra face da competência leitora e escritora: o letramento. Entre os 
estudiosos que têm marcado as discussões acerca do letramento, vale citar Kato, que, com a publicação de No mundo da escrita: uma abordagem psicolingüística (1987), praticamente introduz a noção de letramento no Brasil. Além dessa autora, Kleiman (1995), Tfouni (1995), Soares (1989 e 1999), Rojo (1998), Ribeiro (2003), apenas para citar outros pesquisadores, ampliam as idéias relacionadas às especificidades do letrar, debatendo o tema em função das práticas escolares mais usuais.

Esses estudos tiveram relevância acentuada subsidiando pesquisas e levantamentos como o INAF (Indicador Nacional de Alfabetismo Funcional), uma iniciativa que, desde 2001, vem investigando periodicamente em uma significativa amostra de brasileiros de 15 a 64 anos (incluindo estudantes de ensino fundamental, médio e superior, pessoas fora da escola e outras que sequer freqüentaram uma instituição escolar), os níveis de alfabetismo e letramento no país. Dentre as conclusões a que podem levar essas pesquisas (Cf. www.ipm.org.br ${ }^{5}$ ), verificou-se que, de fato, boa parte dos sujeitos investigados, embora fossem considerados "alfabetizados” por dominarem tarefas básicas de decodificação e codificação, não atuavam de modo autônomo e competente em práticas sociais de uso da escrita e principalmente da leitura.

Nesse sentido, para essas novas pesquisas, era importante valorizar duas faces do processo de aprendizagem da escrita, uma distinção apresentada com clareza por Soares (1999, p. $57):$

\begin{abstract}
Apropriar-se do sistema de escrita é uma das faces do aprender a escrever; outra face é o desenvolvimento das habilidades de produção do texto escrito. [...] a distinção que é feita [...] entre essas duas faces visa apenas tornar mais clara e mais didática a exposição, já que, nas perspectivas psicogenética e psicolingüística aqui assumidas, essas são faces tão indissociáveis quanto as duas faces de uma mesma moeda: aprender a escrever não é um processo de etapas sucessivas, em que, numa primeira etapa instrumentaliza-se o aprendiz (para que se aproprie do sistema de escrita), e só numa segunda etapa se passa a desenvolver o uso efetivo da escrita. (grifos da autora).
\end{abstract}

Dois são os termos eleitos e empregados por Soares (2003, p. 91) para denominar essas duas faces: “alfabetizar” e “letrar”. Em suas palavras, o uso do termo “alfabetização” aplica-se ao

\footnotetext{
${ }^{5} \mathrm{O}$ acesso a esse site permite links com os Indicadores que nos anos de 2001, 2003 e 2005 tiveram as habilidades de leitura e escrita como foco de investigação.
} 
processo de aquisição da 'tecnologia da escrita, isto é, do conjunto de técnicas procedimentos, habilidades - necessárias para a prática da leitura e da escrita: as habilidades de codificação de fonemas em grafemas e de decodificação de grafemas em fonemas, isto é, o domínio do sistema de escrita (alfabético, ortográfico); as habilidades motoras de manipulação de instrumentos e equipamentos [...], isto é, a aquisição de modos de escrever e de modos de ler [...]. Em síntese: alfabetização é o processo pelo qual se adquire o domínio de um código e das habilidades de utilizá-lo para ler e escrever, ou seja o domínio da tecnologia - do conjunto de técnicas - para exercer a arte e ciência da escrita. (grifos da autora)

O termo “letramento", por sua vez, refere-se

ao exercício efetivo e competente da tecnologia da escrita [...] que implica habilidades várias, tais como: capacidade de ler e escrever para atingir diferentes objetivos [...]; habilidades de interpretar e produzir diferentes tipos e gêneros de textos; habilidades de orientar-se pelos protocolos de leitura que marcam o texto ou de lançar mão desses protocolos ao escrever; atitudes de inserção efetiva no mundo da escrita [...]. (Ibidem, p. 91-92)

“Letrar” tem, nessa concepção, uma amplitude maior do que a ação de “alfabetizar” e, segundo Leite (2001, p. 32),

a tendência atual dos autores é situar a alfabetização como parte desse processo geral de letramento, mas caracterizada pelo domínio da tecnologia da escrita, ou seja, o período em que o aluno aprende os mecanismos da leitura e da escrita e os elementos textuais necessários para construir significados a partir dos textos.

Ao realizar uma análise do significado dessas noções nas práticas escolares, Leite (Ibidem, p. 32) afirma ainda que

O desafio, portanto, que se coloca para os professores alfabetizadores, [...], é como desenvolver o processo de alfabetização numa perspectiva de letramento, isto é, como alfabetizar letrando. Do que já foi exposto até aqui, podemos afirmar que é possível desenvolver o processo de alfabetização escolar simultaneamente ao envolvimento dos alunos com as práticas sociais da escrita.

Em síntese, o que propõem os investigadores que se dedicam a estudos sobre letramento é uma distinção entre essas duas “faces” do ensino da escrita (SOARES, 1999): a apropriação do código alfabético e de suas normas (aspectos notacionais) e a apropriação das habilidades de produção de um texto (aspectos discursivos). Tal diferenciação se faz importante no contexto 
histórico apresentado até aqui pela necessidade efetiva de se ampliar o olhar e as intervenções do professor em prol da formação de um competente escritor, algo que realmente está muito além de um domínio sobre a escrita alfabética.

Nas práticas escolares, porém, novamente essas contribuições têm recebido uma interpretação distorcida. Distinguir as aprendizagens envolvidas no processo de produção e interpretação de textos (letramento) das aprendizagens sobre os princípios que regem nossa escrita (alfabetização), acabou dando origem a intervenções e propostas diferenciadas a fim de evidenciar uma ou outra face da escrita, como se as demandas do ato de escrever pudessem ser, desse modo, dissociadas.

De fato, verifica-se que os vícios nas tentativas de total controle do processo de aprendizagem ou de omissão de intervenções docentes, que se efetivaram na tentativa de transposição didática pós-psicogênese, já comentada, também se repetem aqui. Nesse novo contexto, visando contemplar agora a necessidade de letrar e alfabetizar, a escola oscila, muitas vezes, entre a apresentação de propostas de produção de textos desvinculadas de qualquer situação comunicativa real e outras em que o aluno escreve "espontaneamente”, sem sequer contar com modelos e referências para compor seu texto nem mesmo as intervenções do professor.

Na prática, como se sabe, não é possível separar a escrita de seu contexto de uso. Cabe a qualquer escritor tomar decisões sobre o que está produzindo: simultaneamente constrói e reconstrói seu texto grafando as palavras, levando em conta o princípio alfabético e as normas ortográficas e ainda realizando substituições, incorporando novas idéias, escolhendo a linguagem mais adequada, reorganizando parágrafos etc. Tudo isso a depender do tipo de mensagem que deseja transmitir e do tipo de estrutura eleita com essa finalidade. Nem enquanto prática social nem enquanto inserida nas situações escolares, a escrita supõe reflexões isoladas, ora sobre o princípio alfabético, ora sobre a função e composição de um determinado texto. Por essa razão, nenhum professor tem o poder de controlar as reflexões de seu aprendiz enquanto autor ou leitor de um material escrito. Mesmo se tratando de um aprendiz que ainda não domina o princípio alfabético, não se pode querer que construa mundos paralelos acerca da escrita: o mundo do funcionamento do sistema de escrita e o mundo das práticas e dos textos que circulam socialmente. 
Ainda que fundamentais para se estipular como meta a formação ampla de leitores e escritores na escola, parece que as pesquisas ligadas ao letramento nem sempre têm contribuído para que se conceba a língua escrita como um todo. Tarefa difícil tem sido para a escola entender as produções de textos necessariamente como “propostas de compreensão” (GERALDI, 1997) que se fazem para destinatários e com funções, conteúdos e objetivos muito precisos. Propostas baseadas no sistema de representação como um objeto literalmente indissociável das práticas sociais em que é utilizado e que tenham o sujeito-autor em interação direta com o mundo da escrita, tomando decisões acerca de quais letras utilizar ou de qual a melhor maneira de se dizer o que se deseja, recursivamente.

Nos últimos anos, no entanto, o caminho trilhado por boa parte das escolas brasileiras parece distante de uma abordagem da língua pautada em seu caráter indissociável e de um trabalho sistemático evidenciando as práticas sociais de escrita e fala. Essa distância vem instaurando um quadro caótico no ensino da língua, resultado da dificuldade em se realizar um processo necessário, sério e gradativo de transposição didática e de reconstrução das práticas escolares. Ainda que os Parâmetros Curriculares Nacionais tenham sido publicados há quase uma década, tendo por base os princípios construtivistas, o que se observa, de modo geral, são ações isoladas para a constituição desse fazer pedagógico. Esses paradigmas ainda precisam ser compreendidos e incorporados ao ensino, o que só se tornará viável por intermédio de um amplo e aprofundado programa de formação e capacitação dos professores e de uma necessária articulação do trabalho docente, tarefas árduas e ainda problemáticas se consideradas em âmbito nacional.

Como conseqüência desse quadro, a formação efetiva de leitores e escritores parece longe de se transformar em uma meta alcançável e o processo lento e até desanimador de mudanças gera um espaço de permeabilidade para propostas pautadas em outros referenciais, opostos aos princípios construtivistas e baseadas em técnicas de ensino, que supostamente permitem o controle, passo a passo, das aprendizagens e suprimem a necessidade de reconstrução da prática pedagógica.

A despeito das pesquisas psicogenéticas, das evidências e argumentos em prol da natureza cognitiva do processo de apropriação da escrita e do próprio objeto de conhecimento que é a escrita, debates similares aos da década de 70 (focados apenas no melhor método) têm crescido, especialmente nos meios acadêmicos da Psicologia e sob forte influência da mídia. O 
método fônico vem ressurgindo como caminho possível para o ensino da escrita, contrariando toda uma concepção de sujeito aprendiz ativo, que constrói seu próprio conhecimento, e do que a escrita é enquanto objeto de conhecimento. Essa discussão metodológica vem ganhando novas instâncias, em escolas de educação infantil e do primeiro ciclo do ensino fundamental e ainda em eventos e cursos de formação de professores. Já conquista também espaço em algumas redes municipais, na tentativa de alfabetizar a todos por meio dos mesmos passos.

Segundo Belintante (2005, p. 63 e 65),

os dados obtidos nas avaliações nacionais brasileiras vêm sendo usados como fortes argumentos contra as influências do construtivismo nos documentos oficias e nas redes públicas [...]

Se na década de 80 os dados ruins oriundos das avaliações eram usados para desqualificar os 'métodos tradicionais' e guindar o construtivismo a um topo discursivo, hoje, o que temos é o contrário disso [...].

É fundamental para a presente pesquisa traçar algumas considerações referentes a esse método e principalmente à crítica acirrada que seus defensores fazem à psicogênese e à abordagem construtivista de ensino e aprendizagem, responsabilizando-os pelos problemas no campo da alfabetização. Julga-se que apresentando, em linhas gerais, os pressupostos que embasam o método fônico, a concepção de escrita que se toma e os passos que se estabelece para o ensino, seja possível reforçar a importância das investigações, básicas e didáticas, que defendam o caráter construtivo inerente à apropriação da língua.

\subsection{O MÉTODO FÔNICO: RETOMADA E TENTATIVA DE SOLUCIONAR OS PROBLEMAS DA ALFABETIZAÇÃO NO BRASIL}

Em oposição à proposta construtivista para o ensino da escrita, alguns psicólogos e autores de materiais didáticos têm defendido a implantação nacional do método fônico como alternativa para a alfabetização. Alessandra Capovilla e Fernando Capovilla, líderes no movimento de defesa dessa proposta metodológica, apóiam-se na Psicologia para priorizar no ensino a dimensão técnica da escrita. Tais pesquisadores entendem que

a habilidade de discriminar e manipular os segmentos da fala é um quesito fundamental para a aquisição da leitura e escrita [...]. Seguindo as diretrizes curriculares dos países desenvolvidos, as atividades propostas pelo presente 
programa de alfabetização destinam-se a promover o desenvolvimento da consciência fonológica (CAPOVILLA; CAPOVILLA, 2002, p. 89).

Instituem ainda os passos a ser seguidos para a aprendizagem, organizados a partir de bases científicas estruturadas em estudos realizados em países como Estados Unidos e Dinamarca:

Após as vogais, são introduzidas consoantes prolongáveis, isto é, as consoantes cujos sons podem ser facilmente pronunciados de forma isolada, sem uma vogal. Primeiramente são apresentadas as consoantes regulares (que tendem a possuir apenas um som), Como F, J, M, N, V e Z. Depois, são apresentadas as consoantes facilmente pronunciadas de forma isolada e que são irregulares (ou seja, que tendem a possuir mais de um som), como $\mathbf{L}, \mathbf{S}, \mathbf{R}$ e $\mathbf{X}$. Neste caso, apenas os sons regulares e mais freqüentes dessas letras são apresentados. Os sons irregulares são introduzidos posteriormente, em outras atividades.

Após as consoantes facilmente pronunciáveis são introduzidas as mais difíceis de pronunciar de forma isolada. Neste grupo, estão incluídas as consoantes $\mathbf{B}, \mathbf{C}$, P, D, T, G e Q (CAPOVILLA; CAPOVILLA, 2002, p. 89, grifos dos autores).

Seguindo essa linha, apresenta-se a consoante $\mathrm{H}$ e as letras $\mathrm{K}, \mathrm{W}$ e $\mathrm{Y}$ como não integrantes do nosso alfabeto. Só ao final, serão ensinadas as correspondências grafofonêmicas irregulares, em que se incluem os dígrafos, cedilha, encontros consonantais e os sons irregulares de C, G, R, S, L, M e X. Reitera-se a necessidade de que as crianças aprendam também a seqüência alfabética pelo valor social que possui, facilitando, por exemplo, a consulta a livros, dicionários etc.

Os defensores dessa proposta reconhecem a produção textual como objetivo final da etapa de alfabetização, mas afirmam que

não é possível, porém, chegar efetivamente a tais habilidades sem o prévio desenvolvimento da consciência fonológica e sem o conhecimento das correspondências entre as letras e os sons. Por isso, as atividades de interpretação e de produção de textos são iniciadas [...] apenas após as crianças já terem adquirido algumas habilidades essenciais nos níveis da letra e da palavra. (Ibidem, p. 89)

Os passos a ser trilhados pelo professor e pelos alunos estão explícitos na descrição do método, determinando em uma seqüência ordenada - com base no critério do adulto alfabetizado -, sem considerar os saberes infantis, e em uma perspectiva aditiva (a somatória de informações, das mais simples para as mais complexas, comporá o todo que é a escrita) - o que será foco da 
atenção de todas as crianças a cada instante. Ignora-se o que as teorias já comprovaram, a saber: $1^{\circ}$ ) a aprendizagem da escrita não se dá por uma intervenção puramente externa, metodológica e sistemática, tampouco é fruto direto e necessário do ensino; $2^{\circ}$ ) apropriar-se da escrita supõe um processo de interação e reflexão com e sobre esse objeto; $3^{\circ}$ ) esse processo de apropriação certamente teve início nos primeiros contatos das crianças com o universo letrado, muitas vezes bem antes de seu ingresso na escola, quando já tiveram a oportunidade de, ao menos, andar nas ruas, o que, de fato, basta para que tenham visto textos escritos, letras, números e outros símbolos utilizados em nossos sistemas de representação; $4^{\circ}$ ) o seu próprio nome, comum e importante objeto de interesse e até de análise por parte dos pequenos aprendizes, pode apresentar letras e combinações sonoras ou gráficas consideradas complexas demais pelos defensores do método fônico. Porém, chamar-se Thomas, Shirley ou Mariana pode suscitar nas crianças apuradas e possíveis reflexões, muito mais favoráveis e significativas do que lidar com palavras isoladas ou mesmo inventadas, inexistentes em sua própria língua, aspecto defendido na proposta fônica.

Além dessas ressalvas, outros pontos questionáveis de tal método merecem ser considerados aqui.

O primeiro deles é a própria concepção de escrita tomada, novamente, como um código. Esse objeto está longe realmente de ser um código que estabelece relações unívocas entre os sons e suas representações. A escrita não é uma mera e simples transcrição da fala. Há características peculiares e diferenciadas entre essas duas possibilidades de comunicação.

Não é propósito deste capítulo enveredar pelo campo da Lingüística, área que contempla estudos sobre a consciência fonológica. Entretanto, apenas para citar alguns exemplos dessa distinção, vale apontar, primeiramente, que a fala é uma produção contínua enquanto a escrita é descontínua, marcada por segmentações entre as palavras; além delas, outras segmentações precisam ser descobertas pela criança ao lidar com textos escritos, pois o que falamos pode ser analisado tendo por base diferentes critérios (algo que não fica tão claro somente nas enunciações orais), tais como sílabas e letras. Como se isso não bastasse, a natureza da escrita torna ainda mais insustentável o pressuposto da correspondência letra-som. Importa lembrar que

nem todas as letras correspondem a fonemas, segundo a definição de lingüistas, e muito menos a unidades analisáveis na emissão [...] (só as vogais e alguns fonemas consonânticos são analisáveis ao nível da emissão: podemos prolongar sons como /s/ ou /f), mas não podemos nem prolongar, nem pronunciar isoladamente um som como /p/, /k/) [...] (FERREIRO, 2004, s.p.). 
Em síntese:

¿ Qué conserva la escritura dentro del conjunto de lo que escuchamos "cuando la gente abla”? Sin duda, no todos los fenómenos sonoros que están presentes cuando alguien toma la palabra (BENVENISTE, C.B., 2002, p. 16, grifos da autora). ${ }^{6}$

Um segundo aspecto a ser considerado na proposição do método fônico diz respeito ao foco na leitura de palavras ou "pseudo-palavras", termo que atribuem ao conjunto de vocábulos inventados e apresentados para as crianças, com fins especificamente didáticos. Pautar o trabalho apenas na leitura de palavras e deixar os textos, e a própria produção escrita, para mais adiante, significa ensinar a escrever sem que se considere a escrita em seu contexto, sem que as crianças a tenham, desde sempre, como um instrumento de comunicação.

Em terceiro lugar, a idéia de palavra que se quer ensinar é algo a ser construído conceitualmente pelas crianças e não é passível de transmissão. A noção de palavra de uma criança de 4 ou 5 anos está atrelada a significados precisos e eventualmente distantes da concepção de adultos usuários do nosso sistema de escrita.

O nome próprio é uma das primeiras palavras com significado para as crianças e, qualquer que seja sua composição fonética, será objeto de reflexões por parte desses aprendizes. Ensinar uma análise hierárquica de fonemas simples para os mais complexos, como propõem os defensores desse método, significa ignorar e impedir a ampliação de análises de palavras que as crianças fazem desde sempre, quando seus nomes, os de familiares ou de colegas são compostos por dígrafos, letras não utilizadas em vocábulos da Língua Portuguesa ou fonemas nasais, por exemplo. Essa constatação conduz ao quarto argumento crítico que merece ser destacado. A intenção de criar uma trajetória pré-determinada de aprendizagem, evoluindo do mais fácil para o mais difícil cai por terra em função das experiências e motivações das crianças. O significado e o desejo de aprender o próprio nome podem, entre outros aspectos, favorecer o conhecimento da letra Y, por exemplo, ou a reflexão sobre a complexa relação entre letras e sons se o aprendiz se chamar Thamy ou Raphael. Assim, vale perguntar: o que é fácil ou difícil para as crianças? Quando se pensa na aprendizagem da escrita como um todo complexo, por que subestimar o

\footnotetext{
6 “O que conserva a escrita dentro do conjunto do que escutamos 'quando a gente fala'? Sem dúvida, nem todos os fenômenos sonoros que estão presentes quando alguém toma a palavra.” (Tradução livre - Andréa Luize)
} 
potencial infantil de compreensão? Por que impor aos alunos uma lógica adulta, estranha a seus saberes e interesses?

Em quinto lugar, outra crítica que pode ser feita à proposta fônica diz respeito a idéia de aprendizagem da consciência fonológica. Entendem seus defensores que as relações inerentes a essa aprendizagem podem ser transmitidas pelo professor. A construção da consciência fonológica, de fato, não caminha na contramão do processo de apropriação da escrita. Em pesquisa já publicada, Ferreiro e Vernon (1999) comprovaram que:

- o desenvolvimento da consciência fonológica está estreitamente atrelado ao desenvolvimento da própria escrita. Quanto mais próximas à escrita alfabética, maiores são as possibilidades das crianças de realizar segmentações de palavras em fonemas;

- a aquisição da habilidade de segmentação oral de palavras em fonemas não se dá de maneira aditiva, em que respostas mais avançadas substituem as mais simples, mas também em estágios inter-relacionados de desenvolvimento;

- orientações precisas dadas por um adulto não permitem que todas as crianças “imitem” as segmentações em fonemas. Trata-se de um processo gradativo de apropriação e não pautado em informações apenas.

Assim, à medida que avançam no longo do processo de compreensão dos princípios reguladores de nossa escrita, as crianças realizam análises mais aprofundadas, de caráter intrasilábico, refletindo e aprendendo também sobre as relações entre fonemas e grafemas.

A ação pedagógica precisa centrar-se na possibilidade de favorecer e ampliar essas múltiplas relações. Não se trata de um processo linear, com passos precisos que devem ser dados pelos aprendizes, com análises separadas e hierarquizadas do oral e do escrito;

não há uma relação direta entre uma análise da emissão sonora que precederia a escrita mas uma relação de ida e volta, para a qual o termo 'dialética' é o que melhor convém. (FERREIRO, 2004, s.p.)

Em sexto lugar, não se trata também de trazer para a sala de aula um método que priorize análises fonológicas em detrimento de outros importantes aspectos da língua, entre os quais os semânticos e morfológicos. Quando se considera a língua enquanto objeto histórico e em constante transformação, não se pode deixar de lado as mudanças que sofre seu sistema de 
representação; ignorar esse fato e legar importância apenas ao caráter fonológico do sistema alfabético resulta em um reducionismo do que é a língua escrita. (FERREIRO; VERNON, 1999)

Em função dessa nefasta e inadequada dissociação entre a escrita escolar e a escrita como construção lingüística e instrumento de comunicação, o sétimo ponto da crítica que ora se faz é o descaso da proposta fônica ao processo cognitivo vivido pelo aluno, uma concepção autoritária de aprendizagem que se aplica pela imposição de conteúdos externos.

O material elaborado por defensores de tal método contém ainda acirradas críticas à concepção psicogenética. De maneira geral, a posição tomada por Capovilla e Capovilla parte de equívocos conceituais ao analisar as contribuições de Jean Piaget e Emilia Ferreiro à forma como o sujeito constrói conhecimentos. Ao tematizar o pressuposto que destaca o sujeito aprendiz como ativo no seu processo de construção de conhecimentos, esses psicólogos entendem, de modo equivocado, que pensar e construir hipóteses significa dominar um conhecimento e afirmam que somente a criança que “já sabe” poderá avançar conceitualmente. Ter hipóteses sobre o funcionamento da escrita e explicitá-las não significa ter se apropriado desse objeto em sua totalidade. Um dos princípios do referencial construtivista é justamente considerar as hipóteses e idéias infantis e intervir a partir delas, de maneira que possam avançar conceitualmente; refletir sobre um objeto de conhecimento não pressupõe o completo domínio sobre ele. Isso porque em uma ótica psicogenética, a criança não é alheia ao universo letrado que a rodeia e, mesmo antes de ingressar em uma instituição formal de ensino, mostra-se capaz de observar, pensar e aprender sobre a escrita.

Nesse sentido, na proposta desses mesmos psicólogos, atribui-se apenas à escola o papel de ensinar a ler e escrever e coloca-se a criança como um ser passivo, à espera dessa aprendizagem. Ao registrar como conclusão acerca dos postulados psicogenéticos que “é pouco proveitoso tentar transmitir um mesmo conteúdo a crianças com diferentes conhecimentos prévios”, e ao referir-se ao que chamam de “espera pedagógica” (CAPOVILLA; CAPOVILLA, 2002, p. 37), os defensores da proposta fônica deixam de atentar para os diferentes graus de aproximação que os aprendizes podem chegar e parecem tomar o "ensinar" como um ato fechado, linear e de via única: o professor ensina, as crianças aprendem.

De modo contrário, a abordagem construtivista, pautada, dentre outros, nos postulados das investigações atreladas à Psicogênese, como já se explicitou anteriormente, confere extrema importância às hipóteses e idéias que as crianças podem construir a partir de um objeto de 
conhecimento e considera que o ensino favorecerá aproximações sucessivas em relação às convenções e conceitualizações necessárias à compreensão efetiva desse objeto. Não se trata, entretanto, de um ensino fechado e de via única, mas de uma relação plural e dialógica com o conhecimento; nenhum aprendiz é passivo ao aprender, assim como o professor não é um transmissor de saberes tampouco o único informante em sala de aula.

Como destaca Belintante (2005, p. 67),

\begin{abstract}
Não dá para ser leviano - como alguns intelectuais brasileiros o foram - e imputar a uma pesquisadora séria como Emilia Ferreiro as culpas pelos desarranjos estruturais da educação brasileira. Se há um percentual alto de crianças que ainda não sabem ler, mesmo após quatro anos de escolarização, com certeza isso não se deve às influências do construtivismo ou das idéias de Ferreiro, que muito provavelmente não chegaram a ser assumidas de maneira sistemática no cotidiano das escolas públicas [...].
\end{abstract}

As tentativas de se reverter os problemas da escola no que concerne ao ensino da leitura e da escrita não podem acarretar retomadas de métodos fechados nem desconsiderar por completo o aluno como um sujeito pensante, sobretudo tendo em vista os conhecimentos que ele já construiu.

As pesquisas sobre letramento possibilitaram, de fato, que a produção de textos ocupasse um lugar especial nas preocupações dos professores e no trabalho junto às crianças. Porém, ensinar a ler e escrever convencionalmente, ajudar as crianças a compreender o princípio alfabético e outras normas que regem nossa escrita é algo que a escola, muitas vezes, não sabe fazer em uma perspectiva construtivista. Daí o espaço que encontram os defensores do método fônico em suas tentativas de convencer políticos e educadores, e até o público em geral por meio da mídia, do caráter salvacionista dessa “nova” (ou arcaica e ultrapassada?) proposta.

Mais de vinte e cinco anos se passaram desde a publicação da "Psicogênese da Língua Escrita”, (FERREIRO; TEBEROSKY, 1999), mas ainda imperam as dificuldades em se compreender a escrita como um objeto a ser construído pelo aprendiz, de modo gradativo, a partir do estabelecimento das mais diferenciadas relações e usando os textos em suas funções sociais.

É preciso que se entenda a escrita à luz das tantas pesquisas aqui citadas e de outras, já divulgadas ou em curso, que consideram os princípios básicos do referencial construtivista. Igualmente faz-se necessário compreender a escrita levando em conta sua funcionalidade e suas características enquanto um sistema de comunicação social. O debate sobre a prática pedagógica 
só poderá caminhar rumo a boas soluções se a escrita for reconcebida pelos professores e pelos demais sujeitos atuantes no universo escolar. Além disso, deve-se compreender a função da escola na formação de um usuário competente da língua. O que isso significa, de fato?

Com a missão de resgatar o escrever em seu caráter social e de aprimorar o que se entende como papel da escola, importa considerar a escrita em sua dimensão representativa no contexto da cultura letrada.

\subsection{CULTURA LETRADA, CULTURA ESCRITA E A ESCRITA COMO UM SISTEMA DE REPRESENTAÇÃO}

Para que a escrita se torne um objeto de ensino e aprendizagem, é preciso, antes de tudo, ter-se clareza do que ela representa enquanto objeto de conhecimento. Pode-se afirmar que a escrita assume as mais diferentes facetas na escola a depender de como ela é concebida social e historicamente.

A escrita é hoje - social, histórica e cientificamente - um rico instrumento de comunicação; as diferentes formas de discurso permitem que mensagens das mais diversas naturezas (uma informação pesquisada, um recado, uma série de instruções etc) sejam transmitidas e interpretadas em um processo vivo, um processo de interação entre sujeitos (produtores e leitores) por meio dos textos que elaboram.

Se a língua escrita assim é concebida fora da escola, se assim se constitui como objeto sócio-cultural e científico, também assim deve ser entendida como objeto que se ensina. À escola cabe entender e trabalhar com a escrita sem desconfigurá-la e sem tê-la como imutável. É preciso que os educadores compreendam a escrita e seu papel no mundo de hoje e sejam efetivamente capazes de ampliar a inserção dos alunos em sua cultura letrada, objetivo maior do trabalho com a língua na escola. O termo "ampliar” aparece como especialmente legítimo porque, de modo indiscutível, as crianças já ingressam nos primeiros anos de escolaridade com vivências em relação à escrita, à leitura, à fala e à escuta em sua Língua. Falar, ouvir, escrever e ler são competências a ser construídas pelo sujeito a fim de que se aproprie das mais diferentes práticas, das mais diferentes sociais situações de uso, formais ou informais. Inserir-se na cultura letrada também implica conhecer e fazer uso dos diferentes recursos disponíveis para a comunicação, inclusive os da era digital: o processador de textos, a Internet, os correios eletrônicos etc. 
A expressão “cultura letrada” será defendida e utilizada na presente pesquisa, conforme proposta por Emilia Ferreiro, e entendida também como meta principal da escola na formação dos sujeitos, no que diz respeito à sua Língua: “O que devemos dizer é ‘cultura letrada’, para nos aproximarmos do significado original de literacy" (FERREIRO, 2002, p. 55), enquanto competência do sujeito para acessar os conhecimentos construídos socialmente, pela leitura ou pela escuta, e, ainda, atuar sobre tais conhecimentos, reelaborando-os ou construindo novas e diferentes enunciações, via escrita e via fala. Mais especificamente, ao referir-se às competências leitoras e escritoras, a pesquisadora faz uso do termo "cultura escrita”, assim intitulando uma de suas últimas publicações traduzida para o português: "Cultura escrita e educação”.

Cabe aqui retomar as discussões relativas ao letramento, com o objetivo de defender tal noção como insuficiente para que se conceba a língua de forma integral. Em primeira instância, letrar e alfabetizar são termos e ações que, mesmo em conjunto, não nos remetem ao todo que representa conhecer e fazer uso de nossa língua. Quando se foca a atenção no letrar e no alfabetizar, de acordo com definições já citadas, deixa-se a escrita e a leitura no centro do processo em prejuízo de outras competências relativas à fala e à escuta, igualmente significativas para a atuação social do sujeito, visto também serem meios de comunicação.

Por outro lado e, em segunda instância, as concepções inerentes ao letrar e ao alfabetizar tiram da escrita o que ela tem de mais singular e o que mais merece ser considerado nas situações escolares: seu caráter de sistema de representação, de objeto não passível de qualquer dissociação. Colocar a escrita no status de um código significa estabelecer o que ela não é. Um código é um conjunto formado por símbolos que se referem, “de maneira unívoca (um para um), a um conjunto de objetos (exemplos: código Morse, código de barras, Braile)” (FERREIRO, 2005, s.p.). Códigos costumam ser invenções racionais e individuais, tanto que tendem a receber o nome de seus criadores. A escrita está longe de se configurar dessa maneira justamente por ser uma produção cultural, histórica e social e também por não possuir apenas relações unívocas. A necessidade de convenções ortográficas ilustra essa questão: não há um símbolo único para cada objeto. Ainda há em jogo seu caráter mutável: a escrita se transforma nas mãos de seus usuários e em função dos usos que dela se quer fazer. E é assim que também será apropriada, internalizada pelos escritores-aprendizes. Afinal, "quando o que é originalmente um instrumento de comunicação se torna um objeto sobre o qual se pensa [...] a própria linguagem se transforma” (FERREIRO, 2001a, p. 76). As mensagens eletrônicas são bons exemplos. Há algum tempo, 
poucos compreenderiam o significado da palavra "vc" no meio de um texto ou mesmo de "bj". Em mensagens eletrônicas, essas novas maneiras de representar os termos "você" e "beijo" são comuns e facilmente interpretadas.

Tais restrições ao uso dos termos "letrar" e "alfabetizar" - porque não abarcam a totalidade do que é ser um usuário da língua e porque tomam o sistema de escrita como um código - desestimulam a construção de práticas escolares, de opções didáticas voltadas à inserção na cultura escrita e igualmente na cultura letrada, meta maior na formação do usuário de uma língua.

É bem verdade que o nosso sistema de representação tem como uma de suas principais características a "alfabeticidade".7 Trata-se também de um sistema ortográfico. Mas o funcionamento desse sistema não justifica a dissociação pedagógica entre o aprender o usar a escrita. Quando ela é vista em sua totalidade, temos, desse modo, o conhecimento sobre as normas que regem e organizam esse sistema e as diferentes formas de comunicação que, com ele, podem ser estabelecidas: os textos.

Se tida como crucial para as interlocuções escritas e se, desde sempre, entendemos também "a produção de textos [...] como ponto de partida (e ponto de chegada) de todo o processo de ensino/aprendizagem” (GERALDI, 1997, p. 135) desse objeto - tanto quanto da leitura -, o princípio alfabético deixa de ser um código e passa a se configurar realmente como um sistema de representação. Produzindo e lendo textos com propósitos claros e destinatários precisos, ainda que em desacordo com as convenções desse sistema, as crianças estarão sendo convidadas a resolver problemas que a necessidade de se comunicar lhes impõem e a refletir sobre a escrita em sua totalidade.

Rompendo definitivamente com a divisão entre o 'momento de aprender' e o 'momento de fazer uso da aprendizagem', os estudos lingüísticos propõem a articulação dinâmica e reversível ${ }^{8}$ entre 'descobrir a escrita (conhecimento de suas funções e formas de manifestação), 'aprender a escrita’ (compreensão das

\footnotetext{
${ }^{7}$ Toma-se aqui por empréstimo o termo “alfabeticidade”, citado em Trecho do Documento de Atualização Curricular no 2 - Língua - Educação Geral Básica $1^{\circ}$ ciclo - Secretaria de Educação/ Direção de Currículo - Buenos Aires 1996.

A utilização desse termo tem por meta destacar que o princípio alfabético é apenas "uma” das características de nosso sistema de representação. A expressão usual "sistema alfabético" tende a restringir o sistema a essa única característica.

${ }^{8}$ Nota de Colello: "Dinâmica porque pressupõe o movimento intenso de um pólo ao outro; reversível porque a experiência em qualquer um dos pólos remete ao amadurecimento nos demais.” (COLELLO, 2004, p. 113)
} 
regras e modos de funcionamento) e 'usar a escrita' (cultivo de suas práticas a partir de um referencial culturalmente significativo para o sujeito) (COLELLO, 2004, p. 113, grifos da autora).

A continuidade de pesquisas que possam enriquecer os conhecimentos sobre a aprendizagem da escrita, em sua dimensão construtiva, inclusive da aprendizagem de seu sistema de representação, o suposto “código”, se faz necessária e fundamental não apenas visando a contribuir para a prática pedagógica, mas também para reiterar a importância das contribuições advindas dos estudos psicogenéticos (entre os quais os de Piaget e Ferreiro) e sociointeracionistas (conforme são usualmente classificados os estudos de Vygotsky e Bakhtin), nesse momento preocupante em que se questiona as diretrizes nacionais do ensino da língua. Inserida nesses propósitos, a investigação que ora se busca apresentar será detalhada a partir do capítulo a seguir. 


\section{A PESQUISA}

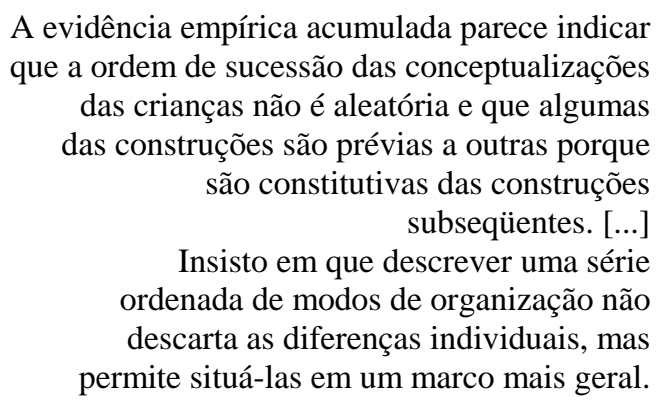

(FERREIRO, 2003, p. 86)

A partir das considerações teóricas no capítulo inicial desta dissertação, será apresentada a organização da pesquisa de campo, realizada nos meses de abril e maio de 2005. O objetivo deste capítulo é caracterizar as situações de produção textual propostas aos sujeitos bem como as hipóteses, objetivos e metodologia que as nortearam. Ademais, sua justificativa teórica e também o caráter didático das situações de pesquisa serão explicitados.

Antes, porém, da apresentação da estrutura da coleta de dados, faz-se necessário retomar alguns pressupostos cruciais para a compreensão deste trabalho investigativo e introduzir alguns novos, igualmente relevantes.

\subsection{PRESSUPOSTOS TEÓRICO-METODOLÓGICOS}

Considerando a concepção de escrita em um referencial construtivista e a apropriação desse objeto na escola, isto é, o processo de aprendizagem como construção de conhecimentos que amplia a inserção do sujeito em sua cultura letrada, o professor tem como tarefa primordial planejar, organizar e proporcionar diferentes situações interativas entre os aprendizes e esse objeto de conhecimento.

Para que a produção de textos constitua um ensino de conhecimento e produção é preciso que a escola resgate professor e alunos como sujeitos que se debruçam sobre um objeto a conhecer e que compartilha, no discurso da sala de aula, contribuições exploratórias na construção de conhecimento. (FREITAS, 1994, p. 113). 
A pesquisa que aqui será apresentada parte da idéia de que a compreensão da escrita é um processo individual, mas vivido no âmbito social. Tal compreensão transcende a assimilação das regras geradoras do nosso sistema de representação. Nessa perspectiva, é fundamental que as crianças possam participar na escola de situações em que a escrita é utilizada prioritariamente como um instrumento de comunicação, mesmo que não o façam de maneira convencional, ou seja, grafando as palavras de acordo com o princípio alfabético. Somente atuando em situações reais de produção textual, poderão refletir paralelamente sobre a composição da mensagem que desejam escrever e a forma que deve tomar, a depender das características do texto em jogo e dos destinatários escolhidos, e também sobre a maneira como grafar cada uma das palavras, tendo em vista os conhecimentos que possuem sobre a temática e as convenções lingüísticas socialmente estabelecidas. Em outras palavras, é atuando como escritoras que poderão refletir sobre todos os aspectos pertinentes ao ato de escrever quando se tem em mente uma comunicação; é na tentativa de buscar soluções para os eventuais problemas comunicativos, e refletindo sobre esses, que as crianças poderão, efetiva e gradativamente, se apropriar da escrita.

Quando se propicia situações de escrita na escola, configuradas como efetivos desafios de comunicação, e, mais, quando se propõe produções de textos em parceria, possibilitando a interação entre sujeitos autores, instaura-se uma oportunidade rica de intercâmbio. Além da necessidade de buscar um consenso sobre o conteúdo a ser registrado, as crianças vivenciam a experiência de resolver problemas sobre a escrita, sendo dela usuárias, a partir das hipóteses que já construíram, explicitando-as e colocando-as em confronto com o que pensam seus parceiros e com outras escritas presentes no mundo. As idéias que constroem sobre o papel e a função da escrita, sobre como se escreve em nosso sistema e sobre as formas que pode tomar essa escrita com base nos propósitos, no grau de formalidade que se quer imprimir, no tipo de mensagem e seus destinatários -, são fundamentais para que avancem.

Nesse sentido, importa destacar a relevância de duas noções amplamente exploradas por algumas teóricas, entre as quais a piagetiana, e que se aplicam a apropriação de qualquer objeto de conhecimento: erro e conflito cognitivo. Entende-se que, a partir das hipóteses que elaboram, os aprendizes precisam ter a oportunidade de cometer "erros, explicitá-los, refletir sobre eles, checá-los com as idéias dos colegas e com as próprias convenções científicas, históricas e sociais. Conflitos cognitivos precisam ser vividos para que estabeleçam importantes relações entre os procedimentos que dominam, as idéias e informações que possuem e os novos conhecimentos. 
Tais noções merecem especial destaque, visto serem cruciais para a coleta e análise dos dados Podem, inclusive, estimular um olhar diferenciado para a aprendizagem situando seu caráter processual e individual.

O erro construtivo, denominação atribuída nos estudos psicogenéticos, tem um caráter diferente do que se pode apontar somente como uma falha ou um engano. Esses e outros estudos redimensionaram a concepção de erro que se tinha na escola (e que, em algumas instituições educativas, ainda se tem), considerando que, em muitos casos, errar representa um ato inteligente e ativo por parte do aprendiz. Significa dar vazão às tentativas de agir sobre e de compreender o objeto de conhecimento em questão e pode ser a base para o próprio desenvolvimento da inteligência, consolidando-se, possivelmente, como uma fonte para a tomada de consciência (Cf. TAILLE, 1997).

Pode-se afirmar que:

a presença de teorias erradas é preferível à ausência delas, ou seja, preferível à ausência de uma reflexão sobre os fenômenos do mundo. Os recentes estudos sobre a psicogênese da língua escrita mostraram bem o quanto é mais rico uma criança acreditar que as sílabas são representadas por uma letra só, do que não possuir hipótese alguma sobre como se escrevem as palavras (TAILLE, 1997, p. 30).

O erro de natureza construtiva não é algo passível de correção, não se trata, nesse caso, de substituir uma resposta errada por uma certa, como em outras falhas que um sujeito comete já tendo se apropriado, por exemplo, da escrita convencional. O ensino tradicional tende a desconsiderar tal aspecto e a tarefa de corrigir “erros” cabe ao professor, que a realiza sem sequer perceber, muitas vezes, as idéias do aprendiz que os geraram. Taille (Ibidem, p. 30) insiste em dizer que: “Será uma ignorância [...] se o erro for unicamente avaliado em relação ao ‘certo’ e não pensado a partir de sua qualidade intrínseca”.

Escritores que dominam a ortografia e grafam incorretamente uma palavra estão cometendo um engano, um equívoco cuja correção permite o acerto. Mas, quando se trata de um erro construtivo, pautado nas concepções que o aprendiz tem em um dado momento, qualquer correção não necessariamente promoverá compreensão e novas conceitualizações. O erro, nesse caso, é um caminho para o acerto, para a apropriação dos conhecimentos, até mesmo da escrita: 
[...] por trás dessas 'respostas estranhas' apresentadas pela criança em diferentes momentos da evolução, há um esforço cognitivo a ser considerado. Mesmo que 'incorretas' em relação ao padrão convencional de comportamento ou sistema, tais respostas não são aleatórias, nem ignorantes. Muito pelo contrário, elas se configuram como 'erros construtivos', naturais e necessários no processo de construção de conhecimentos. Naturais porque ocorrem com todas as crianças; necessários porque favorecem [...] a evolução do processo em questão. (COLELLO, 2004, p. 35)

Importante enfatizar que o erro construtivo precisa ser reconhecido e considerado no âmbito escolar para se tornar ainda mais relevante para o processo de aprendizagem se o próprio aprendiz tiver a possibilidade de refletir sobre ele. Nas relações de cooperação e interação entre aprendizes, o erro construtivo pode se transformar em um foco de significativas discussões. A necessidade de justificar, de argumentar sobre a grafia de uma palavra - tomando um exemplo que faz referência à escrita enquanto objeto de análise - favorece a tomada de consciência sobre as diferentes hipóteses que os aprendizes podem ter sobre a organização da escrita alfabética.

Na escola, é fundamental que as crianças participem de situações em que possam colocar em jogo esses erros construtivos e confrontá-los. No enfrentamento de posições divergentes, a necessidade de compreender, explicar, discutir e responder ao colega pode resultar em conflitos cognitivos. Vividos em diferentes momentos de seus processos de aprendizagem, eles levam ao desequilíbrio e à reformulação de suas hipóteses.

O conflito cognitivo se constitui na medida em que o sujeito lida com algo que lhe é apenas parcialmente assimilável, mas sobre o qual tem a possibilidade de refletir; ele é levado a rever e modificar suas idéias iniciais, realizando um esforço de assimilação, o que pode facilitar a passagem para uma compreensão mais avançada a partir de uma nova conceitualização. Esse tipo de conflito marca um momento de desequilíbrio cognitivo por parte do sujeito impondo a ele a necessidade de adaptar seus esquemas de conhecimento a um novo objeto, suas características, relações e implicações.

Para favorecer a compreensão desses aspectos, é fundamental recorrer à própria teoria piagetiana, que entre seus postulados, destaca:

Toda ação comporta dois aspectos. Um aspecto 'particular', circunstancial, por assim dizer, que depende das características peculiares da situação; para que a ação do sujeito seja ajustada, deve levar em conta as propriedades particulares do objeto sobre a qual se exerce: deve acomodar-se ao objeto. Mas uma ação jamais é totalmente nova, completamente diferente das outras ações possíveis que o organismo é capaz de exibir em um determinado momento; do ponto de 
vista do conhecimento, o "importante é o que, em cada ação, é transponível ou generalizável, isto é, seu ou seus 'esquemas"” (APOSTEL, MORF; PIAGET apud COLL E GILLIÉRON, 1997, p. $34^{9}$ ).

Desse modo,

[...] toda conduta é uma assimilação do dado a esquemas anteriores [...] e toda conduta é, ao mesmo tempo, acomodação destes esquemas à situação atual. Daí resulta que a teoria do desenvolvimento apela, necessariamente, para a noção de equilíbrio, pois toda conduta tende a assegurar equilíbrio entre os fatores internos e externos ou, mais em geral, entre a assimilação e a acomodação (PIAGET, 1991, p. 95 e 96, grifos do autor).

No caso da escrita, pode-se afirmar que as hipóteses que as crianças possuem são de fato indicadores importantes de que elas atuam ativamente em seus processos de construção de conhecimentos, um processo de assimilação, acomodação e equilibração. Essa atuação construtiva por parte do aprendiz permite que ele, aos poucos, interprete a realidade e lhe atribua significados. Necessariamente isso ocorre em função das experiências que vivenciou e dos seus conhecimentos ou informações, o que torna os processos de aprendizagem únicos. Não se pode afirmar com precisão em que momento um sujeito poderá avançar em suas conceitualizações ou mesmo que tipo de situação promoverá uma nova conquista, novos processos de equilibração. Não se pode planejar com exatidão que, em uma dada proposta de atividade ou em parceria com um determinado colega, um aprendiz vivencie um conflito cognitivo de modo a avançar em sua compreensão sobre a escrita. E é justamente por essa razão que passa a ser papel da escola favorecer várias e diferenciadas situações de interação envolvendo o aprendiz e o objeto do qual busca se apropriar. Vivenciando um conjunto de interações, o sujeito terá a oportunidade de lidar com problemas diversos e se defrontar com a necessidade de buscar soluções para eles.

A partir dos pressupostos apresentados como aportes para a presente pesquisa, pode-se tecer considerações também sobre o papel da escola. É essencial que essa instituição e particularmente seus professores planejem e avaliem situações variadas de interação das crianças com a escrita enquanto objeto de conhecimento. É pela pluralidade de situações interativas com a escrita, inclusive partilhadas com outros aprendizes, que se pode buscar atender às demandas

\footnotetext{
${ }^{9}$ O trecho final da citação, entre aspas, pertence ao texto original: APOSTEL, L.; MAYS, W.; MORF, A. e PIAGET, J. Les liasions analytiques et synthétiques dans les comportements du sujet. Paris: Presses Universitaires de France, 1957, p. 46.
} 
específicas de cada sujeito, o qual, lidando com problemas de naturezas diversas (o tipo de texto que escrevem; os diferentes propósitos e destinatários que guiam a produção textual; o tipo de tarefa que realizam frente à escrita - grafar ou ditar, por exemplo; a atuação autônoma ou em parceria etc), poderá explicitar, confrontar e refletir sobre suas idéias, procedimentos e informações e avançar na compreensão desse complexo objeto de conhecimento.

Dentre essas situações de interação é preciso se destacar também a necessidade de atuação sobre a escrita por intermédio de diferentes “auxiliares externos”, criados culturalmente para facilitar e ampliar a ação humana, como é o caso do computador. Faz-se necessário ainda analisar as possíveis influências e utilizações desse recurso na aprendizagem da escrita.

Com os pressupostos apresentados, esta pesquisa propõe a análise das articulações entre o processo interlocutivo de crianças de 4 a 6 anos na produção escrita e seu resultado, isto é, o próprio texto.

O que se pretende é uma análise de diferentes situações de interação na produção textual, vividas por duplas de crianças, e suas implicações para o contexto de sala de aula. Tratase, portanto, de uma investigação de natureza didática, que aparece mais bem detalhada no tópico que se segue.

\subsection{CARACTERIZAÇÃO DA PESQUISA}

Interessa pouco a essa investigação uma análise quantitativa e comparativa entre os sujeitos-autores, em particular, e suas produções. O foco da análise está em identificar tendências similares nos processos vivenciados pelas duplas de crianças na elaboração de quatro textos propostos, atentando para o tipo de interferência de um na tarefa do outro (já que as crianças atuaram em tarefas fixas de ditante ou escriba), as discussões sobre a organização do texto, seu conteúdo e sobre a grafia das palavras, entre outros aspectos.

A sala de aula é um espaço que precisa ser compreendido como uma constante

[...] situação de mediação, o intercâmbio de informações entre crianças que ainda não escrevem convencionalmente precisa ser não só aceito como estimulado (WEISZ, 1988, p. 45).

A relevância da interação é uma importante premissa desta pesquisa, assim como a natureza singular do processo interlocutivo que cada parceria vivencia, afinal, 
a linguagem [...] só tem consistência enquanto 'real' na singularidade do momento em que se enuncia. A relação com a singularidade é da natureza do processo constitutivo da linguagem e dos sujeitos de discurso. [...] Focalizar a linguagem a partir do processo interlocutivo exige instaurá-lo sobre a singularidade dos sujeitos; as interações [...] se tornam possíveis enquanto acontecimentos singulares. (GERALDI, 1997, p. 5 e 6, grifos do autor)

Entretanto, reconhecido o caráter único das interações e interlocuções vividas pelos aprendizes, interessa buscar nesses processos o que também se instaura como mais freqüente, considerando as reflexões e as hipóteses que elaboram as crianças visando a solucionar os desafios impostos por diferentes propostas de produção textual. Do ponto de vista didático, a identificação de tendências nas respostas e nos percursos trilhados pelas crianças favorecerá uma análise mais apurada de algumas das situações de escrita que podem fazer parte do contexto escolar e de aspectos inerentes a esse objeto de conhecimento, os quais podem ser potencializados por meio delas.

A proposta da pesquisa é analisar o processo de interlocução entre crianças, organizadas em duplas para a produção de textos em condições específicas. Para cada dupla, foram apresentadas quatro situações-problema para que vivenciassem interações diferenciadas com a escrita, a saber:

- Produção de uma parlenda conhecida de memória, no papel;

- Produção de uma parlenda conhecida de memória no computador, utilizando o WORD como processador;

- Produção de uma lista de bagagem para uma viagem, no papel;

- Produção de uma lista de bagagem para uma viagem no computador, utilizando o WORD como processador.

As propostas elencadas acima abrangem as variáveis que aqui se deseja analisar: textos conhecidos de memória e textos cujo conteúdo é preciso decidir; textos escritos tendo o papel como recurso e textos escritos com um processador como recurso, além de textos que supõem a presença de palavras e numerais.

Procurou-se eleger textos similares em cada bloco: as duas parlendas faziam parte do repertório de textos memorizados por todas as crianças observadas e em ambas havia a presença de numerais; as duas listagens tinham um mesmo tema - bagagem para uma viagem -, mas variavam em função da temperatura e da característica dos locais (montanha com clima frio e praia com clima quente). Nas listagens também se incluiu a presença de numerais (quantidade de 
itens, considerando-se uma permanência de três dias nos locais), para que isso não fosse um diferencial em relação às propostas de produção 1 e 2.

No total, foram observadas 16 crianças (com idades entre 4 anos e 10 meses e 6 anos e 9 meses) agrupadas em oito duplas fixas, definidas por critérios usualmente utilizados nas classes em que estudam para a formação de parcerias em atividades de escrita. Cada dupla participou das quatro produções de textos descritas (uma por semana), atuando ao longo do período de oito semanas (entre abril e maio de 2005). No intuito de favorecer a observação detalhada do processo de interlocução, a situação de pesquisa, embora trazendo propostas já familiares às crianças, foi apresentada e desenvolvida longe dos grupos-classe, respectivamente denominados de "Grupo 3" (do qual faziam parte quatro duplas de crianças) e "Grupo 4” (outras quatro duplas), conforme demonstra o quadro que se segue:

\section{QUADRO 1 - APRESENTAÇÃO DAS DUPLAS DE CRIANÇAS}

\begin{tabular}{|c|c|c|c|c|c|}
\hline & $\begin{array}{c}\text { Alunos do } \\
\text { Grupo } 3\end{array}$ & $\begin{array}{c}\text { Idade } \\
\text { (mês de Abril de 2005) }\end{array}$ & & $\begin{array}{c}\text { Alunos do } \\
\text { Grupo } 4\end{array}$ & $\begin{array}{c}\text { Idade } \\
\text { (mês de Abril de 2005) }\end{array}$ \\
\hline $\begin{array}{c}\text { Dupla } \\
1\end{array}$ & $\begin{array}{l}\text { Giulia } \\
\text { Guilherme }\end{array}$ & $\begin{array}{l}5 \text { anos e } 9 \text { meses } \\
5 \text { anos e } 5 \text { meses }\end{array}$ & $\begin{array}{c}\text { Dupla } \\
5\end{array}$ & $\begin{array}{l}\text { Camila } \\
\text { Jhoão }\end{array}$ & $\begin{array}{l}6 \text { anos e } 7 \text { meses } \\
6 \text { anos e } 6 \text { meses }\end{array}$ \\
\hline $\begin{array}{c}\text { Dupla } \\
2\end{array}$ & $\begin{array}{l}\text { Daniel } \\
\text { Flora }\end{array}$ & $\begin{array}{l}5 \text { anos e } 7 \text { meses } \\
4 \text { anos e } 11 \text { meses }\end{array}$ & $\begin{array}{c}\text { Dupla } \\
6\end{array}$ & $\begin{array}{l}\text { Antonio } \\
\text { Brunno }\end{array}$ & $\begin{array}{l}6 \text { anos e } 9 \text { meses } \\
5 \text { anos e } 10 \text { meses }\end{array}$ \\
\hline $\begin{array}{c}\text { Dupla } \\
3\end{array}$ & $\begin{array}{l}\text { Beatriz } \\
\text { Luiz }\end{array}$ & $\begin{array}{l}4 \text { anos e } 10 \text { meses } \\
5 \text { anos e } 5 \text { meses }\end{array}$ & $\begin{array}{c}\text { Dupla } \\
7\end{array}$ & $\begin{array}{l}\text { Angela } \\
\text { Vítor }\end{array}$ & $\begin{array}{l}5 \text { anos e } 10 \text { meses } \\
6 \text { anos e } 3 \text { meses }\end{array}$ \\
\hline $\begin{array}{c}\text { Dupla } \\
4\end{array}$ & $\begin{array}{l}\text { Pedro } \\
\text { João }\end{array}$ & $\begin{array}{l}5 \text { anos e } 4 \text { meses } \\
5 \text { anos e } 4 \text { meses }\end{array}$ & $\begin{array}{c}\text { Dupla } \\
8\end{array}$ & $\begin{array}{l}\text { Pedro H. } \\
\text { Clara }\end{array}$ & $\begin{array}{l}5 \text { anos e } 9 \text { meses } \\
5 \text { anos e } 7 \text { meses }\end{array}$ \\
\hline
\end{tabular}

Todas as crianças estudavam em São Paulo, na Escola da Vila, na mesma unidade e período. Para justificar a opção pela pesquisa nessa instituição, cabe, em primeiro lugar, lembrar que a escola é um dos centros de referência no campo da educação em uma abordagem construtivista. Em segundo lugar, e justamente por conta dessa abordagem, as crianças estão acostumadas a atuar em situações reais de produção de textos, com propósitos e destinatários pré- 
determinados. Ainda que não escrevam de maneira convencional, são usualmente colocadas em situações-problema similares às propostas para investigação.

Da mesma forma e pela mesma razão, dividir a produção de textos com outros colegas não se configura como uma novidade para essas crianças, bem como a utilização do computador como recurso para a produção. A familiaridade com essas variáveis (produção de textos diversos, divisão de tarefas com um colega e uso do computador) era fundamental para a pesquisa que está sendo descrita, a fim de se observar a interlocução entre as crianças que vivenciam rotineiramente experiências semelhantes em sala de aula. Não era favorável, portanto, que as situações nas quais as crianças fossem colocadas ao longo da pesquisa representassem novidades naquele exato momento. Importante era que já tivessem um repertório de procedimentos favoráveis para sua atuação: escrever textos, se predispor, sem resistências, à tarefa de tentar escrever; escrever ditando para um colega, escrever o que um colega dita, ouvir atentamente o colega, consultá-lo, escrever no computador etc.

Algumas das crianças, sobretudo as do Grupo 4, já conheciam vagamente a investigadora e a identificavam como professora da mesma série do período da tarde. Entretanto, assim como as demais, não haviam atuado sob suas orientações em situações de sala de aula.

Para a realização das observações, as crianças atuaram dentro de seu período de aula (matutino).

As consignas dadas para cada uma das situações tiveram o cuidado de contextualizar a atividade de modo a assegurar a razão para a escrita. Nesse sentido, as listas tinham um caráter comunicativo mais amplo, fora do contexto especificamente escolar, enquanto as parlendas seriam retomadas posteriormente junto aos próprios alunos das classes. Eis uma síntese de como foram propostas as atividades:

- Produção de texto 1 - parlenda conhecida no papel: "Vou pedir que vocês escrevam, nesse papel, a parlenda 'Um, dois, feijão com arroz'. Depois, vocês a apresentarão para os colegas da classe. Você irá ditar e você escrever o que dita seu (sua) colega.”

- Produção de texto 2 - parlenda conhecida no computador: “Outra vez, vou pedir que vocês s escrevam, no computador, uma parlenda, 'A galinha do vizinho'. Vocês irão levar a parlenda para mostrar na classe. Você irá ditar e você escrever o que dita seu (sua) colega.” 
- Produção de texto 3 - lista de bagagem para uma viagem a um lugar quente (praia): "Vocês, crianças do Grupo 3/Grupo 4 e as professoras, vão realizar um acampamento. Se esse acampamento durasse 3 dias e fosse em uma praia onde estivesse muito calor, o que nós três (vocês e eu) precisaríamos levar na bagagem? Vou pedir que vocês organizem uma lista do que levar, nesse papel. Você irá ditar e você escrever o que dita seu (sua) colega.”

- Produção de texto 4 - lista de bagagem para uma viagem a um lugar frio (montanha): "Vocês, crianças do Grupo 3/Grupo 4 e as professoras, vão realizar um acampamento. Se esse acampamento durasse 3 dias e fosse em uma montanha onde estivesse muito frio, o que nós três (vocês e eu) precisaríamos levar na bagagem? Vou pedir que vocês organizem uma lista do que levar, no computador. Você irá ditar e você escrever o que dita seu (sua) colega.”

As duplas foram mantidas ao longo das produções e assim também se mantiveram nos papéis que deveriam exercer: uma criança sempre ditando o texto e outra sempre escrevendo o que ditava o colega, fosse no computador ou no papel.

As situações de observação foram acompanhadas exclusivamente pela investigadora, que registrou as discussões entre as crianças via anotações escritas e gravações em cassete na tentativa de poder captar o processo de produção textual em sua amplitude e complexidade: as decisões tomadas, as dúvidas, as hesitações, os debates, as informações solicitadas, as buscas de referência e apoio para a escrita etc.

\subsection{JUSTIFICATIVAS}

Importa, aqui, reiterar que a presente investigação se insere na necessidade de continuidade de pesquisas que tenham por base os postulados construtivistas, bem como estudos mais específicos, como os de caráter psicogenético, contribuindo para as tentativas de se desvendar características e possibilidades das crianças em seus processos de construção de conhecimentos.

Nesse momento de questionamentos a respeito das diretrizes pedagógicas assumidas nacionalmente, em especial no campo do ensino da escrita, também é crucial insistir em reflexões sobre as decisões didáticas. Torna-se de extrema relevância refletir sobre como intervir para 
favorecer a apropriação do sistema de representação da escrita em uma perspectiva que possa contemplar as análises lingüísticas acerca das peculiaridades de organização de tal sistema, seu uso social, a explicitação de hipóteses por parte dos aprendizes e, finalmente, a partir de uma perspectiva que favoreça a redescoberta da escrita pelas crianças, as quais, desde sempre, precisam ser colocadas em situações em que escrever se faça necessário, real e possível.

Deve-se refletir também sobre as interlocuções fundamentais em sala de aula: como se pode aprender a partir da instabilidade criada por quem também não domina a escrita convencional? Como que crianças supostamente tomadas como incompetentes para escrever podem resolver juntas problemas que a escrita lhes traz? E como podem, de forma simultânea, avançar e interferir no processo de construção de conhecimentos de outras crianças?

A partir dessas questões, tomou-se o fato de que a interlocução entre crianças-aprendizes parece particularmente pouco conhecida e insuficientemente explorada em pesquisas. É possível que esse aspecto tenha como justificativa uma tendência maior por parte dos investigadores de focar suas análises no processo individual de construção de conhecimentos, desenvolvimento ou mesmo aproveitamento escolar. Não se pode negar a relevância desses estudos, já que inúmeras regularidades observadas entre os sujeitos analisados e suas respostas favoreceram a construção de generalizações que tanto contribuem para que se compreenda a natureza da aprendizagem. Porém, igualmente importante, aqui, é o processo partilhado de construção de conhecimentos, no qual as interlocuções entre aprendizes, de modo absolutamente singular, exercem um papel preponderante também nos processos individuais. É por essa razão que a análise será feita com base nos processos de interação entre as crianças que compõem uma parceria. Interessa considerar as discussões que se instauram e o tipo de questão que dá origem a elas (aspectos referentes ao conteúdo, à grafia das palavras, á estrutura dos textos etc.). Tal análise levará em conta tendências mais comuns entre os diferentes processos interlocutivos: quais as questões mais tematizadas entre as parcerias ao longo das produções dos quatro textos.

Em virtude da complexidade dos aspectos que envolvem a produção textual, os dados identificados como mais regulares serão discutidos em dois capítulos: um evidenciando aspectos de ordem discursiva e outro evidenciando aspectos notacionais. Essa opção será mais bem detalhada no início do capítulo 4.

As propostas de produção escrita eleitas também merecem uma justificativa. Em se tratando de uma pesquisa de cunho didático, a opção foi apresentar situações em que escrever 
tivesse um propósito específico e para as quais as tarefas exigidas se configurassem como familiares levando em conta o que vivenciam as crianças em sala de aula. O objetivo era justamente identificar quais preocupações e reflexões podem ser explicitadas por esses aprendizes na elaboração de textos e, conseqüentemente, se tornar focos de intervenção docente.

Os textos solicitados (listas e parlendas) também eram familiares às crianças, conforme já se afirmou, e tinham propósitos diferenciados: as listas seriam retomadas por todo o grupo-classe para a composição de uma listagem única de bagagem a apoiar, de fato, a organização da viagem para o acampamento. Nesse caso, os textos seriam conhecidos, inclusive, por leitores externos à sala de aula, como os pais. Já as parlendas tinham um objetivo comunicativo mais restrito, pois apenas seriam apresentadas na sala de aula por seus escritores, sem que houvesse uma efetiva necessidade de retomada por outros leitores. Essa diferença nos propósitos comunicativos, além do fato do conteúdo ser criado (nas listas) ou apenas recuperado de memória (nas parlendas) e das produções serem realizadas no papel ou no computador, eram aspectos a ser analisados na pesquisa.

Analisar esses importantes aspectos e compreender melhor as idéias e possibilidades infantis poderá contribuir para uma possível e necessária ressignificação do ensino da escrita em um contexto construtivista.

\subsection{HIPÓTESES E OBJETIVOS}

Tomando como base os pressupostos explicitados, a pesquisa que ora se apresenta parte de duas hipóteses. Em primeiro lugar, a de que o processo de produção textual, vivenciado em uma situação interlocutiva (instaurada de dois modos: a comunicação de uma mensagem via um texto escrito e a comunicação entre as crianças ao elaborá-lo) e sob condições específicas e também diferenciadas (o que inclui o tipo de texto que elaboram e os recursos do qual dispõem), favorece o surgimento e o enfrentamento de diversos problemas a ser considerados pelas crianças na construção da escrita.

Como segunda hipótese, postula-se que a produção escrita realizada em parcerias é favorável à situação didática, pois pode gerar a discussão acerca de problemas que encontram no processo de elaborar um texto. Propor, acompanhar e avaliar essas situações pode permitir aos educadores uma compreensão mais ampla da natureza, dimensão dos processos de apropriação do 
sistema de representação e das formas que toma a depender das características das situações comunicativas.

Como já citado, a pesquisa visa a analisar o processo interlocutivo de duplas de crianças, entre 4 e 6 anos aproximadamente, que possuem conceitualizações diferentes em relação ao sistema de representação alfabético e, da mesma forma, trilham caminhos diferentes, buscando apropriar-se desse objeto e de suas formas de uso. Pretende-se mapear algumas possibilidades diferenciadas de interação com a escrita, para evidenciar a dimensão cognitiva do processo de reflexão e de construção vivido pelas crianças. Dessa forma, tem o propósito maior de ampliar os conhecimentos de professores sobre aspectos a ser favorecidos em sala de aula, atentando para diversas variáveis e expectativas, dentro de uma abordagem construtivista de ensinoaprendizagem. Com esse trabalho, procurar-se-á verificar:

$\checkmark$ Se, estando em situações diversas de interação com a escrita, as crianças observadas também realizam reflexões diferenciadas sobre os problemas que escrever lhes impõe: decidir com quantas e quais letras se escreve uma dada palavra, decidir sobre o conteúdo do texto e sobre sua organização em tipos de textos pré-definidos, com variações de características e de propósitos.

$\checkmark$ Se a divisão de tarefas na parceria, uma criança ditando e outra escrevendo, é suficiente para que elas troquem informações sobre os problemas acima listados e sobre as soluções que podem dar a eles.

$\checkmark$ Se os problemas enfrentados são diferentes quando dominam o texto de memória e quando precisam decidir o seu conteúdo.

$\checkmark$ Se o fato das crianças estarem preocupadas com propósitos comunicativos diferentes, ora envolvendo outros leitores, ora apenas os próprios escritores, influencia o percurso de composição do texto.

$\checkmark$ Se a interação entre as crianças torna-se mais ou menos ampla na medida em que possuem conceitualizações mais avançadas sobre o princípio alfabético.

$\checkmark$ Se a interação com a escrita no papel e com a escrita no computador favorece reflexões diferenciadas sobre os problemas que vivenciam e as decisões tomam.

$\checkmark$ Se a interação entre as crianças se modifica a depender do recurso de produção disponível (papel ou computador). 
$\checkmark$ Como as crianças lidam com a necessidade de utilização de dois sistemas de representação, ao ter que grafar numerais e palavras em um mesmo texto.

Para analisar tais aspectos, foram tomadas decisões de ordem metodológica, explicitadas no próximo tópico.

\subsection{METODOLOGIA}

Conforme já foi destacado anteriormente, a pesquisa em questão pauta-se numa análise qualitativa dos dados coletados, já que para essa investigação importa a qualidade da interação estabelecida entre as crianças-escritoras e entre elas e as diferentes variáveis determinadas para as situações de produção textual.

O foco de análise será a interlocução entre a parceria durante o processo de produção dos textos solicitados. Toma-se como premissa que somente ao longo do processo de elaboração do texto, quando problemas surgem e são expostos pelas crianças em suas tentativas de solucionálos, é que se pode observar, registrar e avaliar os intercâmbios e a qualidade da interação com a escrita que foi negociada. Julga-se, enfim, que o texto acabado é o resultado da produção e sua análise isolada não traz à luz o percurso que trilharam seus autores a fim de construí-lo.

Para que as crianças de cada dupla pudessem vivenciar conflitos, explicitá-los e discutir propostas de solução, era fundamental, antes de tudo, que a produção de um texto se colocasse para elas como uma situação-problema. Necessariamente era preciso que as crianças não tivessem de antemão, de maneira automatizada, soluções prontas para todos os problemas que a escrita pudesse lhes trazer. Isso porque as propostas didáticas que, de fato, podem propiciar conflitos e gerar novas aprendizagens são mesmo aquelas que se configuram como problemas para os aprendizes. Afinal, de acordo com a "perspectiva construtivista, o conhecimento só avança quando o aprendiz tem bons problemas sobre os quais pensar” (WEISZ; SANCHES, 2000, p. 66).

São situações dessa natureza que merecem uma análise mais aprofundada de forma a ampliar os conhecimentos dos professores e favorecer as opções e decisões que devem tomar em suas intervenções no processo de apropriação da escrita. De acordo com Pozo (1998, p. 16)

[...] uma situação somente pode ser concebida como um problema na medida em que exista um reconhecimento dela como tal, e na medida em que não 
disponhamos de procedimentos automáticos que nos permitam solucioná-la de forma mais ou menos imediata, sem exigir, de alguma forma, um processo de reflexão ou uma tomada de decisões sobre a seqüência de passos a serem seguidos.

Sabe-se, porém, e cabe fazer essa ressalva, que nem sempre uma mesma situação pode se constituir como situação-problema para todas as crianças. Para algumas, pode estar além de suas possibilidades por não contarem com um repertório de conhecimentos que lhes permita lidar com os problemas que se colocarão. Para outras, que já tenham soluções automatizadas, a tarefa em jogo será somente um exercício, um treino para que coloquem em prática o que já construíram. Coloca-se como crucial reconhecer essa questão e considerá-la tanto nas análises que serão feitas nessa pesquisa quanto nas propostas didáticas que se realizam em sala de aula.

Na análise dos percursos de composição dos textos, buscar-se-á identificar as tendências nas observações e reflexões explicitadas pelas crianças tanto no que diz respeito à necessidade de tomar decisões referentes ao próprio sistema de representação, como no que tange à situação comunicativa específica em que se encontravam e o texto que compunham.

Em paralelo às regularidades, não se pode descartar a natureza singular dos processos vividos pelas duplas a cada situação proposta. Ainda que reflexões comuns se instaurem, nem sempre as soluções dadas pelas diferentes duplas para compor o texto se assemelham. Isso porque dependem das hipóteses das crianças no momento da produção e das interações estabelecidas, entre outros aspectos, o que permite afirmar que se tratam de processos de interação e interlocução bastante particulares.

Feitas essas considerações, é preciso, agora, discorrer sobre o ambiente escolar no qual estudam as crianças, e mais especificamente sobre o trabalho feito na área de linguagem que certamente influenciou suas atuações nas propostas de escrita. Do mesmo modo, é interessante dispor de algumas informações sobre as crianças que se constituíram sujeitos dessa pesquisa. Esses são os propósitos norteadores do capítulo que se segue. 


\title{
3 A ESCOLA E AS CRIANÇAS
}

\author{
Qual é a única maneira de permitir a alguém - \\ criança ou adulto - que aprenda algo a respeito \\ de certo objeto de conhecimento? Permitir-lhe \\ que entre em contato, que interaja com esse objeto.
}

(FERREIRO, 2003, p. 38)

Como se destacou no capítulo anterior, a Escola eleita para a realização da pesquisa evidencia-se por ser um importante centro de trabalho e investigação, tomando como referência o construtivismo. Com base nessa concepção, o que caracteriza o projeto educativo da Escola da Vila é a incessante busca por uma prática didática que instigue a construção significativa e compartilhada de conhecimentos por parte dos alunos.

As reflexões, discussões, comentários e decisões reveladas pelas crianças ao longo dos processos de elaboração dos textos, analisados na presente pesquisa, explicitaram, em vários momentos, apropriações de procedimentos e atitudes aprendidas no âmbito escolar e que favorecem suas atuações como autoras, assim como as aproximam da compreensão acerca do sistema de escrita e de suas práticas sociais de uso.

É por essas razões, e para que melhor se entenda parte das reflexões realizadas pelas crianças observadas, que este capítulo terá como foco apresentar, em linhas gerais, a proposta pedagógica da Escola da Vila para o ensino da língua escrita, bem como sua caracterização (localização e clientela). Em igual medida, torna-se importante conhecer melhor as crianças que constituem os sujeitos desta pesquisa em suas ações como escritoras. As informações aqui fornecidas de modo genérico certamente poderão ser retomadas e ampliadas nos capítulos seguintes, na específica relação com a análise dos dados coletados.

Outro aspecto que ganha relevância no capítulo que se inicia é discorrer sobre o processo de conceitualização da escrita, pois fundamentará análises sobre parte das decisões tomadas pelas crianças em suas produções escritas.

\subsection{A ESCOLA E A CONSTRUÇÃO DE CONHECIMENTOS}

Ao se considerar cada sujeito aprendiz, o processo de construção de conhecimentos evidencia-se, de fato, como um percurso singular e único. Do ponto de vista interno, as crianças 
trilham caminhos cognitivamente diversos, criando hipóteses e alternativas, para se apropriar da escrita convencional e se tornar escritoras hábeis na comunicação via textos, conforme já se explicitou no capítulo 1. Do ponto de vista externo, também é verdade que as experiências que vivenciam em diferentes contextos podem enriquecer e favorecer esse processo. Importa salientar o quanto esses dois aspectos estão interligados no processo de aprendizagem do sujeito: as reflexões, conceitualizações e estratégias que, internamente e de modo gradativo, ele é capaz de construir têm como base o que observa e experimenta em sua relação com o mundo da escrita. Contatos freqüentes e significativos com os textos escritos, em estreita sintonia com as suas funções, tendem a ampliar a inserção da criança em sua cultura letrada.

Do modo como hoje se organiza, a escola pode exercer dois papéis na vida dos alunos e alunas. Por um lado, ciente da natureza do processo de aprendizagem, pode reconhecer sua intervenção integrante nesse processo de construção de saberes, entendendo que o conhecimento transcende a experiência escolar espacial e temporalmente. Isso quer dizer que a escola se coloca como parte da experiência dos aprendizes para expandir o universo de informações e promover situações que contribuam para a participação ativa desses sujeitos. Inversamente, em uma perspectiva transmissiva de conhecimentos, a escola pode posicionar-se como única informante, única fonte de aprendizagem, contrariando até os saberes construídos pelas crianças antes de iniciar sua escolaridade.

$\mathrm{Na}$ pesquisa que aqui se apresenta, a opção foi tomar a escola como um espaço privilegiado de experiências, com o universo da escrita e com outros escritores e leitores, cuidadosamente planejadas, de modo a entender a criança como um ser pensante que (re) constrói ativamente os conhecimentos. Por essa razão, elegeu-se, dentre outras possibilidades, a Escola da Vila, uma instituição que reconhecidamente considera a criança como centro do processo de aprendizagem, que respeita e leva em conta os saberes já apropriados pelos aprendizes, ainda que de modo não convencional, tomando-os como ponto de partida e propiciando situações didáticas com o intuito de ampliá-los. Nessa escola, escrever e ler são tarefas propostas desde as séries iniciais, antes mesmo que compreendam o princípio alfabético.

As oito duplas de crianças que fizeram parte das propostas desta pesquisa foram compostas pelas professoras de classe com base em critérios que, usualmente, são considerados pela escola para favorecer intercâmbios na produção escrita: proximidade em relação ao momento conceitual de apropriação do sistema alfabético, postura perante as atividades de escrita 
e leitura, possibilidade de atuação em parcerias de trabalho. Nesses critérios de agrupamento, leva-se em conta a autonomia das crianças, a demanda em relação à presença do professor, a confiança em seu próprio saber, a disponibilidade para com o colega, entre outros aspectos. As professoras de ambas as classes selecionadas - Grupo 3 e Grupo 4 - fizeram uma breve descrição das crianças em função do que avaliavam rotineiramente, observando suas produções escritas e a forma como atuavam nas propostas didáticas que lhes eram apresentadas.

No que se refere ao processo de apropriação do sistema de escrita, as professoras adotam como referência - e o mesmo se faz na presente pesquisa - os três grandes momentos conceituais, descritos por Ferreiro e Teberosky (1995) em suas observações e avaliações sobre as crianças. Pela relevância que terá o processo de conceitualização da escrita alfabética nesse trabalho, justifica-se uma breve apresentação desse referencial, situando o processo conceitual exposto pelas autoras.

\subsection{BASES PARA A COMPREENSÃO DO PROCESSO DE CONSTRUÇÃO DA ESCRITA}

Como momento inicial desse processo, é preciso que as crianças entendam a escrita como um sistema de representação: um conjunto de símbolos particulares que, compondo uma palavra de nossa Língua, diz algo, tem sentido. E como um sistema peculiar, escrever difere de desenhar, por exemplo, descoberta que, muitas vezes, as crianças podem fazer bem cedo. Nesse primeiro momento de conceitualização da escrita, a criança julga que escrever é nomear e, inúmeras vezes, pode realizar correspondências gráficas entre características do objeto a ser representado e sua escrita, como seria o esperado no desenho: para escrever "elefante”, os traços precisam ser mais prolongados do que para escrever "abelha”, marcando a diferença de tamanho entre os dois animais. É comum que utilizem como marcas gráficas seqüências de bolinhas, traços ou mesmo traçados lineares e contínuos, imitando a grafia em letra cursiva que observam nos adultos.

Em um segundo momento conceitual, as crianças descobrem a necessidade de variar as grafias se desejam escrever coisas diferentes. Uma mesma seqüência de traçados não pode ser lida de duas formas diversas; para que se escreva palavras diferentes, são necessários conjuntos de símbolos diferentes. Também é preciso haver uma quantidade mínima de símbolos para que algo esteja escrito e possa ser interpretável. Estão em construção, nesse momento inicial, as idéias 
de legibilidade e o caráter interpretativo que marcam, de fato, nosso sistema de escrita. Lemos da mesma maneira dois conjuntos iguais de letras e colocadas na mesma ordem, e a maior parte dos vocábulos de nossa Língua é mesmo grafada com mais de três letras.

A necessidade de variar suas escritas internamente - utilizando símbolos diferentes para compor uma palavra - e externamente - com seqüências variadas para compor palavras diferentes - faz as crianças buscarem novos símbolos para suas representações, ou seja, aumentarem o repertório dos símbolos que usam para escrever. O aparecimento das primeiras letras convencionais, ou até de traçados que a elas se assemelhem, tende a acontecer nesse momento. Além disso, é muito comum que as crianças experimentem recortes quando grafam as palavras que desejam. Isso quer dizer que já podem se ocupar de pensar sobre partes das palavras enquanto as grafam. Ao contrário do que se julgou durante um certo tempo, as crianças que constroem esses saberes também podem se preocupar com a relação entre as palavras e o som a representar, embora não o façam de modo silábico ou convencional. Para escrever “soldado”, por exemplo, essas crianças podem pensar em escrever inicialmente SOL, e depois o restante, DADO ou, SOLDA e, em seguida, DO. Enfim, são muitas as possibilidades de recortes ainda não tão centrados na análise de cada sílaba emitida sonoramente, mas que muito contribuem para essa aquisição. Como as idéias de quantidade e variedade já apropriadas por essas crianças marcam forte presença em sua concepção sobre a escrita, o emprego de um vasto repertório de letras para cada palavra se mantém, ainda que com essas segmentações. Isso significa que ainda não limitam suas grafias à quantidade de sons que desejam grafar, optando por uma quantidade maior de símbolos para compor suas escritas (Cf. VERNON, 1998).

Mais uma conquista conceitual importante nesse processo de compreensão do sistema alfabético está na tentativa de atribuir valores sonoros às letras, agora em busca de uma segmentação mais refinada. A criança procura identificar, sonoramente, a representação a ser utilizada para compor sua escrita. Essa é realmente uma árdua tarefa para as crianças, principalmente para aquelas que aplicam ainda um repertório restrito de letras em suas produções. É comum que se ocupem das vogais, por se tratarem de sons mais estáveis, embora algumas crianças, a depender do tanto que conhecem sobre as letras e sobre a escrita convencional de determinadas palavras, possam optar pelas consoantes. Nas duas possibilidades, as crianças passam a usar uma só representação gráfica para cada sílaba da palavra que querem grafar, passando a realizar uma segmentação silábica das palavras. Ainda que a criança não 
contemple, inicialmente, partes menores do que as sílabas, ela começa a compreender nesse momento o que é realmente um dos princípios mais importantes que rege o sistema alfabético: a relação fonema-grafema. Duas palavras podem ser iniciadas com as mesmas letras se tiverem o mesmo som, mesmo que sejam completamente distintas em seus significados. Até aqui, a criança ainda está focada na relação entre a sílaba e o som, mas já manifesta sua preocupação em vincular a análise sonora à produção escrita, algo essencial ao sistema alfabético.

Ainda que muitos conceitos tenham sido construídos até então, a criança deve descobrir que a análise sonora a ser feita precisa ir além da sílaba. Nessa fase, a criança retoma conceitos já apropriados, não raro relacionados às contradições geradas pela coexistência de hipóteses como a da quantidade mínima de caracteres para se escrever e a da necessidade de variá-los. As escritas pautadas na análise silábica acabam por ser marcadas pela pequena extensão, já que uma palavra com quatro sílabas terá apenas quatro letras (ou símbolos que ainda podem ser utilizados) em sua representação. Ademais, dificulta a variedade, pois diversas serão as palavras que poderão ser grafadas da mesma forma: “pato”, “mato”, “taco”, “dado” e "sapo” podem, segundo esse critério, ser escritas igualmente com AO (A para pa, ma, ta, da e sa e O para to, co, do e po). O conflito que se instaura entre a escrita pautada pela análise sonora das sílabas e a necessidade de variar as grafias e utilizar um conjunto maior de símbolos, para que algo possa ser lido, tende a favorecer a inserção de outras letras nas palavras que são escritas; gradativamente, a criança se aproximará de uma escrita alfabética, estabelecendo muitas vezes comparações entre o que deseja grafar e palavras cuja escrita já domina.

Importante salientar que não se trata de uma construção necessariamente linear, etapa por etapa. Conforme já explicitado, a construção de conhecimentos é um processo individual e singular. Algumas crianças certamente poderão apresentar um processo de construção conceitual da escrita mais próximo ao aqui descrito. Outras, porém, poderão realizar conceitualizações paralelas, vinculando ainda a grafia a características do objeto, e, simultaneamente, ser capazes de realizar comparações sonoras entre palavras da nossa língua. Reconhecem que "baleia” e “batom”, que nada se assemelham em significado, são escritas em seu início da mesma forma.

Com base nessas referências, é importante conhecer melhor as crianças observadas e analisadas nas situações de pesquisa a partir de informações dadas por suas professoras. 


\subsection{CONHECENDO OS ALUNOS}

No quadro que se segue, as crianças serão apresentadas por meio de informações dadas por suas professoras, tendo como base as avaliações feitas no mês de Abril, quando iniciaram-se as propostas da pesquisa.

\section{QUADRO 2 - INFORMAÇÕES SOBRE OS ALUNOS}

\begin{tabular}{|c|c|c|}
\hline Duplas & Alunos & Informações relativas às atuações em produções escritas \\
\hline 1 & $\begin{array}{l}\text { Giulia (3/ 5.9) }{ }^{10} \\
\text { Guilherme (3/5.5) }\end{array}$ & $\begin{array}{l}\text { Giulia e Guilherme já realizam uma análise silábica em relação à escrita e } \\
\text { tendem a atuar com autonomia nas propostas de produção em classe. Ambos } \\
\text { demonstram grande preocupação em grafar as palavras segundo os critérios } \\
\text { que já dominam. }\end{array}$ \\
\hline 2 & $\begin{array}{l}\text { Daniel (3/5.7) } \\
\text { Flora (3/4.11) }\end{array}$ & $\begin{array}{l}\text { Daniel e Flora também apresentam uma produção de caráter silábico, embora } \\
\text { nem sempre com valor sonoro convencional, e demonstram grande } \\
\text { preocupação em levar em conta esse critério em suas produçôes. Porém, já } \\
\text { começam a aceitar a grafia de sons com mais de uma letra. Flora costuma ter } \\
\text { uma certa dificuldade para dividir tarefas com colegas, pois gosta de tomar } \\
\text { sozinha todas as decisões. }\end{array}$ \\
\hline 3 & $\begin{array}{l}\text { Beatriz (3/4.10) } \\
\text { Luiz (3/ 5.5) }\end{array}$ & $\begin{array}{l}\text { Beatriz demonstra segurança ao escrever, mas é comum cansar-se } \\
\text { rapidamente e reclamar ao ter que atuar em propostas de escrita. Além disso, } \\
\text { dispersa-se facilmente. Encontra-se em um momento inicial de } \\
\text { conceitualização e mescla uso de letras e outros símbolos em suas produções. } \\
\text { Luiz preocupa-se com a variedade e a quantidade de letras em suas escritas e } \\
\text { abandonou recentemente o uso de outros símbolos, passando a utilizar } \\
\text { somente as letras convencionais. }\end{array}$ \\
\hline 4 & $\begin{array}{l}\text { Pedro (3/5.4) } \\
\text { João (3/5.4) }\end{array}$ & $\begin{array}{l}\text { Pedro tem uma fala com omissão de muitos sons e se dispersa nas atividades, } \\
\text { iniciando outros assuntos durante as tarefas. Já demonstra uma preocupação } \\
\text { em relacionar a quantidade de sons à quantidade de letras e está cada vez } \\
\text { mais ocupado também em buscar precisamente os sons para conseguir } \\
\text { corresponder parte de sua representação. } \\
\text { João apresenta uma produção com análises silábicas e utiliza letras com valor } \\
\text { sonoro convencional. Atua de forma muito segura e tende a solicitar a } \\
\text { participação dos colegas que dividem com ele a tarefa de escrever. }\end{array}$ \\
\hline 5 & $\begin{array}{l}\text { Camila }(4 / 6.7)^{11} \\
\text { Jhoão }(4 / 6.6)\end{array}$ & $\begin{array}{l}\text { Camila já procura realizar uma análise dos sons além da sílaba, podendo } \\
\text { grafar alfabeticamente muitas palavras, ainda que com algumas omissões } \\
\text { esperadas para esse momento. Atua com segurança, mas tende a trabalhar } \\
\text { sem trocar informações com seus parceiros. } \\
\text { Jhoão já apresenta uma produção alfabética e sistemática. Arrisca-se a ler o } \\
\text { que escreve e já localiza, em algumas escritas, omissões que comprometem a } \\
\text { compreensão. }\end{array}$ \\
\hline
\end{tabular}

${ }^{10}$ (3/5.9): Informações correspondentes à série e idade. Ex.Grupo 3/ 5 anos e 9 meses 


\begin{tabular}{|c|l||l|l|}
\hline 6 & $\begin{array}{l}\text { Antonio (4/6.9) } \\
\text { Bruno (4/5.10) }\end{array}$ & $\begin{array}{l}\text { Ambos possuem uma produção alfabética, mas Bruno mostra-se mais atento à } \\
\text { quantidade necessária de letras e às representações convencionais. Às vezes, } \\
\text { já consegue ler suas produções, ao contrário do colega que ainda não se } \\
\text { arrisca na leitura. }\end{array}$ \\
\hline 7 & $\begin{array}{l}\text { Angela (4/5.10) } \\
\text { Vitor (4/6.3) } \\
\text { ritor atua com pouca segurança nas produções. Chegou na escola neste ano e } \\
\text { repertório pequeno de letras e se sente pouco confiante ao realizar produções } \\
\text { escritas. Sem ajuda, apresenta uma produção em que começa a se preocupar } \\
\text { com a necessidade de variedade e quantidade. } \\
\text { Angela está começando a relacionar a quantidade de sons à quantidade de } \\
\text { letras (realizando uma análise silábica), ainda que não dê conta dessa tarefa } \\
\text { sistematicamente. Mostra-se bastante segura e à vontade para escrever e, } \\
\text { ainda, aprecia atuar como informante de seus colegas. }\end{array}$ \\
\hline 8 & $\begin{array}{l}\text { Pedro H. (4/5.9) } \\
\text { Clara (4/5.7) }\end{array}$ & $\begin{array}{l}\text { Pedro H. e Clara apresentam uma produção marcada pela análise silábica. } \\
\text { Porém, em alguns momentos, já começam a se preocupar com a necessidade } \\
\text { de mais letras. Ambos evidenciam um interesse grande pelas atividades de } \\
\text { escrita. }\end{array}$ \\
\hline
\end{tabular}

Essas informações foram utilizadas como referência para a formação das parcerias e também como fundamentação para as observações iniciais nas situações de pesquisa.

\subsection{O TRABALHO COM A LÍNGUA NA ESCOLA DA VILA}

A Escola da Vila é uma instituição com vinte e seis anos de tradição. Mantém duas unidades, oferecendo desde a Educação Infantil até o Ensino Médio. Sua clientela inclui famílias de classe média e classe média alta. A unidade onde se realizou a pesquisa localiza-se no bairro do Butantã, em São Paulo, e atende não apenas a famílias residentes na região, mas também a outras vindas de partes mais distantes da cidade.

A escola promove um trabalho intenso e sistemático de aproximação das crianças com a língua escrita. Os alunos e alunas são tomados, desde o início da escolaridade, como leitores e escritores em situações nas quais são estimuladas oportunidades de interpretação e produção textual. São atividades organizadas de modo que possam ampliar seus conhecimentos sobre os textos e seus propósitos sociais, bem como sobre o sistema de representação e seus princípios. Tem-se por premissa a necessidade de diversas experiências das crianças com a língua escrita.

A esse respeito, vale lembrar a distinção feita por Kramer (In: ZACCUR, 1999) entre “vivência” e "experiência” para definir a natureza do esforço pedagógico de alfabetização. Mais

\footnotetext{
${ }^{11}$ (4/6.7): Informações correspondentes à série e idade. Ex. Grupo 4/ 6 anos e 7 meses
} 
do que uma simples vivência de escrita, o ensino deve propor situações de reflexão que superem a necessidade mais imediata e pontual do aluno-escritor, ou seja, uma efetiva experiência, como situa a autora:

Quando penso na escrita como experiência, refiro-me a situações em que o vivido assume uma dimensão para além do finito, contando-se no texto. O que faz de uma escrita uma experiência é o fato de que tanto quem escreve quanto quem lê enraízam-se numa corrente constituindo-se com ela, aprendendo com o ato mesmo de escrever ou com a escrita do outro, formando-se. (p. 110)

Incorporando o princípio de valorizar a experiência com a escrita, a Escola da Vila procura, desde o início da Educação Infantil, cultivar a sintonia entre a intervenção pedagógica e a própria razão de escrever. É o que propõem as diretrizes de ensino construtivistas, conforme ilustra o seguinte exemplo:

En la escuela las prácticas de lectura y escritura son abordadas como prácticas sociales. [...]

Es responsabilidad de la escuela que los niños comiencen a ejercer los quehaceres que todo lector y todo escritor ponen en juego, y que sean desde el comienzo, aun cuando no se hayan apropiado todavía del sistema notacional, auténticos lectores y escritores - principiantes, desde luego - que leen o escriben con propósitos definidos, que integran con sus compañeros de sala e sus docentes una comunidad de lectores y escritores. (SECRETARIA DE EDUCACIÓN DE LA CIUDAD DE BUENOS AIRES, 1999, p. 303) ${ }^{12}$

Tem-se a escrita como um verdadeiro sistema de representação sobre o qual não se pode refletir sem sua inserção em circunstâncias reais de uso. Desde o início da escolaridade, as crianças participam de situações, criteriosamente planejadas, em que escrevem e lêem por si mesmas e outras em que escrevem textos ditando-os para o professor e ouvindo leituras feitas por ele. Os textos não são apresentados ou trabalhados distantes de seus propósitos sociais: ouve-se textos narrativos apenas por deleite, para apreciação; ouve-se trechos de textos informativos porque se quer buscar algum dado de caráter preciso, sobretudo atrelado a propostas de pesquisa;

\footnotetext{
12 “Na escola, as práticas de leitura e escrita são abordadas como práticas sociais. [...]

É responsabilidade da escola que as crianças comecem a exercer os procedimentos que todo leitor e todo escritor põem em jogo, e que sejam, desde o começo, ainda que não tenham se apropriado do sistema notacional, autênticos leitores e escritores - principiantes, naturalmente - que lêem ou escrevem com propósitos definidos, que integram com seus companheiros e com seus professores uma comunidade de leitores e escritores.” (tradução livre - Andréa Luize)
} 
ouve-se textos instrucionais, pois se quer aprender ou executar um jogo ou uma receita, por exemplo. Sozinhas ou em pequenos agrupamentos, as crianças também experimentam situações em que devem ler por si mesmas, mesmo que não o façam de modo convencional. Selecionam, dentre vários títulos conhecidos, aqueles que querem escutar novamente nas rodas de leitura diárias; são convidadas a eleger, dentre dois ou três, um jogo que muito apreciam para repeti-lo num dado momento; precisam identificar onde está escrita a parlenda recitada pela professora, dentre duas ou três possibilidades, entre outras tarefas.

Do mesmo modo, produzem textos sob a consigna "escrevam da melhor forma que sabem” ou “como lhes parece que se deve escrever”, elaborando listagens de títulos de histórias apreciados, pequenos registros de pesquisas, nomes de animais que estão estudando ou desejam estudar, brincadeiras com rimas etc. Também ditam para o professor textos de circulação cotidiana como cartas, convites ou bilhetes, sempre que se fazem necessários, e ainda legendas informativas, histórias conhecidas, entre outros.

À medida que avançam na escolaridade, as crianças passam a escrever e ler por si só, cada vez com mais freqüência, e vão sendo igualmente convidadas a ler e escrever textos mais complexos pelas mãos do professor ou com seu apoio. Com igual ênfase, as crianças vivenciam situações formais de uso da fala e da escuta: assistem a breves seminários, organizam e realizam entrevistas, preparam recitais de poemas etc.

Boa parte dos conteúdos trabalhados na área de Língua organiza-se em projetos didáticos, de forma que textos orais e escritos sejam produzidos e interpretados em contextos reais; as crianças são convidadas a refletir sobre todos os problemas que vivenciam escritores, leitores, falantes e ouvintes quando têm a tarefa de compreender ou comunicar algo dito ou escrito por outros ou para outros. Elas discutem problemas que a produção de um texto lhes traz e, em meio a intervenções do professor, vão buscando coletivamente maneiras de solucioná-los para efetivarem a comunicação que se deseja. Produzem, assim, livros de histórias ou de brincadeiras rimadas com os quais presenteiam seus familiares, murais informativos para apreciação da comunidade escolar e tantos outros textos em diferentes portadores.

Os problemas que discutem acerca das produções escritas e das situações de leitura são tanto atrelados à natureza do sistema notacional quanto à língua que se escreve, considerando-se o tipo de texto que está sendo elaborado. Duas crianças com idéias próximas sobre como se escreve as palavras no nosso sistema podem ter como desafio chegar a um acordo sobre a grafia 
do nome do animal que pesquisam e sobre o qual precisam escrever uma legenda; podem refletir e confrontar suas hipóteses sobre com quantas e quais letras escrever. Simultaneamente, podem discutir a melhor forma de transformar em texto escrito uma informação sobre a alimentação desse animal; podem refletir sobre a estrutura e a linguagem pertinente a um breve texto de caráter informativo, aperfeiçoando-se nos seus conhecimentos sobre a língua escrita.

A Escola em questão entende que, atuando como leitoras e escritoras sob intervenções e mediações do professor em situações didáticas amplamente favoráveis, as crianças não só avançam na compreensão do princípio alfabético do nosso sistema, aproximando-se passo a passo da escrita convencional, como se inserem no universo dos textos que se escreve socialmente, decifrando seus propósitos e características. Em síntese, a escola impõe-se como tarefa

[...] fazer as crianças participarem de situações de leitura e de escrita: é necessário pôr a sua disposição materiais escritos variados, é necessário ler para elas muitos e bons textos para que tenham oportunidade de conhecer diversos gêneros e possam fazer antecipações fundadas nesse conhecimentos... É necessário lhes propor também situações de produção que lhes apresentarão o desafio de compor oralmente textos com destino escrito - para serem ditados ao professor, por exemplo-: no curso dessa atividade serão apresentados problemas que as levarão a descobrir novas características da língua escrita e a se familiarizar com $\mathrm{o}$ ato de escrita, antes de saberem escrever no sentido convencional do termo (LERNER, 2002, p. 41).

Cabe ainda destacar um outro trabalho encaminhado por essa escola que muito favorece reflexões sobre nosso sistema de representação. Segundo a pesquisa psicogenética centrada na Língua identificou, o nome próprio funciona como uma das primeiras escritas estáveis e munidas de sentido para as crianças (Cf. FERREIRO; TEBEROSKY, 1999).

Na Escola da Vila, o trabalho com os nomes próprios é tido como fundamental e benéfico em inúmeros sentidos. Em primeiro lugar, pela grande importância quando do ingresso na escola, por identificar a criança e tudo o que lhe pertence: pastas, cadernos, desenhos, lancheira, cabide, tudo recebe uma mesma identificação; uma mesma palavra permite que todos reconheçam o "dono" ou a "dona” do material.

Em segundo lugar, essa tarefa de identificação não só se justifica enquanto necessidade social, mas também se impõe como uma exigência da própria criança:

Muitos psicólogos constataram, também, a precoce tendência infantil a 'marcar' as produções gráficas iniciais, sobretudo os desenhos. [...] Essa habilidade 
começa por volta dos três anos e, em muitos casos, antes. A que se deve essa necessidade precoce de marcar as próprias produções? Essas marcas não são ainda a representação da pauta sonora do nome. A função é, primordialmente, a identificação da produção, a de colocar a marca de propriedade (TEBEROSKY, 1990, p. 32).

A construção da identidade, pela própria criança, passa ainda pela necessidade de ser reconhecida por seu próprio nome, razão igualmente importante para se evidenciar essa escrita no início da escolaridade.

Do ponto de vista da Língua, sabe-se que, em momentos iniciais de construção da escrita, as crianças atribuem a ela a função de denominação:

\begin{abstract}
a primeira idéia das crianças é que substantivos e nomes próprios é aquilo que está escrito. Nesse caso, dizemos que, além de atribuir ao texto uma intenção comunicativa, pensam que sua função é a de 'denominar' os objetos presentes na imagem ou no contexto. O texto diz 'o que é' um objeto. [...] Diferentemente do desenho que representa objetos, as letras representam a propriedade que o desenho não pode representar: seus nomes [...] (TEBEROSKY, 2003, p. 48).
\end{abstract}

Ainda em se tratando da aprendizagem da linguagem escrita, o nome da criança pode atuar como um primeiro modelo de grafia estável: não importa o que está a identificar, terá sempre as mesmas letras apresentadas na mesma seqüência. Vivenciar propostas em que tenha que localizar sua folha de desenho ou seu lugar na mesa pela identificação do nome; observar outras pessoas grafando seu nome; organizar a lista de alunos presentes e ausentes naquele dia utilizando fichas de nomes; ter o desafio de identificar seu nome ou de um colega tendo apenas parte da grafia à mostra e outras situações similares possibilitam à criança, gradativamente, se apropriar da grafia convencional de seu nome e passar a interpretá-lo, sem ajuda, em qualquer contexto. O mesmo se pode dizer da escrita do nome pela própria criança, tarefa que aos poucos exerce com autonomia, de início com uma grafia distante da convencional e dela se aproximando progressivamente. Já no princípio da educação infantil, pode-se ver crianças de 3 ou 4 anos capazes de grafar o seu nome e até de colegas ou familiares de modo convencional, embora não compreendam a escrita alfabética. Ao longo do processo empreendido para ler e escrever seus respectivos nomes, as crianças têm oportunidades de conhecer os símbolos utilizados em nosso sistema - as letras e acentos, por exemplo - e suas possíveis combinações, assim como as variações de quantidade e qualidade que o caracterizam, sem a exigência de uma apresentação formal de letras ou sílabas isoladas, em práticas artificiais e sem sentido. 
O trabalho com os nomes próprios, sob intervenções do professor, ganha também outras instâncias no processo cognitivo conforme as crianças avançam nas séries da educação infantil. Comparar sonora e graficamente nomes que começam da mesma maneira (Maria, Manuela e Mariana, por exemplo), buscar diferenças e semelhanças entre eles - na pauta sonora ou na representação gráfica -, ouvir a leitura de partes que compõem o seu nome (mar, Maria, Ana em Mariana; flor em Flora etc.), entre outras tarefas, levam a reflexões intensas não apenas sobre essas palavras, mas sobre princípios que regem nosso sistema, tais como: descobrir que, mesmo compondo nomes diferentes e se referindo a crianças diferentes, o MA será grafado da mesma maneira; descobrir que o significado da palavra não é um critério preciso para compor sua grafia (duas palavras podem combinar sonora e graficamente mesmo que representem pessoas diferentes: Manuel e Manuela).

Refletir sobre essas regularidades do sistema e, ao mesmo tempo, detectar irregularidades (como saber que “Teresa” e “Tereza” lê-se do mesmo modo) são aspectos potencializados pelo trabalho com nomes e poderão mais adiante ser ampliados pela mediação do professor: saber grafar corretamente um repertório de nomes pode apoiar a escrita de palavras novas que se deseja grafar. O trabalho com nomes promovido pela Escola enfática e sistematicamente nos primeiros anos da escolaridade, aos poucos, ganha outros rumos: essas palavras já tão conhecidas podem atuar como ponto de confronto entre a escrita convencional e as idéias infantis sobre como se escreve, pois se tornam fontes de consulta, de pesquisa para a grafia de outros vocábulos. É dessa maneira que as crianças são convidadas, em estágios mais avançados de seu processo de conceitualização da escrita, a refletir, por exemplo, sobre a grafia de "Manuel” se se quer escrever "maçã”: será que parte do nome do Manuel pode ajudar na escrita de parte da palavra maçã?

Esse trabalho também apoiará reflexões de caráter ortográfico que as crianças tendem a realizar, especialmente depois de apresentarem uma produção alfabética. Reconhecer a existência de duas grafias diferentes para representar um mesmo nome permite que observem essa possibilidade também em outras palavras e passem a explicitar questões nesse sentido (por exemplo, “mesa, é com S ou Z?”).

Em síntese, a escola acredita que o trabalho com as práticas sociais de leitura, escrita e oralidade - tomadas como conteúdos escolares, sem que se distanciem do que o são socialmente - e a inserção no universo dos nomes próprios, também incluída em situações reais de 
interpretação e produção, não apenas incentivam a reflexão metalingüística (e em particular o processo de conceitualização da escrita alfabética), mas também aumentam os conhecimentos das crianças em relação às práticas sociais que envolvem a escrita. Reconhecendo o caráter interno e individual do processo de construção de conhecimentos, a escola posiciona-se como um rico espaço de experiências significativas, estruturadas e planejadas pelo professor, que, em conjunto com outras experiências da criança, contribuirão para seus avanços e descobertas sobre a Língua e para a possibilidade de reflexões ainda mais elaboradas.

Presentes nesse contexto de trabalho pedagógico, as crianças selecionadas para a pesquisa participaram das quatro situações de produção textual previstas, sem que isso se configurasse uma novidade para elas. Usualmente, realizam produções de textos, inclusive lidando com diversos recursos que as viabilizem, como o processador.

No capítulo que se segue serão analisados os dados coletados nas situações de produção propostas para as oito duplas de crianças, considerando critérios estabelecidos a partir dos processos de elaboração dos textos e da produção propriamente dita. 


\section{O PROCESSO DE PRODUÇÃO TEXTUAL: TENDÊNCIAS NOS ASPECTOS DISCURSIVOS}

Para alfabetizar é preciso ter acesso à língua escrita (tanto como para aprender a falar é necessário ter acesso à língua oral) [...].

(FERREIRO, 2003, p. 34)

O capítulo anterior trouxe informações sobre as crianças, seus processos de construção conceitual em relação à escrita e também suas experiências escolares com os textos e suas funções, uma vez que esse conjunto de dados contribuirá para a análise que será feita.

As observações relativas ao processo de produção dos trinta e dois textos elaborados pelas oito duplas de crianças (duas listas e duas parlendas para cada dupla), as transcrições dos diálogos encadeados durante essa tarefa e os próprios textos em versão final permitem uma série de análises sobre as reflexões que esses pequenos escritores foram capazes de explicitar. Reflexões centradas na escrita das palavras, nas decisões sobre o conteúdo do texto, nas preocupações com seus destinatários e propósitos quando estabelecidos previamente. Com esse conjunto de dados foram estabelecidos critérios que possibilitam mapear as reflexões e tomadas de decisões por parte das crianças, tanto no que diz respeito aos aspectos discursivos na produção de listas e parlendas, e que serão focados no presente capítulo, quanto no que se refere aos aspectos notacionais nesses mesmos textos, que serão abordados no capítulo 5.

\subsection{UNIDADES DE ANÁLISE}

Conforme já citado nos capítulos anteriores, a proposta da presente pesquisa é analisar as reflexões que as crianças fazem ao ter que elaborar os textos solicitados. Como destaca Góes (In SMOLKA; GÓES, 2003, p. 101), considera-se que

a ação reflexiva pode ser entendida como aquela que é tomada como objeto de atenção pelo próprio sujeito. Trata-se não só de saber fazer, mas também de pensar sobre o que e como se faz. 
Busca-se identificar que aspectos do ato de escrever podem se tornar fontes de reflexão por parte dessas crianças e, conseqüentemente, alvos de intervenção didática e ampliação de conhecimentos. Sabe-se, porém, que a ação de escrever é apenas uma das tarefas que a comunicação escrita demanda de um autor competente. Há outras decisões a ser tomadas que necessariamente se pautam em conhecimentos além do sistema de representação, em conhecimentos sobre o que escrever e sobre as formas que pode tomar esse escrito, tema já assinalado no Capítulo 1 desta dissertação e que será reiterado aqui.

Landsmann (1995, p. 5) identifica claramente esses conhecimentos de um escritor competente, afirmando que:

\begin{abstract}
O escrever é uma atividade física e simbólica que para ser exercida precisa de um sistema - um sistema de notação convencional -, que em diferentes circunstâncias produz o escrito. Porém, o escrito não é apenas um produto circunscrito ao escrever; em comunidades com uma longa história de uso da escrita, adquiriu certa autonomia do ato individual de escrever, transformando-se em modo discursivo. A linguagem do escrito ou linguagem escrita não se refere apenas a uma peça concreta do discurso, mas a um conjunto virtual de formas de expressão que esperamos dos textos.
\end{abstract}

De fato, o ato de escrever implica o uso de um sistema de representação composto por um conjunto de princípios gerativos e regras organizadoras. Trata-se de um conjunto de convenções que definem os aspectos notacionais da escrita. Entretanto, como já se salientou no Capítulo 1, a escrita precisa ter algo para representar: um discurso em um contexto. Histórica e socialmente elaborada, a linguagem escrita contempla uma série de formas de discurso que diferem enquanto função - a que tipo de situação e de mensagem se destinam - e enquanto características (forma de linguagem e estrutura, por exemplo).

Teberosky (1997, p. 91) destaca outra possibilidade de organização desses saberes que abrangem o uso da comunicação escrita, estabelecendo três aspectos inerentes a ela:

A inventio, ou a geração de idéias, e a compositio, ou o modo de colocá-las em palavras. Ambos são apresentados freqüentemente com a denominação de 'composição'. O terceiro aspecto [...] é mais técnico; [...] scriptio: a correspondência fonográfica, a ortografia, a disposição na página, a pontuação, enfim, a caligrafia. (grifos da autora) 
“Compositio" é, aqui, um outro modo de nomear as formas de discurso. "Scriptio", por sua vez, engloba os conhecimentos notacionais, conhecimentos sobre o sistema de representação. E, nessa definição explicitada por Teberosky, inclui-se uma ação do escritor não explicitada anteriormente: a "geração de idéias” (“inventio”), o planejamento do texto, colocado em prática tanto antes quanto durante a produção. Isso quer dizer que, além do domínio sobre o escrever, o sistema de escrita e a linguagem escrita, um autor precisa conhecer e colocar em prática ações que favoreçam a comunicação que pretende estabelecer, entre as quais planejar o que ou como deseja escrever. Estudos mais recentes sobre o processo de produção textual apresentam essas ações em um novo rol de conhecimentos a ser dominados pelo escritor, os procedimentos usados no processo redacional, conforme comenta Molinari (In KAUFMAN, 2000, p. 15):

\begin{abstract}
$\mathrm{Al}$ escribir, los usuarios ponen en juego conocimientos de distinta naturaleza. Quien escribe posee conocimientos sobre el sistema de escritura o sistema de notación alfabético, es decir, acerca de sus elementos - letras y tipos de letras, signos especiales - y las reglas que rigen su relación. Pero además de las letras, quien escribe pone en acción conocimientos sobre el lenguaje escrito o el 'lenguaje que se escribe', según denominación de C. Blanche Benveniste. Es el conocimiento de un lenguaje más formal a la vez que diferente según las variedades discursivas, es decir, un lenguaje que por su uso social es esperable encontrar de manera escrita y que por ciertas características lingüísticas denota una diferenciación textual: el lenguaje de las noticias, de los cuentos, de las cartas...

Al mismo tiempo, los buenos usuarios conocen y ponen en práctica ciertos procedimientos durante el proceso de escritura. En este proceso redaccional los buenos productores prevén y evalúan constantemente qué escribir y cómo hacerlo en acciones recursivas de planificación, textualización y revisión has lograr el producto deseado. Por lo general, sus textos no surgen de primera intención; es necesario volver una y otra vez sobre ellos hasta alcanzar la mejor producción en contenido y forma. (grifos da autora) ${ }^{13}$
\end{abstract}

\footnotetext{
13 “Ao escrever, os usuários colocam em jogo conhecimentos de distinta natureza. Quem escreve possui conhecimentos sobre o sistema de escrita ou sistema de notação alfabético, quer dizer, acerca de seus elementos letras e tipos de letras, signos especiais - e as regras que regem sua relação. Mas além das letras quem escrever coloca em ação conhecimentos sobre a linguagem escrita ou a 'linguagem que se escreve', segundo denominação de C. Blanche Benveniste. E o conhecimento de uma linguagem mais formal difere-se segundo as variedades discursivas, quer dizer, uma linguagem que por seu uso social espera-se ser encontrada de maneira escrita e que, por certas características lingüísticas, resulta em uma diferenciação textual: a linguagem das notícias, dos contos, das cartas....

Ao mesmo tempo, os bons usuários conhecem e colocam em prática certos procedimentos durante o processo de escrita. Nesse processo redacional os bons produtores prevêem e avaliam constantemente o que escrever e como fazê-lo em ações recursivas de planejamento, textualização e revisão até se chegar ao produto desejado. Em geral, seus textos não surgem de primeira intenção; é necessário voltar uma ou outra vez sobre eles até alcançar a melhor produção em conteúdo e forma.” (Tradução livre - Andréa Luize)
} 
Isso significa que os conhecimentos relativos ao sistema de escrita e à linguagem escrita são evidenciados em um processo de tomada de decisões e de idas e vindas sobre o texto. $\mathrm{O}$ planejamento, a textualização, a revisão e a edição formam um conjunto de ações que o escritor realiza para ajustar seus conhecimentos à situação de comunicação em que está inserido. O que dizer no texto? Com que tipo de linguagem? Com quais expressões? Qual a pontuação mais adequada? Qual a estrutura que esse texto deve ter? Essas e outras importantes decisões são tomadas ao longo do processo redacional.

No caso dos escritores iniciantes, além desses procedimentos já colocados em jogo no processo redacional, as questões referentes ao princípio alfabético figuram com grande destaque entre as decisões a ser tomadas. Assim, por um longo período (e talvez pela vida toda), os escritores vão lidar com a necessidade de ampliar seus conhecimentos sobre os inúmeros aspectos relacionados ao ajustamento do texto.

Espera-se que um escritor seja capaz de tomar uma série de decisões durante a produção, planejando, compondo, revisando e editando seu texto com base nos conhecimentos sobre o sistema de representação (aspectos notacionais) e a linguagem escrita (aspectos discursivos).

Para a análise a ser feita nesta pesquisa, partiu-se da premissa de que as crianças não apenas são capazes de compor textos antes mesmo de dominar boa parte dos conhecimentos de um hábil escritor, mas também podem utilizar os procedimentos que observam e vivenciam em suas experiências com a produção textual. Ou seja, as crianças realizam reflexões de naturezas diversas enquanto escrevem e, sob intervenções do professor nas situações escolares ou mesmo em experiências vividas fora da escola, avançarão em seus conhecimentos sobre o sistema de representação, a linguagem escrita e igualmente sobre os procedimentos escritores. É por essa razão que as unidades nas quais se pautará a análise a seguir levam em conta esses três grandes conjuntos de saberes e suas inter-relações. Planejar, textualizar e revisar são procedimentos que não existem de maneira isolada, mas em relação direta às decisões sobre a notação e o discurso. Quando se planeja o que escrever, por exemplo, pode-se antecipar tanto o que e o como dizer, quanto as letras que utilizar para grafar cada palavra, como se verá mais adiante.

A despeito das reflexões tão integradas que o sujeito-autor pode fazer na produção escrita, o objetivo da presente pesquisa de colocar em evidência os processos e procedimentos das crianças escritoras impõe a necessidade de considerações paralelas sobre diferentes dimensões. Assim, tomar-se-á por referência duas grandes unidades de conhecimentos no 
processo redacional : aspectos discursivos e aspectos notacionais. Procurar-se-á identificar reflexões e tomadas de decisões das crianças ao longo da elaboração dos quatro textos propostos, levando-se em consideração as especificidades das circunstâncias de produção.

Este capítulo focará a primeira unidade de análise - processo redacional e aspectos discursivos - e será organizado de acordo com o seguinte quadro das categorias e subcategorias:

\section{QUADRO 3 - ORGANIZAÇÃO DO CAPÍTULO 4}

\begin{tabular}{|c|c|c|c|}
\hline $\begin{array}{l}\text { 4.2. O processo } \\
\text { redacional e os } \\
\text { aspectos discursivos: } \\
\text { a produção de listas }\end{array}$ & $\begin{array}{l} \\
\text { 4.2.3. Revisão: } \\
\text { controlando e avaliando a } \\
\text { produção } \\
\text { 4.2.4. Algumas } \\
\text { considerações }\end{array}$ & $\begin{array}{l}\text { 4.2.2.2. Breves } \\
\text { considerações sobre o } \\
\text { conteúdo das listas } \\
\text { 4.2.2.3. Reflexões sobre a } \\
\text { estrutura das listas }\end{array}$ & $\begin{array}{l}\text { a)- Relação com o } \\
\text { lugar (praia ou } \\
\text { montanha) e com a } \\
\text { temperatura (calor ou } \\
\text { frio); } \\
\text { b)- Relação com a } \\
\text { quantidade } \\
\text { viajantes; } \\
\text { c)- Relação com a } \\
\text { quantidade de dias em } \\
\text { que se permaneceria } \\
\text { no lugar; } \\
\text { d)- Relação com a } \\
\text { quantidade de objetos } \\
\text { a ser levados; } \\
\text { e)- Relação com } \\
\text { preferências ou com } \\
\text { gênero (o que é só } \\
\text { para meninas ou } \\
\text { meninos); } \\
\text { f)- Relação interna: } \\
\text { adequação entre itens } \\
\text { da própria lista. }\end{array}$ \\
\hline $\begin{array}{l}\text { 4.3. O processo } \\
\text { redacional e os } \\
\text { aspectos discursivos: } \\
\text { a produção de } \\
\text { parlendas } \\
\end{array}$ & $\begin{array}{l}\text { 4.3.1. Planejamento do } \\
\text { texto } \\
\text { 4.3.2. Textualização: } \\
\text { refletindo e compondo o } \\
\text { texto }\end{array}$ & $\begin{array}{l}\text { 4.3.2.1. Reflexões sobre a } \\
\text { estrutura das parlendas }\end{array}$ & \\
\hline
\end{tabular}




\begin{tabular}{|l|l|l|l|}
\hline & $\begin{array}{l}\text { 4.3.3. Revisão: } \\
\text { controlando e avaliando a } \\
\text { produção }\end{array}$ & & \\
\hline $\begin{array}{c}\text { 4.4. Algumas } \\
\text { considerações }\end{array}$ & & & \\
\hline
\end{tabular}

\subsection{O PROCESSO REDACIONAL E OS ASPECTOS DISCURSIVOS: ANÁLISE DA PRODUÇÃO DE LISTAS}

A análise dos aspectos discursivos e das operações efetuadas pelas crianças-escritoras revela uma diferença significativa quando se compara os processos de produção das listas e das parlendas.

As listas solicitadas tinham propósitos claramente definidos e configuravam-se como textos que deveriam ser retomados em um momento posterior, já que registrariam os itens a ser levados em uma viagem. A primeira lista, produzida no papel, deveria conter itens a ser levados na bagagem para uma viagem de três dias para uma praia, em um lugar muito quente. A segunda lista, produzida no computador, deveria reunir itens para uma viagem a uma região nas montanhas, sob baixa temperatura.

As classes de Grupo 3 e de Grupo 4, freqüentadas pelas crianças observadas, realizam, respectivamente, um acantonamento (dormir na escola) e um acampamento (em um local fora da região central de São Paulo). Essas duas situações, ainda não vivenciadas pelas crianças no momento em que a pesquisa teve início, foram utilizadas na apresentação das consignas: “imaginem que iremos acampar em uma praia/montanha onde está muito calor/frio. Ficaremos nesse lugar durante três dias. O que precisaremos levar na bagagem?”

Como se busca uma análise do processo de reflexão sobre e ao longo da produção textual, tomar-se-á como base as transcrições dos diálogos entre as crianças de cada dupla, as anotações feitas pela investigadora, as ações por ela realizadas quando solicitada pelas crianças e o resultado da produção.

Com base nesse âmbito de observação, serão apresentados os aspectos mais recorrentes na reflexão e na tomada de decisões para a elaboração das listas, sem deixar de lado alguns exemplos singulares que podem retratar a particularidade da construção de conhecimentos. 


\subsubsection{Planejamento do texto}

Tener algo para decir e ideas sobre cómo decirlo. Cualquier persona que comienza a escribir lo hace teniendo alguna idea acerca de qué va a poner. [...] Esas ideas comprometen tanto el plano del contenido (qué va a decir) como lo plano retórico (cómo lo va a decir). (CASTEDO, In KAUFMAN, 2000, p. 123, grifos da autora). ${ }^{14}$

Tomar decisões sobre o texto antes de iniciá-lo significa planejar a produção. No caso das listas propostas, poucas foram as duplas que se dedicaram a essa tarefa. As que o fizeram discutiram brevemente o conteúdo no contexto da situação apresentada, como no seguinte exemplo $^{15}$ :

Flora: Já tô com frio, só de pensar...

Daniel: Eu também! Pode ser no pólo norte ou no pólo sul essa montanha...

Flora: Então tem que levar uns quatro casacos para cada um, e casacos de lã...

Daniel: É bom... E cachecol também.

$\mathrm{L}_{1 / \mathrm{D} 3}{ }^{16}$

As crianças, nesse momento, já imbuídas da tarefa de produzir um texto, incorporam o propósito que deve guiar a organização da lista e retomam suas experiências e conhecimentos sobre o tema. Há em jogo um objetivo muito preciso, já assimilado pelos pequenos escritores: fazer a lista de bagagem para uma viagem de três dias frios à montanha. Desde o início da elaboração da lista, as crianças assumem a tarefa de escrever e se preocupam com questões pertinentes ao contexto em que foram inseridas e, da mesma forma, ao tipo de texto que devem escrever.

\footnotetext{
14 “Ter algo para dizer e idéias sobre como dizê-lo. Qualquer pessoa que começa a escrever o faz tendo alguma idéia do que vai colocar. [...] Essas idéias comprometem tanto o plano do conteúdo (o que se vai dizer) quanto o plano retórico (como se vai dizer).” (Tradução livre - Andréa Luize)

${ }^{15}$ A partir deste item serão apresentadas como exemplos várias transcrições de trechos dos diálogos das crianças da dupla. Para facilitar a visualização desses trechos, as transcrições aparecerão sempre dentro do quadro pontilhado e com igual formatação. As informações dentro de parênteses referem-se a ações realizadas pelas crianças, anotadas por mim, ou observações que faço a fim de favorecer a compreensão da situação. As palavras foram grafadas conforme ditas pelas crianças, garantindo a reprodução fiel mesmo no caso de incorreções.

${ }^{16}$ Como identificação dos textos e das duplas, será também utilizada a seguinte referência: L1, para a lista de bagagem de viagem para a praia, produzida no papel; L2 para a lista de bagagem para a montanha, produzida no computador e $\mathrm{D}$, seguido de um número, refere-se à dupla em questão, conforme apresentado no capítulo 3.
} 
Como faz a dupla acima, antes mesmo de começar um texto, pode-se refletir e tomar certas decisões que favoreçam a produção. Nessa etapa do processo, acionam conhecimentos sobre o tipo de texto em jogo e sua linguagem (“quatro casacos”), sobre as circunstâncias descritas (viagem, montanha, frio), sobre os próprios conteúdos (não basta qualquer casaco, mas “casacos de lã”) e sobre experiências e informações que possuem (tomam as regiões polares como uma referência de frio intenso, por exemplo).

A circunstância clara e explícita da tarefa de escrever também estimula o envolvimento das crianças. Não se observou qualquer tipo de reação contrária à escrita do texto. Ao invés disso, foi recorrente o fato das crianças já se colocarem como integrantes dessa viagem e até comentarem sensações provocadas pela própria situação, como se pode ver na seguinte fala: “já estou com frio, só de pensar”. Assim como fez a dupla citada, tão logo puderam começar a lista, foram decidindo o que escrever e iniciando a grafia dos itens e quantidades. A disponibilidade com a qual assumem a tarefa é fruto não apenas da clareza do contexto de produção, mas também das experiências que vivenciam, rotineiramente, na sala de aula, tendo que escrever a partir de um propósito social.

O exemplo acima ilustra as reflexões sobre o texto antes de darem início à sua produção. Ocorrências ou diálogos dessa natureza aconteceram antes da digitação do texto em questão. Porém, sabe-se que um escritor, na maior parte das vezes, não toma todas as decisões antes de escrever um texto. Ao longo de sua produção, planeja e replaneja o que dizer e como fazê-lo, ações observadas também entre as duplas de crianças aqui analisadas.

\subsubsection{Textualização: refletindo e compondo o texto}

Do ponto de vista didático, o trabalho em parceria e a divisão de papéis, com tarefas específicas sobre as quais se centrar, favorece o processo de elaboração textual por parte dos escritores-aprendizes. A importância das parcerias já mereceu a atenção de alguns pesquisadores, entre os quais Teberosky e Ribera (In TEBEROSKY; GALLART, 2004) e Molinari e Castedo (In KAUFMAN, 2000). Na perspectiva dessas investigações, entende-se que, se por um lado, é possível que cada criança exerça um papel diferenciado na dupla, concentrando-se em problemas diferentes da produção (quem dita encarrega-se do discurso, da composição do texto, de sua linguagem; quem escreve encarrega-se de decidir com que letras grafar o que lhe é ditado, reflete 
acerca da segmentação entre as palavras, da organização do texto sobre o suporte...), por outro lado, a cooperação, a confrontação de idéias e o intercâmbio de conhecimentos podem também ter lugar nesse tipo de situação.

Foi justamente desse modo que aspectos referentes ao conteúdo e à estrutura do texto apareceram nas reflexões das crianças e subsidiaram as tomadas de decisão para a composição do texto. Pensar e decidir sobre o que dizer e sobre a estrutura textual geraram inúmeros intercâmbios e ricos momentos de discussão e serão, a partir daqui, analisados separadamente.

\subsubsection{Reflexões sobre o conteúdo das listas}

Ao longo dos diferentes processos de produção das listas, as discussões sobre o conteúdo - o que levar na bagagem e em que quantidade - aconteceram de forma intensa e sistemática. Nessas ocasiões, a interação entre as crianças tendia a se ampliar e o intercâmbio entre tarefas se tornava evidente: não só quem tinha como papel ditar o texto tomava decisões sobre seu conteúdo, mas também os supostos escribas participavam parte dessas decisões. Efetivamente, isso ocorreu de formas diferenciadas a depender não apenas da parceria, mas também da decisão a ser tomada. Por vezes, o escriba sugeria um conteúdo, embora a decisão final ficasse a cargo do ditante. Também se observou momentos em que o próprio escriba tomava para si a tarefa de decidir o que escrever e, tão logo anunciava o item ao colega, este já começava a grafá-lo. Muito mais comum, no entanto, foram as situações em que as crianças decidiram juntas o conteúdo da lista, a partir da sugestão do ditante ou do escriba, como se vê no exemplo abaixo:

Camila: Calcinhas tem que levar.

Jhoão: O quê?...

Camila: Calcinhas pra mim e pra você cueca.

Jhoão: Tá.

L2/D5 - Camila: escriba/ Jhoão: ditante

As parcerias realmente alternaram os papéis quando estava em jogo tomar decisões sobre o conteúdo, podendo concordar ou discordar do colega, considerando critérios variados, 
entre os quais a necessidade de que os itens da lista estivessem de acordo com os propósitos da composição dos textos. Como aponta Castedo (In KAUFMAN, 2000, p. 122),

Cuando estos propósitos están claros para los niños [...] pueden juzgar con mayor adecuación sobre la pertinencia de lo que se escribe, seleccionar con más precisión la información que se incluye y que se descarta [...].

Pero además, existe otro elemento que interviene en la toma de estas decisiones: el destinatario, para quién se escribe. ${ }^{17}$

Na atuação com seus parceiros, boa parte das crianças observadas mostrou-se capaz de refletir e decidir tomar decisões sobre o que escrever, levando em conta todas as características da situação que lhes fora apresentada (calor/praia, frio/montanha, quantidade de viajantes e de dias), demonstrando grande preocupação em colocar na listagem itens que tivessem relação com o propósito em jogo. Porém, as parcerias adotaram critérios diferenciados ao ter que optar por um determinado item, entre os quais a quantidade de viajantes e de dias de viagem, a relação com características do ambiente e temperatura. Pela diversidade de critérios que norteou as escolhas de itens para a composição dos textos, fez-se a opção de apresentá-los um a um, ilustrados por exemplos extraídos dos diálogos entre a dupla de autores. Vale salientar que o uso do papel ou do computador não pareceu ter influência nessas discussões ocorridas em ambas as situações de produção.

a)- Relação com o lugar (praia ou montanha) e com a temperatura (calor ou frio):

Bruno: Agora, tênis.

Antonio: Tá calor, na praia, pra quê tênis?

Bruno: Tá, sandália, então.

Aqui, foram acionados conhecimentos das crianças sobre características dos ambientes; certamente suas experiências em praias contribuíram para determinadas decisões, assim como

\footnotetext{
17 “Quando esses propósitos estão claros para as crianças [...] podem julgar com maior adequação sobre a pertinência do que se escreve, selecionar com mais precisão a informação que se inclui e que se descarta [...]

Mas, além disso, existe outro elemento que intervém nessas decisões: o destinatário, para quem se escreve.”

(Tradução livre - Andréa Luize)
} 
observar ou ter colaborado na arrumação de bagagens e nas situações vivenciadas no próprio local. Nesse sentido, vale citar outros dois exemplos em que itens são descartados: uma dupla optou por não inserir em sua lista "guarda-sol”, visto que uma das crianças destacou o fato de que, em algumas praias, esse objeto já existe, colocado por hotéis, pousadas ou mesmo quiosques da região; outra dupla reduziu a quantidade de toalhas a ser levadas para a praia, pois elas "secam rapidamente” por causa do calor e podem ser reutilizadas nos dias posteriores.

b)- Relação com a quantidade de viajantes:

A quantidade de viajantes também foi foco de reflexão em algumas duplas, conforme atesta o seguinte exemplo:

Daniel: Agora, maiô, então... Três maiôs...

Flora: Não. Não pode. Tem que ser mais... (põe três dedos em cada mão e mostra para o colega). Põe mais três, Daniel.

Daniel: (coloca mais três dedos para ajudar na contagem e conta) Um, dois, três, quatro, cinco, seis sete, oito nove.

Flora: Então tem que ser nove pra todo mundo, porque sou eu, você e ela (refere-se a mim) e são três dias. Usa um maiô em cada dia.

Daniel: Tá.

L1/D2

Atendendo à solicitação feita, as crianças, nesse caso, sentiram que não bastava enumerar os itens, era preciso também estabelecer as quantidades necessárias. Em algumas duplas, a opção foi colocar quantidades para uma lista individual. Para outras, a alternativa, como acima, foi uma listagem coletiva, daí a importância de se precisar quanto levar de cada item. Cabe ressaltar que essa reflexão exigia, em alguns momentos, uma contagem de caráter preciso (também exemplificada acima), ilustrando, novamente, o significado real atribuído a essa proposta de escrita.

c)- Relação com a quantidade de dias em que se permaneceria no lugar

Outra preocupação das crianças foi relacionar a quantidade de itens à quantidade de dias de duração da viagem, como mostra o exemplo abaixo: 
Clara: Quantas bermudas? ...

Pedro H.: Não são três dias? Então três. Uma pra cada dia.

Clara: Tá

(Pedro H. escreve o número 3).

L1/D8

Definir o que dizer está estreitamente associado às circunstâncias explícitas que envolvem o texto. Saber que permaneceriam três dias no local foi outro aspecto inserido nas discussões e que precisava ser considerado pelas crianças.

Em algumas duplas, a relação entre a quantidade de dias de permanência no local mesclava-se, ao longo da discussão, com a quantidade de viajantes, como se pôde verificar no exemplo que ilustra o item b e também no que se segue:

Bruno: Tá! Agora apaga esse seis e põe um oito.

Antonio: Que seis?

Bruno: Da calça. Apaga e põe oito.

Antonio: Por que?

Bruno: Porque tem que ser mais calças. (diz e vai apertando a seta do teclado até voltar ao seis)

Antonio: Pára! Pára! Chega, Bruno! (grita com o amigo) Pára de mexer, tem que deixar assim.

Bruno: Seis é pouco!

Antonio: Eu acho que seis tá bom.

Bruno: Tem que ser mais. Tem que ser oito. Quantos dias vamos ficar lá?

Antonio: Três.

Bruno: E vão eu, ele e você. Três pessoas. Por isso. Seis calças não dá! Usa uma num dia (põe um dedo), outra no outro dia (põe dois dedos) e outra no outro (põe três dedos). Três pra cada um. São... que é três pra mim (põe três dedos), três pra ela (põe outros três) e três pra você (põe mais três). Isso dá... nove.

Nove calças. Eu achei que era oito, mas é nove, viu?

Antonio: Tá. Nove calças.

Como se nota, nem sempre as discussões se estabeleceram de maneira harmoniosa. Em alguns casos, interferir na tarefa do colega (como ocorre quando Bruno tenta apagar o número já digitado pelo amigo) gerava pequenas tensões, mas não suficientes para impedir a troca de opiniões. Na maior parte das vezes, as próprias crianças conseguiam resolver esses impasses. É preciso considerar que esses escritores vivem na tarefa de produção inúmeros desafios, entre os 
quais se coloca a própria co-autoria. Trata-se de chegar a um consenso com o colega, pois há um único texto a ser composto. Embora se reconheça a importância do intercâmbio resultante das discussões promovidas, dividir tarefas e decisões também representa um conteúdo de aprendizagem para esses escritores iniciantes.

d)- Relação com a quantidade de objetos a ser levados:

As experiências das crianças como viajantes interferem todo o tempo nas decisões que tomam sobre o que levar nas bagagens. Atentar para as peculiaridades dos objetos é um dos aspectos ressaltados nas falas das crianças e intervém na escolha de um ou outro item ou mesmo em suas respectivas quantidades.

A dupla 2 ocupou-se em decidir a quantidade de botas a ser levadas. O problema em questão estava em favorecer a compreensão da lista com base no critério de quantificação (os calçados ou os pares de calçados):

Daniel: Isso. Agora botas?... Quatro botas.

Flora: É. Uma, né? Uma bota pra cada um. Não quatro.

Daniel: Uma, não, né? Uma só, não. Duas...

Flora: Duas, não... Um par de botas, né?

Daniel: Então. Tem que ser quatro botas. Pra fazer duas mais duas, mais duas, mais duas. Tem que ser quatro botas

Flora: Não... É que vai colocar no pé, e você sabe, né? Tem que colocar no pé. Então é um par.

Objetos que podem ser usados coletivamente e outros que, ao contrário, precisam ser considerados de modo individual também centraram discussões por parte das crianças, como acontece com a dupla 8:

Clara: Uma pasta de denti. Põe uma

Pedro H. Não, põe três.

Clara: A gente pode usar juntos. A pasta dura diiiias, dura bastante.

Pedro H.: Tá (digita 1) 
Pedro H.: Quantas escovas de cabelo?

Clara: Uma.

Pedro H.: Uma pra cada, né? Porque cada um tem que usar a sua própria escova, né? (diz enquanto procura e digita 1)

e)- Relação com preferências ou com gênero (o que é só para meninas ou meninos):

Alguns dos itens mereceram atenção especial por parte das duplas, muitas vezes pela necessidade de considerarem peculiaridades das meninas ou meninos. Aqui, por exemplo, entra a necessidade de se levar sunga e biquíni ou mesmo cueca e calcinha. Preferências também são observadas: quem não usa sunga, quem passa todo o dia usando biquíni, apenas para citar alguns casos. As soluções encontradas para esses impasses também diferem entre si, pois em relação a alguns itens, optaram por escrever ambos (exemplo: “shorts ou bermuda”) e, em relação a outros, a escolha foi escrever apenas um deles, de modo que pudesse ser compreendido pelos dois autores, como se vê abaixo:

Pedro H.: E agora?...

Clara: Falta biquíni.

Pedro H.: Eu não uso isso! Uso sunga.

Clara: Então escreve os dois, de novo (diz de novo, referindo-se à escrita de "shorts ou bermudas").

Pedro H.: Ah, não. Eu tô cansado.

Clara: Ah, então põe sunga e eu sei que tem que ser biquíni também, pra mim.

Preferências ou necessidades individuais também influenciam nas decisões sobre o conteúdo:

Beatriz: Bóia.

Luiz: Não precisa. Eu não uso.

Beatriz: Eu perciso. O meu binquedo favorito, lá do Hopi Hari é a montanha russa e percisa de bóia.

Luiz: Mas eu não preciso disso. Eu sei nadar lá no fundo.

Beatriz: Mas eu vou levar, senão eu nem vou nessa viagem! 
Luiz: Então, põe só pra você. Você precisa? (pergunta para mim)

$\mathrm{E}^{18}$ : Eu não preciso, mas a Beatriz precisa.

Beatriz: É. Uma bóia. Uma bóia de braço... Não, que tal uma pranchinha? Eu ganhei de Papai Noel. Eu

tenho uma pranchinha...

f)- Relação interna: adequação entre itens da própria lista:

Um dos desafios para as crianças era a necessidade de compor, de fato, uma lista de bagagem, lembrando de anotar tudo o que seria importante para uma viagem à praia ou a uma montanha. Dentre as tantas reflexões que realizam, também se notou uma preocupação com a relação interna dos conteúdos que integram a lista. Por exemplo, se "calça” foi um dos itens, obviamente é preciso escrever algo para completar uma vestimenta: “camisa” ou "blusa”. Nesse sentido, o seguinte exemplo é ilustrativo:

Pedro H.: E agora?... Já sei. Se já foi shorts ou bermuda, falta camiseta.

Clara: Tá bom. Camiseta. Pode escrever.

4.2.2.2. Breves considerações sobre o conteúdo das listas

Todas as duplas, sem qualquer exceção, revelaram momentos de preocupação com o conteúdo e com a sua pertinência em relação ao propósito do texto que compunham. Mas, por razões diversas, nem todas as parcerias tinham essa questão como fonte sistemática de reflexão.

Para algumas crianças, adequar conteúdo e propósito era algo que as preocupava de maneira recorrente. Esse foi o caso das duplas 2 e 8, citadas em muitos dos exemplos, também por realizarem essa tarefa a partir de critérios diversos: preocupação com a quantidade de viajantes, com a quantidade de dias, com as características do local etc. Outras duplas, entretanto, centraram sua reflexão intensamente em como grafar as palavras e nem sempre o conteúdo escrito tinha real pertinência com o objetivo da lista. Esse foi o caso da dupla 7. Na seleção de alguns itens, notou-se uma preocupação com o lugar/temperatura (levar boné para a praia ou

\footnotetext{
${ }^{18}$ As falas atribuídas a E indicam “entrevistadora” e explicitam suas participações nos diálogos.
} 
muitos casacos para a montanha) ou com preferências (levar uma determinada colcha para dormir no carro durante a viagem). Porém, muito mais freqüente na produção dessa dupla foi a seleção de itens pela facilidade na grafia das palavras ou mesmo porque a criança ditante as conhecia de memória, baseada nas hipóteses que tinha sobre a escrita. Foi por essa razão que optaram pela escrita de "peixe”, "banana” e "gato” na lista de viagem para a praia. Essas questões serão abordadas mais adiante, no capítulo em que se discutirá as reflexões sobre os aspectos notacionais.

\subsubsection{Reflexões sobre a estrutura das listas}

No processo de elaboração das listas, outro ponto de reflexão foi a estrutura do texto, conforme citado no tópico 4.2. As crianças, enquanto usuárias de diferentes tipos de textos, não são capazes somente de compreender suas funções, mas podem observar a forma como se organizam no papel, aspecto que também os diferencia e identifica. As listas atendem a propósitos variados de seus escritores, mas caracterizam-se pela enumeração de itens, em geral grafados um sob o outro, um em cada linha. Esse aspecto gerou discussões entre as crianças, especialmente na produção no computador.

Na primeira lista elaborada no papel, as duplas demonstraram conhecer a necessidade de mudança de linha ao escrever cada item e o fizeram de maneira automática; geralmente, o próprio escriba tomava a decisão sobre onde iniciar a palavra ditada pelo colega, já posicionando o lápis na margem esquerda do papel.

Na lista produzida no computador, contudo, a própria configuração do WORD programa utilizado para a produção dos textos - impedia uma mudança automática de linha: era necessário apertar uma tecla para que uma nova linha pudesse ser iniciada. Tal diferença em relação ao uso do papel trouxe para às crianças-escritoras o desafio de resolver esse impasse, o que se explicitou em alguns diálogos, como no seguinte exemplo:

Daniel: E agora?

Flora: Agora... Tem que levar quatro gorros de lã.

Daniel: Isso. Pode ser.

Flora: Quatro (digita o 4 na mesma linha e sem separação em relação à grafia da palavra casaco que acabaram de escrever)

Daniel: Não, não. Tem que ser aqui embaixo, é uma lista! (aponta embaixo do 4 de casacos, digitado no 
início da primeira linha)

Flora: Como faz para colocar um tracinho para separar? (pergunta dirigindo-se a mim)

Daniel: Como faz para mudar de linha? (os dois perguntam juntos. Flora quer o tracinho e Daniel a

mudança de linha. Antes que eu responda, Daniel e Flora repetem a pergunta feita por Daniel, agora, juntos)

Flora e Daniel: Como faz para mudar de linha?

E: (Mostro a tecla "enter", mas sem apertá-la).

Flora: (apaga o 4, usando a tecla "backspace” que acabou de descobrir e tecla na tecla "enter" e refaz o 4)

$\mathrm{L} 2 / \mathrm{D} 2$

O que se verifica nesse diálogo é que algo já reconhecido e utilizado por esses escritores - a mudança de linha na organização da lista - torna-se um objeto de reflexão em virtude da mudança no suporte da produção. Ao escrever no computador, mudar de linha deixa de ser uma ação automática e passa a ser uma preocupação explícita por parte desses aprendizes, o que reitera o tanto que essa característica do texto em elaboração já foi apropriada por eles e é vista como essencial na tarefa de escrita em jogo. Essa apropriação provavelmente é fruto de intervenções pedagógicas. A familiaridade que possuem com as listas no cotidiano escolar é grande e favorece reflexões dessa natureza.

Outras duplas realizaram semelhante reflexão, mas tomaram decisões diferentes a fim de marcar a enumeração: o uso de hífens ou apenas vários espaçamentos, resultando em produções como esta:

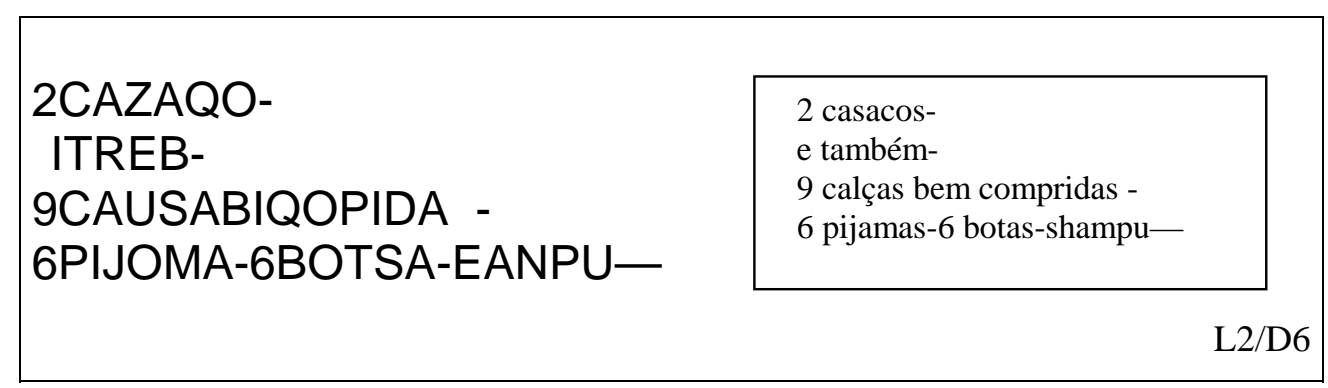

Em algumas das duplas, explicitar a necessidade de separar os objetos listados era algo feito somente por uma das crianças, que chamava a atenção do colega. Pôde-se verificar, por vezes, o escriba dando continuidade à escrita do texto na mesma linha, de maneira aglutinada à grafia do item anterior. Ao observar a configuração da lista no monitor, o ditante acabava interferindo na tarefa do amigo, sugerindo a separação. Nesse caso, e também como se discutirá 
posteriormente em relação aos aspectos notacionais, a escrita no computador favorece o acompanhamento do texto em composição por parte de ambas as crianças: escriba e ditante vêem o texto sendo elaborado à sua frente, ao contrário do que ocorre quando se escreve no papel, quando apenas o escriba pode acompanhar bem de perto cada passo de sua produção.

Interessante ressaltar que muitas das duplas que discutiram e organizaram as listas de modo a compor uma enumeração dos itens eleitos - separando-os de algum modo - ainda não se ocupavam em segmentar as palavras de modo convencional (aspecto que será tematizado no próximo capítulo). Essa regra do nosso sistema de escrita ainda não foi observada nas produções de muitas das crianças que participaram da pesquisa. Porém, essas mesmas crianças conseguiram marcar a separação dos itens da bagagem corretamente, compondo listas similares às organizadas por escritores experientes.

À mesma conclusão se pode chegar quando está em foco o uso da linguagem típica de listas com essa função (registrar para apoio da memória): uso de substantivos comuns, nomeando os itens. As duplas, quase em sua totalidade, escreveram a lista grafando a palavra correspondente ao item e sua respectiva quantidade, aspecto realmente peculiar a esse tipo de texto.

Ao longo das produções, a necessidade de controle sobre o texto também foi discutida por algumas crianças. Realizar tentativas de reler o texto ou solicitar a ajuda da investigadora para fazê-lo foram iniciativas espontâneas e, por esse motivo, serão mais detalhadamente apresentadas no item que se segue.

\subsubsection{Revisão: controlando e avaliando a produção}

Revisar o texto escrito é outra tarefa tipicamente realizada pelos escritores. Em geral, trata-se de avaliar a produção em relação a seu propósito e destinatário, considerando peculiaridades do tipo de texto em questão e aspectos mais gerais em relação à língua. Como destaca Rocha (In ROCHA; VAL, 2003, p. 73):

quando explicitadas as condições de produção, a revisão textual contribui para que a criança, desde muito cedo, (re)elabore concepções acerca da estrutura textual considerando aspectos relativos ao nível de informatividade do texto, à ortografia, à caligrafia, à concordância, entre outros. [...] A revisão é entendida [...] como um procedimento que permite não apenas ver melhor mas, também, ver de outra perspectiva [...] visando ao sucesso da interlocução. 
Um escritor experiente é capaz de realizar ações recursivas de revisão durante a produção do seu texto, relendo-o a cada etapa, corrigindo-o, fazendo inserções, substituições ou até extraindo aspectos que julgue necessários. A tarefa de revisar exige que o escritor modifique seu papel perante a produção e assuma a tarefa de leitor crítico de sua própria escrita.

É de se supor que o desafio de revisar seja grande para as crianças-escritoras, que muitas vezes sequer dominam o sistema alfabético, o que dificulta a retomada do texto. Como destaca Molinari (In KAUFMAN, 2000, P. 23):

Dada la edad de los niños, ésta es una tarea que recién se inicia. También hay que valorar sus resultados considerando esta condición. Es un logro que un niño comience a mirar nuevamente su escrito una vez terminado. Que además intente alguna transformación, resulta una verdadera adquisición. ${ }^{19}$

De fato, o que se pôde averiguar nos processos de produção das listas, aqui analisados, foram situações assistemáticas nas quais as crianças demonstraram a intenção de revisar o texto que compunham, muito provavelmente tomando como referência as observações feitas junto a escritores adultos. Em sala de aula, freqüentes são as situações em que devem ditar textos para a professora, que, como escritora competente, atua explicitamente revisando essas produções, seja para ter um controle sobre as mesmas (o que foi escrito e o que ainda resta escrever), seja para de fato aperfeiçoá-las.

Como são escritoras ainda pouco experientes, a intenção de controlar o texto foi algo mais perceptível entre as crianças do que propriamente as ações com o intuito de aperfeiçoá-lo. No que se refere aos aspectos discursivos, verificar o conteúdo foi a preocupação que mais gerou a necessidade de retomada do texto. Boa parte das crianças, ao afirmar o desejo de rever o que havia escrito, solicitava ajuda à investigadora. Outras, ao contrário, procuravam realizar a tarefa de acordo com suas possibilidades, como ilustra o exemplo:

\footnotetext{
19 "Dada a idade das crianças, esta é uma tarefa que acaba de se iniciar. Também é preciso se avaliar seus resultados considerando esta condição. É um êxito que uma criança comece a olhar novamente seu texto depois de terminado. Que também tente alguma transformação, resulta uma verdadeira aquisição.” (Tradução livre - Andréa Luize)
} 
escrito sunga. Olha, termina com A. Não é sunga que a gente escreveu aqui? (diz dirigindo-se a mim)

E: Isso. Aqui, vocês escreveram sunga.

Bruno: Então acabou.

Casos como os mencionados acima foram os mais comuns. Neles, a retomada do texto tinha como meta verificar o que já havia sido escrito para se decidir o que restava escrever ou mesmo buscar quantidades antes atribuídas (se levaram 6 camisetas, queriam retomar essa quantidade para levar igual número de bermudas, por exemplo).

Outra preocupação das crianças foi com a própria legibilidade do texto, denotando cuidados estéticos com o traçado da letra ou com o uso da borracha. Esse foi o caso da dupla 1, que se ocupou justamente da necessidade de uma organização no papel para tornar o texto mais legível:

Giulia: (risca o TO da palavra protetor com o próprio lápis ao invés de apagar)

Guilherme: Nããão! Não é pra riscar. Fica feio. É para apagar... Deixa que eu apago... (pega a folha e apaga o TO)

Giulia: Pode só riscar, que chato!

Guilherme: Como a pessoa vai poder entender?

Giulia: Que pessoa???

Guilherme: A gente mesmo depois. Como vai ler?

Giulia: Ah, tá!

$\mathrm{L} 1 / \mathrm{D} 1$

Embora não tomassem a revisão como uma ação sistemática do escritor e, na maior parte das vezes, demandassem o apoio da entrevistadora para a leitura, as crianças pareciam reconhecer e validar o ato de ler como forma de exercer um controle sobre a produção. É certo que ainda estão longe de revisar seus textos em todos os seus detalhes, porém, já identificam esse procedimento como parte importante da tarefa de escrita e, mais ainda, recorrem a ele na tentativa de solucionar problemas, nesses casos atrelados ao conteúdo das listas.

Cabe salientar, por fim, que as tentativas de retomada do texto foram mais constantes na produção da lista no computador, assim como foi maior a participação dos ditantes na realização dessa tarefa. O computador traz algumas vantagens quando do acompanhamento da composição do texto pelos autores (ditante e escriba), pois, conforme já foi dito, a presença do monitor à frente de ambos permite igual visualização. Além disso, no computador, o texto não está 
comprometido pelo traçado individual das letras que, nesse caso, são facilmente reconhecidas tanto por quem digita quanto por quem dita.

\subsubsection{Algumas considerações}

A análise apresentada até esse ponto permite algumas considerações de caráter conclusivo. As crianças observadas atuaram efetivamente como escritoras, colocando em jogo ações necessárias e relevantes para qualquer iniciativa de escrita. Com raras exceções, os conteúdos das listas ativeram-se ao seu propósito, evidenciando a preocupação dos autores em inserir itens que, de fato, seriam importantes em cada uma das viagens. Do mesmo modo, consideraram em suas produções características da linguagem e estrutura do texto em questão. Ainda que muitas das listas em versão finalizada não apresentem as palavras grafadas convencionalmente, as crianças vivenciaram uma situação real de produção e refletiram sobre aspectos inerentes ao desafio proposto. Mesmo pequenas e pouco experientes como escritoras, mostraram-se capazes de discutir e tomar decisões variadas sobre a composição de um texto, ao qual puderam atribuir sentido e significado. Pareceram compreender a escrita em sua função de interlocução e também de apoio à memória e, sem qualquer entrave, dispuseram-se a produzir textos escritos.

A análise dos dados continuará, no item seguinte, apontando aspectos referentes à produção das parlendas, ainda evidenciando o caráter redacional e discursivo do processo de elaboração textual.

\subsection{O PROCESSO REDACIONAL E OS ASPECTOS DISCURSIVOS: A PRODUÇÃO DE PARLENDAS}

As parlendas são textos conhecidos pelas crianças da Escola da Vila desde a série inicial da Educação Infantil. Primeiramente apresentadas de forma oral, respeitando suas origens, e em pouco tempo memorizadas pelas crianças via repetição, esses textos também favorecem situações de leitura. Por dominarem o seu conteúdo, as crianças pequenas são desafiadas a identificar determinadas parlendas escritas em cartazes. Devem buscar índices, pistas que o texto escrito 
pode oferecer. Da mesma maneira, têm acesso a esses materiais para ler as parlendas que apreciam.

Conforme avançam na escolaridade, as parlendas passam a ser utilizadas com diferentes funções: originam brincadeiras de roda, organizam brincadeiras de pular corda e favorecem sorteios, realizados a partir de suas récitas. Esporadicamente, tornam-se material não apenas de leitura, mas também de escrita para os aprendizes em atividades pedagógicas, promovendo desafios de interpretação e produção (como pensar a relação entre o conteúdo conhecido e as marcas no papel). A situação da pesquisa foi, portanto, uma atividade com sentido, levando-se em conta o rol do que é usualmente trabalhado em sala de aula.

Nesta pesquisa, busca-se identificar reflexões que as crianças são capazes de realizar ao produzir um texto que dominam de memória, diferentemente do que ocorre quando elaboram um texto cujo conteúdo precisam decidir em função de destinatários e propósitos específicos. Os mesmos critérios utilizados na análise das listas serão considerados aqui.

\subsubsection{Planejamento do texto}

Ao contrário do que se viu em relação às listas, todas as duplas anteciparam espontaneamente o conteúdo dessas novas produções, tanto ao escreverem no papel quanto no computador, recitando a parlenda solicitada antes de iniciar sua escrita. Não estava em jogo decidir o que escrever, apenas retomar o conteúdo que era de domínio de ambos os autores escriba e ditante.

E: (apresento a consigna para a produção)

Pedro: Eu conheço essa. Eu sei essa palenda.

João: Eu também,

Pedro: Vamo falar ela?

João e Pedro: Um, dois, feijão com arroz. Três, quatro, feijão no prato (e assim seguem recitando a parlenda que conhecem na mesma versão).

Pedro: Agora começa a esquever!

\footnotetext{
${ }^{20} \mathrm{P} 1$ refere-se à parlenda “Um, dois, feijão com arroz...”, produzida no papel e P2 refere-se à parlenda “A galinha do vizinho...”, elaborada no computador.
} 
Em alguns casos, as crianças conheciam versões diferentes da parlenda e optavam por uma delas, já no momento de planejar o texto, exceção somente a uma das duplas que tomou essa decisão durante a produção.

No caso das parlendas, ter de memória o conteúdo do texto fez com que as crianças prescindissem da necessidade de refletir e tomar decisões sobre o que dizer. Além disso, considerando a natureza da atividade sem propósitos e destinatários estabelecidos, pode-se afirmar que esses sujeitos-escritores puderam dispensar decisões centradas no que escrever.

\subsubsection{Textualização: refletindo e compondo o texto}

Um diferencial na produção das parlendas era o fato de que ambos os autores dominavam o conteúdo, conforme já se destacou. A tarefa de ditar, por essa razão, perdeu seu sentido em determinados momentos. Por vezes, o próprio escriba seguia adiante na elaboração do texto, sem aguardar o ditado a ser feito pelo colega. Também foi possível identificar uma mudança na atuação de alguns dos ditantes, que passaram a falar não mais trechos ou palavras, mas as letras, isoladamente. Ambos os aspectos estão ilustrados no exemplo:

Giulia: Eu coloco o um, o dois e feijão (diz enquanto grafa os algarismos 1 e 2)

Guilherme: (olha a notação feita) E agora o F. E depois o ÃO.

P1/D1/ Giulia: escriba e Guilherme: ditante

Em algumas duplas, verificou-se ainda um distanciamento por parte dos ditantes em relação à tarefa, sobretudo na escrita da parlenda feita no papel. Crianças que, na produção das listas, tinham uma atuação atenta e constante, acabaram, aqui, tendo um papel secundário, muito mais acompanhando a elaboração do texto do que participando dela. Esse foi o caso de Jhoão, que parece não ter mais o mesmo compromisso em relação à produção:

Camila: (segue escrevendo) Um, dois, fei-jão-coa-rroz (silaba baixinho enquanto escreve. Conclui este verso e continua a grafar, mudando de linha) Três, quatro, fei-jão-nu-pra-to (silaba baixinho e segue escrevendo)

Jhoão: Você já acabou? (diz ele observando o mural da classe)

Camila: Ainda não. E você não vai ditar?

Jhoão: Você já sabe... Continua que depois eu olho o texto. 
Camila: (continua a escrever iniciando o próximo verso e mudando de linha novamente)

Considerando o exemplo, o que se conclui é que, até mesmo para escritores pouco experientes, ditar perde em significado quando se trata de algo dominado por ambos os autores. Corre-se o risco de que esse importante papel frente à produção - o de ditante - se desconfigure por se tornar um ditado de letras e não do conteúdo do texto propriamente.

Um dado relativo ao conteúdo da parlenda “A galinha do vizinho”, elaborada no computador, merece especial atenção. Há nessa parlenda, conforme o Quadro 4 (p. 102), uma repetição da expressão "bota”. A partir do terceiro verso ("bota 1") foi recorrente que as crianças, ainda que o dissessem, omitissem a grafia da palavra que se repete, resultando na escrita somente da seqüência numérica que a acompanha, como mostra o seguinte diálogo:

Angela: bota um, bota dois...

Vitor: É aqui? (indica a mesma linha)

Angela: É

Vitor: (digita 12 )

Angela: bota um, bota dois, bota três, bota quatro, bota cinco, bota seis, bota sete, bota oito, bota nove, bota dez

Vitor: (conforme ela fala cada número ele o digita usando a parte direita do teclado. Ele já fica com o dedo sobre o próximo número no teclado, mas espera Angela ditar. Omitem a grafia da palavra bota e não observam essa questão ainda que se mantenham olhando o monitor.)

Angela: Agora o dez. O um e o zero.

A produção final dessa mesma dupla ilustra também a omissão:

AHIAOIVZOUOOAMTIO12345678910
AITOR
ANGELA

Na tentativa de explicar essa ocorrência, é possível considerar algumas hipóteses, não exclusivas nem definitivas. Pode ser que a repetição excessiva da palavra - aparece onze vezes na parlenda - seja, por si só, a razão da omissão. As crianças observadas estão acostumadas, em sua 
vivência escolar, a ditar para a professora textos de comunicação informal, narrativas literárias e textos informativos, revisados coletivamente. Nesses contextos, a repetição constante de palavras tende a ser desqualificada. Por exemplo, ao elaborarem uma legenda informativa sobre um animal pesquisado, é comum que, em primeira versão, usem somente o nome do animal ao se referir a ele: “O urso polar é mamífero. O urso polar é um bom caçador...”. Buscar expressões ou termos que o substituam costuma ser discutido em situação de revisão: “O urso polar é mamífero. Ele é um bom caçador...”. A repetição excessiva de um mesmo termo em outros textos também costuma ser tematizada em sala de aula. Poder-se-ia supor que as crianças, nas produções experimentais, retomassem implicitamente essas experiências e desconsiderassem a necessidade de escrever tantas vezes uma mesma palavra.

Outra justificativa pode envolver o domínio oral sobre o texto, dispensando a repetição. Ainda que não grafem, as crianças sabem que os números ali representados acompanham a expressão "bota”, tanto que, sem exceção, as sete duplas que digitaram somente os algarismos nesse trecho o fizeram enquanto recitavam "bota um, bota dois, bota três", e assim seguiram até o final dessa produção. Nesse caso, a dimensão social da escrita (a escrita como meio de explicitar uma idéia para o outro), não evidenciada na proposta de produção, submete-se à lógica de "uma escrita para si mesma”, uma dimensão mais próxima do discurso interior, em que não há necessidade de registrar o já conhecido.

Uma terceira possibilidade de interpretação para tal ocorrência vincula-se ao que já foi destacado por Ferreiro e Teberosky (1985). Em um determinado momento da conceitualização do sistema de escrita, as crianças crêem que a leitura é uma interpretação de elementos ou inscrições indiciais registrados no papel, ou seja, que não há correspondência entre o que está escrito e o que se pode ler efetivamente. A ausência da palavra "bota", no caso apresentado, não impede sua leitura quando retomam o texto.

\subsubsection{Reflexões sobre a estrutura das parlendas}

As parlendas, textos de tradição oral, costumam ser apresentadas por escrito com uma estrutura similar a dos poemas: a cada novo verso inicia-se uma linha (Quadro 4, p. 102). Kaufman (In KAUFMAN; RODRIGUEZ, 1995, p. 23 e 24), referindo-se aos poemas, destaca esse aspecto da estrutura, que também pode se aplicar ao caso das parlendas: 
as linhas curtas [...] dão relevância aos espaços em branco; então, o texto emerge da página com uma silhueta especial que nos prepara para sermos introduzidos nos misteriosos labirintos da linguagem figurada.

\section{QUADRO 4 - ESTRUTURA DAS PARLENDAS ${ }^{21}$}

\section{Parlenda 1}

UM, DOIS, FEIJÃO COM ARROZ

TRÊS, QUATRO, FEIJÃO NO PRATO

CINCO, SEIS, FEIJÃO INGLÊS

SETE, OITO, COMER BISCOITO

NOVE, DEZ, COMER PASTÉIS.
Parlenda 2

A GALINHA DO VIZINHO

BOTA OVO AMARELINHO

BOTA UM,

BOTA DOIS,

BOTA TRÊS

BOTA QUATRO,

BOTA CINCO,

BOTA SEIS,

BOTA SETE,

BOTA OITO,

BOTA NOVE

E BOTA DEZ.

Em relação à parlenda escrita no papel - parlenda 1 -, na maior parte das vezes, foi mantida a estrutura conforme quadro acima. Era comum que as crianças se orientassem pela numeração contida no texto: a cada novo par de números, a mudança de linha era automática. No entanto, algumas duplas tiveram a necessidade de discutir essa questão, como fez a dupla 7:

Angela: Agora, escreve três, quatro.

Vitor: Três (ele inicia a escrita na mesma linha do verso anterior)

Angela: Não, aqui, aqui (indica a linha de baixo)

Vitor: Não tem que sê aqui? (pergunta para mim)

E: O que vocês acham?

Angela: Acho que tem que continuar na outra linha porque é diferente.

Vitor: Mas é a mesma! É a mesma parlenda.

Angela: Ai, tá. Já entendi. A parlenda tem que ser toda junta! (concorda com o colega aceitando a escrita na mesma linha)

Vitor: (escreve 34 na mesma linha em que grafou o verso anterior)

\footnotetext{
${ }^{21} \mathrm{O}$ quadro apresenta a versão da parlenda 1 mais citada pelas crianças. Porém, algumas duplas apresentaram versos diferenciados para a composição dessa parlenda, sem que isso comprometesse sua estrutura. No caso da parlenda 2, a versão foi a mesma em todas as produções.
} 
Ainda que tenham tomado uma decisão diferenciada e optado por escrever a parlenda de forma contínua - sem marcar os versos -, pode-se afirmar que também essas crianças estavam atentas à estrutura e reconheciam diferentes possibilidades de organização textual. As justificativas que apresentam - "é a mesma parlenda” e "a parlenda tem que ser toda junta" sinalizam que são capazes de observar e refletir sobre esse aspecto da produção escrita, explicitando informações que já possuem, entre as quais: saber que os textos podem ter configurações diversas no papel; saber que, muitas vezes, um mesmo texto merece ser escrito continuamente e se faz uma mudança de linha quando um novo texto se inicia. Além disso, podese supor que a escrita contínua esteja atrelada ao fato de que as crianças estão acostumadas a recitar, a falar as parlendas, diferente do que ocorre com outros textos que produzem e que não se prestam à recitação. A fala não tende a marcar fortes separações entre as palavras ou entre os versos, o que faz com que a parlenda seja mesmo recitada sem qualquer segmentação, originando também um texto contínuo, “todo junto”.

A parlenda 2, produzida no computador, impossibilitou mudanças automáticas de linha, assim como no caso da lista de bagagem para a montanha: algo precisava ser teclado para que isso acontecesse. Esse diferencial, somado à própria estrutura interna da parlenda - com a repetição excessiva de uma expressão e não tendo números para marcar o início de cada verso fez com que a opção mais regular entre as duplas tenha sido a produção contínua, somente mudando de linha quando não houvesse mais espaço na anterior, o que, nesse caso, também era delimitado pela própria configuração das margens no Word. A produção de Angela e Vitor, apresentada no item 4.3 .2 (p. 100), também serve para ilustrar essa ocorrência.

Vale, porém, salientar que somente uma das duplas escreveu a parlenda se aproximando da organização apresentada no Quadro 4 (p. 102), exatamente as mesmas crianças que escreveram o texto repetindo a expressão "bota” nos versos redigidos, escolha que, em relação à estrutura, também pode ter justificado as mudanças de linha.

Clara: Já escreveu bota ovos?

Pedro H.: Já. Tá aqui (indica no monitor as grafias correspondentes a essas palavras)

Clara: Agora é B, Ó...

Pedro H.: B... (diz a letra e digita dando continuidade ao texto, sem segmentar ou mudar de linha)

Clara: Não, não! Agora, muda de linha que vai começar o bota um, bota dois...

Pedro H.: Como apaga mesmo?

Clara: Esse (indica a tecla "backspace") 
Pedro H.: (apaga, muda de linha teclando “enter” e digita BO)

$\mathrm{P} 2 / \mathrm{D} 8$

Clara manteve, ao longo da produção, a preocupação com a mudança de linha a cada repetição de "bota”, algo que seu colega não realizava autonomamente. Em outros momentos da composição do texto, Pedro $\mathrm{H}$. continuou a escrita na mesma linha e sua parceira chamou a atenção para tal fato, reiterando a importância da mudança.

\subsubsection{Revisão: avaliando e controlando a produção}

Assim como se deu no caso das listas, a revisão das parlendas, seja durante a produção, seja ao final dela, não se deu de modo sistemático. Novamente, estava em jogo muito mais a intenção de controlar o texto do que realmente a inserção de mudanças no mesmo. Na maior parte das vezes, a revisão tinha como meta descobrir o que já tinham escrito e o que restava escrever. Isso também aconteceu na produção das listas, mas naquelas situações era mais comum que pedissem a ajuda da investigadora. No caso das parlendas, ao contrário, as próprias crianças realizavam essa retomada do texto, por já o saberem de memória, tentando orientar-se por índices nele presentes, como a numeração:

Bruno: Deixa eu ver onde a gente tá... Deixa eu ficar aqui. Vou ler (ele se senta na cadeira do amigo, ao invés de puxar a folha para si, e começa a recitar. Antonio o acompanha, mas sem olhar o texto)... Um, dois, feijão coarroz (seguem repetindo a parlenda enquanto Bruno vai se orientando pelos números escritos - indicando-os com o dedo - para controlar a produção)

Antonio: Já sei, agora é nove, dez, comer pastéis. Não é? (diz assim que terminam de recitar o trecho escrito)

Bruno: É isso. Só falta essa parte pra acabar.

P1/D6

Apenas duas duplas demonstraram a preocupação de verificar a escrita da parlenda depois de concluir o texto e também foram capazes de retomá-lo, realizando a leitura, como no exemplo, sem solicitar qualquer apoio. 
Ainda no que diz respeito à revisão houve, no caso das parlendas, uma diferença na quantidade de tentativas de controle da produção realizada no papel e no computador. Todas as duplas realizaram essa tarefa escrevendo no computador e com maior participação dos ditantes. Quando escreviam no papel, a tarefa de composição ficava restrita e muito mais visível para o escriba, como já se destacou na elaboração das listas. Por vezes, o ditante, imbuído da intenção de realizar uma leitura do texto, tomava o papel da mão do colega ou tomava mesmo seu lugar, como ocorreu com Bruno e Antonio no exemplo acima. Foi comum que, ao escreverem a parlenda “A galinha do vizinho", a cada nova palavra ou mesmo a cada trecho, as crianças recitassem, acompanhando com o dedo sobre o monitor, o texto desde o seu início, como mostram Camila e Jhoão:

Jhoão: Deixa eu ver onde está... A ga-li-nha...

Camila: Do vizinho (diz e digita DO)

Jhoão: A-ga-li-nha-do... vi-zi-nho

Camila (digita VI e olha para o monitor) Vi-zi-nho (digita ZINO)

Jhoão: A-ga-li-nha-do-vi-zi-nho... (diz e vai apontando no monitor onde está escrito cada parte)... bota...

P2/D5

De modo geral, avalia-se que a produção das parlendas trouxe para as crianças um desafio menor no que concerne à linguagem escrita: não havia uma intencionalidade para o texto que envolvesse a tarefa de leitura por parte de outras pessoas que não os próprios autores; não havia, ainda, um conteúdo a ser discutido e decidido, pois o texto já estava "pronto" antes de iniciarem sua elaboração. Em igual medida, pode-se afirmar que a divisão de tarefas - ditar e escrever - se desconfigura nesse caso visto que o escriba domina o texto tanto quanto o ditante, que, em algumas duplas e em vários momentos, acabou por atuar de forma menos comprometida.

\subsection{ALGUMAS CONSIDERAÇÕES}

As análises feitas e apresentadas até esse ponto destacaram discussões e decisões que as crianças observadas tomaram tendo em vista os aspectos discursivos do texto. Conhecimentos diversos sobre a linguagem escrita e sobre os procedimentos inseridos no processo redacional foram explicitados. Pode-se dizer que esses aprendizes ainda estão distantes de se apropriar das 
diferentes formas de discurso que existem socialmente e de resolver qualquer problema que a produção escrita demande. Entretanto, não se pode dizer que não sejam capazes de escrever e de se comunicar via escrita. As listas produzidas, por exemplo, centraram a atenção desses escritores no que se refere à adequação ao contexto e ao propósito da produção e, em versão final, boa parte delas atende perfeitamente a todos esses requisitos. Apesar da pouca experiência, esses pequenos foram capazes de refletir sobre o processo de composição de um texto e de tomar decisões evidenciando saberes em construção. De maneira geral, tiveram uma postura aberta ao enfrentamento dos problemas inerentes à produção, recorrendo à entrevistadora somente em casos de maior dificuldade. Do mesmo modo, pode-se afirmar que os intercâmbios estabelecidos resultaram em trocas e confrontos de informações favoráveis à ampliação dos conhecimentos em jogo.

Mesmo iniciantes no uso social da escrita, as crianças encaram a tarefa de produção sem resistências e parecem reconhecer a função desse instrumento e até sua complexidade, por exemplo, identificando a existência de formas diversas de discursos.

A análise das produções e dos percursos interlocutivos que as originaram não se finaliza aqui. No capítulo seguinte, tomar-se-á como referência as reflexões associadas aos aspectos notacionais, considerando as discussões sobre o sistema alfabético, suas regras e sobre o uso de outras marcas gráficas além das letras. 


\section{O PROCESSO DE PRODUÇÃO TEXTUAL: TENDÊNCIAS NOS ASPECTOS NOTACIONAIS}

[...] as crianças são facilmente alfabetizáveis; foram os adultos que dificultaram o processo de alfabetização delas.

(FERREIRO, 2003, p. 17)

A concepção de escrita que embasa, e de certa forma também justifica, a presente pesquisa nega a separação entre os conhecimentos sobre o sistema de representação e suas circunstâncias de uso, conforme já se discutiu no Capítulo 1. Por um lado, entende-se que a apropriação dos princípios que regem nossa escrita - atrelados ao sistema alfabético e suas normas - não se coloca como "um requisito prévio para a utilização da linguagem escrita como tal, para a interpretação e produção de textos escritos correspondentes aos diferentes gêneros que circulam socialmente” (LERNER, 2002, p. 40). Por outro lado, vivenciar situações de leitura e escrita de textos proporciona um amplo repertório de observações e reflexões por parte das crianças, tanto relacionadas aos aspectos discursivos da composição, como já se evidenciou, quanto à própria notação: a correspondência entre fonema e grafema, a possibilidade de letras diferentes para a representação de um mesmo som, a necessidade de segmentação entre as palavras, entre outros aspectos.

Em continuidade à análise dos processos de produção textual, pode-se afirmar que foram intensas e significativas as interlocuções entre os sujeitos observados no que diz respeito às reflexões e decisões sobre a notação. Tal interação permitiu o aparecimento de escritas atreladas a diferentes momentos conceituais, por vezes mais avançados do que se poderia esperar das crianças atuando individualmente. A isso se soma a importância de um procedimento, amplamente utilizado pelas duplas, de busca de referências em outras palavras para grafar os itens da lista ou mesmo os vocábulos que compunham as parlendas.

Outro ponto crucial desta análise será marcar e diferenciar a apresentação de alguns dos aspectos identificados, considerando o tipo de suporte ou recurso utilizado: o papel e o computador. Ao contrário do que ocorreu em relação aos aspectos discursivos, a grande variação que se observou em algumas discussões sobre os aspectos notacionais não estavam associadas ao tipo de texto em jogo - lista ou parlenda -, mas às possibilidades de escrita com lápis e papel ou com o uso do teclado e alguns dos recursos do processador textual. O emprego de marcas 
gráficas, além das próprias letras, e tentativas de segmentação foram evidentes, sobretudo, durante as produções no computador e serão aqui tematizados.

O quadro abaixo situa a organização do presente capítulo.

\section{QUADRO 5 - ORGANIZAÇÃO DO CAPÍTULO 5}

\begin{tabular}{|c|c|c|}
\hline $\begin{array}{l}\text { 5.1. A produção escrita e o processo de } \\
\text { compreensão do princípio alfabético }\end{array}$ & $\begin{array}{l}\text { 5.1.1. As produções de Beatriz } \\
\text { e Luiz } \\
\text { 5.1.2 As produções de Clara e } \\
\text { Pedro H. } \\
\text { 5.1.3. Interações e momentos } \\
\text { conceituais }\end{array}$ & \\
\hline $\begin{array}{l}\text { 5.2. Planejando e revisando: antecipar e } \\
\text { retomar escritas } \\
\text { 5.3. Procedimentos de busca de } \\
\text { informações: as palavras estáveis, as } \\
\text { palavras de referência e as relações } \\
\text { sonoras }\end{array}$ & & \\
\hline $\begin{array}{l}\text { 5.4. O computador: tarefas e reflexões } \\
\text { possíveis }\end{array}$ & $\begin{array}{l}\text { 5.4.1. O teclado como fonte de } \\
\text { informação } \\
\text { 5.4.2. O computador } \\
\text { ampliando as interações entre a } \\
\text { dupla } \\
\text { 5.4.3. Além do princípio } \\
\text { alfabético: a segmentação e o } \\
\text { uso de outras marcas gráficas } \\
\text { 5.4.4. Números e letras: dois } \\
\text { sistemas notacionais na } \\
\text { produção de textos }\end{array}$ & $\begin{array}{l}\text { 5.4.3.1 A segmentação } \\
\text { 5.4.3.2. Outras marcas } \\
\text { gráficas: os acentos }\end{array}$ \\
\hline 5.5. Algumas considerações & & \\
\hline
\end{tabular}

\subsection{A PRODUÇÃO ESCRITA E O PROCESSO DE COMPREENSÃO DO PRINCÍPIO ALFABÉTICO}

Previsivelmente, os processos de produção deram origem a textos que demonstraram a amplitude dos conhecimentos já construídos por seus autores em relação à escrita convencional. 
Em se tratando de escritores ainda iniciantes e pouco experientes, era esperado que hipóteses diversas sobre como escrever predominassem nas produções.

Com base nos momentos conceituais identificados na pesquisa psicogenética, pode-se dizer que foram produzidas desde escritas em estágio mais inicial desse processo até outras mais elaboradas, passíveis de leitura quase que convencional por conterem somente omissões ou trocas de letras, que pouco comprometem a interpretação do texto. Não se observou uma relação direta entre as hipóteses de escrita dos sujeitos e sua série escolar de origem, ou seja, os menores não necessariamente apresentaram escritas mais distantes da convencional. Em ambos os grupos escolares pesquisados, foram encontradas produções relativamente avançadas, como as escritas silábico-alfabéticas.

A exposição e análise dos processos e produções de duas duplas, que se faz a seguir, têm como objetivos explicitar a diversidade da escrita e a natureza dos intercâmbios entre os pequenos escritores.

\subsubsection{As produções de Beatriz e Luiz}

Para fins de análise dos aspectos notacionais relacionados ao princípio alfabético, as primeiras produções eleitas pertencem à dupla Beatriz (3/4.10) e Luiz (3/5.5) ${ }^{22}$. Beatriz atuou como escriba e, na primeira produção (lista de viagem para a praia), tomou sozinha todas as decisões relativas à escrita das palavras, não contando com a colaboração direta de seu colega. Poucas também foram as intervenções sobre a grafia feitas por Luiz na elaboração do segundo texto, a parlenda “Um dois, feijão com arroz....”. Nas páginas seguintes encontram-se essas duas produções, acompanhadas de uma transcrição que apresenta o conteúdo das mesmas e as linhas as quais se referem:

\footnotetext{
${ }^{22}$ Conforme referência já utilizada no Capítulo 3, os números indicam série escolar e idade respectivamente.
} 
Produção da lista 1:

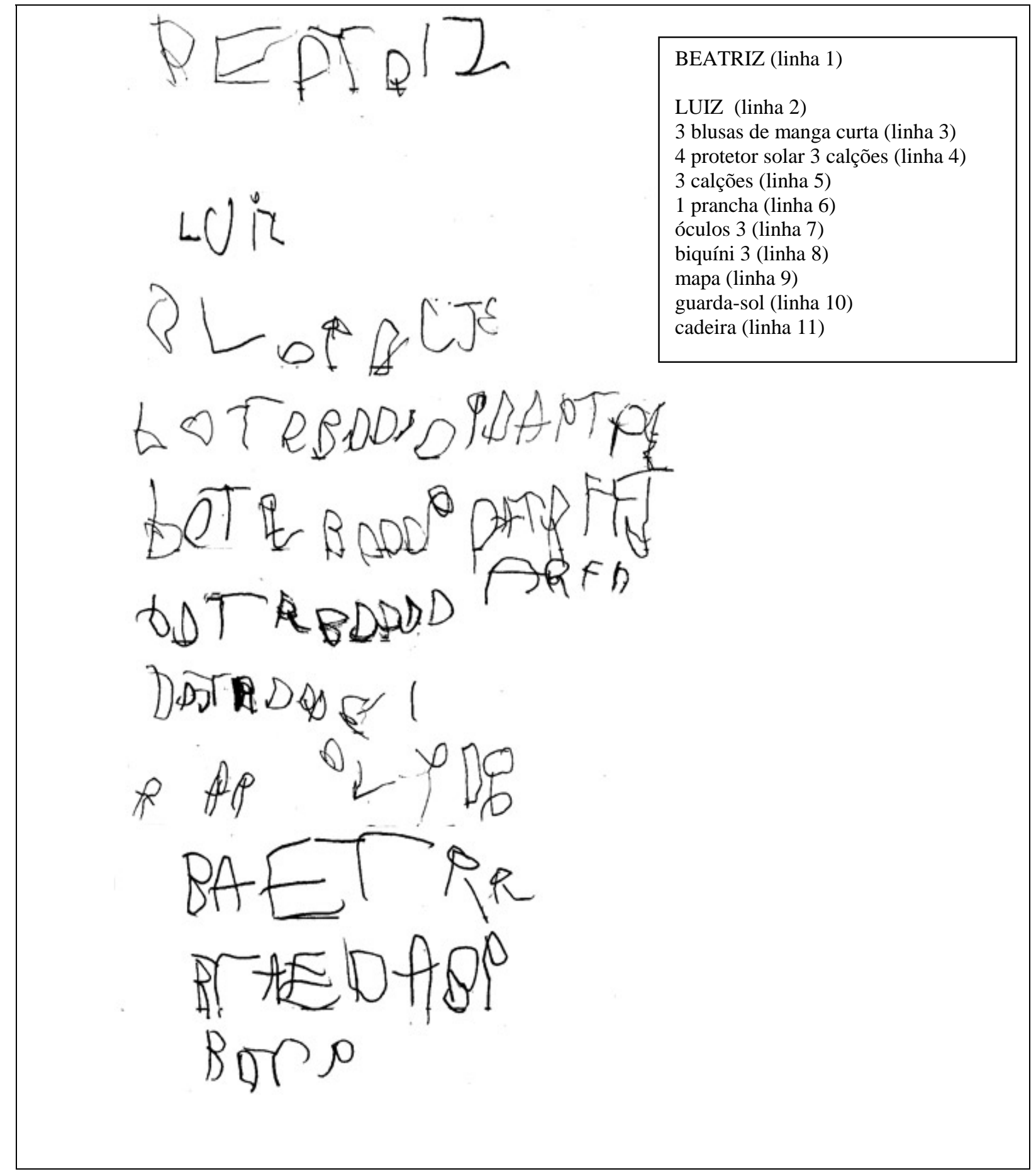


Produção da parlenda 1:

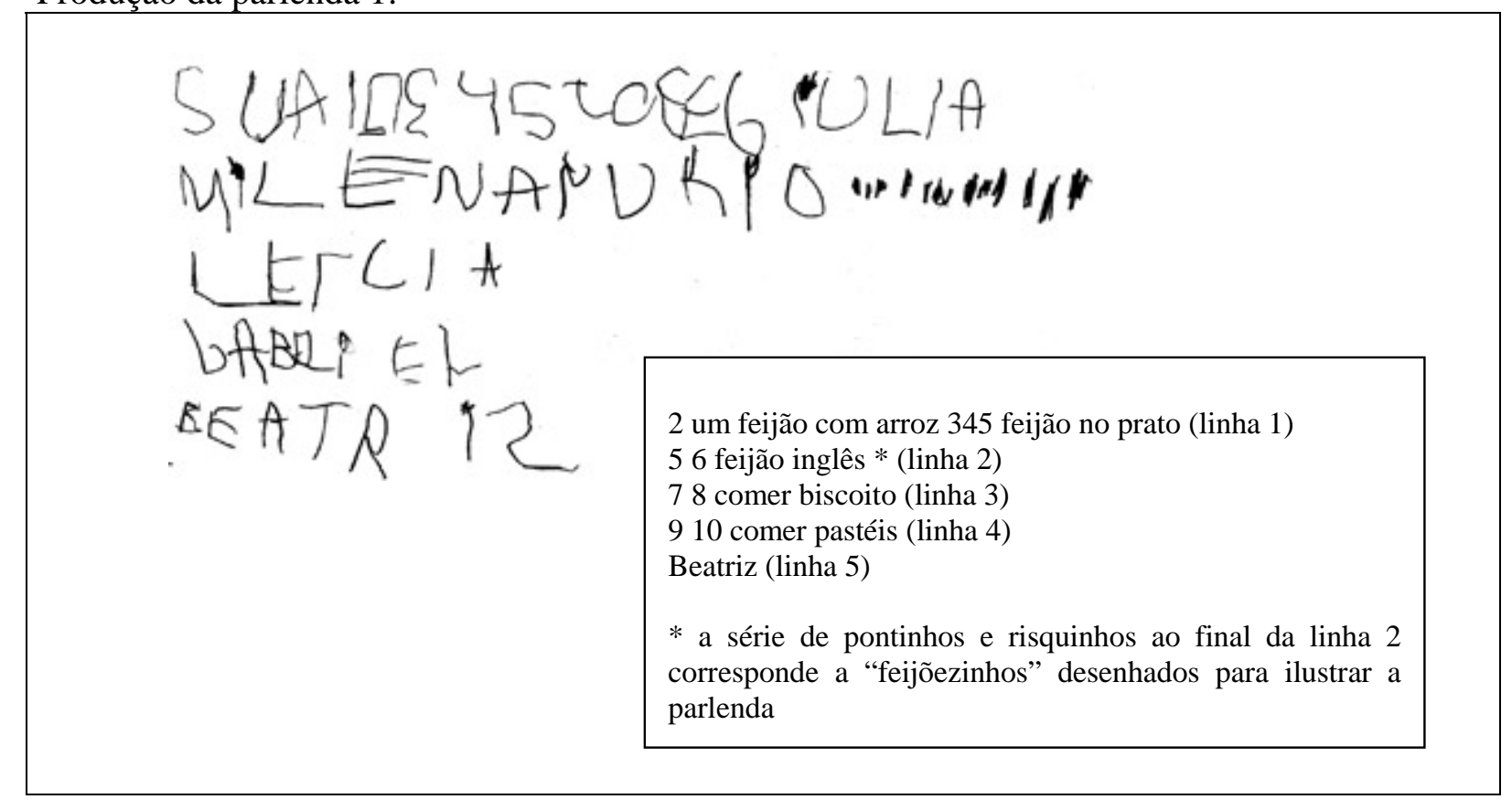

Beatriz revela, nessas produções, uma escrita marcada pela utilização de quaisquer letras, sem correspondência com o valor sonoro convencional. Utiliza não apenas letras pertencentes ao nosso sistema, como também símbolos que a elas se assemelham, visíveis na lista (como na linha 8, último símbolo). Pode-se afirmar, contudo, que tem uma intensa preocupação com a necessidade de variar os símbolos, tanto para grafar uma palavra quanto para diferenciar um vocábulo do outro. Um bom exemplo, aqui, seria a utilização de seu próprio nome, porém cuidando de alterar a seqüência das letras que o compõem, como se nota na linha 11 da lista.

Esse aspecto é tão valorizado por Beatriz que, até ao copiar um trecho, faz modificações na seqüência. Precisamente ao escrever “três calções” (linha 4), ela não realizou a necessária mudança de linha. Seu parceiro chamou sua atenção para o fato (e foi essa a única intervenção que realizou acerca da estrutura do texto) e ela se dispôs a copiar, na linha abaixo, o que julgava ser a parte relativa a essa expressão. Como se pode ver na própria produção, apenas um trecho da linha 5 (correspondente a "3 calções”) é semelhante à grafia composta na linha anterior (4), alteração que Beatriz faz explicitamente, afirmando: “Agora já copiei um pedaço. Agora vou fazer diferente.”

Essa criança demonstra, ainda, reconhecer a importância de uma quantidade mínima de caracteres para compor uma escrita, produzindo longas seqüências, como se percebe na lista, ou 
seqüências menos extensas, como na parlenda, tendo sempre mais de duas ou três letras, como é comum observar em crianças que assim conceitualizam a escrita.

Outro conhecimento importante, já dominado por Beatriz, relaciona-se à direção da escrita em nosso sistema, visto que em ambos os textos inicia a grafia do lado esquerdo da folha.

Ao longo dos dois processos de produção aqui analisados, não há evidências de preocupações com o valor sonoro e com suas respectivas correspondências gráficas. Beatriz parece estar no início de seu processo de apropriação da escrita, embora já domine dois importantes conceitos atrelados a legibilidade (quantidade mínima de caracteres) e interpretabilidade (variação de caracteres) que, de fato, correspondem a características do nosso sistema.

Não se observou entre as demais duplas uma produção de caráter pré-silábico, como se nota na escrita de Beatriz. Entretanto, a diversidade de conceitos já assimilados pelas crianças pode ser ratificada tomando-se como referência a análise do processo de outra dupla.

\subsubsection{As produções de Clara e Pedro H.}

Os processos de produção textual de Clara (4/5.7) e Pedro H. (4/5.9) foram bastante diferenciados, se comparados ao restante das duplas. Clara, tendo o papel de ditante, realizou intervenções sistemáticas e ininterruptas sobre a escrita das palavras, ditando letra a letra. Pedro H., como escriba, deixou de tomar decisões sobre a grafia, aguardando o ditado da colega. De modo efetivo, pode-se afirmar que as decisões notacionais ficaram sob a responsabilidade de Clara, sendo possível identificar, nos textos, em suas falas e em suas ações no decorrer dos processos de composição, alguns de seus conhecimentos sobre o sistema de representação.

Nas próximas páginas serão apresentadas as produções dessa dupla, primeiramente, a lista de viagem para a praia e, na seqüência, a parlenda “Um, dois, feijão com arroz...”. Fez-se a opção de analisar o processo de Clara tomando-se como exemplos as produções dos mesmos textos que favoreceram a tematização do percurso de Beatriz, já descrito. 
Produção de lista 1:

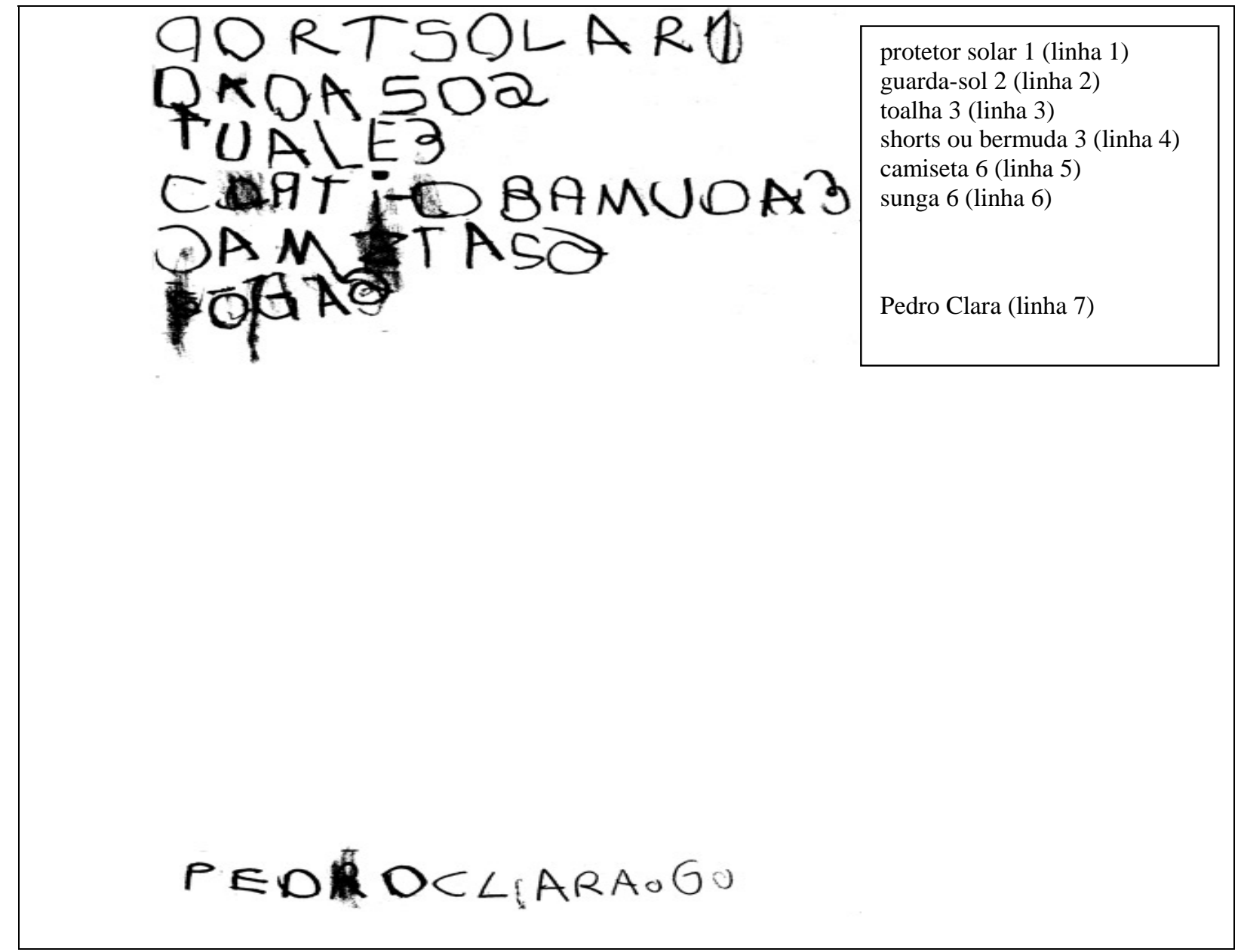

Produção da parlenda 1:

$$
\begin{aligned}
& \text { 1QFE DURDIS- } \\
& 347 \exists \partial I S N N Q R T O \\
& 75 \partial \text { EEDELES } \\
& \text { H-79COM ERO IPNCOTO } \\
& \text { Y IOCON EQ ASIFBS }
\end{aligned}
$$

12 feijão com arroz (linha 1) 34 feijão no prato (linha 2) 56 feijão inglês (linha 3) 78 comer biscoito (linha 4) 910 comer pastéis (linha 5) 
A produção da lista mostra que Clara já compreendeu a fonetização da escrita. Ainda que não realize sistematicamente a representação de todos os fonemas, já é capaz de fazer o que Teberosky (2003, p. 56) chama de “análise interna da sílaba”, utilizando, em geral, mais de uma letra para grafar cada sílaba.

Algumas omissões e trocas são, efetivamente, esperadas nesse momento conceitual, tais como a ausência da letra E acompanhando o T de "protetor" (linha 1 da lista) e o Z de "camiseta" (linha 5 da lista). Nesses casos, o nome da letra é considerado referência para a composição da sílaba e a necessidade do E será observada mais adiante no processo de construção da escrita. O mesmo se pode dizer em relação à alteração na ordem das letras. Ao ditar "pro”, de "protetor”, por exemplo, Clara repetiu, em voz alta, várias vezes essa sílaba, dizendo que sabia da existência de $\mathrm{P}$, O e R, mas não conseguia identificar exatamente onde deveria "ficar" essa última letra. Depois de refletir algum tempo, Clara optou pela seqüência “por”. Encontros consonantais e dígrafos, como o LH de “toalha” (linha 3), ainda não são problemas de fácil resolução nessa etapa do processo.

Do ponto de vista da interpretação, Clara conseguiu, em algumas situações, retomar as escritas feitas, realizando uma leitura convencional. Esse fato pode ser exemplificado na leitura de “dada”, feita ao retomar a grafia correspondente à "guarda” (linha 2 da lista). Clara a leu foneticamente e, logo em seguida, perguntou-se: “O que é isso? Dada?”. Depois de seguir na leitura do que identificou como "sol” (ainda na linha 2), ela conseguiu atribuir um significado: “Ah! Deve ser guarda-sol. Esse deve ser o 'guar', que tava difícil”, disse apontando o "da" inicial. Ainda que não sirva para resolver o problema da grafia de uma sílaba mais complexa, a retomada da palavra, feita por Clara sem qualquer apoio, demonstra também sua capacidade de identificar aspectos duvidosos de seu próprio texto e sua possibilidade de interpretá-lo.

Vale reiterar que ler de maneira convencional não foi uma tarefa realizada sistematicamente por essa pequena escritora. Em outros momentos, a ação de reler para identificar o que havia sido escrito tornava-se possível por meio de pistas que ela mesma localizava na produção, por exemplo, lembrando-se de que a única coisa que começava com P era “protetor solar”, na lista de bagagem para a praia.

Uma análise superficial da elaboração da parlenda pode levar à suposição de que houve algum tipo de regressão por parte de Clara ou mesmo que ela tenha deixado a cargo do colega 
tomar decisões sobre a grafia. Mas é possível se buscar justificativas diferenciadas para as omissões presentes, principalmente, nas três linhas iniciais.

Foi, de fato, Clara quem se manteve decidindo com que letras grafar cada trecho. Ocorre que ela, assim como outras crianças nesse momento conceitual, apresenta dificuldades para manter a correspondência fonográfica quando se trata da produção de frases e não de palavras isoladas. Na parlenda, há a necessidade de se escrever expressões que, muitas vezes, não são analisadas palavra a palavra.

Para Clara, ainda não foi possível construir uma idéia precisa de "palavra gráfica” como uma importante unidade de nosso sistema. Essas unidades, separadas por espaços em branco, não são facilmente observadas por quem ainda não domina a escrita alfabética e não lê de modo convencional. Por essa razão, os recortes sonoros que Clara realizou ao ter que identificar as letras na lista e na parlenda diferem entre si. Ao ter que pensar sobre palavras isoladas, ela considerou as sílabas; ao contrário, com a tarefa de pensar sobre a escrita de um trecho mais extenso, não analisou as palavras em separado, mas, a partir dos conhecimentos e experiências que possui em relação à linguagem oral, pautou-se em uma segmentação "indicada pela acentuação em grupos prosódicos muito mais longos do que as palavras gráficas”. Quando recita a parlenda, Clara, tampouco seu colega, não dizem isoladamente "feijão com arroz", mas “feijãocoarroz”, como é mais usual, uma tendência já apontada por Teberosky (2003).

Por esse motivo, Clara não conseguiu controlar sistematicamente a escrita de todas as sílabas de cada palavra que compõe a parlenda. Ao longo da produção, ela mesma ampliou suas possibilidades de análise sonora e, principalmente nos dois últimos versos (linhas 4 e 5 da parlenda), apresentou uma escrita mais próxima à convencional e similar ao que fez na elaboração da lista exemplificada. Assim como Clara, outras duplas apresentaram produções mais próximas à convencional, marcadas por algumas trocas e omissões comuns nesse momento conceitual.

A retomada das produções de outras duplas também permite identificar conceitos diversos construídos por esses escritores-aprendizes em suas trajetórias de apropriação da escrita alfabética. Vale reiterar que não apenas o resultado das produções foi contemplado na presente análise, mas, prioritariamente, o acompanhamento dos processos de produção, o que revelou inúmeras pistas do que pensam e concebem esses sujeitos. Assim, as discussões entre as crianças foram marcadas pelas idéias que tinham acerca da escrita convencional. O que ocorre, entretanto, 
é que não se pode estabelecer uma relação direta entre a concepção de escrita que se identifica no texto em versão final e os conhecimentos de uma das crianças da dupla - como feito com as produções de Beatriz e Clara -, por causa das interações estabelecidas, aspecto que será mais bem abordado no próximo tópico e retomado no capítulo 6.

Feita essa ressalva, é importante destacar que, no processo de produção de algumas outras duplas, também a hipótese silábica pautou decisões sobre a escrita, permitindo que um pequeno repertório de letras - as vogais, sobretudo - fosse utilizado para as grafias curtas que caracterizam esse período. Repetições seguidas de letras eram possíveis, pois, de forma sistemática, faziam corresponder um grafema para cada sílaba, como se identifica na produção de Pedro (3/5.4) e João (3/5.4).

Produção de trechos da lista 1:

\begin{tabular}{|l|l|}
\hline & $\begin{array}{l}\text { pás 3 (linha 1)* } \\
\text { peixe 3 (linha 2) } \\
1 \text { bola (linha 3) } \\
\text { foto 3 (linha 4) } \\
\text { * palavra lida pelo escriba } \\
\text { como pá em A e ás em I: pá- } \\
\text { ás) }\end{array}$ \\
\hline
\end{tabular}

Outras parcerias, por exemplo, que já reconheciam a necessidade de usar mais de uma letra para cada sílaba, realizaram tentativas constantes para identificar grafemas necessários, intercambiando idéias sobre a escrita. Era comum que localizassem facilmente a vogal e ficassem a refletir sobre quais outras letras deveriam utilizar, como se nota no exemplo abaixo:

Daniel: Solar. Agora, escreve solar.

Flora: So, so, so... Tem O, O!

Daniel: Ssso, ssso... E o S!

Flora: E o O. (escreve SO)... lar, lar, lar, lar...

Daniel: O A.

Flora: E tem o L também. (escreve AL) 
Como resultado, essa dupla apresentou produções silábico-alfabéticas muito próximas à convencional, com omissões, trocas e inversões similares às de Clara (apresentadas anteriormente).

Com os exemplos apontados até aqui, pode-se concluir que a diversidade de concepções sobre como escrever se evidencia nos processos de produção textual. As crianças partiam dos saberes já construídos ao tomar decisões sobre a grafia das palavras. Mas, como se destacou acima, intercâmbios se estabeleceram entre as crianças e foram fundamentais para ampliar as decisões tomadas. Dada a interação instaurada, não bastava que explicitassem individualmente suas idéias, era preciso confrontá-las com as do parceiro escritor. Pela importância que esta pesquisa atribui à interação, o item a seguir discorrerá sobre as diferentes formas de intercâmbio observadas nas situações de produção.

\subsubsection{Interações e momentos conceituais}

Até esse ponto, discorreu-se sobre os diferentes momentos conceituais que fundamentaram a escrita das crianças, resultando em produções bastante variadas. Os comentários pautaram-se principalmente nos textos e reflexões de Clara e Beatriz, que, nas produções realizadas no papel, atuaram sozinhas ao tomar decisões sobre a grafia das palavras. A ausência de interlocução, porém, não foi algo recorrente. Ao contrário, o mais observado entre as duplas foi justamente uma intensa troca (como ocorreu nas decisões sobre o conteúdo do texto, por exemplo, descritas no capítulo anterior) e até discussões mais acirradas, na tentativa de resolver os problemas impostos pela escrita das palavras e também pelas segmentações e usos de outras marcas gráficas de nosso sistema, como se apresentará mais adiante.

Foram intercâmbios bastante variados, a julgar pela atuação de cada criança da dupla e pelo papel que exerceram na composição do texto. Na maior parte das duplas, escriba e ditante ocupavam-se de decisões sobre a escrita das palavras, como mostra o exemplo do diálogo entre Flora e Daniel, acima. Esse tipo de interação trazia também inúmeros conflitos visíveis nos processos de elaboração. Decidir a grafia de uma palavra, quando não se domina a escrita alfabética, representa um imenso desafio para um escritor-aprendiz. Realizar essa tarefa em parceria acarreta um desafio ainda maior, devido aos confrontos que ocorrem. Há que se ponderar que crianças pequenas, como as observadas nessa pesquisa (entre 4 anos e 10 meses e 6 anos e 9 
meses), são pouco experientes no trabalho cooperativo, o qual exige divisões de tarefas, discussões e consensos. Mesmo vivendo cotidianamente na escola propostas didáticas realizadas em duplas ou pequenos grupos, não se pode dizer que dominem completamente as atitudes e procedimentos que a tomada partilhada de decisões demanda.

Segue, abaixo, um exemplo da que foi, certamente, a mais acirrada discussão que se estabeleceu e que exigiu, inclusive, uma intervenção da pesquisadora.

Bruno: Agora é com arroz...

Antonio: Com. Como é que faz com?

Bruno: É C O.

Antonio: (escreve Q)

Bruno: (olha para o papel) Não é Q, é C O.

Antonio: Então, como é que é?

Bruno: É o C. (ele puxa o papel para si e apaga o Q feito)

Antonio: Pára, Bruno, que droga! Eu que faço! (Antonio grita com o colega, pega o papel de volta e refaz o Q)

Bruno: É que ele está aprendendo a ler e eu já sei. (diz em tom irritado dirigindo-se a mim)

Antonio: Eu sei ler...

Bruno: Não sabe, não!

Antonio: Sei, sim. Eu sei ler gibi.

Bruno: Gibi?... Só isso? (grita com o colega)

E: Vocês dois são bem sabidos de ler e escrever. Agora, estão pensando sobre duas letras diferentes para resolver o problema de uma palavra. Não é preciso brigar! Vamos pensar melhor para escolher a letra mais adequada, está bem?

Antonio: E se a gente pensar em outra palavra, que também tem co?

Bruno: É. Vamos ver... Já sei! Ali, olha! (aponta para o mural da classe em que estamos, indicando a lista de personagens da Turma da Mônica). Ali tem co, no Chi-co. Aqui, olha (vai até o mural indicar a escrita de Chico Bento). É o C.

Antonio: Tá mesmo escrito com C... Eu acho que eu me enganei...

Bruno: É, dessa vez. Deve ter outras palavras com Q, do jeito que você tava pensando.

Antonio: (escreve CO)

Nesse caso, mesmo que o conflito tenha gerado um desentendimento entre a dupla, favoreceu também a busca por uma estratégia favorável à resolução da grafia da palavra. Vale ressaltar que, assim como acontece em sala de aula, a situação exemplificada exigiu uma intervenção pontual de um adulto. Justamente pela pouca experiência das crianças na divisão de tarefas e pela diversidade de saberes que possuem, a mediação do professor é essencial. Esses pequenos escritores precisam do apoio sistemático de um mediador que incentive a explicitação 
de idéias, o respeito a diferentes saberes e a possibilidade de resolução de impasses. Como destaca Zabala (1998, p. 92):

do conjunto de relações interativas necessárias para facilitar a aprendizagem se deduz uma série de funções do professores (...):

g) Estabelecer um ambiente e determinadas relações presididos pelo respeito mútuo e pelo sentimento de confiança, que promovam a auto-estima $e$ o autoconceito.

h) Promover canais de comunicação que regulem os processos de negociação, participação e construção. (grifos do autor)

Ainda que casos de discussões mais acirradas ou de ruptura entre a parceria possam se instaurar, e até ameacem a produção da tarefa, há certamente espaços férteis para a intervenção pedagógica, já que, sob a ótica educacional, investir no respeito mútuo e na possibilidade de intercâmbio é um aspecto tão importante quanto a própria compreensão da escrita.

De fato, mesmo que momentos mais disputados tenham se estabelecido e que a intervenção da investigadora tenha sido necessária - o que, felizmente, não foi o mais comum os impasses explicitados pelas diferentes duplas tenderam a colocá-las em uma situação de reflexão intensa sobre nosso sistema de escrita, uma vez que não bastava opinar sobre a letra a ser usada, era preciso justificar a escolha.

Nas palavras de Teberosky (2003, p. 118),

Compartilhar a produção da escrita de palavras e de textos é parte do ambiente social; [...] a aprendizagem deve ser realizada em situações compartilhadas, que possibilitem a interação social entre as crianças [...].

E em texto elaborado em co-autoria com Ribera, Teberosky (In TEBEROSKY; GALLART, 2004, p. 67) vai adiante nessa análise:

Na situação de escrita entre uma dupla de crianças se põe claramente em evidência essa interação e as aprendizagens a partir de escrever e ler a própria escrita, sobretudo quando se dá entre diferentes concepções sobre como se escreve.

A produção em parceria, ou mesmo em pequenos grupos, supõe, efetivamente, confrontos. Trata-se da composição cooperativa de um texto; uma co-autoria que implica 
intercâmbios específicos sobre a escrita e ainda a possibilidade de atuação em papéis diferenciados durante o processo de produção. $\mathrm{O}$ anúncio da proposta de elaboração dos quatro textos solicitados às crianças vinha acompanhado da definição dos papéis que cada qual exerceria: um escriba e um ditante. Era esperado, porém, que se efetivassem trocas nesse sentido, inclusive atreladas à grafia das palavras, o que realmente se notou. Raras foram as situações em que cada criança se limitou ao papel que lhe fora destinado; as crianças alternavam a tomada de decisões, consultavam o colega quando tinham dúvidas e partilhavam problemas, na tentativa de encontrar maneiras de solucioná-los. Entretanto, esses intercâmbios relacionados à escrita das palavras não se manifestaram de forma semelhante nas diferentes duplas observadas.

Em boa parte das parcerias, o que se notou foram discussões acerca da grafia da palavra. A decisão sobre o que escrever vinha seguida do como fazê-lo. Interessante apontar aqui que, de maneira recorrente, a oralização, feita por uma das crianças, de partes sonoras da palavra em jogo permitia a intervenção do colega. Quando as crianças não escrevem alfabeticamente e precisam decidir que letras utilizar, já considerando a quantidade de sílabas e/ou seu valor sonoro convencional, é comum que fiquem a repetir em voz alta a parte que irão grafar: ouvir a sílaba pausada e seguidamente favorece, por vezes, a identificação dos grafemas correspondentes ou, ao menos, mais próximos às convenções do sistema. Essa ação também acabava por favorecer a participação do parceiro, que, ouvindo a parte sonora oralizada pelo colega, passava a partilhar do mesmo problema e muitas vezes até o solucionava, como nos exemplos que se seguem:

Bruno: Fejão, agora.

Antonio: Fê, fê, fê, fê, fê...

Bruno: Fê tem o F.

Antonio: Fê, fê... Tem o F e o E?

Bruno: O E também, mas depois.

Antonio: (escreve FE)

P1/D6 (Bruno: ditante/Antonio: escriba)

Bruno: Shampu... Como começa sham?...

Antonio: Como começa?...

Bruno: Sham, sham, sham... Parece nome japonês: sham...

Antonio: Parece que começa com C.

Bruno: Sham, sham...

Antonio: É. Dá pra ouvir C. (escreve C)

Bruno: E o resto? Sham, sham... an.... an... 
Antonio: $\mathrm{O}$ an do meu nome (escreve AN)

Bruno: Isso!

L1/D6 (Bruno: ditante/Antonio: escriba)

O exemplo de discussão demonstra não apenas a questão da oralização como forma de identificar as letras para escrever a palavra, como também uma alternância nos papéis de escriba e ditante. A cada momento, dependendo dos respectivos conhecimentos que possuem sobre a relação fonema-grafema, cabe a um ou a outro definir como escrever.

Situações como as apresentadas foram realmente muito freqüentes nas produções das crianças, que mostraram ainda a possibilidade de exercer outro papel diante da tarefa de escrever: o de leitor-crítico. Nesses casos, o que se verificou foi a criança-escriba decidindo como escrever, conforme papel que lhe fora atribuído inicialmente, e a criança-ditante avaliando a grafia composta, pela leitura posterior à escrita, seja para validá-la, seja para sugerir alterações ou acréscimos. Isso se observou no processo de algumas duplas, em situações isoladas, e de forma constante em três parcerias, como no caso abaixo:

Jhoão: Escreve um, dois...

Camila: (segue silabando baixinho e escrevendo: 12FEGNCUAROIS - espelha o N e o S)

Jhoão: (aproxima-se da colega e lê o que ela escreveu) Fei-jão-coa-ros. Tem que tirar o I, senão fica arroíss. Não é assim.

Camila: (apaga IS e refaz, tirando o I e colocando um S espelhado novamente)

Jhoão: Agora... no prato. Feijão no prato.

Camila: (segue escrevendo 34FEGNNURATO. Ela espelha os dois N)

Jhoão: (aproxima-se e lê) Fê-jão-nu-pra... É um P aqui (aponta a letra R).

Camila: Vai ficar pa-to

Jhoão: É P, R, A, T, O (diz soletrando)

Camila: (arruma seguindo a dica do colega)

Jhoão: Agora, ficou pra-to. Pronto.

A partir das colocações feitas até esse ponto, conclui-se que os intercâmbios foram intensos em relação à escrita das palavras e, certamente, estimulantes não apenas para a construção do texto, mas também para ampliar as reflexões e as idéias que as crianças elaboram sobre o sistema de escrita. Tais trocas entre os sujeitos-autores foram observadas ao longo de 
todo o processo de produção dos textos, tanto nos casos daqueles compostos com lápis e papel quanto nos digitados no computador, com variações, porém, na intensidade e sistematicidade com que ocorriam. No computador, como se verá mais adiante, a participação da dupla nas tomadas de decisões sobre como escrever foi mesmo mais freqüente. Antes de analisar essa diversidade, cabe discorrer, de modo específico, sobre o processo redacional: os procedimentos escritores e sua relação com as discussões acerca da grafia das palavras.

\subsection{PLANEJANDO E REVISANDO: ANTECIPAR E RETOMAR ESCRITAS}

Os procedimentos colocados em evidência por um escritor ao longo do processo redacional não se relacionam somente aos aspectos discursivos, mas também aos notacionais. É muito comum, ao escrevermos, anteciparmos a grafia correta de um termo ou definirmos previamente uma dada pontuação. Do mesmo modo, a revisão que realiza um escritor experiente funciona, inclusive, como uma forma de checar, entre outros aspectos, a grafia das palavras ou a pontuação utilizada.

Nos processos de produção dos textos analisados, verificaram-se ações constantes das crianças planejando e revisando a escrita de palavras. Tão logo definiam o que escrever, se dedicavam a discutir que letras comporiam a palavra ou o trecho. Em alguns casos, quando o escriba iniciava a tarefa de grafar, boa parte das letras já havia sido delimitada, como se constata na conversa entre Giulia e Guilherme:

Guilherme: Pode ser sunga... Como pode escrever sunga?...U UI... suun (fala prolongando o som do U)... Pode escrever do jeito que quiser? (dirigindo-se a mim)

E: Pode escrever do melhor jeito que você e a Giulia souberem.

Giulia: Sunga não tem I. Eu sei que não tem I... Acho que tem H, sun-ga (enfatiza o som ga). Mas eu não sei qual é o H

Guilherme: Mas não é H que começa. É o U e outro U... Su-un-ga.

Giulia: (escreve U duas vezes)

Guilherme: Agora pode ser o Y.

Giulia : (escreve algo que se parece com V)

Guilherme: Posso te ajudar? (Gui pega o lápis e faz o Y ao lado do traçado feito por Giulia, sem apagá-lo)

Giulia: E agora?

Guilherme: Agora, acabou?

Giulia: Acho que vai o H depois.

Guilherme: O H não vai.

Giulia: Como acaba sunga, então? 
Guilherme: Com A.

Giulia: (coloca um O e um A. Ambos dão a escrita por encerrada, compondo UUVYOA)

L1/ D1

Discutir antecipadamente a escrita de uma palavra não foi um aspecto que centrou a atenção somente de crianças, que, como Giulia e Guilherme, já se preocupavam com a análise da pauta sonora. Em outras duplas, ainda que sem contemplar a relação entre fonema-grafema, tomar decisões sobre as letras a compor uma palavra foi algo também colocado em jogo antes de se iniciar as grafias.

Quando as crianças não dominam o princípio alfabético de nossa escrita, a reflexão sobre com que letras - ou mesmo outros símbolos, em alguns casos - e em que quantidade é algo que gera tantas discussões quanto ao tomar decisões sobre o conteúdo do texto que elaboram. Antes mesmo de grafar a letra inicial da palavra desejada, reflexões foram feitas, confrontos se estabeleceram (como no uso de A ou H para representar o final de sunga no exemplo acima) e definições foram estipuladas, sempre com base nas hipóteses que tinham sobre a escrita convencional.

Como se nota, ainda pelo exemplo destacado, escriba e ditante mostraram-se capazes de planejar a escrita das palavras trocando idéias, explicitando suas hipóteses e tendo a necessidade de chegar a consensos.

Observou-se também um movimento constante dos sujeitos-escritores em revisar a grafia das palavras, seja para avaliar a produção (verificar se estavam de acordo com o que julgavam correto) ou mesmo para localizar termos já escritos ou partes dos mesmos no intuito de utilizá-los em outras situações.

No primeiro caso, a verificação se dava pela leitura, feita pelas crianças ou pela investigadora desde que solicitada pela parceria. Muitas vezes, a discussão sobre a grafia de um fonema ou de uma sílaba prolongava-se tanto que, quando iam dar continuidade à escrita, precisavam avaliar que partes já haviam sido grafadas e o que ainda restava ser escrito. Em outras situações, a intenção era mesmo avaliar a própria grafia, de acordo com critérios atrelados aos momentos conceituais das crianças, como se pode verificar na conversa entre esta dupla:

Pedro: Esqueve um carr-rro (diz prolongando e carregando no som forte do RR). Se alembei. 
João: Ca-rro (diz em voz alta e grafa AO)

Pedro:Você esqueve legal, sabia?

João: Olha, é ca-rro (Lê apontando para cada sílaba uma letra). Tem que ter duas letras mesmo.

Pedro: Esqueve um carro. Poque só a pofessoa sabe diigir, as quianças não.

J: (acrescenta 1 ao lado de AO)

P: Pode levá lupas pá vê os bichinhos da praa-ia.

J: Lu-pas... (diz em voa alta e escreve UA)

Pedro: Agora...

João: Não. Espera. Deixa eu ler... Lu-pa (novamente aponta uma letra ao emitir cada sílaba). Essa também tem que ter duas letras. Eu tenho que ir vendo como está ficando as palavras.

Ler para tomar emprestada a grafia de uma palavra já escrita no texto ou parte dela para dar continuidade à produção foi outra ação evidenciada pelas crianças, também de maneira recorrente, como se pode ver neste exemplo:

Flora: Sol, sol... Sol... eu não sei...

Daniel: A gente já escreveu em outro lugar...

Flora: Não. Acho que não.

Daniel: Escreveu. Quer ver... (olha atentamente a lista que estão compondo). Lê o que a gente escreveu?

(diz dirigindo-se a mim)

E: Vou ler para vocês (leio a lista toda). E agora?

Flora: Já escrevi sol. Aqui, no guarda sol (aponta a grafia que representa essas palavras)

Daniel: Sol está aqui (aponta desde o D de GADAÕSO)

Flora: (copia o que o colega indica, deixando de fora o O final e compondo assim a grafia de cadeira de sol: CDRADAÕS).

Daniel: (observa atentamente a grafia feita) É “só-ou” (diz enfatizando o OU final). Falta um O

Flora: (coloca o O)

Daniel: E tem que colocar O aqui também (diz indicando a grafia de guarda sol que tinham finalizado com S)

Flora: (acrescenta um $\mathrm{O}$ ao final da grafia de guarda-sol)

No exemplo não apenas se retoma uma escrita já feita como também se revisa a mesma, com o acréscimo de uma letra. Por um lado, essas crianças reconhecem a possibilidade de consultar o próprio texto para resolver novos problemas sobre a escrita. Por outro, sabem que a grafia de uma dada palavra é constante (“sol” terá uma mesma grafia) e aproveitam tal conhecimento também para avançar na produção, não precisando refletir novamente sobre termos que já escreveram. Da mesma maneira, esse conhecimento apóia outra decisão: ao ampliar a 
reflexão sobre as relações sonoras e suas representações, ocupando-se do som final de "sol”, as crianças optaram por acrescentar uma nova letra às duas grafias da palavra; acrescentaram um $\mathrm{O}$ final em "sol”, de "guarda-sol”, e igualmente o fizeram em "sol” de "cadeira de sol".

Quando se posicionam como leitoras da produção, outra preocupação das crianças esteve relacionada à necessidade de buscar informações em palavras já grafadas para produzir novas. Esse procedimento, constantemente explorado nos processos de produção, merece uma análise à parte, visto que as crianças não apenas se pautavam em suas próprias escritas, mas buscavam estabelecer diferentes relações sonoras para a composição de um novo vocábulo.

\subsection{PROCEDIMENTOS DE BUSCA DE INFORMAÇÕES: AS PALAVRAS ESTÁVEIS, AS PALAVRAS DE REFERÊNCIA E AS RELAÇÕES SONORAS}

Uma das mais importantes conquistas a ser feita pelas crianças no processo de apropriação do nosso sistema de representação está ligada ao princípio alfabético. Descobrir que sons podem ser grafados de uma mesma forma, ainda que sirvam para representar palavras de significados completamente diferentes, é uma das chaves para a compreensão da nossa escrita. É uma descoberta gradual e de caráter conceitual, exigindo mais a compreensão do que a informação propriamente dita (a posse da informação, dada por um sujeito experiente, nem sempre é suficiente para a compreensão); trata-se de uma descoberta que as crianças realizam conforme são capazes de conceitualizar, de modo cada vez mais amplo, a alfabeticidade do sistema. Se, no início da construção da escrita, a criança preocupa-se com características do objeto a ser representado, em um dado e crucial momento precisa descobrir que, se há relações a ser estabelecidas, a natureza delas explica-se pela representação sonora.

O princípio alfabético determina que as palavras sejam representadas considerando-se a relação fonema-grafema. Por essa razão, o MA, por exemplo, terá sempre a mesma representação independentemente da palavra da qual fará parte: MAriana, MAçã, MAcaco, caMA, caMArão. Qualquer que seja a palavra e seu significado em nossa língua, a grafia do MA será fixa. Essa compreensão permite que as crianças passem a produzir gradativamente escritas iguais ou muito próximas às convencionais.

A despeito disso, é fato que as relações fonema-grafema não são unívocas em nosso sistema. Um mesmo som pode ter diferentes representações, como é o caso do fonema /s/ das 
palavras CENOURA e SEMENTE, assim como uma letra pode representar diferentes sons, como o “x” em xadrez, táxi e exame.

O princípio ortográfico, que igualmente rege e organiza nossa escrita, significa outra conquista a ser realizada pelos aprendizes, sem deixar de lado a necessidade de identificação de irregularidades ou de escritas aparentemente arbitrárias, para as quais não há uma norma e será preciso memorizar a grafia ou mesmo recorrer a fontes de consulta, como o dicionário.

O procedimento de buscar informações em fontes reconhecidas (como um dicionário) é utilizado por escritores competentes sempre que encontram dúvidas ao escrever. Em vista das especificidades, por se tratar do processo de compreensão da escrita alfabética, as crianças podem também explorar fontes de informação, recorrendo a palavras cuja grafia já dominam ou que lhes é familiar para produzir novas escritas.

O procedimento de apoiar-se em fontes de consulta, praticado por escritores competentes sempre que encontram dúvidas ao escrever, pode ser fundamental também no processo de apropriação do princípio alfabético. As crianças podem utilizar palavras cuja grafia conhecem para produzir novas escritas.

O reconhecimento desse procedimento aparece inclusive em documentos oficiais, que reiteram sua importância. Nos documentos curriculares argentinos, apenas para citar um exemplo, enfatiza-se que: "los niños avanzan hacia una escritura convencional cuando se les proporcionan referencias escritas que les permitan construir sus escrituras apoyándose en ellas”,23. (SECRETARIA DE EDUCACIÓN DE LA CIUDAD DE BUENOS AIRES, 1999, p. 320)

Como foi descrito no Capítulo 3, o trabalho realizado com os nomes próprios na Escola da Vila permite uma série de análises sobre a nossa escrita e ainda favorece o domínio de um repertório de palavras. Tão constantes são as situações que vivenciam e tão sistemáticas as intervenções de seus professores que as crianças passam a identificar o seu nome e o de vários colegas mesmo sem ser capazes de ler convencionalmente. Conforme avançam na conceitualização da escrita, as crianças descobrem que sons iguais podem ser grafados da mesma forma. Com o apoio do professor, inicialmente, passam também a refletir sobre essas palavras que dominam e sua relação com novas grafias. Sempre que há algo a ser escrito e que se possa recorrer aos nomes de crianças da classe, busca-se essa alternativa. Se uma criança precisa

\footnotetext{
23 “As crianças avançam e direção à escrita convencional quando lhes são proporcionadas referências escritas que lhes permitam construir seus escritos apoiando-se nelas”. (Tradução livre - Andréa Luize)
} 
escrever “casaco” para incluir na lista de bagagem do acampamento, os nomes de Caio, Camila ou Carolina podem ser referências úteis. Utilizar os nomes como fontes de informação passa a ser, pouco a pouco, uma tarefa exercida com autonomia pelas crianças.

As classes de Grupo 3 e Grupo 4 possuem, cada qual, uma lista de nomes das crianças da turma, que permanece fixa no mural exatamente para facilitar o uso das palavras estáveis como referência para a escrita. Esse procedimento de consulta vai se tornando mais sofisticado a partir do momento em que as crianças avançam em suas possibilidades de identificar sons similares entre as palavras. Se, no começo, atentam-se, sobretudo, às partes iniciais dos nomes dos amigos, aos poucos vão ampliando as investigações e descobertas que são capazes de fazer, conseguindo, por exemplo, localizar partes que necessitam no meio ou no final. O LI da Carolina também passa a ser buscado como ajuda para se escrever "livro", por exemplo.

Ao utilizar de modo sistemático esse procedimento de consulta nos nomes próprios, as crianças avançam, ainda, realizando tentativas de estabelecer relações sonoras também com outras palavras, não necessariamente presentes como modelos de escrita no ambiente em que se encontram. Enquanto refletem sobre a parte sonora que desejam grafar, buscam, mentalmente, outras palavras em que o mesmo som esteja representado. Descobrem que não apenas os nomes dos colegas são fontes de informação, mas em igual medida outras palavras. As crianças começam a solicitar do professor a escrita de palavras que reconheçam como um importante auxílio para o problema que precisam resolver. Se desejam escrever "fogueira", como palavra integrante de uma legenda da imagem de uma festa junina, recorrem à palavra "folha”, que lhes surge como um modelo possível. Não sabem, porém, grafar tal palavra e requerem o apoio do professor, que a escreve a fim de que realizem a investigação e façam o recorte necessário para produzir o que desejam naquele momento. As relações sonoras passam, portanto, a ser estabelecidas entre quaisquer palavras de seu universo oral. Palavras assim identificadas e sugeridas pelas crianças se constituem em referências para suas escritas.

Para as crianças que atuaram nas situações dessa investigação, é comum em suas classes que, a partir do momento em que o procedimento de consulta e as relações entre partes sonoras se torne algo possível para boa parte dos alunos de um grupo, os professores organizem novas listagens - com nomes de animais que estão sendo pesquisados, brinquedos ou brincadeiras preferidos pelo grupo, personagens de histórias apreciadas - que, acompanhadas de imagens, 
aumentem as alternativas de pesquisas. Esse novo repertório também passa a ser uma outra referência para as produções.

O estabelecimento de relações sonoras a partir das mais variadas fontes - nomes dos amigos do grupo, palavras presentes na sala em que atuaram ou mesmo outras as quais se remetiam - foi amplamente realizado pelas crianças ao longo do processo dos textos propostos nessa investigação.

A lista de nomes do grupo-classe era solicitada constantemente e, por essa razão, passou a fazer parte das situações de escrita. Foram organizadas duas listas, uma para apoiar alunos do Grupo 3 e outra para o Grupo 4, idênticas às que estavam fixadas nos murais das respectivas salas de aula. Tais listas serviam para apoiar escritas em diferentes ocasiões do processo e funcionavam como fontes de informações também por motivos diversos, como se discutirá abaixo. Esse procedimento pôde ser observado em todas as parcerias, com graus variados de possibilidades no estabelecimento de relações entre o que já conhecem e o que precisavam grafar naquele instante.

Percebeu-se que as mesmas palavras estáveis - os nomes - podem ganhar diferentes funções, a depender do momento de conceitualização da escrita vivido pelas crianças. A dupla Beatriz e Luiz, cuja escrita se mostrava bem distante da convencional nas produções iniciais, já reconhecia, como as demais parcerias, a possibilidade de consulta às palavras que dominavam. Embora não estivessem preocupados, em um primeiro momento, com as relações sonoras, essas duas crianças recorriam à lista de nomes dos amigos para encontrar ali um repertório de letras que os ajudasse a compor escritas variando a quantidade e a qualidade de caracteres. Na produção da lista de bagagem de viagem para a praia, Beatriz usou todo o tempo a lista de nomes dos colegas para eleger as letras que iria utilizar. Exerceu essa tarefa aleatoriamente, escolhendo letras presentes em quaisquer nomes, ou ainda copiando alguns deles de forma literal ou invertendo algumas das letras. Nesse caso, fica notório o fato de já identificar tais palavras como escritas corretas em nosso sistema e as letras como partes legítimas para a composição da escrita.

Uma das mais comuns pesquisas às palavras estáveis, porém, ocorria pela necessidade de localizar partes sonoras semelhantes, o que denota um estágio mais avançado de conceitualização da escrita. Ao repetir oralmente a parte sonora - em geral, a sílaba - que precisavam para compor uma dada palavra, nomes dos amigos surgiam como uma possível ajuda, como se evidencia abaixo: 
Daniel: Começa com 3 camisetas...

Flora: Eu sei fazer o 3, mas não sei o resto das letras (diz e faz o 3 na folha, espelhado)

Daniel: Camiseta começa com ca, isso você já sabe...

Flora: Sei, mas não tem nenhuma Camila pra eu copiar...

E: Aqui tem uma lista de nomes das crianças da classe de vocês. Vocês podem usar.

Daniel: Ah, que bom! (olha e rapidamente localiza Camila). Tá aqui.

Flora: (copia corretamente C e A). Mi, mi... É o “mi” da Camila também.

Esse breve diálogo permite a verificação de uma possibilidade de consulta a outras palavras para resolver problemas pontuais. Esse tipo de procedimento também favorece uma maior aproximação à escrita alfabética. Flora e Daniel, por exemplo, quando não recorriam a uma fonte de informações, ainda oscilavam entre usar somente uma letra para cada sílaba ou mais de uma. No caso da sílaba CA, grafaram corretamente por localizarem em CA de Camila uma resposta. Em outras situações de produção, o mesmo CA era grafado somente com C (identificado oralmente como “ca” por essa parceria), conforme se pode observar:

Flora: 4 casacos de lã. Quatro pra cada um. Vou pôr primeiro o quatro.

Daniel: Isso!

Flora: (digita 4) Ca, ca, ca (procura no teclado).

Daniel: É esse aqui, ó! (mostra C) Esse é o ca

Flora: (digita C). Agora, za...

L2/D2

É justamente o domínio progressivo do procedimento e a constante consulta a diferentes fontes que permitem a aproximações em relação à escrita convencional. Outras palavras figuram como solução para os problemas que enfrentam ao ter que tomar decisões sobre suas escritas. E essa coleta de informações avança também em grau de complexidade, servindo não apenas para relações entre sílabas, mas também entre partes sonoras ainda menores, como a representação de fonemas, outro fato recorrente nas situações de produção textual propostas e observadas, como demonstra o seguinte exemplo:

Giulia: Rou-pa

Guilherme: Falta o PA. O P e o A

Giulia: O P? Qual é o P? É de Pedro?

Guilherme: É igual...

Giulia: Escreve Pedro pra mim (dirigindo-se a mim) 
E: Olhem. Aqui tem uma lista dos nomes de todos os amigos da classe, como está no mural da sala de vocês.

Guilherme: Legal!

Giulia: Pedro, Pedro, Pedro... (diz enquanto busca esse nome na lista.) Aqui! (localiza Pedro e copia o P. Depois já coloca $\mathrm{A}$ )

Os nomes dos amigos auxiliaram ainda na resolução de problemas mais complexos do nosso sistema, como as nasalizações. Como grafar o ÃO de “feijão” na parlenda, por exemplo? Esse fonema foi uma dos mais discutidos pelas crianças e, embora tenha sido grafado de modos bastante diferenciados, muitas vezes recebeu a representação convencional diante da relação que puderam estabelecer com palavras já conhecidas:

Guilherme: Começa com um, dois, feijão com arroz.

Giulia: Eu coloco o 1 e o 2 (fala e escreve)

Guilherme: Depois, fê, começa com F

Giulia: (escreve, dando um pequeno espaço entre a letra $\mathrm{F}$ e os algarismos já escritos)... jão, jão...João ajuda...

Guilherme: (procura na lista o nome de João). Tá aqui. Já achei... Mas você vai escrever João?

Giulia: Feijão... João... Feijão... João... (repete várias vezes em voz alta)

Guilherme: Vai escrever João?

Giulia: Só uma parte... A do ão... Onde é a o ão?... João... feijão... (Pará um tempo e fica olhando a grafia de João) Jo-ão, Jo-ão... Aqui (diz apontando o ã e copia ÃO corretamente).

P1/D1

Questões de naturezas diversas foram tematizadas pelas parcerias em virtude do conhecimento que possuíam sobre os nomes enquanto repertório de palavras estáveis. Convenções do nosso sistema, muito mais de caráter ortográfico, também estiveram em pauta, sendo foco de discussões mesmo por crianças que ainda não dominam completamente a escrita alfabética, como se vê na conversa entre Brunno e seu parceiro Antonio:

Antonio: Seis jaquetas! (diz e começa a grafar, agora escrevendo o 6 corretamente)... Seis, jááa... (coloca GA) Brunno: Não. GA forma ga. É já que tem que ser... É J A. Senão vai ficar gaqueta.

Antonio: G A também faz, também dá certo. Ó: Gi-u-li-a Faz gi. O G faz gi com o I e faz já com o A.

Brunno: Mas G A faz ga. Igual Gabriel. Não vai dar pra ler e nem pra entender.

Antonio: Tá. Igual Gabriel vai ficar. Tá. (escreve JA) 
Outras relações sonoras, que poderiam também ser consideradas de caráter mais complexo tendo em vista a pouca experiência escritora das crianças entrevistadas e o não domínio - ou a recente conquista - do princípio alfabético, foram igualmente evidenciadas por algumas duplas. Nesse sentido, por exemplo, consultaram às palavras estáveis - constituídas pelos nomes dos colegas - a fim de identificar o S final para a grafia de plurais, em Mateus, o L final em Daniel para a grafia de “pastel” (nesse caso, a discussão foi pontuada pela possibilidade de uso do L ou do U) e o AN em Daniel e em Antonio para uma nasalização, na escrita de "lanche".

A partir dos exemplos apresentados, pode-se afirmar, primeiramente, que preocupações de ordem ortográfica já são evidenciadas pelas crianças, mesmo antes de mostrarem uma escrita convencional. O conhecimento que têm sobre a língua escrita em geral e as reflexões que são capazes de realizar sobre a grafia das palavras favorecem amplas observações sobre a organização do nosso sistema de representação. Em segundo lugar, buscam, mais uma vez, agora para resolver problemas ortográficos, soluções nas palavras já estabilizadas. O trabalho com os nomes próprios, visto de modo mais amplo, não permite apenas observações e confrontos do ponto de vista da produção alfabética, mas possibilita análises além desse princípio, já voltadas para as normas mais específicas que regem nossa escrita.

Para boa parte das crianças entrevistadas, de fato, já era possível uma análise ainda mais sofisticada, contemplando-se até o uso de outras palavras como fontes de consulta, mesmo que elas não estivessem grafadas em algum portador na sala em que trabalharam. Nesses casos, as duplas solicitavam o apoio da investigadora: pediam que grafasse determinadas palavras que julgavam fundamentais para auxiliar nas decisões que tomariam. No Quadro 6, apenas em caráter de exemplo, seguem alguns desses pedidos de escrita feitos pelas parcerias: 


\section{QUADRO 6 - LISTA DE PALAVRAS USADAS PARA CONSULTA}

RODRIGO (nome do irmão de uma das crianças) - para a escrita de RO de roupa (D1)

VACA - para a escrita de VA em luva (D1)

PAZ - para a escrita de PAS em pastéis (D1)

COMETA - para a escrita de COME em comer (D1)

JOSÉ - para a escrita de É em amarelinho (D6)

GUARDA-ROUPA - para a escrita de GUA em guarda sol (D2)

RAFAEL (nome do irmão de uma das crianças) - para a escrita de RRA em garrafa (D2)

IGUANA - para a escrita de GÜI em lingüiça (D2)

RUSSO - para a escrita de RRO de arroz (D2)

BOLA - para a escrita de BÓ em bóia (D3) e em bota (D2)

GUARÁ - para a escrita de GUA em guaraná e em guarda sol (D7)

TUBO - para a escrita de TU em toalha (D7)

VAN HELSING (personagem caçador de vampiros de um filme) - para a escrita de VÃO em carvão (D2)

Notou-se ainda que, em algumas situações, bastava para as crianças encontrar as referências sonoras, desprezando a necessidade de observação da grafia. Foi dessa forma que muitas duplas identificaram letras ou sílabas: na dupla 2, foi suficiente a referência ao B de Beatriz para a escriba reconhecer a letra a ser utilizada; na dupla 5, Jhoão, o ditante, perguntou para a colega se a lembrança da palavra “Anjinho”, personagem conhecido de histórias em quadrinhos, não serviria para grafar o final de "amarelinho" na parlenda, obtendo uma resposta positiva. Nessas duas situações, e em outras encontradas ao longo das discussões entre as crianças, o diferencial que se estabelece está no fato de que a visualização da palavra grafada já era algo dispensável. Essa possibilidade no uso do procedimento de consulta a palavras foi observada somente entre crianças que já dominavam a escrita alfabética ou estavam bem próximas dessa conquista.

Para finalizar a análise das relações sonoras entre palavras, é preciso tecer um breve comentário sobre o que, efetivamente, conseguiam recortar das palavras identificadas para apoiar a produção de novas grafias. Ainda que as relações estabelecidas entre os sons estivessem corretas, nem sempre as crianças podiam extrair da "palavra de consulta” a parte gráfica 
necessária para a escrita desejada. Isso dependia das possibilidades que tinham de acordo com os conceitos já apropriados acerca da escrita. Somente para citar um exemplo, uma das crianças solicitou a escrita de "guará” para compor "guaraná” e "guarda-sol”. Do ponto de vista sonoro, a relação em pauta se mostra acertada. No entanto, tal criança oscilava ainda entre uma escrita silábica e silábico-alfabética, o que teve como conseqüência o recorte de apenas duas letras (GU) para compor a sílaba GUA. Para ela, duas letras eram mais do que suficientes para a grafia da parte sonora que buscava resolver naquele momento. Em outros casos, também se notou o uso de uma única letra da palavra pesquisada para a composição de sílabas em que havia a necessidade de dois ou mais grafemas.

O procedimento de consulta a outras palavras ocorreu de maneira mais recorrente nas produções feitas com lápis e papel do que no computador, uma vez que o próprio teclado por si só se evidenciou como uma rica fonte de consulta. Ter à sua frente todos os símbolos usados no nosso sistema de escrita foi um importante diferencial que marcou as produções escritas e igualmente os processos de interlocução entre as crianças. É por essa razão que, a partir daqui, serão comentadas, especificamente, as questões que se colocaram como peculiares nas produções feitas no computador.

\subsection{O COMPUTADOR: TAREFAS E REFLEXÕES POSSÍVEIS}

O uso do computador para a elaboração de duas das produções propostas possibilitou atuações diferentes por parte de algumas parcerias. Não somente se constatou um uso mais sistemático do teclado como fonte de informação, como um empenho maior de determinadas crianças na realização da própria tarefa proposta ou em suas tentativas de controle e revisão do texto.

Nos tópicos que se seguem, serão expostas e discutidas justamente essas reflexões, que, nos processos de produção no computador, se tornaram mais amplas ou foram evidenciadas.

\subsubsection{O teclado como fonte de informação}

Assim como as palavras já estabilizadas ou outras utilizadas como referências pelas crianças para novas escritas, também o computador traz uma nova possibilidade de consulta: o teclado. Composto por todo o repertório de letras utilizadas em nosso sistema, foi inúmeras vezes 
usado pelas crianças para solucionar dúvidas sobre a identificação de caracteres. Era comum que a criança ditante mencionasse uma letra ou uma parte sonora cujos grafemas não eram de imediato reconhecidos pelo escriba. Quando escreviam no papel, o recurso mais usual era a procura de outras palavras, ação de extrema importância conforme destacado anteriormente. No entanto, na produção no computador, era no próprio teclado que as crianças buscavam recorrentemente solucionar o problema, como faz a dupla abaixo:

Guilherme: Bo-ta. O ta, agora... o T...

Giulia: Qual é o T?

GUI: É de Tomás.

Giulia: Pega a lista pra eu ver (faz menção à lista de nomes das crianças de sua classe).

Guilherme: Não precisa. Olha o T aqui (indicando o T no teclado). É mais fácil ver aqui.

Giulia: (digita o T conforme indicado pelo colega)

Como afirma Guilherme, identificar as letras no próprio teclado “é mais fácil”, uma vez que todo o repertório está ali presente. A estratégia também se mostrou mais rápida do que buscar a lista de nomes, localizar a grafia de “Tomás” e ali a representação da letra desejada.

A presença do teclado também propiciou a algumas parcerias a ampliação do repertório de letras usadas para compor as grafias manuscritas. Pedro e João, cuja produção já foi citada para exemplificar escritas silábicas, tendiam a utilizar sistematicamente vogais para grafar o que desejavam. Na lista de viagem para a praia, na qual aparecem doze itens no total, somente as consoantes D, V, K, C e R foram aproveitadas na grafia de cinco palavras, conforme se verifica a seguir: 
Produção da lista 1:

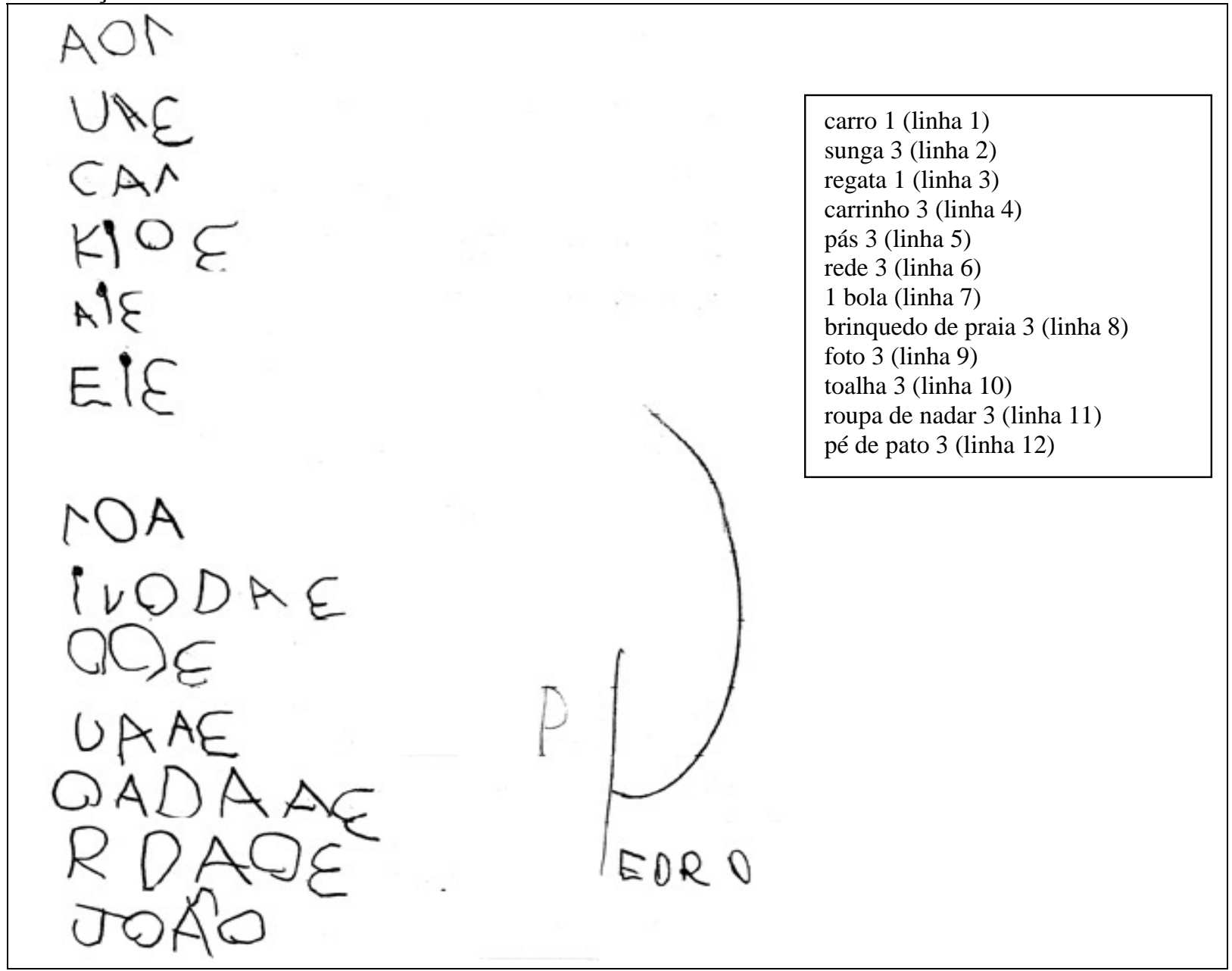

Na lista elaborada no computador, entretanto, a presença de consoantes se amplia consideravelmente, como se observa abaixo:

Produção de lista 2:

\section{OADIO3KUU3OADRV3UAIAODS3AAODSV3IOOO3AI ADOODRV3AADRV3AIADRVAFMAUUO3CRA3UAIA3 EROO1}

roupa de frio 3 capuz 3 bolsa de neve 3 luva de neve 3 sapato de neve 3 binóculos 3 máquinas de foto de neve 3 calça de neve 3 arminha de neve para matar um urso 3 lanterna 3 lupa 3 carro 1 
Comparando ambas as produções, a despeito da diferença quantitativa de palavras entre uma e outra, nota-se que nessa segunda listagem, praticamente em todos os itens grafados as consoantes foram utilizadas. O mesmo se deu na relação entre a parlenda escrita no papel e a escrita no computador. Essa incidência maior de consoantes nas produções no computador também ocorreu nos processos de outras duplas que apresentavam escritas de caráter silábico ou silábico-alfabético.

Além desse aspecto, pode-se atestar que a presença do repertório de letras no teclado atua ainda no sentido oposto, restringindo o uso de símbolos, o que é igualmente favorável no processo de algumas duplas. Crianças no início do processo de apropriação da escrita são propensas a utilizar outros símbolos, denominados usualmente de pseudo-letras, para elaborar suas produções. São tentativas de imitação dos traçados convencionais. Uma das duplas observadas nessa pesquisa incluiu nas escritas sobre o papel símbolos diferenciados, marcando esse tipo de ocorrência. Para essas crianças, como se verá em um exemplo detalhado no capítulo 6, o teclado "ajuda a reconhecer que as letras do alfabeto constituem um conjunto finito". (TEBEROSKY, In: TEBEROSKY; GALLART, 2004, p. 163)

Pode-se tomar ainda outro exemplo em relação à restrição de traçados: a ocorrência dos espelhamentos - inversões - perceptíveis nas produções manuscritas. Embora não se tenha percebido uma relação direta entre esse aspecto e os conceitos sobre a escrita já construídos pelas crianças, tampouco espelhamentos sistemáticos de uma mesma letra, foram encontradas inversões nos seguintes grafemas: C, E, F, J, N, P, S, Z. Trataram-se de casos isolados marcados, muitas vezes, pelo aparecimento da mesma letra, e na mesma produção, grafada ora de modo inverso, ora de modo correto.

Reconhece-se o espelhamento de letras como comum nos processos de algumas crianças em suas tentativas de compreensão do princípio alfabético: são tantas as decisões a tomar na produção de um texto que, por vezes, o traçado correto fica em segundo plano. Outra possibilidade é o espelhamento proposital como um recurso para variar os traçados, especialmente quando se dispõe de um pequeno repertório. Há também em jogo, muitas vezes, uma dificuldade motora em traçar determinadas letras. O uso do computador, porém, garante as letras em seu traçado correto e estas, tão logo digitadas, também passam a compor o texto de maneira legível e servem como modelo. Além disso, no computador, a tarefa de traçar pode ser deixada de lado em prol das demais ações que envolvem a produção de um texto, uma opção que, 
pedagogicamente, pode ser conveniente em determinados momentos (quando for o caso de centrar a atenção da criança mais no como escrever do que no como traçar as letras).

A legibilidade das produções elaboradas no computador trouxe outras vantagens, entre as quais a participação mais ativa de ambas as crianças das parcerias nas decisões sobre o modo como grafar as palavras, aspecto que será abordado no próximo tópico.

\subsubsection{O computador ampliando as interações entre a dupla}

Como foi analisado anteriormente, a interação entre as crianças da dupla deu-se de maneiras bastante diversas nas diferentes produções propostas. Inúmeras funções em relação à composição do texto foram exercidas pelas crianças, que intercalavam, por vezes, os papéis de ditante e escriba em função da necessidade de tomar decisões.

Nas tarefas em que o computador era o recurso de produção, entretanto, evidenciou-se sistematicamente uma participação mais ampla do ditante a respeito das decisões sobre os aspectos notacionais. Da mesma forma, observaram-se mais tentativas de revisão nas grafias realizadas durante a produção da palavra.

O computador oferece inúmeras vantagens para a elaboração de textos em parceria, se comparado às possibilidades da produção manuscrita. Em primeiro lugar, o computador exibe de forma nítida todos os símbolos que compõem nosso sistema, incluindo letras e outras marcas gráficas utilizadas para a pontuação e acentuação. Esse repertório fica evidente para quem grafa e também para quem dita, favorecendo amplas observações e até a divisão da tarefa de digitar.

Em segundo lugar, o monitor também desponta como um diferencial na produção no computador. O texto ganha em nitidez e legibilidade para ditante e escriba. Na grafia manuscrita, ao contrário, o traçado da letra e a própria posição do papel, para facilitar a tarefa de quem escreve, dificulta o acompanhamento da produção do texto por parte de quem o dita. Muitas vezes, nessa pesquisa, a criança responsável por ditar apenas via o texto quando o trazia para perto de si e, em geral, somente depois de finalizada a escrita de uma palavra. A possibilidade de averiguar as ações do escriba pelo monitor ampliou a participação do ditante e também a qualidade das intervenções dos sujeitos que exerceram esse papel. Do mesmo modo, a possibilidade de correções aumenta pelo acompanhamento constante do que está sendo produzido. Como sugere Teberosky (In: TEBEROSKY; GALLART, 2004, p. 163), “a 
apresentação do texto sobre a tela [...] é percebida pela criança como algo mais objetivo e distanciado dela própria, e é mais fácil que seja objeto de correção”.

Além desses aspectos, é preciso valorizar o fator motivação. Escrever no computador é, para as crianças, algo ainda mais próximo ao mundo adulto e influi diretamente na disponibilidade para interagir com esse recurso: o contexto da informática, por si só, parece atrair o público infantil.

A participação ativa da dupla de escritores foi mesmo marcante nas produções feitas no computador, em se tratando dos aspectos atrelados à notação. A interação entre a parceria ampliou-se de maneira significativa no caso de todas as duplas e fomentou, inclusive, reflexões diferenciadas referentes à escrita, não explicitadas nos processos de elaboração dos textos manuscritos, entre as quais a necessidade de segmentação entre as palavras. Também no que concerne a esse aspecto (a interação), serão trazidos exemplos mais precisos no decorrer do próximo capítulo, especialmente nos comentários sobre os processos interlocutivos da dupla Beatriz e Luiz.

Além de permitir uma atuação mais efetiva dos sujeitos-escritores, o computador impõe a necessidade de um procedimento de análise muito preciso: se as letras e símbolos estão à disposição dos pequenos escritores, resta, a cada momento, analisar e selecionar os que farão parte do texto. Possivelmente por essa razão, o uso de marcas gráficas, bem como das letras e as tentativas de segmentação entre as palavras, foram observados na elaboração dos textos no computador e merecem um destaque nessa investigação.

5.4.3. Além do princípio alfabético: a segmentação e o uso de outras marcas gráficas

A compreensão do princípio alfabético que rege nosso sistema de escrita decorre de um longo processo de reflexão e de numerosas hipóteses conceituais construídas pelos aprendizes. Além desse princípio, outras regras devem ser igualmente observadas e apropriadas, entre as quais a segmentação entre palavras em um texto e o emprego de outras marcas gráficas, visto que não apenas letras compõem o repertório de símbolos desse sistema, mas também acentos e sinais de pontuação.

É fato que, de modo geral, só depois de escreverem alfabeticamente as crianças passam a se ocupar do uso dessas convenções em seus textos, o que precisa ser avaliado do ponto de vista 
da intervenção pedagógica. Ferreiro e Teberosky (1999, p. 282) destacam que "somente quando se compreende a forma de produção de escritas própria ao sistema alfabético, pode-se abordar problemas de ortografia”. Mas não se pode negar que a experiência vivenciada pelas crianças com o universo letrado à sua volta favorece observações de diferentes naturezas, inclusive permitindo que reconheçam a existência de símbolos diferentes das letras e percebam a impossibilidade de se aglutinar todas as palavras de um texto. Essa experiência faz com que, muitas vezes, as crianças criem hipóteses também atentando para a segmentação e o uso de acentos, por exemplo, antes mesmo de terem se apropriado da escrita alfabética. Não se está afirmando, aqui, que esses pequenos aprendizes tenham compreendido as convenções atreladas à acentuação ou mesmo que dêem conta da correta separação entre as palavras. O que fazem é empreender tentativas, experimentando acentuar palavras ou mesmo considerando certas separações entre trechos do texto. Foi o que se pôde notar nos processos de produção de algumas das duplas que participaram da presente investigação, principalmente ao lidar com o computador, aspectos que serão detalhados a partir desse ponto.

\subsubsection{A segmentação}

A segmentação das palavras foi um dos desafios enfrentados por alguns dos aprendizes iniciantes selecionados para essa pesquisa, ainda ocupados em compreender o princípio alfabético. Marca da linguagem escrita, a separação necessária entre palavras em um texto é uma tarefa complexa para as crianças. Em primeiro lugar, pela relação entre a ação de segmentar e a própria concepção de palavra que precisam construir.

A idéia de "palavra” gera entre lingüistas, até hoje, diferentes acepções. Depois de discorrer sobre algumas delas, Ferreiro e Pontecorvo propõem uma concepção prática, apta a auxiliar os professores na compreensão dessa questão:

Dizemos que ao escrever separamos as palavras. Seria mais adequado dizer que a escrita define a unidade "palavra", já que a escrita nos oferece a melhor definição prática (não teórica) de "palavra": conjunto de letras separadas por espaços em branco. [...]

Portanto, a escrita, ao introduzir brancos entre as seqüências de letras, contribui de maneira notável ao isolar, para o leitor, as unidades de significado ou aquelas que, sem ter significado próprio definido, afetam o significado dos grupos nominais ou verbais. (In: FERREIRO; et al., 1996, p. 40 e 41. grifos das autoras) 
Importante também salientar o surgimento tardio da segmentação de palavras no texto, quando se analisa o processo de construção da escrita vivido pela humanidade:

[...] durante um longuíssimo período na história da cultura ocidental, a tarefa de separar o texto em palavras (e, eventualmente introduzir a pontuação) era tarefa do leitor, não do autor intelectual nem do copista. A separação sistemática das palavras é uma aquisição medieval (junto com outros recursos de organização gráfica textual). (FERREIRO; PONTECORVO In: FERREIRO; et al., 1996, p. 39 , grifo das autoras)

Para as crianças em processo inicial de apropriação da escrita alfabética, a idéia de palavra é, muitas vezes, incipiente, não permitindo que a segmentação seja, de maneira efetiva, uma preocupação nas situações de produção textual, sobretudo nas primeiras versões de um texto. Isso faz com que se possa encontrar, na maior parte das vezes, escritas contínuas cujas separações são delineadas pela necessária mudança de linha, seja ao término da mesma, seja em virtude da estrutura usual do tipo de texto que se produz (nas listas elaboradas no papel, por exemplo, cada item foi separado do anterior pela mudança de linha, marcando a enumeração que caracteriza essa estrutura).

Em segundo lugar, a ausência de separação entre as palavras em um texto infantil pode ter como causa o uso da letra bastão (denominação freqüentemente atribuída à letra de imprensa maiúscula). Reconhecido como favorável para as reflexões e observações que levem à compreensão do sistema alfabético, o uso de caracteres separados propicia uma análise do traçado diferenciado dos símbolos e um controle quantitativo e qualitativo dessas marcas gráficas na produção. Todavia, pela própria separação entre um símbolo e outro, a letra bastão não evidencia a observação de uma segunda separação importante: entre as palavras. Ferreiro e Pontecorvo (In: FERREIRO; et al. 1996, p. 51) pontuam, nesse sentido, que:

Quando a criança começa a trabalhar sobre o "ortográfico dentro do alfabético", um dos aspectos a que deve atender é a definição de palavra que a escritura impõe. É nesse momento que, do ponto de vista da produção, as relações se invertem, e a produção da escrita ligada apresenta vantagens com respeito à escrita com caracteres separados.

Pelas razões até aqui explicitadas, é comum a escrita sem qualquer segmentação nos textos de crianças que não apresentam uma produção alfabética ou que fizeram essa conquista recentemente. Tal fato pôde ser confirmado nas diferentes produções analisadas nesta 
investigação, as quais, em sua maioria, são caracterizadas pela aglutinação das palavras, exceção apenas às listas cuja própria estrutura favorece o isolamento de itens por linhas.

Por outro lado, notou-se em algumas duplas tentativas sistemáticas e assistemáticas de segmentação nas tarefas de produção no computador. Os textos e processos de uma das parcerias, Brunno e Antonio, servirão como exemplo para discutir esse aspecto. A dupla já foi citada no capítulo 4 (item 4.2.2.3, p. 92) por ter entregue a lista elaborada no computador e seus itens separados por hífens. O mesmo recurso foi utilizado na produção de uma das parlendas:

Produção da parlenda 2:

\section{A-GALI-NA-DUVIZI-NHO-BOTAOVOAMARÉLISNHO--} -1-2-3-4-5-6-7-8-9-10-ANTONIO-BRUNNO

a-gali-nha-dovizi-nho-botaovoamarelinho-- (linha 1)

- 1-2-3-4-5-6-7-8-9- 10-Antonio-Brunno (linha 2)

P2/D6

Aqui, tem-se um diferencial importante em relação às razões da separação, não mais atreladas à estrutura do texto, como justificado no capítulo anterior. Na parlenda acima, Brunno e Antonio fizeram, de início, uma tentativa de separação de unidades menores do que os versos da parlenda. Quando segmentam “a-gali-nha-dovizi-nho” (trecho da linha 1), não estão analisando os versos tradicionais e memorizados da parlenda, mas outras unidades, talvez em uma tentativa de aproximação à idéia de palavra ou até de sílaba, e provavelmente de também recuperar o ritmo de oralidade próprio da recitação. Levando-se em conta o momento de conceitualização vivido por tais crianças, a intenção de recortar sonoramente a palavra em sílabas para tomar decisões sobre sua grafia é de fundamental importância por gerar novas reflexões sobre o funcionamento da escrita.

O uso do hífen surge como uma possibilidade de segmentação também em produções de outras duplas. A tarefa de segmentar um texto em palavras é bastante árdua, inclusive pelo fato de que não há, nas regras do nosso sistema, uma marca gráfica a ser usada; trata-se apenas de um espaço em branco, um "nada” a delimitar as palavras no papel. O hífen aparece de modo recorrente em textos escritos na nossa Língua, definindo palavras compostas, ênclises ou marcando separações entre as sílabas de um vocábulo ao final da linha no texto. Sua função de 
separar certas palavras foi generalizada por essa dupla de aprendizes e o hífen foi utilizado sempre que julgavam importante segmentar trechos do texto, conforme as próprias crianças explicitam:

Antonio: Bota 10 (digita 10). Agora os nomes. (começa a digitar seu nome aglutinado ao algarismo zero).

Brunno: Não, não! Tem que apagar. Não pode ficar grudado. Põe o tracinho, senão fica dezantonio.

Antonio: (apaga as letras AN e as refaz, antes digitando o hífen, resultando nesta grafia: 10-ANTONIO)

Brunno: (troca de lugar com o colega, digita o hífen e coloca seu nome: 10-ANTONIO-BRUNNO)

P2/D6

Vale ressaltar que, para a dupla acima, somente no computador essas separações precisavam ser feitas, conforme chegaram a comentar:

Antonio: Primeiro põe nomes. Começa com nossos nomes... Tem tracinho?... Sabe, ele gostar de colocar tracinhos para separar e eu também. Eu tô aprendendo.

Brunno: Mas só no computador. Eu só sei usar o tracinho quando a gente escreve no computador.

E: Por que só no computador?

Brunno: Porque fica fácil, fica beeem mais fácil.

Outros exemplos de produções de crianças elaboradas no computador evidenciam tentativas de segmentação similares às apresentadas, inclusive sem o uso de hífens, como no caso do texto de Giulia e Guilherme:

Produção da parlenda 2:

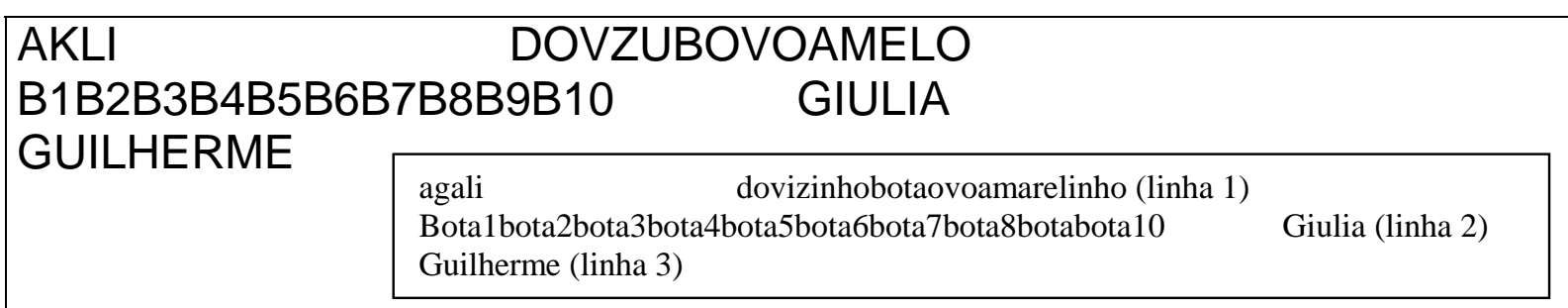

$\mathrm{P} 2 / \mathrm{D} 1$

Como já se destacou anteriormente, a produção de textos no computador exibe uma série de diferenciais em comparação à produção manuscrita. No caso da segmentação, de acordo com 
o que se observou nessa pesquisa, também traz certas vantagens. Pele legibilidade que ganha, o texto no computador se parece muito mais com os que circulam socialmente - em livros, jornais, propagandas etc. - e, como tais, não tem uma escrita aglutinada. Por vezes, como no caso de Giulia e Guilherme, as crianças seguem elaborando o texto sem a preocupação em segmentar. Mas ao verem o texto no monitor, incomodam-se com as longas seqüências de letras que acabam por compor e fazem algumas tentativas de separação.

Outro fator inerente à escrita no computador está na presença de uma tecla - a barra de espaço - especialmente destinada à tarefa de distanciar um caracter de outro. Quando produzem usando o teclado, a ação de segmentar se concretiza no procedimento de apertar uma tecla, diferente do que ocorre no texto manuscrito, situação na qual a mesma tarefa depende apenas dos movimentos da mão.

A explicação dada por Brunno, já citada, sobre as razões que o levam a experimentar segmentações no computador resume as vantagens desse recurso como favorecedor de reflexões sobre esse tema: "é mais fácil”. A produção no computador gerou ainda outras discussões e experimentações por parte dos aprendizes observados, entre elas o uso de acentos, conforme se discutirá no próximo tópico.

\subsubsection{Outras marcas gráficas: os acentos}

A presença de outros símbolos em nossa escrita também é algo passível de observação por parte das crianças. Ao se deparar com os textos escritos, elas podem notar que, além das letras, outras marcas gráficas, como sinais de pontuação e acentos, fazem parte da escrita. Como usuárias do nosso sistema de escrita, são capazes de criar hipóteses e realizar inúmeras tentativas de utilizar tais marcas, assim como fazem para compreender outros aspectos desse sistema de representação.

No caso das produções analisadas, não se identificou o uso de sinais de pontuação, possivelmente porque as listas e parlendas favoreciam menos tal observação. Entre as crianças, tendem a ser mais comuns tentativas de utilizar sinais com funções muito precisas e marcantes, como interrogação para perguntas e ponto final no término da elaboração de um texto de criação. Embora possamos classificar as listas produzidas também como textos de criação, sua estrutura não demanda qualquer pontuação. As parlendas, por sua vez, eram textos memorizados e não se notou experimentações em relação à pontuação nesses textos. 
Já o uso de acentos foi observado com certa constância nas produções das crianças, principalmente para diferenciar os sons abertos e fechados das vogais ou mesmo marcando nasalizações, como nas palavras abaixo:

\section{QUADRO 7 - EXEMPLOS DE PALAVRAS ACENTUADAS}

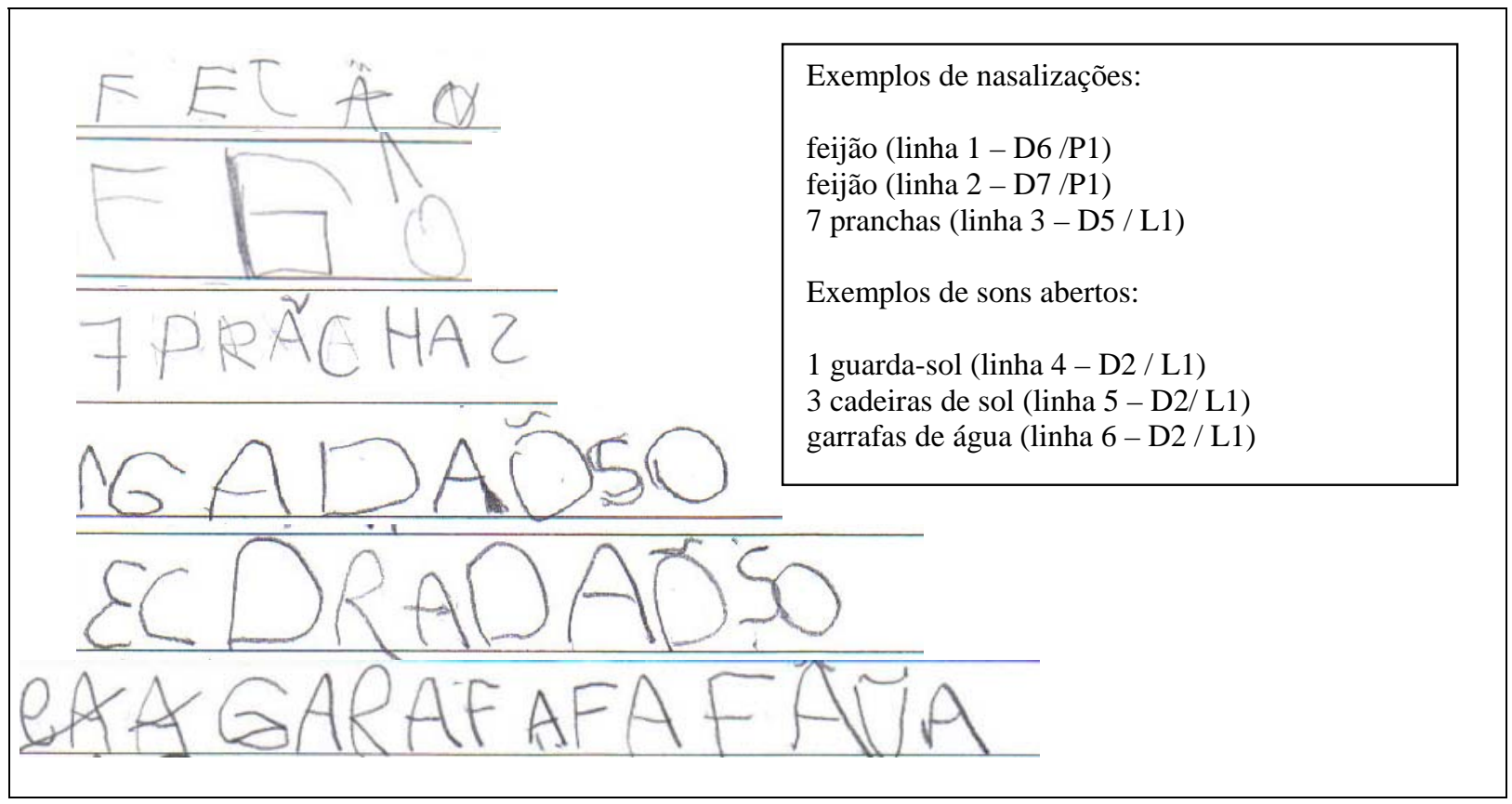

No caso das nasalizações, como já se destacou anteriormente, o reconhecimento do nome João era uma referência também ao uso desse acento em palavras que tivessem a mesma sonoridade, como "feijão”, exemplificado acima. Há ainda as tentativas de marcar sons abertos, mesmo que nem sempre os sinais convencionais sejam usados com esse propósito. É o que se observa nas grafias de "guarda-sol”, “cadeira de sol” e "garrafas de água”, onde o til define a sonoridade.

As produções no computador também exigiram reflexões diferenciadas por parte das crianças no que se refere aos acentos. Uma das duplas que não se ocupou da acentuação nos textos manuscritos passou a fazê-lo no computador, justamente para diferenciar sons abertos, como se verifica nos exemplos: 
Trecho da lista 2:

\begin{tabular}{|l|l|}
\hline HZÁO4 & \multicolumn{2}{|l|}{$\begin{array}{l}\text { agasalho (linha 1) } \\
\text { CIÓU9ecol (linha 2) } \\
\text { NÓOPACAO10 }\end{array}$} \\
\hline
\end{tabular}

A escrita no computador também ofereceu, a outra parceria preocupada com a acentuação, certas dificuldades. Na dupla 2, Flora (mais do que o parceiro Daniel), no papel de escriba, mostrou intensa necessidade de acentuar algumas vogais abertas, mas utilizando o til. Nas produções elaboradas no papel, esse acento era usado recorrentemente, conforme se observa nas escritas apresentadas no último quadro. Porém, ao realizar essa tentativa no computador, as configurações do programa Word impediam o uso desse mesmo acento em todas as vogais, trazendo para a dupla um grande impasse, como no processo de elaboração da parlenda:

Daniel: Bota ovo amarelinho... amarelinho... Escreve amarelo. É o ma.

Flora: Não. É o A... (digita)

Daniel: Ma...

Flora: (digita M A)

Daniel: A-ma-lé...lé

Flora: Não, é a-ma-ré, amaré...

Daniel: a-ma-lé... a-ma-ré... (ri)

Flora: É o R e o E com uma minhoquinha. R e o E.

D: De novo uma minhoquinha?

Flora: É pra fazer É...(ela digita D e tenta o til e o E resultando nessa escrita R E). Ai, de novo! Por que ele (referindo-se ao computador) não quer, heim? Sabe, é bem mais fácil no papel do que no

computador!

Daniel: Não é. É que se ele (refere-se ao computador) não deixa é porque tá errado. Eu acho que só dá no

O e no A, porque nesses dá tudo certo. Vê se não tem outro...

Flora: Outro?

Daniel: Outro desses, que fica nas letras...

Flora: Não entendi.

Daniel: Ai, eu não sei explicar...Me ajuda... (dirigiu-se a mim)

E: Você sugere que a Flora procure outro sinal para colocar sobre a letra, é isso?

Daniel: É.

Flora: Ah! (procura outro sinal no teclado e mostra a tecla com os acentos agudo e grave ). Pode ser essa... Como faz pra colocar? (dirigiu-se a mim)

E: Aperta essa tecla e o $\mathrm{E}$ depois ( $\mathrm{F}$ faz dessa forma)

Daniel: É. Essa tem no nome do meu primo Léo. Mas aí você vai pôr um acento no lugar da minhoquinha... 
Flora: (digita o acento e o E, resultando em É). Mas precisou, porque a minhoquinha não dava e tinha que ter...

$\mathrm{P} 2 / \mathrm{D} 2$

Depois de algumas tentativas de colocação do til sobre as letras E e U, essa dupla solucionou o impasse e Flora descobrindo outras possibilidades de acentuação. Nas vezes anteriores, a opção foi deixar de lado o acento, algo que a incomodava bastante. O computador, nesse caso, por restringir uma opção de acentuação usada com regularidade na produção manuscrita, acabou por expandir o universo de possibilidades dessa dupla, justamente por exibir no teclado todos os sinais utilizados para marcar sonorizações em nosso sistema.

Ainda que não dominem todas as convenções do sistema de representação e sequer grafem de modo alfabético, essas e outras crianças revelam-se capazes de observar e de se preocupar com certas características peculiares da nossa escrita. O que, em geral, só será fruto de intensa investigação em estágios mais avançados da escolaridade, sobretudo no caso da acentuação, que já lhes é passível de observação muito antes. Assim como ocorre com o princípio alfabético, hipóteses são construídas por esses aprendizes em suas incessantes buscas de conhecer e se comunicar por escrito, também considerando os espaços em branco e a presença de sinais diferentes das letras nos textos que circulam socialmente.

5.4.4. Números e letras: dois sistemas notacionais na produção de textos

Todas as produções propostas nesta investigação envolviam a presença de dois sistemas diferenciados: o sistema de escrita e o sistema numérico. No caso das listas, os números tinham como função explícita marcar quantidades; o mesmo se pode dizer da segunda parlenda, referindo-se à quantidade de ovos que coloca a galinha. Já na primeira parlenda, a numeração apresenta a seqüência de versos e atua na composição das rimas, se analisarmos a forma como devem ser falados os numerais: dois para rimar com arroz; quatro para rimar com prato e assim por diante.

Nas consignas dadas para as crianças, não houve orientações sobre como os números poderiam ser registrados (com numerais ou por extenso). Entretanto, a opção da escrita por extenso não foi utilizada pelas crianças. Somente uma pesquisa mais específica sobre o tema (escrita alfabética e notação numérica) poderia dar conta das especificidades do processo desses registros comparativamente. Mas pode-se afirmar que, nas diferentes produções, nenhuma 
criança apresentou resistência ao uso desses dois sistemas na elaboração textual ou mesmo questionou sua pertinência. Também aqui parece que as experiências com o mundo da escrita, em que números e letras podem coexistir em um mesmo texto, contribuíram para a compreensão desse aspecto.

Nos textos manuscritos, a inversão no traçado dos números foi uma constante, especialmente no uso dos algarismos 2, 3, 6 e 7. Como no caso das letras, muitas explicações poderiam ser dadas para tal ocorrência: ausência de preocupação com o traçado correto, em virtude de outras demandas; confusão entre o traçado de letras e números que, por vezes, muito se assemelham (3 e E, por exemplo); a própria dificuldade, comum nessa faixa etária, em discriminar a lateralidade; e a intenção de variar o traçado a depender da função que exerce em um dado contexto: na representação com propósitos específicos (quantidades, números de telefone etc.) ou na composição de outros valores (um três grafado corretamente quando para representar essa quantidade e grafado de modo espelhado na representação de trinta). Sobre esse aspecto, em especial, pode-se consultar as pesquisas de Mónica Alvarado (Cf. FERREIRO; ALVARADO, 2002).

No caso dos espelhamentos, assim como com as letras, também o computador atuou como fonte de informação, visto impedir traçados não convencionais.

\subsection{ALGUMAS CONSIDERAÇÕES}

O propósito do capítulo que aqui se encerra era destacar processos de reflexões vivenciados pelos aprendizes acerca do nosso sistema de representação e todas as suas peculiaridades. Conforme se verificou nos tópicos iniciais, boa parte dos textos não foi composta alfabeticamente, mas sim a partir dos diferentes conhecimentos conceituais já apropriados pelas crianças, aspecto amplamente tematizado nas pesquisas que deram origem ao livro "Psicogênese da Língua Escrita” (FERREIRO; TEBEROSKY, 1999).

A possibilidade de atuar em parceria foi bastante rica também no caso das decisões sobre os aspectos notacionais da escrita. Pequenos conflitos se estabeleciam de modo que cada uma das crianças precisava buscar justificativas para tecer suas argumentações e, igualmente, ponderar as razões apresentadas pelo colega. Chegar a consensos gera momentos de impasse bastante importantes para a reflexão, a análise, o confronto e a ampliação de seus saberes sobre a escrita convencional. 
A produção de textos com o uso de dois recursos diferenciados, o papel e o lápis e o computador, mostrou-se bastante favorável para que problemas também de naturezas diversas fossem vivenciados e resolvidos pelas crianças observadas. Além de possibilitar uma maior interação entre os sujeitos-autores, o computador imprime, de fato, uma grande legibilidade ao texto e, ao mesmo tempo, o distancia de seu escritor, permitindo revisões mais apuradas e durante a produção. O monitor traz o texto para a frente dos autores, outro aspecto interessante, pois escriba e ditante podem acompanhar melhor sua composição.

Acrescida a esses fatores está a possibilidade das crianças observarem sua produção escrita de maneira similar aos textos que circulam socialmente, com letras traçadas com nitidez, o que permite, por exemplo, desestabilizações em relação à escrita contínua, sem qualquer segmentação. A presença de um extenso universo de possibilidades de símbolos no teclado também tende a favorecer a observação dos traçados corretos e o emprego de outros símbolos (letras, numerais ou acentos), aumentando o repertório dos que são usualmente utilizados nas produções manuscritas.

Isso não quer dizer que o computador seja o responsável pelas hipóteses que criam os aprendizes acerca das separações entre as palavras ou mesmo por seus avanços conceituais. Certamente, as observações e experimentações detalhadas nos últimos tópicos se evidenciariam em algum momento do processo, vivido por essas crianças, de apropriação das regras do sistema de escrita. Pode-se afirmar, entretanto, que o computador oportuniza determinados desafios e análises, facilitando reflexões menos comuns na produção manuscrita.

É certo também que papel ou computador não são os responsáveis pela aprendizagem da escrita convencional ou de qualquer outra regra do nosso sistema. As amplas e variadas situações de interação com a escrita e com os colegas é que implicam processos de análise e reflexão sobre os aspectos notacionais. São processos muito particulares de construção da escrita e de compreensão dos propósitos e dos modos de escrever ao se comunicar.

Neste capítulo e no anterior, buscou-se identificar os aspectos mais recorrentes apresentados pelas crianças em suas tomadas de decisões para compor os textos. Reconhecida a importância dessas regularidades, para apoiar as intervenções do professor, não se pode deixar de lado o fato de que cada criança trilha um percurso muito singular para entender o mundo letrado que a circunda. Para ilustrar essa afirmação, o capítulo 6 revelará dois percursos bastante diferenciados, destacando os processos de produção vividos por duas duplas: Camila e Jhoão e 
Beatriz e Luiz. As duas meninas, ambas escribas, explicitaram avanços conceituais bastante significativos no período de produção dos textos (seis semanas aproximadamente), em parceria com seus colegas e estabelecendo com eles interações de naturezas muito específicas. Percursos diversos, descobertas diferentes, ajudas variadas, conhecimentos de extrema importância para pesquisadores e educadores em suas tentativas de compreender e intervir nos processos de aprendizagem da escrita. 


\title{
6 OS PROCESSOS SINGULARES DE APROPRIAÇÃO DA ESCRITA: ESTUDOS DE CASO
}

\author{
Negar a heterogeneidade e buscar a \\ homogeneidade é querer aproximar-se \\ de um modelo, quer dizer, de um padrão \\ socialmente consensual [...] \\ Então, vê-se a diversidade nos modos \\ de ser das crianças como um problema \\ que deve ser superado muito mais \\ do que como uma vantagem que pode \\ ser explorada.
}

(FERREIRO, 2001a, p. 110)

Até este capítulo, discutiu-se as regularidades presenciadas ao longo dos processos de produção textual vivenciados pelas duplas de escritores-aprendizes. Identificar regularidades permite a pesquisadores e professores um olhar mais amplo em relação aos processos de construção de conhecimentos.

A partir do que se apresentou nos capítulos 4 e 5, é possível afirmar que as crianças, apesar de não dominarem o princípio alfabético, são capazes de refletir e criar hipóteses também acerca de outras regras do nosso sistema de representação, bem como de explicitar saberes sobre as funções e propósitos que os atos sociais de escrita evidenciam. Colocam-se, desde cedo, como escritoras habilitadas a enfrentar boa parte das demandas que a produção textual lhes impõe, mesmo que não as solucionem de modo convencional.

A identificação de regularidades nos processos de aprendizagem não significa, porém, a constatação de percursos homogêneos entre os aprendizes. Ao se considerar que "aprender algo equivale a elaborar uma representação pessoal do conteúdo objeto de aprendizagem” (MAURI In: COLL et al., 1998, p. 87 e 88, grifos da autora) e que o sujeito estabelece relações diversas com o que sabe e com suas experiências para atribuir significado ao que é novo, se reconhece a existência de percursos singulares por meio dos quais os aprendizes constroem conhecimentos.

Não se pode negar a relevância das instâncias coletivas de aprendizagem e a importância das interações com outros sujeitos; é nesse ambiente interativo que se criam contextos favoráveis para a particular atividade mental do sujeito e para novas aprendizagens. O processo de construção de conhecimentos é pessoal, mas não entendido como isolado e solitário: a atuação de 
parceiros e do professor configura-se, por esse motivo, absolutamente fundamental para a aprendizagem. Seja na promoção de atividades significativas, seja na mediação das parcerias, o papel do professor será sempre o de oferecer aos alunos as ajudas necessárias.

Inexiste um aprendiz-padrão e, portanto, cada criança, ao trilhar seu caminho nas tentativas de compreender um objeto de conhecimento, construído social e historicamente, dá passos particulares, em tempos próprios e, por vezes, de modo também singular. No caso da apropriação da escrita, já se compreendeu as regularidades na construção conceitual a ser feita, aspecto que vem sendo foco de intensas pesquisas. O reconhecimento da apropriação da escrita e dos diferentes momentos conceituais que a caracterizam, a partir de marcas regulares ou de procedimentos típicos, não implica desconsiderar o caráter ativo e pessoal da aprendizagem. De modo definitivo, os momentos conceituais de compreensão do princípio alfabético, identificados psicogeneticamente, e toda uma gama de saberes direta ou indiretamente relacionados a eles, não são vivenciados e apropriados de forma similar e simultânea pelos aprendizes.

Para a Didática da Língua, é essencial o conhecimento de regularidades que marcam a aprendizagem da escrita - é só desse modo que se poderá, até, falar na construção de uma didática -, mas não se pode querer que todas as crianças dêem os mesmos passos nos mesmos momentos e pelos mesmos caminhos. Experimentar uma dada situação escolar em relação à escrita resulta na elaboração de representações singulares por parte dos alunos; eles não estabelecem as mesmas relações e não atribuem igual significado a cada experiência.

Sob a ótica construtivista, os estudos sobre a leitura e a escrita - desenvolvidos pela Didática, pela Lingüística ou pela Psicologia - não trarão contribuições se investirem em técnicas e respostas prontas, e únicas, para o fazer docente. Como destaca Nunes (In: ALENCAR, 1995, p. 15):

Ler e escrever são atividades complexas que envolvem diversos níveis e tipos de atividade por parte do sujeito. A análise psicológica desses processos não pode, pois, ser simples. Há ainda controvérsias entre pesquisadores sobre o que é central e o que é acidental nos processos de leitura e escrita. [...] Formar uma noção consistente sobre a leitura e escrita é um ponto de partida para o delineamento de novas práticas pedagógicas e aplicações da psicologia à educação, as quais serão reformuladas à medida que os conhecimentos sobre esses processos forem mais profundos e mais amplos. 
Compreender melhor os processos de apropriação da leitura e da escrita, também considerados pelo viés das singularidades dos sujeitos aprendizes, pode certamente ampliar os referenciais para que sejam tomadas decisões de caráter docente na prática de ensino desses objetos de conhecimento.

As situações de produção textual propostas na presente investigação, entendidas como experiências vividas pelos sujeitos-escritores, não só promoveram a observação das tendências apresentadas, mas também de passos bastante singulares. As interações aqui favorecidas acarretaram processos diferenciados, pautados tanto pela relação com a tarefa imposta como pelos conhecimentos já assimilados pelo aprendiz, ou ainda pela relação com o outro, o parceiro na composição do texto.

Ao professor cabe oferecer a ajuda necessária para cada aluno e sua mediação só resultará relevante se puder incidir, de fato, nas respectivas demandas. Como ressalta Mauri (In: COLL; et al., 1998, p. 99),

[...] os professores serão obrigados a concretizar a ajuda prestada aos diferentes alunos e alunas de um modo muito diferente: em um caso deverão ampliar a informação oferecida; em outro, melhorar a organização dessa informação; em outro, continuar oferecendo-lhes contra-exemplos ou a possibilidade de imitar um modelo etc.

Conhecer e acompanhar os percursos singulares dos alunos possibilita uma mediação mais favorável do professor, para que este possa auxiliá-los a significar e ressignificar seus saberes, avançando na compreensão das representações culturais. Justamente pela importância de se reconhecer que os processos dos alunos são únicos, e para despertar ainda mais o olhar de professores e investigadores para o tema, é que, neste capítulo, se pretende discutir as interações entre duas duplas de escritores, evidenciando-se os percursos particulares das escribas que atuaram nessas parcerias. Camila e Beatriz, respectivamente elaborando os textos com Jhoão e Luiz, explicitaram avanços bastante significativos em seus processos de compreensão da escrita, mas, pontuados por interações e percursos bem diferenciados. Essas duas crianças serão, aqui, representativas da diversidade e da singularidade de relações que os aprendizes são capazes de estabelecer e, ao mesmo tempo, da importância de participarem, para aprender, de múltiplas experiências interativas com outros aprendizes e com o objeto de conhecimento em questão: a escrita. 
Os casos analisados a partir do próximo item visam a explicitar os processos cognitivo e interacional nos percursos de produção dessas parcerias.

\subsection{O PERCURSO DE CAMILA}

Camila (4/6.7) e Jhoão (4/6.6) protagonizaram, desde a primeira situação de produção, uma parceria bastante diferenciada se comparada às demais. Camila, enquanto escriba, tomava todas as decisões sobre a grafia das palavras e organização do texto, em geral sem consultar seu colega. Sua produção se caracteriza como silábico-alfabética e algumas trocas e omissões são, por essa razão, marcas de sua escrita. Ao grafar as palavras, silabava em um tom baixo de voz, muito mais para que ela mesma pudesse controlar sua escrita; ouvir as partes sonoras que precisava representar era um apoio importante para eleger as letras que julgava necessárias.

Jhoão, por sua vez, não apenas decidia o conteúdo e ditava os itens para a amiga, como também controlava e avaliava a escrita das palavras. Essa criança, já com intensas preocupações alfabéticas, localizava boa parte das trocas e omissões de letras na produção de Camila. Sua atuação para esse controle dava-se de dois modos: por vezes, revisando a escrita depois de pronta e solicitando acréscimos ou alterações de letras e, em outros momentos, ditando letra a letra o que deveria ser escrito. O exemplo a seguir demonstra suas formas típicas de interação:

Jhoão; Agora sete pranchas. P, R, A com um til... Depois C, H, A.

Camila: (desconsidera o que o colega soletra e compõe a própria escrita, resultando em: 7RNXA).

Jhoão: Deixa eu ver... Sete... R, N, X, A? Não. É P.

Camila: (faz a alteração: apaga RN)

Jhoão: Põe o P no começo.

Camila: (faz como dita o colega).

Jhoão: R...prrr...

Camila: (faz como diz o colega)

Jhoão: Essa letra agora, ó (mostra o Ã de seu nome na lista de nomes da classe). O A com o til.

Camila: (escreve)

Jhoão: Pran... C, H e A e o S (vai ditando e controlando a produção da colega)

Camila: (escreve letra a letra seguindo o ditado de Jhoão).

Jhoão: (observa a produção). Vai... Agora ficou bom. 
Camila não rebatia as intervenções do colega e tendia a acatá-las sem questionamento, principalmente ao longo da primeira produção. Parecia reconhecer Jhoão realmente como um parceiro mais experiente quando o foco era a escrita convencional.

As intervenções de Jhoão acerca da grafia das palavras foram bastante sistemáticas e, na lista inicial, ele se mostrou até um tanto incomodado com o uso recorrente do $\mathrm{H}$ para os sons de G, por parte de Camila. Foi assim em "guarda-sol” e em "sunga”, por exemplo. Na segunda situação, ele disse a sua parceira: “é G. O G e o A é que faz ga, de gato. Não é o H. Esse a gente usa pra outras coisas”. O mesmo se pode dizer em relação da ausência de vogais junto a determinadas letras, como o C, usado de modo isolado para compor a sílaba “ca”.

É importante salientar essa informação dada por Jhoão como uma ação diferenciada que realiza enquanto usuário da linguagem escrita. Geraldi (2003) afirma que o escritor ou falante pode realizar ações de naturezas diversas nas situações de interlocução ${ }^{24}$. Dentre essas, destaca-se a ação exercida sobre a linguagem, que não têm um vínculo direto com os objetivos da comunicação pretendida, mas que se instaura no âmbito dos recursos lingüísticos. É como se o sujeito deixasse de lado, por alguns instantes, sua preocupação direta com a mensagem e o interlocutor e se dedicasse a refletir sobre a língua como objeto. Jhoão, como um escritor alfabético, realiza justamente uma "ação sobre a linguagem” quando chama a atenção de Camila para uma característica do princípio alfabético, no caso a relação entre um fonema e um grafema.

A versão final da primeira lista é apresentada, na seqüência, para ilustrar tais colocações.

\footnotetext{
${ }^{24}$ Esse autor diferencia três tipos de ações que os sujeitos exercem em relação à linguagem:

- $\quad$ ações que se fazem com a linguagem, atreladas aos objetivos pretendidos na situação particular de interlocução em que se encontra;

- $\quad$ ações da linguagem, quando características da própria fala ou da escrita em uma língua influenciam as interlocuções;

- $\quad$ ações sobre a linguagem (explicitada acima).
} 
Produção da lista 1

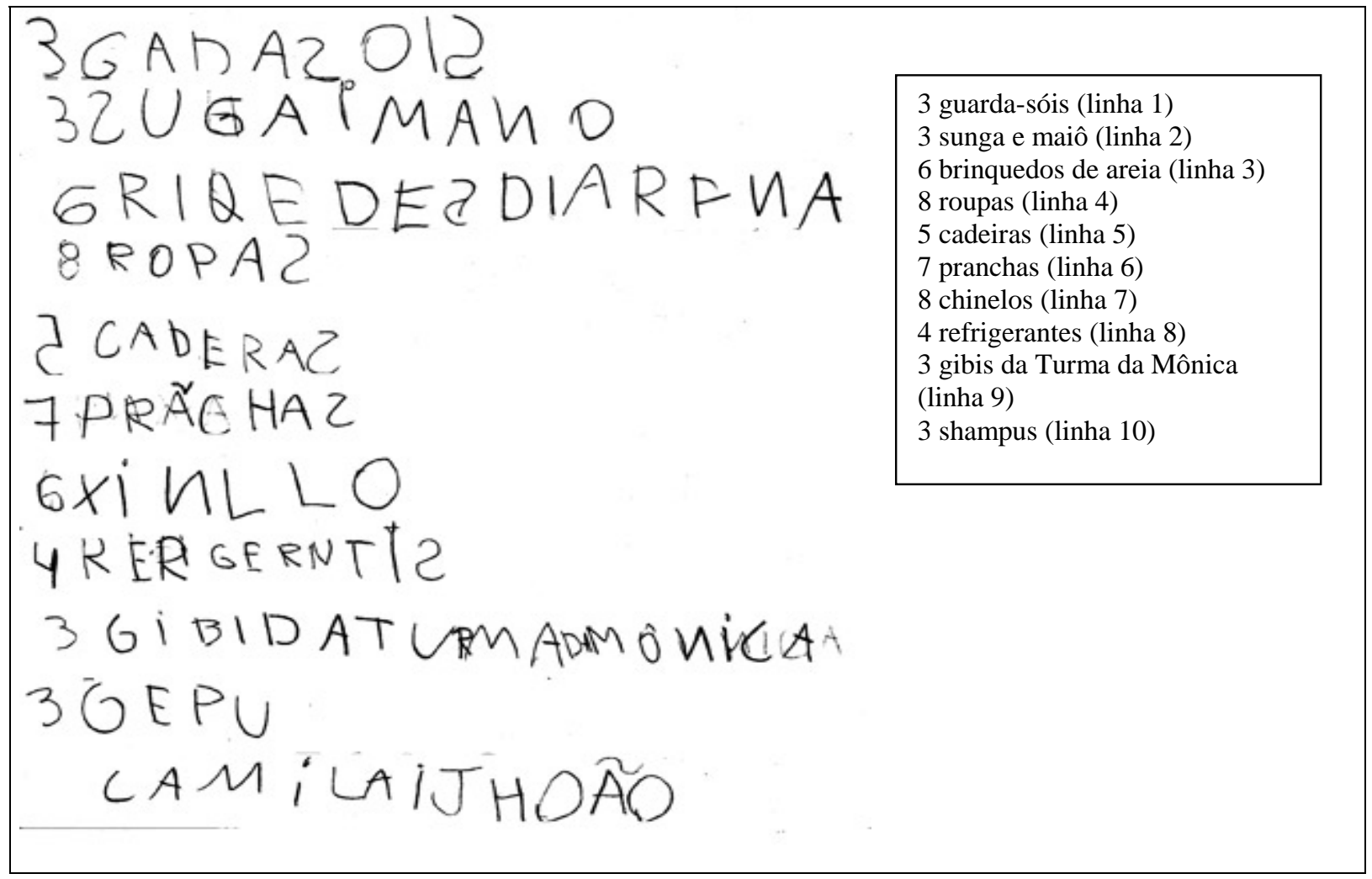

Levando em conta o interesse de Jhoão de corrigir o texto, é curioso constatar que os espelhamentos no uso das letras S e N não foram observados por ele, seja por representar ainda uma impossibilidade, seja por estar justamente focado em outro tipo de análise ao longo dessa produção: quantas e quais letras utilizar e não seus respectivos traçados.

Outro aspecto a ser salientado no que diz respeito à atuação de Camila nessa primeira produção diz respeito ao conteúdo do texto. Se ela iniciou a elaboração da lista sem participar ativamente das decisões que Jhoão tomava sobre o conteúdo, em um dado momento acabou discordando dos critérios de seu parceiro para eleger as quantidades de itens necessários (Jhoão havia resolvido eleger qualquer número entre cinco e oito). A partir dessa discordância, Camila começou a explicitar um interesse também pelo conteúdo e resolveu opinar sobre os próximos itens, e respectivas quantidades, sugerindo, entre outros itens, "seis chinelos" e "maiô". Porém, era evidente o tanto que ela se sentia desconfortável e pouco segura intervindo na tarefa do colega, cuidando para que suas colocações sobre o conteúdo nunca se dessem em forma de afirmações, mas via perguntas, para que soassem somente em tom de sugestões. 
Na produção da lista com a bagagem de frio, o uso do computador não foi um diferencial nas atuações dessas duas crianças. Jhoão continuou intervindo nas letras selecionadas por Camila, principalmente depois de concluída a grafia da palavra. Camila, por sua vez, mostrou-se mais atenta à necessidade de vogais junto às consoantes: o próprio “ca”, ainda que presente em seu nome, era grafado somente com C, como já foi citado, e tornou-se foco das correções de Jhoão na lista inicial. Nessa segunda produção, ela mesma resolvia a questão, empregando o C e o A corretamente em “cachecol” e “casaco”. Ela também parece ter compreendido e incorporado o papel exercido pelo colega, pois passou a chamar sua atenção sempre que concluía a escrita de um item, muitas vezes dizendo: “Olha como tá”; “Olha como eu escrevi"; "Vê se tá certo".

Em momento algum, Camila interrompeu sua escrita para consultar o colega e digitou com segurança optando pelas letras que julgava importantes. Dessa vez, tornou suas intervenções mais freqüentes, dando dicas em relação a itens possíveis - o que não mais aconteceu em forma de pergunta, mas em tom afirmativo - e permaneceu atenta às quantidades: sempre que Jhoão apresentava um número qualquer, Camila lhe lembrava que somente três pessoas fariam parte da viagem.

Abaixo, vê-se o resultado dessa segunda produção:

Produção da lista 2:

\section{ISCI 3CAGICOIS 3TOCA 3LUVAS 3CAZACO \\ 3BOTASDNEVI 3CAOSA 3CASINAICUECASI \\ 3MININASA 3MINISO 3MEINASBENICOTIS}

CAMILA E JHOÃO

3 esquis 3 cachecóis 3 tocas 3 luvas 3 casacos (linha 1 )

3 botas de neve 3 calças 3 calcinhas e cuecas (linha 2)

3 meninas 3 meninos 3 meias bem quentes (linha 3 )

O computador, nesse caso, assim como mencionado no capítulo 5, impossibilitou a traçado inverso de letras, aspecto que chegou a ser ressaltado por Camila em um dado momento dessa produção: “Nossa! Eu sempre pensei que o N não era desse jeito.” 
Na elaboração da primeira parlenda, Camila exibiu avanços ainda mais significativos, produzindo as palavras de forma quase convencional, principalmente com o cuidado de não deixar consoantes isoladas. Parecia também atuar mais confiante no seu próprio saber e, logo ao iniciar a produção, fez questão de comentar com Jhoão: "Vou fazer do meu melhor jeito pra ver se você tem menos coisas pra arrumar”.

Camila seguiu grafando a parlenda que dominava sem considerar, em alguns momentos, o ditado de Jhoão. Isso fez com que nem sempre ele pudesse retomar palavra a palavra e atuar de maneira sistemática em suas intervenções, pois quando pedia para ver o texto, a colega já havia escrito um verso inteiro ou até mais. Notável também foi o fato de que Camila passou a questionar certas orientações dadas pelo colega, diferentemente das produções anteriores. Mostrou-se, pela primeira vez, capaz de retomar sozinha determinadas grafias - e lê-las - e de antecipar as conseqüências que teriam as mudanças sugeridas pelo amigo. Os exemplos que se seguem ilustram esses importantes avanços:

Jhoão: Vai ter que escrever um, dois. Coloca: U, N, D, U, I e S.

Camila: (escreve os algarismos sem considerar a fala do colega que dita as letras correspondentes à grafia por extenso desses dois números)

Jhoão: (vê a escrita em algarismos). Deixa. Fica melhor assim.

$[\ldots]$

Jhoão: Agora, cinco, seis, feijão inglês.

Camila: (ignora a fala do colega e escreve a parlenda na versão que conhece, cinco, seis, enrolo vocês:

56IROLOVOSE)

Jhoão: O que está escrito aí?

Camila: Cinco, seis, enrolo vocês.

Jhoão: Mas eu falei outra coisa.

Camila: É que eu já tava escrevendo.

Jhoão: Tá, bomm. Agora, deixa eu ler. In-ro-lo-você. Tá. Eu conheço bem as letras! Ficou bom. Agora, sete, oito, comer...

Camila: (escreve silabando: 78COMEBICOTO. Não aguarda o ditado do restante do verso e segue

escrevendo-o)

Jhoão: Deixa eu ver... Sete, oito, come... Tem que ter um R aqui.

Camila: Mas vai ficar bir... É bis- coito e não bir.

Jhoão: Não. Tem que apagar o B o I, o C, o O, o T e o O e aí tem que colocar R. O R é para depois do E, pra ficar mer, comer.

Camila: (refaz, mas sem muita certeza)

Jhoão: Isso mesmo. Agora que você pôs o R, faz um novo B- I- C- O- T- O. Entendeu?... Eu não quero mudar biscoito. Porque você escreveu muito bem!

Camila: Eu entendi. (refaz exatamente como diz o colega) 
Nota-se que os esforços de Camila foram até reconhecidos por Jhoão, quando afirmou “você escreveu muito bem”. Camila nada disse nesse momento, além do “eu entendi”, porém, abriu um imenso sorriso diante do comentário de seu parceiro.

O processo de produção resultou no texto abaixo:

Produção da parlenda 1:

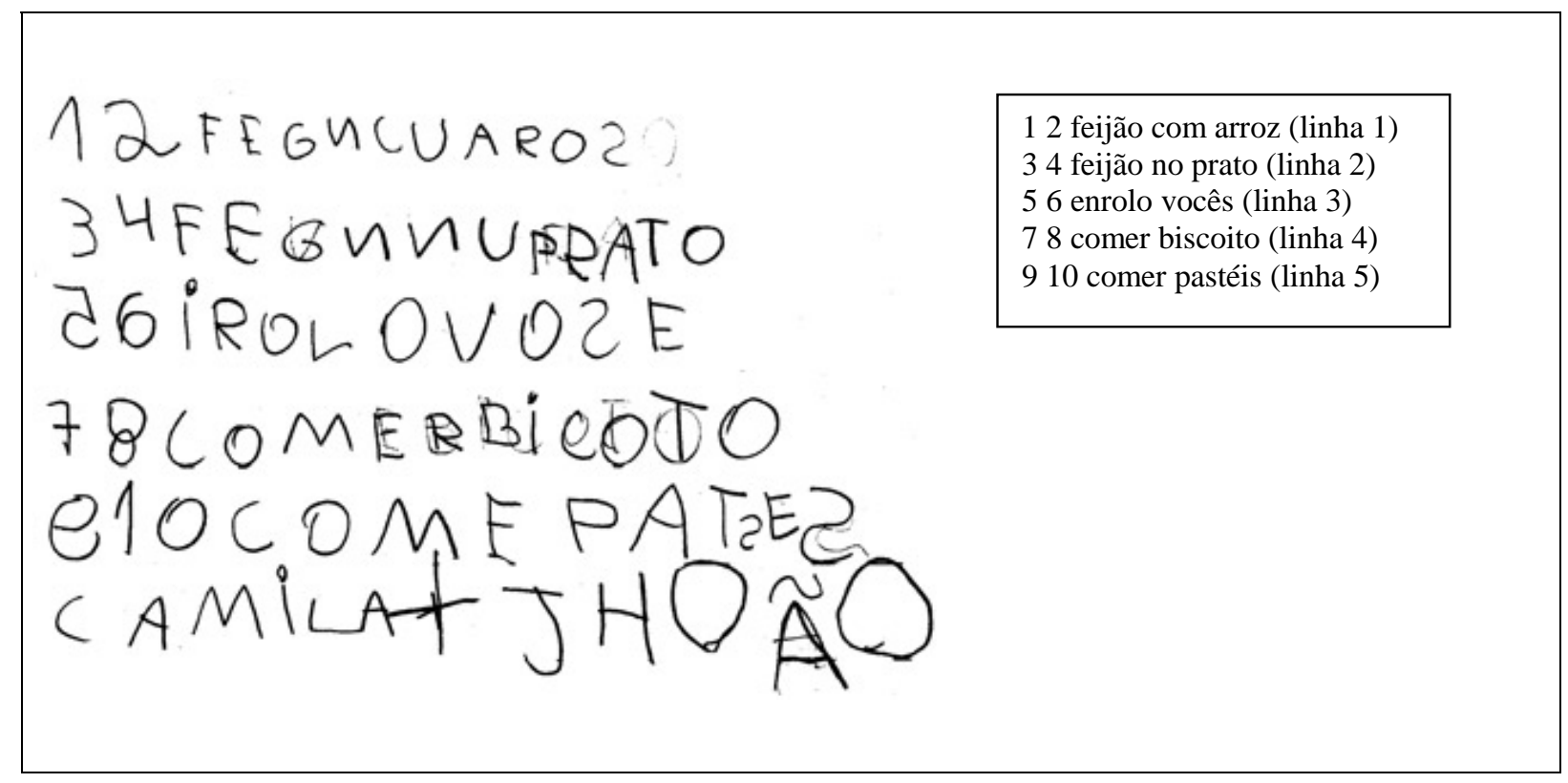

Na última situação de produção, Camila apresentou, de fato, uma escrita alfabética. Poucas foram as intervenções feitas pelo colega, que se limitou a validar as escritas da parceira, o que também resultou em uma tarefa executada a contento e rapidamente por essa dupla: precisaram de apenas 12 minutos para concluir o texto, um dos processos de construção textual de menor duração no montante dessa investigação. Em um desses raros momentos, Jhoão comentou a necessidade do uso do H para o som do “nh” em nossa língua. Camila não apenas compreendeu e reiterou a necessidade dessa letra como passou a utilizá-la sem ajuda para outras duas grafias, como se observa nos próximos exemplos:

Jhoão: Escreve a galinha...

Camila: (digita AHA. Olha para o monitor.) Opa! (apaga o $\mathrm{H}$ e o último A e digita GA, compondo AGA). Li...li (digita LI). Nhá... (digita NA).

Jhoão: (olhando para o monitor): A galina tá escrito.

Camila: (olhando para o monitor). É. Fica na. Eu sempre penso nisso porque o N e o A fazem o na, mas 
eu sei que precisa do $\mathrm{N}$ e do A pra fazer nhá também.

Jhoão: É porque precisa do H. Aqui (indica entre o $\mathrm{N}$ e o A).

Camila: Ah! O H faz nhá?

Jhoão: Se ficar junto do $\mathrm{N}$ e antes do A faz.

Camila: (refaz conforme indicação de Jhoão e compõe AGALINHA).

Jhoão: Agora do...

Camila: (segue silabando e digitando): Do (digita DO), vizi (VIZI), nho (NHO). Vi-zi-nho (faz a leitura apontando no monitor). Olha, Jhoão. Eu já entendi quando pôr o H.

Jhoão: É isso aí! Tá tudo certo! Você tá escrevendo mega bem!

$[\ldots]$

Camila: (segue digitando sem considerar o ditado de Jhoão, pois sabe o texto de memória). A-ma-re-li

(retoma sílaba a sílaba o que havia escrito), nho, nho (digita NHO novamente).

$\mathrm{P} 2 / \mathrm{D} 5$

Geraldi (2003, p. 20-25) sustenta a idéia de que existem "níveis distintos de reflexões” que um escritor pode realizar:

a) As atividades lingüísticas são aquelas que, praticadas nos processos interacionais, referem ao assunto em pauta, 'vão de si' , permitindo a progressão do assunto. [...]

b) As atividades epilingüísticas são aquelas que, também presentes nos processos interacionais, e neles detectáveis, resultam de uma reflexão que toma os próprios recursos expressivos como seu objeto. [...]

c) Atividades metalingüísticas são aquelas que tomam a linguagem como objeto não mais enquanto reflexão vinculada ao próprio processo interativo, mas conscientemente constroem uma metalinguagem sistemática com a qual falam sobre a língua. (grifos do autor)

Nesse sentido, a reflexão realizada por Camila tem um caráter bastante geral e a solução alfabética que dá para a escrita dessas palavras (“vizinho” e "amarelinho”) denota uma atividade metalingüística: lidando com uma informação de Jhoão, Camila compreendeu e pareceu ter se apropriado da grafia de um som mais complexo composto pelo dígrafo $\mathrm{NH}$, já que generaliza o uso dessas letras para outras situações em que são também necessárias.

É importante salientar ainda que Camila atuou de modo bastante seguro nessa produção e foram marcantes suas tentativas, com êxito, de retomada do que havia escrito.

Abaixo, tem-se o resultado desse último texto: 
Produção da parlenda $2^{25}$

\section{AGALINHADOVIZINHOBOTAOVOAMARLLINHO1234 5678910 CAMILAEJHOÃO}

As conquistas explicitadas por Camila ao longo das quatro situações configuradas nessa investigação implicaram não só um avanço na possibilidade de interação como também em uma maior aproximação à escrita convencional. Tomando-se como base apenas as produções da pesquisa, é possível relacionar a variedade de aspectos que, gradativamente, se constituíram em focos de preocupação ou de elaboração cognitiva por parte dessa criança: a relação entre fonemas e grafemas, a revisão da escrita, o ajustamento do texto ao seu propósito (a definição de quantidades para os itens da lista), a escrita do dígrafo LH e a necessidade de associação de vogais e consoantes. A última produção sequer necessita de uma transcrição, pois pode ser lida sem grandes dificuldades: à exceção da sílaba "re” em "amarelinho”, todo o restante do texto contém uma escrita alfabética. Não se pode assegurar que foram apenas os intercâmbios estabelecidos com Jhoão que permitiram tais conquistas, tampouco que foi sua participação como escriba nas quatro propostas o fator responsável por esses avanços. Efetivamente, foi todo um conjunto de diferentes experiências interativas com o universo da escrita, entre as quais as propostas nessa pesquisa, e com diversos sujeitos escritores, incluindo o próprio Jhoão, que favoreceu a ampliação de seus conhecimentos. Mesmo assim, as situações vividas no âmbito da pesquisa, transcritas no seu processo interlocutivo e registradas no seu produto final, puderam captar mecanismos de avanço que, na sua lógica microgenética, tão bem traduziram a "magia do desenvolvimento” na aprendizagem da escrita.

Outro caso - o de Beatriz e Luiz - foi selecionado, dentre os tantos observados, para ilustrar as diferentes e relevantes interações que precisam viver os aprendizes, assim como os diversos percursos que são trilhados no processo singular de construção de saberes.

\footnotetext{
${ }^{25}$ Assim como ocorreu com outras duplas, Camila e Jhoão omitiram a palavra "bota”, antecedendo cada algarismo. Esse aspecto foi abordado no capítulo 4.
} 


\subsection{O PERCURSO DE BEATRIZ}

Beatriz (3/4.10) e Luiz (3/5.5) também estabeleceram uma parceria diferenciada. Beatriz, como escriba, tomou todas as decisões relacionadas à grafia das palavras nas situações de produção no papel (lista 1 e parlenda 1). Seus textos já foram comentados no capítulo 5 (item 5.1.1, p. 109) e tomados como exemplos de produções pré-silábicas. Vale reiterar, apenas, que a menina elegia, de início, letras quaisquer para grafar as palavras, garantindo uma variedade e uma quantidade mínima de caracteres. Suas fontes de consulta foram a lista de nomes dos colegas da classe e o próprio teclado do computador.

No caso dessa parceria, é fundamental pontuar o papel exercido pelo computador. Luiz, ao contrário da dispersão e do pouco interesse que caracterizaram sua participação na elaboração dos textos no papel, tinha, diante do teclado e do monitor, uma postura diferenciada. A interação com o texto em si e com a colega escriba se ampliava bastante; ele, de fato, só apoiou a parceira nas duas produções em que esse recurso foi utilizado.

Também para Beatriz, a produção no computador trouxe um novo referencial, visto impedir o uso de outros símbolos que não os convencionais. Mesmo que elegesse quaisquer letras para grafar as palavras, essas pertenceriam ao nosso sistema de escrita e apareceriam com o traçado nítido e correto no monitor.

As interações observadas nessa parceria na elaboração da segunda lista e da segunda parlenda - ambas digitadas - propiciaram reflexões cada vez mais precisas sobre a relação entre a quantidade de sílabas e sua correspondência na representação do valor sonoro da escrita, aspecto que não ocupava as preocupações de Beatriz nas suas decisões individuais. Certamente essa já era uma questão sobre a qual Luiz refletia, talvez de modo não sistemático, mas que não fora capaz de explicitar e de partilhar com sua parceira na elaboração dos textos manuscritos.

A versão final da lista de viagem para a montanha servirá como base para a análise sobre os avanços que Beatriz apresenta: 
Produção da lista 2:

\section{DDGNIV2IUYOII4IZLSII4IBHJKLIUB4UYHK JMNLLIKJYGD04AASDFGUHJFDSWEERVBN 444C 4NBVFHJGUYTLUIZ BEATRIZH}

3 blusas de frio 2 cachecóis 4 luvas 4 sapatos de frio para esquiar 4 calças de frio (linha 1 ) máquina de fotos 04 mapas carro de andar na neve (na seqüência: HJFDSWEERVBN) 4 carros (linha 2) 4 carros Luiz Beatriz (linha 3)

A primeira vez que Luiz explicitou uma preocupação com o valor sonoro foi na grafia de “cachecol” (2IUYOII), na linha 1, conforme se pode observar no diálogo entre a dupla:

Beatriz: Onde é que eu tô, Luiz? Acho que já foi cachê...

Luiz: (olha rapidamente o monitor) Falta cóis, cóis. Acho que tem o O.

Beatriz: (procura e digita o O) cóis... cóis

Luiz: Tem I... is, is.

Beatriz: Dois “is" (digita II).

Luiz não opinou de forma contínua na escrita das palavras que ele mesmo ditava para a colega. Entretanto, quando consultado, demonstrou uma atenção aos sons, inclusive repetindo em voz alta a parte sonora que restava para compor “cachecóis”, e localizando representações que realmente fazem parte dessa grafia.

Nota-se que Luiz está começando a prestar atenção na questão do valor sonoro, mas as imposições e conseqüências desse critério são incompatíveis com outros conhecimentos que possui: como conciliar as representações dos sons com a exigência de escritas mais extensas do que as obtidas na produção silábica? Na formulação da segunda lista, por exemplo, quando novamente consultado pela dupla, antecipou que "luvas" teria duas letras, porém, não se conformou com uma grafia tão curta e continuou a ditar outras letras para compor a mesma palavra, produzindo 4IZLSII (quatro luvas).

Luiz ainda tentou controlar a quantidade na escrita de outro item. Ao ditar "calça de frio”, avisou Beatriz que deveria colocar apenas quatro letras, reiterando: “cal-ça-de-frio”, e contando nos dedos a quantidade de partes sonoras oralizadas. Sua sugestão foi acatada pela 
colega, que grafou UYHK e, em seguida, contou as letras dizendo para o colega: “tá certo porque eu coloquei quatro".

Mais adiante, foi a vez de Beatriz "experimentar”, como ela mesma disse, observar o valor sonoro:

Luiz: Escreve quatro carros.

Beatriz: Quatro carros (digita 444) Vou fazer assim que já tem muito quatro!.... Vou experimentar fazer igual você: ca, ca, ca. Eu já sei! É essa letra (aponta o C no teclado). É essa que faz o ca, do carro. (digita C). Acabei!... Dá certo pensar só nos pedaços!

Luiz: (olha o monitor) Não pode acabar com uma letra só!

Beatriz: Mas é assim carro. Pensa na sua cabeça: ca, ca.

Luiz: Eu acho que tem essa letra, mas não tem que ter mais também?

Beatriz: Tá, então vô escrever de novo. (digita um novo 4 e o computador muda automaticamente de linha. Beatriz observa essa mudança.) Ainda bem que mudou, porque assim separa do meu carro que já tá certo. (segue digitando várias letras para compor a nova grafia de “4 carros”).

$\mathrm{L} 2 / \mathrm{D} 3$

Essa “experimentação” por parte de Beatriz resultou na descoberta de um fonema que inicia a grafia da palavra “carro”. Também é interessante apontar que a menina estava bem atenta ao que lhe pareceu ser uma estratégia de Luiz para "eleger” as letras: repetir em voz alta partes sonoras. Mais do que isso, ela também “percebeu” o recorte silábico que costuma caracterizar esse momento conceitual.

Na produção da parlenda "Um dois, feijão com arroz”, entretanto, sem contar com o apoio de Luiz - que sequer fez menção de observar o que produzia a amiga - , e sem ter o computador como importante fonte de consulta e informação, Beatriz pautou-se apenas nos saberes que lhe soavam mais seguros para se decidir sobre as letras necessárias. O resultado desse texto pode ser visto no capítulo 5, item 5.1.1, conforme já citado, e novamente pode ser caracterizado como pré-silábico, dado o modo aleatório de escolher letras, tendo como marca a grande quantidade de símbolos e um cuidado ao variá-los interna e externamente.

Importante situar que no processo de apropriação da escrita, descrito do ponto de vista psicogenético, é possível perceber o que parece uma certa oscilação dos aprendizes, principalmente quando os conhecimentos que possuem soam incompatíveis com "novas descobertas”. Além disso, as tarefas de escrita (a atuação como escriba ou ditante, o tipo de texto e propósito que guia sua composição etc.) e as condições de produção, como as próprias parcerias 
ou mesmo os recursos disponíveis, também podem influenciar as decisões que tomam as crianças acerca da grafia das palavras.

Já na última produção, novamente tendo o computador à mão e a real parceria entre Luiz e Beatriz, a parlenda foi escrita sob um controle intenso de quantidade de letras e sistemáticas preocupações com o valor sonoro. Foi Luiz quem expôs inicialmente essas preocupações, como se pode verificar pelo exemplo, sendo seguido pela parceira:

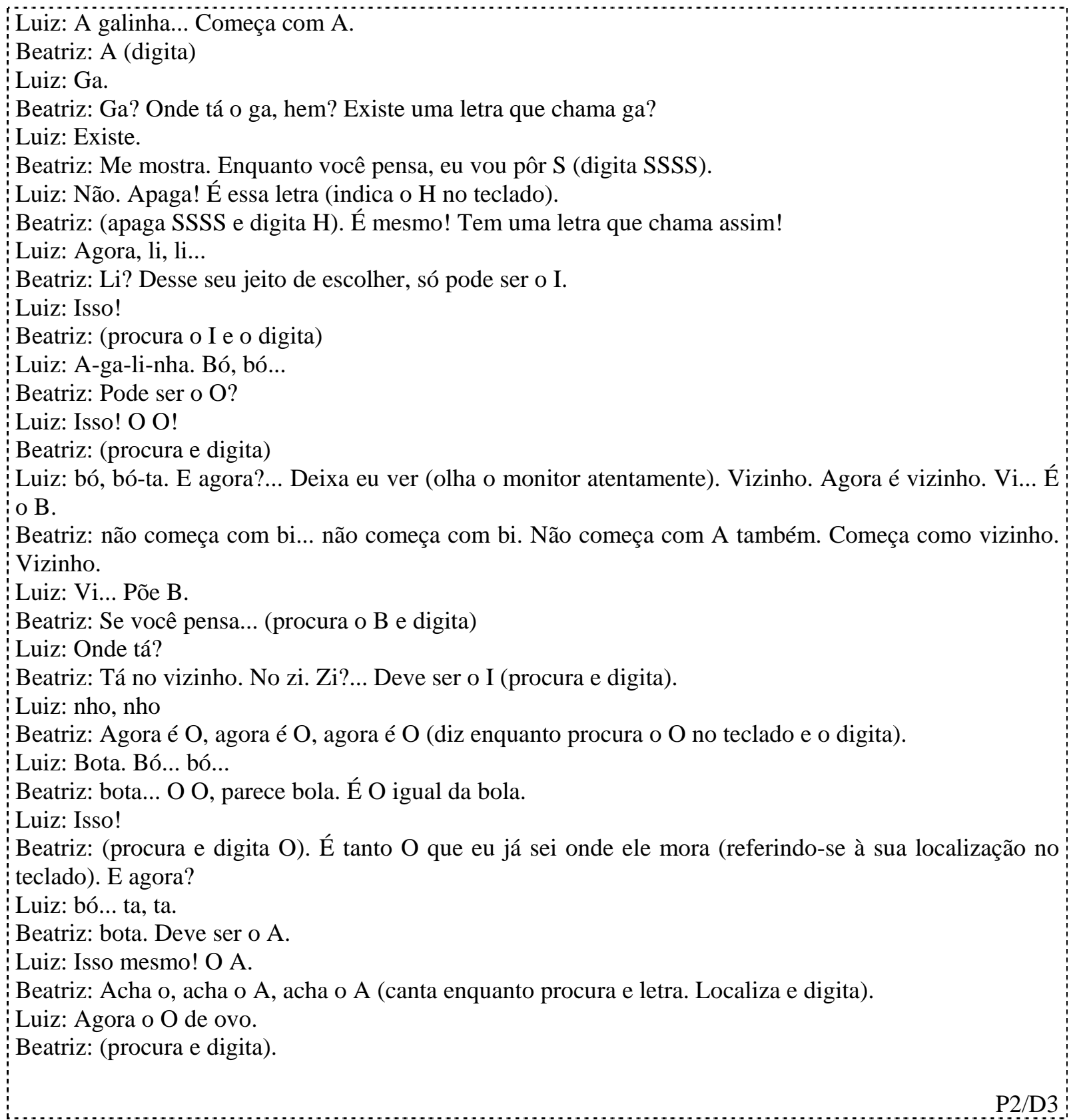


A escrita de "amarelinho", parte restante do texto, foi feita seguindo os mesmos critérios de análise. Assim como outras parcerias, Luiz e Beatriz omitiram a grafia de "bota" acompanhando a seqüência numérica que finaliza a parlenda, cuja versão final se pode observar aqui:

Produção da parlenda 2:

\section{AHIOBIOOAOAARIO12345678910BEATRIZLUIZ}

a-ga-linha-do-vizi-nho-bo-ta-ovo-a-ma-re-li-nho...

Beatriz finalizou a produção do texto e, tão logo digitou seu nome e o do colega, comentou: "gostei desse jeito de pensar pra escolher as letras. É muito boa essa invenção do Luiz, que agora também é minha, né?” Ainda sem ter clareza da dimensão do que diz e da complexidade da conquista que fez, pois se trata de um avanço conceitual, Beatriz iniciou uma apropriação do que julga ter sido ensinado pelo amigo. Novamente, não se pode afirmar que apenas observar e "experimentar" o "jeito" de Luiz foi o que bastou para que ela passasse a apresentar uma produção silábica. Tampouco se pode dizer que essa apropriação, tão recente, impedirá novas escritas mais próximas às versões pré-silábicas. Outras situações de produção e outras parcerias configuram-se igualmente como fundamentais interações dessa menina com a escrita, em seu processo de compreensão do sistema alfabético.

No caso de Beatriz e Luiz, também se pode afirmar que as tarefas vivenciadas no âmbito dessa investigação e os processos explicitados permitem observar mecanismos de avanço e diferentes focos de reflexão (os símbolos usados em nosso sistema de representação, a quantidade e variedade de símbolos para se configurar uma escrita, a relação fonema-grafema); ainda que singulares, demonstram não apenas "a magia do desenvolvimento” no percurso de apropriação da escrita, mas igualmente o caráter "vivo" que ganha esse objeto de conhecimento "nas mãos" desses pequenos escritores. 


\subsection{SE ALGO SE PODE CONCLUIR...}

Os percursos de Camila e Beatriz certamente se assemelham a muitos outros que podem ser observados em diferentes salas de aula, nas quais as crianças buscam, de modo intenso, apropriar-se da escrita alfabética. Não há, entretanto, processos idênticos de construção de conhecimentos simplesmente porque as experiências que vivenciam e as relações que são capazes de estabelecer possuem mesmo um caráter particular. É por essa razão que não se pode ter uma receita didática, com uma série de passos fixos, únicos e inflexíveis para os avanços conceituais de diferentes crianças.

No processo de ensino-aprendizagem, o que está em questão é todo um amplo e complexo conjunto de interações que precisam ser planejadas e propiciadas em sala de aula, para que pequenos passos possam ser dados pelos aprendizes. Não se pode atestar com exatidão que uma atividade pontual de escrita ou uma parceria específica ou mesmo uma ajuda do professor em um determinado momento garantiu a descoberta de novas características do sistema de escrita ou das diferentes formas de discurso que, com ele, se pode construir.

A tarefa da escola, no que se refere ao ensino da escrita - tomada como instrumento de comunicação, tal e qual existe socialmente -, e por conseqüência também a tarefa do professor ganham dimensões maiores e com graus de complexidade. Conhecer a fundo as contribuições teóricas, entre as quais as regularidades que permitem a construção de uma didática da Língua, é uma premissa do trabalho do professor. E é com a mesma relevância que esse professor deve conhecer seus alunos em seus percursos tão singulares. As intervenções que precisa realizar e as interações que precisa favorecer serão adequadas apenas na medida em que ele estiver apto a conciliar o conhecimento teórico com informações sobre cada um de seus aprendizes e sobre os pequenos passos que precisam dar a fim de que se tornem, gradativamente, escritores competentes.

Cabe reiterar a importância de interações não apenas com diferentes colegas e tarefas, mas com diferentes recursos de produção. O computador, nos processos de Beatriz e Luiz, por exemplo, atuou como rica fonte de informações e como um fator de motivação para que se estabelecesse uma parceria mais afinada, capaz de intercambiar reflexões e conhecimentos.

No capítulo que se segue e que encerra esta investigação, outras conclusões serão explicitadas considerando algumas implicações pedagógicas. Representa uma tentativa de refletir 
sobre a prática alfabetizadora e trazer referências para as opções didáticas que podem ser feitas com base na concepção construtivista de aprendizagem da escrita. 


\section{IMPLICAÇÕES PEDAGÓGICAS: CONCLUSÕES POSSÍVEIS}

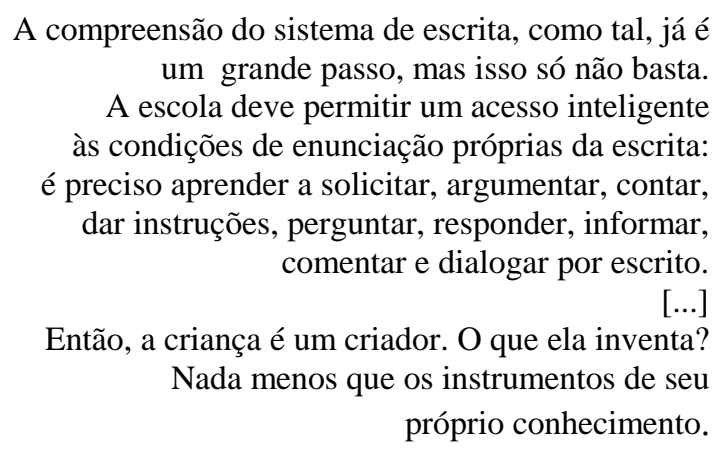

(FERREIRO, 2001b, p. 18 e 25)

A escrita é, desde sempre, um objeto de atenção e de indagações no universo infantil. Partindo dessa importante premissa, procurou-se investigar quais questões podem ser foco de reflexões por parte de pequenos aprendizes quando colocados à frente de tarefas de escrita similares às que vivem escritores experientes, nas quais conhecimentos sobre o sistema de representação, conhecimentos sobre as formas que esse sistema pode tomar - a depender dos propósitos sociais estabelecidos e procedimentos necessários à ação de compor um texto - sejam explicitados em simultaneidade. Em resposta às hipóteses da pesquisa levantadas inicialmente, as crianças demonstraram uma incrível - mas não surpreendente, se as concebemos como seres pensantes e "criadores"! - capacidade de resolver os diferentes problemas que a escrita lhes impôs, sejam atrelados ao discurso, aos aspectos enunciativos do texto, sejam atrelados à notação, ao sistema de representação, seus princípios e normas.

O que se evidenciou ao longo dos processos de produção textual das oito duplas foram tentativas de compreender o sistema de representação em sua totalidade e de se fazer compreender por meio dele. Esses aspectos não se colocavam em separado tampouco em uma ordem hierárquica para as crianças: elas não estavam voltadas primeiro para compreender a alfabeticidade do sistema e depois para usar esse sistema e se comunicar produzindo textos escritos; elas não se preocupavam somente com a escrita alfabética e depois com a necessidade de separar ou até de acentuar palavras; embora, em sua maioria, não soubessem escrever convencionalmente, não colocavam essa condição como empecilho para reflexões sobre a estrutura ou o conteúdo de um texto; muitas delas não sabiam ler alfabeticamente, mas 
reconheciam a importância da leitura para se retomar e avaliar a escrita; boa parte dessas crianças não se apropriou por completo do caráter fonético do sistema, mas reconhecia a possibilidade de comparar sonoramente palavras existentes em sua língua e buscar nelas apoio para produzir suas escritas; mesmo sem dominar a escrita alfabética e todos os gêneros textuais, tais crianças utilizaram o computador e usufruíram das facilidades que esse recurso lhes oferecia, facilidades que também puderam se configurar como objetos de reflexão (como a própria mudança automática de linha do WORD, a legibilidade que o texto ganhou na tela ou a presença de todos os símbolos usados em nosso sistema no teclado).

As análises feitas no decorrer dos capítulos anteriores permitem vislumbrar uma série de implicações pedagógicas, seja no intuito de reiterar postulados amplamente divulgados por outras investigações (inclusive por pesquisas básicas), seja para contribuir de forma direta para a revisão e reestruturação de intervenções didáticas.

Um primeiro aspecto que certamente pode ser reafirmado nesse momento diz respeito à inadequação dos métodos fechados para a alfabetização. Qualquer proposta dessa natureza que vise a "ensinar" a escrita por meio de passos estruturados de modo hierárquico, do mais simples para o mais complexo, e que julgue que todas as crianças podem aprender percorrendo os mesmos caminhos, coloca-se completamente incoerente com as demandas infantis e, mais do que isso, nega a própria heterogeneidade humana. Outro ponto problemático do trabalho com métodos é o tratamento dado à escrita, tida como um mero código a ser dominado pelos aprendizes. Como conseqüência dessa concepção, a escrita é ensinada com base em atividades sem vínculo algum com as situações sociais em que é utilizada: cópias de palavras, sílabas ou pseudo-palavras (o que é ainda mais incoerente dada a riqueza da nossa língua e todo o vocabulário que dela faz parte), repetição oral de sons etc. Conforme se identificou ao longo desta pesquisa, as crianças são absolutamente capazes de refletir sobre os mais variados aspectos da escrita e ampliar, assim, seus conhecimentos. São absolutamente capazes de aprender sobre o sistema de representação, entre outros aspectos, utilizando-o em contextos de produção textual, lidando com a tarefa de escrever tal e qual ocorre fora do âmbito escolar.

Se a meta da escola é inserir cada vez mais os aprendizes na cultura letrada, a adoção de métodos fechados - ou mesmo a retomada de debates acerca do melhor método -, considerando os indivíduos iguais e passivos perante o mundo e o ato de escrever uma tarefa de codificação, atua apenas no sentido de distanciar essa instituição de seus propósitos. Não se contribui para a 
formação de um usuário competente de sua língua quando o ensino se reduz a usos estritamente escolares, sem que se ensine a escrever verdadeiramente.

Nesse sentido, pode-se discorrer ainda sobre um segundo fator que tende a distanciar a escola da formação de escritores competentes: a distinção entre alfabetizar e letrar. Mesmo conferindo a justa importância às investigações sobre o letramento, que permitiram à escola um olhar mais amplo sobre as práticas sociais de escrita e leitura, do ponto de vista didático colocar novamente a alfabetização no status do ensino de uma técnica de codificação, em oposição ao letrar, em nada contribui para a compreensão desse objeto de conhecimento. A escrita não pode ser repartida: não há comunicação escrita sem um sistema de representação e não existe, nesse caso, um sistema de representação importante somente em si mesmo. A escrita não é um objeto de duas faces, mesmo que tomadas como “indissociáveis”. Se assim a entendemos, podemos vêla de modo similar a uma moeda, com suas duas faces indissociáveis (e assim o são porque somente juntas formam uma moeda). Usando essa metáfora, a escrita também seria composta por duas faces, mas, como na moeda, duas faces que correm em paralelo, mas que nunca se vêem, nunca se encontram.

A escrita é, e assim precisa ser entendida nos meios escolares, como um instrumento de comunicação formado por um sistema de representação, com características bastante específicas, que pode ganhar as mais diferentes formas em função da mensagem que se quer compor e de seus propósitos. Os gêneros textuais, utilizados nas diferentes práticas sociais de escrita e de leitura, constituem-se nessas diferentes formas que o sistema pode tomar nas mãos de um escritor.

Não há qualquer distinção possível em relação à escrita socialmente e não pode haver no interior da escola. Aprender a escrever significa efetivamente aprender a resolver problemas que as situações de comunicação impõem, o que só será possível quando as crianças estiverem diante de tarefas amplas e significativas de produção textual, que lhes possibilitem lidar com o sistema de representação, buscando compreendê-lo, e simultaneamente favorecer a apropriação das mais diversas formas nas quais esse sistema se apresenta. Por essa razão, não é possível distanciar por completo o momento da aprendizagem do momento de fazer uso da escrita.

A partir da análise dos dados feita nessa investigação, outros dois postulados podem ser reiterados aqui, e, pelo amplo tratamento que já lhes foi dado por pesquisadores de renome, entre os quais Piaget, Vygotsky e Ferreiro, serão apenas citados: 
- A concepção de criança como um ser pensante, capaz de analisar e refletir sobre o mundo a sua volta e trilhar caminhos singulares no seu processo de aprendizagem, criando, nas palavras de Ferreiro (2001b, p.25), “os instrumentos de seu próprio conhecimento”.

- O papel primordial da interação na aprendizagem afinal, uma vez que

todos os processos psicológicos que configuram o crescimento de uma pessoa [...] são fruto da interação constante que mantém com um meio ambiente culturalmente organizado (COLL, 1996, p. 40, grifos do autor).

Certamente esses postulados poderiam ser amplamente abordados nesta conclusão e outros poderiam ser citados, porém, interessa analisá-los de modo que possam colaborar para uma revisão e uma reconstrução da prática docente. Pela natureza didática da investigação aqui apresentada, é fundamental discorrer sobre implicações diretas na intervenção pedagógica.

Ao contrário de outras investigações que se supõem neutras, a presente pesquisa instaura-se justamente com sentido oposto: as situações de produção textual propostas são, de fato, situações desejáveis no interior das salas de aula; as parcerias organizadas entre as crianças estão entre aquelas que deveriam ser propostas nas situações escolares; as diferentes variáveis que configuraram a pesquisa (a escrita no papel e no computador; a produção de textos com diferentes características e propósitos) deveriam ser incorporadas pelas opções didáticas; os papéis exercidos pelos sujeitos (ditante, escriba, revisor) figuram entre os que devem realmente ser promovidos nas práticas de produção de textos na escola; o ambiente escolar no qual convivem as crianças observadas é planejado e organizado de acordo com os princípios fundamentais da concepção construtivista, exatamente o que se deseja para todas as instituições educativas. Enfim, a situação de pesquisa representa um exemplo didático, não para ser simplesmente reproduzido, mas para inspirar novas práticas calcadas no respeito ao sujeito aprendiz e na pluralidade da manifestação lingüística. Um exemplo didático cujos resultados aqui colhidos apenas atestam o imenso potencial infantil para refletir em prol da construção do conhecimento; um potencial inerente a todas as crianças, mas ainda sub-aproveitado pelas práticas de ensino.

A variedade e qualidade das reflexões explicitadas pelas crianças e as soluções dadas para os problemas que a tarefa de compor textos lhes trouxe demonstram que a escrita é, para 
esses pequenos usuários, um objeto vivo e do qual desejam se apropriar. Ainda que tão pouco experientes no mundo da comunicação escrita, essas crianças não refletem sobre ela em blocos estanques nem lidam primeiro com as questões que os adultos julgam mais simples, para depois lidar com aquelas um tantinho mais complexas, tampouco se ocupam primeiro dos problemas de um "código”. A escrita é, na concepção infantil, um objeto tão rico e tão único que suscita as mais diferentes questões. Questões que as crianças, uma vez motivadas e respeitadas, não temem enfrentar; mesmo que apresentem soluções distantes das convencionais, o desafio de escrever não é descartado ou rechaçado por elas. E, mais do que tudo, são capazes de se comunicar por escrito, de maneira efetiva, considerando os eventuais leitores e os propósitos pré-estabelecidos.

A partir dessas considerações, pode-se afirmar que um dos maiores princípios do ensino da escrita é a diversidade. Quando se reconhece a construção de conhecimentos como um processo individual, não se pode eleger um único e idêntico caminho a ser percorrido pelos aprendizes. A escola e seus professores não podem controlar, passo a passo, os processos singulares de aprendizagem e, portanto, não podem definir uma relação direta de causa e efeito entre a situação didática e os avanços dos alunos. É mesmo vivenciando um conjunto de experiências significativas com a escrita, com outros sujeitos aprendizes e sob intervenção do professor que as crianças poderão ampliar seus conhecimentos.

A diversidade é inerente à prática docente e, por conseqüência, inerente à alfabetização. Ferreiro (2002, p. 82), a respeito dessa temática, afirma que:

Sabemos que se alfabetiza melhor:

a) quando se permite a interpretação e produção de uma diversidade de textos (inclusive dos objetos sobre os quais o texto se realiza);

b) quando se estimulam diversos tipos de situações de interação com a língua escrita;

c) quando se enfrenta a diversidade de propósitos comunicativos e de situações funcionais vinculadas á escrita;

d) quando se reconhece a diversidade de problemas a serem enfrentados para produzir uma mensagem escrita (problemas de graficação, de organização espacial, de ortografia de palavras, de pontuação, de seleção e organização lexical, de organização textual...);

e) quando se criam espaços para que sejam assumidas diversas posições enunciativas ante o texto (autor, revisor, comentarista, avaliador, ator...), e

f) finalmente, quando se assume que a diversidade de experiências dos alunos permite enriquecer a interpretação de um texto [...]; quando a diversidade de níveis de conceituação da escrita permite gerar situações de intercâmbio, justificação e tomada de consciência que não entorpecem mas, pelo 
contrário, facilitam o processo; quando assumimos que as crianças pensam sobre a escrita (e nem todas pensam o mesmo ao mesmo tempo).

Não há definitivamente um método pronto a seguir capaz de abarcar a diversidade em todos esses aspectos. Do mesmo modo, não há uma infalível receita didática que permita lidar com a diversidade presente nos processos de aprendizagem. Há, no entanto, a necessidade de construção de um conjunto de princípios metodológicos que orientem as opções didáticas, que permitam aos professores planejar o trabalho com a escrita em sala de aula, definindo não apenas as situações a ser propostas, mas igualmente os papéis a ser exercidos pelas crianças e por eles também. Perante os desafios que serão propostos aos aprendizes, qual será o papel do professor? Atuará como observador de um pequeno grupo de alunos, acompanhará diretamente uma parceria, orientará, em especial, uma das crianças, realizando intervenções pontuais, e ao mesmo tempo planejará atividades significativas para o seu grupo-classe, redimensionando continuamente o conjunto do trabalho pedagógico a partir de um constante processo de (re)avaliação (dos alunos em particular; das parcerias; do grupo como um todo; das atividades, dos encaminhamentos e das intervenções pontuais propostos; das perspectivas de avanço na aprendizagem etc.).

A diversidade apontada por Ferreiro em seus múltiplos aspectos compõe certamente o núcleo desses princípios metodológicos. Princípios que podem ser reafirmados com base na análise das situações investigativas e dos processos pelos quais passaram as duplas de crianças na pesquisa aqui apresentada.

A diversidade de textos possibilita às crianças lidar com desafios diferentes. Na elaboração das listas e das parlendas, questões referentes à estrutura, ao conteúdo e à linguagem a ser utilizada fizeram parte das reflexões das crianças e foram resolvidas de forma a evidenciar esses dois gêneros textuais específicos. O mesmo se coloca quando, em sala de aula, o professor sugere a elaboração de bilhetes, cartas, e-mails, legendas informativas, breves narrativas literárias etc. Também é necessário que experiências leitoras e ouvintes sejam favorecidas em relação a esses textos, ampliando a familiaridade das crianças com a tarefa de interpretação e propiciando a observação de semelhanças e diferenças entre os gêneros que circulam socialmente.

Ao citar "objetos sobre os quais o texto se realiza”, Ferreiro aborda a questão dos recursos utilizados para se escrever. A escrita no papel e a escrita no computador trazem, como se pôde verificar na análise feita, desafios e informações diferentes para as crianças. Não se trata de 
eleger o que é melhor - escrever no papel ou no teclado de um computador -, mas de possibilitar situações em que esses recursos se coloquem como diferenciais tanto nas relações estabelecidas pelas crianças entre si, quanto com a própria língua escrita. A idéia, presente nesta investigação, de alterar a circunstância de produção e analisar cada qual à luz das interações estabelecidas estava associada não apenas ao tipo de texto, mas também ao oferecimento de diferentes recursos materiais tomados como favorecedores para a comunicação escrita no processo de aprendizagem inicial. Como situa Teberosky (In TEBEROSKY, GALLART, 2004, p. 153):

Do ponto de vista da alfabetização, não se deveria ensinar sem levar em conta as condições materiais de sua realização; do ponto de vista da aplicação das tecnologias da informação e da comunicação (TIC’s), não se deveria encarar apenas como uma questão técnica, fora dos requisitos cognitivos que permitem seu uso.

A análise sobre os processos vivenciados pelas parcerias e seus respectivos produtos, os textos, permitiu o reconhecimento de uma série de diferenças não só na postura das crianças perante a tarefa, como também nas ações sobre a própria língua escrita nas produções feitas no computador. Vale reiterar que não se toma, aqui, a tecnologia em si como responsável pela construção de conhecimentos ou como facilitadora das tarefas cognitivas que envolvem a produção escrita. $\mathrm{O}$ computador impõe às crianças novos desafios (como teclar e digitar e não mais grafar, como a presença de uma tecla que concretiza a ação de separar palavras etc.) e, assim, favorece determinados procedimentos, como a correção, sem aliviar o escritor da necessidade de refletir e de solucionar inúmeros problemas. Nas situações de produção oferecidas às crianças observadas, e mais especificamente nas decisões notacionais que tiveram que tomar, o computador não resolveu os confrontos e impasses que se estabeleceram. O uso do processador de textos atuou, de fato, como favorecedor de uma série de reflexões, não explicitadas nas produções manuscritas. (Cf. FERREIRO, 2002). Da mesma forma, as atividades realizadas no papel tiveram as suas especificidades e os seus desafios.

Planejar situações de produção de textos no papel e no computador significa possibilitar que as crianças, mais uma vez, tenham problemas diversos sobre os quais se debruçar, ampliando a oportunidade e análises, reflexões, observações e intercâmbios que precisam fazer para avançar na compreensão e apropriação da escrita.

A diversidade de interações com a escrita também se configura entre os princípios que guiam a intervenção pedagógica. Interações que se constituem nos atos de ler, mesmo sem que 
saibam decodificar; de ouvir leituras; de escrever textos diferentes e por razões diferentes; de escrever em parceria com colegas, intercambiando informações e procedimentos; de escrever ditando para o professor, podendo observar um modelo de escritor experiente e investindo em reflexões sobre as questões discursivas; de escrever sozinho, enfrentando toda a gama de problemas que a situação de escrita propicia e colocando em jogo saberes já construídos; de ler e de escrever os nomes dos colegas do grupo-classe, de refletir sobre eles acerca das características do sistema de representação e de refletir a partir deles para a composição de suas próprias escritas; de conhecer os textos em seus diferentes portadores, o que inclui o papel e o computador. A escrita é realmente um objeto social complexo e assim precisa ser conhecida e reconhecida em sala de aula para que os aprendizes se apropriem dela em todas as suas vertentes e recursos.

Dentre essas interações com a língua escrita, a pesquisa privilegiou também a interação social entre pares de crianças, por julgar que esse aspecto tende a ser pouco analisado em investigações. Como se verificou, a parceria por si só não se apresenta como uma situação significativa de intercâmbio e sequer se pode afirmar que a reunião de duas crianças para a tarefa de escrever favorecerá avanços. Aqui também a diversidade é um fator relevante. As parcerias se efetivarão de modos diferentes, dadas as características e demandas das crianças individualmente e os momentos que vivem em seus processos de aprendizagem. É por esse motivo que a diversidade de agrupamentos se coloca como outro princípio metodológico de destaque, afinal, parcerias diferenciadas oferecerão às crianças variados desafios. É fundamental que os professores assegurem a possibilidade de intercâmbios, tendo-a como uma premissa básica para as conquistas individuais.

Com relação à diversidade de propósitos comunicativos, esta investigação permitiu a análise de duas situações bastante distintas: a confecção de listas para ser retomadas por vários leitores (professor, colegas de classe e os pais) e parlendas para ser lidas pelos próprios autores aos demais alunos. Esse diferencial em relação aos propósitos e destinatários da escrita fez com que, por exemplo, a tarefa de revisão enquanto avaliação do texto estivesse mais presente nas composições das listas, já que teriam, de fato, outros leitores.

Sabe-se que quando propósitos comunicativos reais norteiam as tarefas de ler e escrever na escola, mais se aproxima as crianças de sua cultura letrada, visto que, nessas circunstâncias, a escrita se faz presente como no âmbito social. Reflexões sobre o conteúdo do texto, sobre sua 
pertinência em relação às condições estabelecidas, sobre a estrutura e a linguagem mais adequadas a depender do gênero eleito, sobre a melhor forma de grafar as palavras, sobre a necessidade de planejamento e revisão só se ampliam quando se tem que escrever para outros leitores. Essas situações precisam ocupar a maior parte do tempo didático destinado ao trabalho com a língua escrita - e também com a língua oral, se a entendemos obviamente como instrumento de comunicação. Primeiramente, porque é mesmo em situações comunicativas que as crianças se iniciam nas experiências com a língua, antes de seu ingresso na escola. E em segundo lugar, porque se a meta é que se tornem usuários cada vez mais competentes da língua escrita ou oral, o caminho é mesmo inseri-las em contextos efetivos de comunicação.

A escrita implicará sempre problemas de naturezas diversas (da ordem do discurso ou da notação) para seus usuários. Ainda que se trate de escritores bastante experientes, solucionar inúmeros problemas para que se estabeleça, pelos textos, uma comunicação eficiente é uma tarefa desafiadora. Se nos ativermos a esse fato, quanto antes a escola puder colocar as crianças lidando com esse rol de problemas, mais contribuirá para que sejam capazes de pensar sobre eles e tomar decisões acertadas. Não se está pedindo que aprendam, já na educação infantil, a solucionar adequadamente todas as questões referentes à produção textual. O desejável é que possam perceber, gradativamente, essa gama de aspectos a considerar e, também aos poucos, refletir sobre eles para tomar decisões. De início, decisões mais particulares e possivelmente mais distantes do que é convencional, entretanto cada vez mais se aproximando dos modelos, das soluções dadas por escritores já experientes. Quando a escola decide iniciar a alfabetização - que sequer se inicia na escola! -, pela aprendizagem do "código" - algo que a escrita não é! -, definindo que essa precisa ser priorizada ou antecedida a outras aprendizagens, limita-se a atuar para retardar ou impedir a formação de escritores e leitores.

Lidar com problemas impostos pela escrita significa ainda exercer papéis diferentes diante do texto, aspecto que também foi avaliado nesta pesquisa. As crianças tiveram a oportunidade de ditar, grafar, digitar, ler ou ouvir para revisar, comentar as soluções dadas pelo parceiro-escritor, comparar escritas etc. Essas diversas “posições ante o texto”, como se observou na análise dos processos interlocutivos de produção, colocam as crianças no papel de verdadeiras escritoras, ampliando suas interações com a escrita em sua totalidade.

Por fim, as diferenças conceituais nos processos de compreensão da escrita precisam ser reconhecidas não como um obstáculo para a intervenção didática, mas como um de seus mais 
importantes recursos. Os saberes que as crianças possuem favorecem intercâmbios e apóiam novas construções; como em um processo partilhado, as aprendizagens individuais são também fruto dessas interações entre os próprios aprendizes.

Em síntese, a presente pesquisa trouxe à tona algumas das reflexões e ações que pequenos usuários da escrita são capazes de realizar quando, a partir dos conhecimentos adquiridos, interagem com o sistema de representação e com suas formas de uso, quando as trocas entre as crianças são favorecidas e potencializadas e quando a tarefa de escrever tem mesmo um significado real.

Emilia Ferreiro, pesquisadora consagrada em se tratando de estudos sobre a aprendizagem da escrita, afirma que sua tarefa

[...] tem sido mostrar demonstrar que as crianças pensam a propósito da escrita, e que seu pensamento tem interesse, coerência, validez e extraordinário potencial educativo. Temos de escutá-las. Temos de ser capazes de escutá-las desde seus primeiros balbucios escritos (contemporâneos de seus primeiros desenhos). (FERREIRO, 2002, p. 36, grifo da autora)

De fato, não será focada no “como ensinar” que a escola conseguirá construir um novo percurso de práticas alfabetizadoras. Enquanto essa for sua única preocupação, reformulações didáticas terão apenas um caráter parcial - em algumas salas de aula, apenas - ou pontual algumas “atividades construtivistas” compondo a grade curricular. Se é necessário formar escritores e leitores competentes, usuários da língua na cultura tecnológica do século XXI, o caminho é “escutar” as crianças e não “ensiná-las a escrever”, favorecendo aprendizagens a partir do que pensam e das hipóteses que elaboram sobre o mundo letrado que as cerca. A distância entre como ensinam as escolas e como aprendem os alunos chega a ser, em alguns casos, gritante. E é esse o espaço que defensores de métodos fechados querem ocupar. O que fazem, entretanto, é deixar a distância entre ensino e aprendizagem ainda maior.

Deve-se compreender, definitivamente, que "não é o processo de aprendizagem que deve se adaptar ao de ensino, mas o processo de ensino é que tem de se adaptar ao de aprendizagem. Ou melhor: o processo de ensino deve dialogar com o de aprendizagem” (WEISZ; SANCHES, 2000, p. 65).

Os princípios metodológicos básicos já foram explicitados, as idéias infantis vêm sendo investigadas e analisadas, a escrita, enquanto objeto de conhecimento, tem sido também cada vez 
mais desvendada em pesquisas. Do ponto de vista didático, o que resta fazer é papel da escola e de seus professores: elaborar uma prática coerente a partir de tais princípios, preservando a escrita em suas características e funções e respeitando as tendências individuais e coletivas no processo de aprendizagem.

Para a construção de novas práticas de ensino, a formação inicial e a capacitação de professores colocam-se como fundamentais e necessitam, também, ser revistas e reconsideradas. Iniciativas nesse sentido devem obrigatoriamente levar em conta que um professor construtivista

[...] precisa construir conhecimentos de diferentes naturezas, que lhe permitam ter claros os seus objetos, selecionar conteúdos pertinentes, enxergar na produção de seus alunos o que já sabem e construir estratégias que os levem a conquistar outros patamares de conhecimento. A prática pedagógica é complexa e contextualizada, e portanto não é possível formular receitas prontas para serem aplicadas a qualquer grupo de alunos: o professor, diante de cada situação, precisará refletir, encontrar suas próprias soluções e tomar decisões relativas ao encaminhamento mais adequado, Um pouco como o antigo mestre-escola, ele precisará ser alguém com autonomia intelectual (WEISZ, 2000, p. 53-54)

Formadores e capacitadores devem colaborar para que os professores possam, de modo efetivo, colocar em prática os princípios do construtivismo tão presentes nos discursos educativos e em situações de capacitação, mas lamentavelmente distantes de boa parte das salas de aula brasileiras. Afinal, “o construtivismo como processo e a construção como necessidade histórica nunca estiveram tão juntos e foram tão necessários como agora” (FERREIRO, 2001b, p. 88). 


\section{REFERÊNCIAS}

ABAURRE, Maria Bernadete M., FIAD, Raquel S. e MAYRINK-SABINSON, Maria Laura T. Cenas de aquisição da escrita - o sujeito o e trabalho com o texto. Campinas: Mercado das Letras/ Associação de Leitura do Brasil - ALB, 1997.

ALENCAR, Eunice Soriano de (org.). Novas contribuições da Psicologia aos Processos de Ensino e Aprendizagem. São Paulo: Cortez, 1995.

BAKHTIN, Mikhail. Estética da criação verbal. São Paulo: Martins Fontes, 2003.

BELINTANTE, Claudemir. A guerra dos métodos. In: Revista Viver Mente\&Cérebro/ Emilia Ferreiro: a construção do conhecimento. Rio de Janeiro: Ediouro; São Paulo: SegmentoDuetto, v. 5, p. 62 - 67, 2005.

BENVENISTE, Claire B. La escritura, irreductible a um “código”. In: FERREIRO, Emilia (compiladora). Relaciones de (in) dependência entre oralidad y escritura. Barcelona: Gedisa Editorial, 2002.

BRAIT, Beth (org). Bakhtin: conceitos-chave. São Paulo: Contexto, 2005.

CAPOVILLA, Alessandra G. S. e CAPOVILLA, Fernando C. Alfabetização: método fônico. São Paulo: Memnon, 2002.

COLL, César. As contribuições da psicologia para a educação: teoria genética e aprendizagem escolar. In: LEITE, Luci Banks (org). Piaget e a Escola da Genebra. São Paulo: Cortez, 1987.

COLL, César e SOLÉ, Isabel Os professores e a concepção construtivista. In: COLL, Cesar. et. al. O construtivismo em sala de aula. São Paulo: Cortez, 1998. $5^{\text {a }}$ ed.

COLELLO, Silvia M. G. Linguagem escrita e escrita da linguagem: Emilia Ferreiro e Jean le Boulch: um confronto de teorias. 1990, 149p. Dissertação (Mestrado em Educação) USP. São Paulo.

COLELLO, Silvia M. G. Alfabetização em questão. São Paulo: Paz e Terra, 2004. 
COSTA, Sérgio Roberto. Interação e letramento escolar: uma (re)leitura à luz vygotskiana e bakhtiniana. Juiz de Fora: Ed. UFJF, 2000. Musa Editora, São Paulo.

FERREIRO, Emilia (org). Os filhos do analfabetismo. Porto Alegre: Artes Médicas, 1990.

$\frac{}{\text { tempo) }}$. Reflexões sobre alfabetização. São Paulo: Cortez, 1991. (Col. Polêmicas do nosso . Cultura, escrita e educação. Porto Alegre: Artmed, 2001a.

Atualidade de Jean Piaget. Porto Alegre: Artes Médicas, 2001b.

Passado e presente dos verbos ler e escrever. São Paulo: Cortez, 2002. (Col. Questões da nossa época)

Com todas as letras. São Paulo: Cortez, 2003.

Uma reflexão sobre a língua e a aprendizagem da língua escrita. Revista Pátio. Porto Alegre: Artmed, n.29, p., abr.2004.

. Alfabetização, letramento e construção de unidades lingüísticas. Palestra promovida pela Secretaria Estadual de Educação (Estado de São Paulo), março de 2005.

FERREIRO, Emilia; TEBEROSKY, Ana. Psicogênese da Língua Escrita. Porto Alegre: Artmed, 1985.

FERREIRO, Emilia; PALACIO, Margarita G. (orgs.) Os processos de leitura e escrita - novas perspectivas. Porto Alegre: Artes Médicas, 1987.

FERREIRO, Emilia et. al. Chapeuzinho Vermelho aprende a escrever. São Paulo: Ática, 1996.

FERREIRO, Emilia; TEBEROSKY, Ana. Psicogênese da Língua Escrita. Porto Alegre, Artmed,1999 (edição comemorativa). 
FERREIRO, Emilia; ALVARADO, Mônica. Four-and five-year old children writing with two digit numbers. In: Rivista di Psicolingüística Applicata, 2002, II, 3, p. 23 - 37.

FREITAS, Maria Teresa de Assunção. O pensamento de Vygotsky e Bakhtin no Brasil. Campinas: Papirus, 1994. (Col. Magistério, formação e trabalho pedagógico)

FREITAS, Maria Teresa de Assunção. Vygotsky e Bakhtin. Psicologia e educação: um intertexto. São Paulo: Ática, 2003.

GALABURRI, María Laura. La enseñanza del lenguaje escrito: un proceso de construcción. Buenos Aires: Ediciones Novedades Educativas, 2000.

GERALDI, João Wanderley. Linguagem e ensino: exercícios de militância e divulgação. Campinas: Mercado das Letras/ Associação de Leitura do Brasil - ALB, 1996.

Portos de Passagem. São Paulo: Martins Fontes, 1997.

KATO, Mary. No mundo da escrita: uma perspectiva psicolingüística. São Paulo: Ática, 1987.

KAUFMAN, Ana Maria e RODRIGUEZ, Maria Elena. Escola, leitura e produção de textos. Porto Alegre: Artmed, 1995.

KAUFMAN, Ana Maria (org). Letras y números - Alternativas didácticas para Jardín de Infantes y Primer Ciclo de la EGB. Buenos Aires: Santillana, 2000.

KAUFMAN, Ana María et. al. Alfabetização de crianças: construção e intercâmbio. Porto Alegre: Artmed, 2000 b, $7^{\mathrm{a}}$ ed.

KLEIMAN, Ângela B. (org.). Os significados do letramento: uma nova perspectiva sobre a prática social da escrita. Campinas: Mercado das Letras, 1995.

JOLY, Maria Cristina Rodrigues Azevedo. A tecnologia no ensino: implicações para a aprendizagem. São Paulo: Casa do Psicólogo, 2002. 
LANDSMANN, Liliana Tolchinsky. Aprendizagem da Linguagem Escrita: processos evolutivos e implicações didáticas. São Paulo: Ática, 1995.

LEITE, Sergio A. S. Notas sobre o processo de alfabetização escolar. In: Alfabetização e letramento. Campinas: Komedi: Arte Escrita, 2001.

LERNER, Delia. Ler e escrever na escola - o real, o possível e o necessário. Porto Alegre: Artmed, 2002.

LURIA, Alexander Romanovich; VYGOTSKY, Lev Semenovich; LEONTIEV, Alexis. Linguagem, desenvolvimento e aprendizagem. São Paulo: Ícone/Edusp, 1991.

MORTATTI, Maria do Rosário Longo. Os sentidos da alfabetização (São Paulo/1876-1994). São Paulo: UNESP, 2000.

OLIVEIRA, Marta Kohl de. Pensar a educação: contribuições de Vygotsky. In: CASTORINA, José Antonio et al. Piaget-Vygotsky: novas contribuições para o debate. São Paulo: Ática, 1995.

Scipione, 1997.

Vygotsky: Aprendizado e desenvolvimento um processo sócio-histórico. São Paulo, PATTO, Maria Helena Souza. A produção do fracasso escolar: histórias de submissão e rebeldia. São Paulo: Casa do Psicólogo, 1999.

PIAGET, Jean. Para onde vai a educação?. Rio de Janeiro: Livraria José Olympio Editora, 1978. $6^{\mathrm{a}}$ ed.

Seis estudos de Psicologia. Rio de Janeiro: Forense Universitária, 1991.

. O possível, o impossível e o necessário (As pesquisas em andamento ou projetadas no Centro Internacional de Epistemologia Genética). In: LEITE, Luci Banks (org). Piaget e a Escola da Genebra. São Paulo: Cortez, 1987.

POPPOVIC, Ana Maria. Atitudes e cognição do marginalizado cultural. In: Revista Brasileira de Estudos Pedagógicos. Rio de Janeiro, 57 (126):244-254, abril/junho, 1972. 
POPPOVIC, Ana Maria e MORAES, Genny Golubi de. Prontidão para a alfabetização: Programa para o desenvolvimento de funções específicas. Teoria e Prática. São Paulo: Vetor, 1966.

POSTNER, Michael I. e RAICHLE, Marcus. Imagens da mente. Portugal: Porto Editora, 2001.

POZO, Juan Ignácio. A solução de problemas. Porto Alegre: Artmed, 1998.

RIBEIRO, Vera Masagão. Por mais e melhores leitores: uma introdução. In: RIBEIRO, Vera Masagão (org). Letramento no Brasil. São Paulo: Global, 2003.

ROCHA, Gladys e VAL, Maria da Graça Costa (orgs). Reflexões sobre as práticas escolares de produção de texto - o sujeito-autor. Belo Horizonte: Autêntica/CEALE/FaE/UFMG, 2003.

ROJO, Roxane (org). Alfabetização e letramento: perspectivas lingüísticas. Campinas: Mercado das Letras, 1998.

SECRETARIA DE EDUCACIÓN DE LA CIUDAD DE BUENOS AIRES. Atualización Curricular - E.G.B.Primer Ciclo - Lengua - documento de trabajo no 2. 1996.

SECRETARIA DE EDUCACIÓN DE LA CIUDAD DE BUENOS AIRES. Pre diseño curricular para Educación Inicial - Niños de 4 y 5 años. 1999.

SEMEGHINI-SIQUEIRA, Idméa. A questão da leitura no âmbito da Ciência Cognitiva.: memória e consciência. Coleção Documentos. Série Ciência Cognitiva. São Paulo: USP-IEA, 1994, v. 20, p. 168-178

SILVA, Elisabeth Ramos da e LOPES-ROSSI, Maria Aparecida Garcia (orgs). Caminhos para a construção da prática docente. Taubaté-SP: Cabral Editora e Livraria Universitária, 2003.

SINCLAIR, Hermine (org). A produção de notações na criança: linguagem, número, ritmos e melodias. São Paulo: Cortez/Autores Associados, 1990. (Col. Educação Contemporânea) 
SMOLKA, Ana Luiza B. E GÓES, Maria Cecília R. de (orgs). A linguagem e o outro no espaço escolar - Vygotsky e a construção do conhecimento.Campinas: Papirus, 2003 (Col. Magistério; Formação e Trabalho pedagógico).

SOARES, Magda. Alfabetização no Brasil: o estado do conhecimento. Brasília: Reduc, 1989.

Aprender a escrever, ensinar a escrever. In: ZACCUR, Edwiges (org). A magia da Linguagem. Rio de Janeiro: DP\&A: SEPE, 1999.

. Letramento e escolarização. In: RIBEIRO, Vera Masagão (org). Letramento no Brasil. São Paulo: Global, 2003.

TAILLE, Yves de la. O erro na perspectiva piagetiana. In: AQUINO, Júlio Groppa. Erro e fracasso na escola- alternativas teóricas e práticas. São Paulo: Summus, 1997.

TEBEROSKY, Ana. Aprendendo a escrever - Perspectivas psicológicas e implicações educacionais. São Paulo: Ática, 1997.

Psicopedagogia da Linguagem escrita. São Paulo: Trajetória Cultural; Campinas: Editora da UNICAMP, 1990.

TEBEROSKY, Ana. e CARDOSO, Beatriz. Reflexões sobre o ensino da leitura e da escrita. São Paulo: Trajetória Cultura; Campinas: Editora da Universidade Estadual de Campinas, 1990.

TEBEROSKY, Ana e COLOMER, Teresa. Aprender a ler e a escrever: uma proposta construtivista. Porto Alegre: Artmed, 2003.

TEBEROSKY, Ana e GALLART, Marta Soler [et al]. Contextos de alfabetização inicial. Porto Alegre: Artmed, 2004.

TEBEROSKY, Ana e TOLCHINSKY, Liliana (orgs). Além da alfabetização. São Paulo: Ática, 1996.

TFOUNI, Leda Verdiani. Letramento e alfabetização. São Paulo: Cortez, 1995. 
VERNON, Sofia Alejandra. El processo de construccion de la correspondencia sonora em la escritura (en la transicion entre los periodos pre-silabicos y el silabico), 1991, 90 p. Dissertação (Maestro en Ciencias, especialidad en Educación) Departamento de Investigaciones Educativas del Centro de Investigación y Estudios Avanzados del Instituo Politecnico Nacional, Mexico, D.F.

VERNON, Sofia Alejandra e FERREIRO, Emilia. Writing development: a neglected variable in the consideration of phonological awareness. In: Harvard Educational Review. 1999, 69, 4, 395-415.

VYGOTSKY, Lev Semyonovich. A formação social da mente. São Paulo: Martins Fontes, 1991.

Pensamento e Linguagem. Lisboa: Edições Antídoto, 1979.

WEISZ, Telma. As Contribuições da Psicogênese da Língua Escrita e Algumas Reflexões sobre a Prática Educativa de Alfabetização. In: São Paulo (Estado) Secretaria da Educação. Coordenadoria de Estudos e Normas Pedagógicas. Ciclo Básico em Jornada Única: uma Nova Concepção de Trabalho Pedagógico. São Paulo FDE, 1988.

WEISZ, Telma e SANCHES, Ana. O diálogo entre o ensino e a aprendizagem. São Paulo: Ática, 2000.

ZABALA, Antoni. A prática educativa: como ensinar. Porto Alegre: Artmed, 1998.

ZACCUR, Edwiges (org). A magia da linguagem. Rio de Janeiro: DP\&A: SEPE, 1999

ZACHARIAS, Vera Lúcia Câmara F. Um mundo de leitores. In: Revista Viver Mente\&Cérebro/ Emilia Ferreiro: a construção do conhecimento. Rio de Janeiro: Ediouro; São Paulo: Segmento-Duetto, v. 5 (suplemento especial: movimentos de alfabetização), p. 62 67, 2005. 
ANEXO 